\title{
Mudança, consternação
}

\section{Um estudo sobre o discurso no primeiro "rock argentino"}

Tese apresentada à Faculdade de Filosofia, Letras e Ciências Humanas da Universidade de São Paulo, conforme Edital FFLCH 001/2017, para inscrição em Concurso de Títulos e Provas para obtenção do título de Livre-Docente, no Departamento de Letras Modernas, Área de Língua Espanhola e Literaturas Espanhola e Hispano-Americana, disciplina de Língua Espanhola.

São Paulo

2017 
FANJUL. A.P. Mudança, consternação. Um estudo sobre o discurso no primeiro "rock argentino". Tese apresentada à Faculdade de Filosofia, Letras e Ciências Humanas da Universidade de São Paulo, conforme Edital FFLCH 001/2017, para inscrição em Concurso de Títulos e Provas para obtenção do título de Livre-Docente, no Departamento de Letras Modernas, Área de Língua Espanhola e Literaturas Espanhola e Hispano-Americana, disciplina de Língua Espanhola.

Aprovado em:

Banca Examinadora

Prof (a) Dr (a) Instituição:

Julgamento:

Assinatura:

Prof (a) Dr (a) Instituição:

Julgamento:

Assinatura:

Prof (a) Dr (a) Instituição:

Julgamento:

Assinatura:

Prof (a) Dr (a) Instituição:

Julgamento:

Assinatura:

Prof (a) Dr (a) Instituição:

Julgamento:

Assinatura: 
A mi hijo, Fernando Javier Fanjul, "un hombre que espera el alba", siempre confiable y buscando los lugares en su tiempo. 


\section{AGRADECIMENTOS}

A todas e todos os meus colegas da área de Língua Espanhola e Literaturas Espanhola e Hispano-Americana da FFLCH-USP, por muitos motivos. Por tudo que aprendi junto del@s em dezesseis anos de trabalho, pelo apoio e estímulo constantes, e por fazerem do nosso espaço um bastião de pensamento crítico, nesta fase operacional e empobrecedora que vive a Universidade.

Aos muitos colegas da USP com quem tentamos construir, nestes anos, espaços de defesa do caráter público da universidade, produzindo reflexões, divulgando estudos, agindo nos colegiados e na arena pública. Com muitos deles desenvolvi amizades sólidas, e neles abraço tod@s que lutam pela recuperação da democracia.

Aos mestres de quem tanto aprendi, e que não caberiam nesta página.

Aos amigos queridos, que também não caberiam, mas me sabem perto.

A Neide Maia González, por ser parte de todos esses lugares que mencionei, pelo conselho e atenção em todas as horas, e pelo carinho tão familiar e especial.

A mi padre, Roberto, a mi hermana, Patricia Irene, a mi sobrina, Marina, a Pastora, y a mi madre, Alba (en la memoria). Nuevamente, por supuesto, a Fernando.

A Neide Elias, pelos anos compartilhados, por tudo que houve neles, e que sempre lembro com carinho e gratidão.

A un amigo especialísimo, Alejandro Gargiulo, además de las décadas de amistad incondicional, que tanto han facilitado mis recorridos porteños, por las grandes ayudas de su memoria del rock, y de su acervo, que parece inmensurable.

A Lucas Jannoni Soares, pela compreensão, as vivências e o encontro.

A todos que, de alguma maneira, colaboraram na minha pesquisa. Ao CNPq pelo apoio de fomento. A Claudio Díaz y Lucio Carnicer, por los muchos intercambios de datos y opiniones, con su actitud tan rockera de compartir. A los empleados del Fondo Nacional de las Artes.A tod@s, muchas gracias! 


\section{RESUMO}

FANJUL. A.P. Mudança, consternação. Um estudo sobre o discurso no primeiro "rock argentino". Tese apresentada à Faculdade de Filosofia, Letras e Ciências Humanas da Universidade de São Paulo, conforme Edital FFLCH 001/2017, para inscrição em Concurso de Títulos e Provas visando a obtenção do título de Livre-Docente para o Departamento de Letras Modernas, Área de Língua Espanhola e Literaturas Espanhola e Hispano-Americana, disciplina de Língua Espanhola.

Esta tese tem como propósito um estudo da regularização discursiva no denominado "rock argentino", abrangendo de modo integral os primeiros períodos da delimitação e paulatina consolidação desse campo. A partir do estudo das polêmicas nos campos cultural, político e intelectual na Argentina da época, bem como da observação do corpus de composições musicais estabelecido, formulamos, como eixos iniciais para a indagação discursiva, a representação dos percursos de vida, dos deslocamentos dos seres e da atividade artística, bem como a formulação de modelos e de contra-modelos. Na tentativa de integrar, no estudo da regularização, aquilo que ela deixa fora ou nas fronteiras do dizível, a abordagem do corpus foi precedida por uma reflexão sobre tópicos que não se manifestam nele, apesar da sua proximidade com objetos que aparecem profusamente. Depois, ao longo de vários percursos pelo corpus, hipotetizamos, descrevemos e explicamos, com base nas análises, uma regularização que atravessa predominantemente o campo estudado, e também um processo de desregularização parcial. Percebemos préconstruidos em torno da necessidade de mudança de alcance social, mas com o indivíduo como espaço principal de realização, e um atravessamento contraditório de diversas posições de sujeito, em filiação com construtos ideológicos em pugna, na época, em torno da possibilidade do homem de agir e de transformar os modos e as condições de vida e de produção. Tanto essa regularização quanto sua desregularização parcial são postuladas a partir da repetibilidade de configurações que envolvem as instâncias de pessoa, determinados objetos de discurso e cenografias enunciativas. Foram mobilizadas categorias de análise que tentam dar conta dessas dimensões, e foi incorporada aos procedimentos de análise uma observação de diversos aspectos da dimensão sonora na música, e da performance na interpretação vocal. A análise se estendeu também a outros materiais de circulação no campo, como encartes de discos e filmagens, bem como a produções poéticas não musicais. O estudo envolveu, ainda, relações de aproximações e distanciamento entre o denominado "rock argentino" e campos anteriores e contemporâneos da música argentina de tradição popular, tanto no plano da materialidade discursiva quanto nos papéis que eles cumpriram na conflituosidade da formação social. O desenvolvimento da análise foi dando lugar, nos diferentes capítulos, a conclusões sobre a especificidade dos processos de regularização e desregularização em relação a como foram discursivizadas as práticas de aspiração transformadora que ocuparam a cena política e cultural argentina nas décadas de 1960 e 1970, bem como a crescente violência de Estado no período. A partir dessas observações, próprias de uma abordagem materialista do discurso, a pesquisa realizada se constitui como exploração inovadora acerca do rock argentino. O trabalho também propiciou reflexões teórico-metodológicas 
em torno dos agrupamentos do discurso, e de possíveis relações entre configurações enunciativas e regularização,

Palavras-chave: rock argentino -regularização discursiva - cultura argentina do século $\mathrm{XX}$ - análise materialista do discurso

\section{ABSTRACT \\ FANJUL. A.P. Change, consternation. A study on the discourse in the first "Argentine rock".}

This thesis is aimed at studying the discursive regularization about the so-called "Argentine rock", comprehensively comprising its first delimitation periods and the gradual consolidation of this field. Based on the study about the controversies in the cultural, political and intellectual fields in Argentina at that time, as well as the observations of the musical composition corpus which was established, we have formulated, as initial guidelines for the discursive questioning, the representation of the life paths, of the movements of the beings and of the artistic creative activity, as well as the formulation of models and countermodels. In an attempt to integrate in the regularization study what is left out or what is located in the borders of the speakable, the corpus approach was preceded by a reflection on some topics which are not manifested in the corpus, in spite of their proximity with objects that profusely appear in it. Then, along many paths throughout the corpus, we have hypothesized, described and explained, based on analyses, a regularization which predominantly permeates the studied field, and also a partial deregularization process. We have noticed some implicit ideas against the necessity of change in social impact, but the individual is considered as the main space for this achievement, with contradictory conflicts among different subject positions, in affiliation with ideological concepts at the time, about the possibility for humans to act and transform their life conditions and means of production. Both this regularization and its partial deregularization are conceived according to the repeatability of configurations which involve one's particularities, specific discourse objects and enunciative scenographies. Some analysis categories were used in an attempt to deal with these dimensions, and observations of different aspects of sound dimension in music and of performance in vocal interpretation were incorporated into the analysis. It also comprised other materials circulating in the field, such as LP record album notes and video shootings, as well as nonmusical poetical productions. The study also involved approaching and distancing relations between the so-called "Argentine rock" and previous and contemporary fields of popular tradition in Argentine music, both in the discursive materiality plan and in the roles which they played in the conflict level of the social formation. The analysis development gave way, along the chapters, to conclusions about the specificity of the regularization and deregularization processes regarding how 
the tranformation-aspiring practices which occupied the political and cultural Argentine scene were discursively processed, as well as the escalading State violence at the time. Considering these observations, typical in a materialistic approach about discourse, the study is also constituted as innovative exploration about the Argentine rock. It also provides theoretical and methodological reflections about discourse clusters, and about possible relations between enunciative configurations and regularization.

Keywords: Argentine rock - discursive regularization - Argentine culture in the 20th century - materialistic discourse analysis

\section{RESUMEN}

\section{FANJUL. A.P. Cambio, consternación. Un estudio sobre el discurso en el primer} "rock argentino".

Esta tesis tiene como propósito un estudio de la regularización discursiva en el llamado "rock argentino", abarcando de modo integral los primeros períodos de la delimitación y paulatina consolidación de ese campo. A partir del estudio de las polémicas en los campos cultural, político e intelectual en la Argentina de la época, así como de la observación del corpus de composiciones musicales establecido, formulamos, como ejes iniciales para la indagación discursiva, la representación de los recorridos de vida, de los desplazamientos de los seres y de la actividad artística, así como la formulación de modelos y de contramodelos. En un intento de integrar, en el estudio de la regularización, lo que ese proceso deja afuera o en las fronteras de lo decible, hicimos preceder el abordaje del corpus por una reflexión sobre tópicos que no se manifiestan en él, a pesar de su cercanía a objetos que aparecen profusamente. Después, a lo largo de varios recorridos por el corpus, hipotetizamos, describimos y explicamos, en base a los análisis, una regularización que atraviesa predominantemente el campo estudiado, y también un proceso de desregularización parcial. Percibimos preconstruidos alrededor de la necesidad de un cambio de alcance social, pero con el individuo como espacio principal de realización, y un atravesado contradictorio de diversas posiciones de sujeto, en filiación con constructos ideológicos en pugna, en esa época, alrededor de la posibilidad de que el hombre actúe y transforme los modos y condiciones de vida y de producción. Tanto esa regularización como su desregularización parcial se postulan a partir de la repetibilidad de configuraciones que involucran las instancias de persona, determinados objetos de discurso y escenografías enunciativas. Movilizamos categorías de análisis que intentan dar cuenta de esas dimensiones, e incorporamos a los procedimientos de análisis una observación de diversos aspectos de la dimensión sonora en la música, y de la performance en la interpretación vocal. El análisis se extendió también a otros materiales que circulaban en el campo del rock argentino, como tapas y sobres de discos, filmaciones, como también producciones poéticas no musicales. El estudio incluyó, además, relaciones de acercamiento y de alejamiento entre el denominado "rock argentino" y campos anteriores o contemporáneos de la música argentina de tradición 
popular, tanto en el plano de la materialidad discursiva como en los papeles que esos géneros cumplieron en la conflictividad de la formación social. El desarrollo del análisis fue dando lugar, en los diferentes capítulos, a conclusiones sobre la especificidad de los procesos de regularización y desregularización en relación a cómo se discursivizaron las prácticas de aspiración transformadora que ocuparon la escena política y cultural argentina en las décadas de 1960 e 1970, así como la creciente violencia de Estado en aquel período. A partir de esas observaciones, propias de un abordaje materialista del discurso, la investigación que realizamos se constituye como exploración innovadora acerca del rock argentino. El trabajo también dio lugar a reflexiones teóricometodológicas alrededor de los agrupamientos del discurso, y de posibles relaciones entre configuraciones enunciativas y regularización.

Palabras clave: rock argentino -regularización discursiva - cultura argentina del siglo $\mathrm{XX}$ - análisis materialista del discurso 


\section{SUMÁRIO}

Introdução - Objetivos e organização da tese

Capítulo I - Fundamentos teóricos e metodológicos 21

1. Sujeitos, interdiscurso, memória discursiva 22

2. Regularização, desregularização e conflito no nosso trabalho 26

3. Pessoa, vozes e cenografia 28

4. Os agrupamentos do discurso e a nossa pesquisa 31

4.1 Problematizando os agrupamentos $\quad 32$

4.2 Agrupamentos, espaço social e interdiscurso 34

5. A dimensão sonora 36

$\begin{array}{ll}\text { Encerramento } & 40\end{array}$

Capítulo II - O denominado "rock argentino" e a nossa pesquisa 41

1. Um questionamento em todas as ordens 42

2. Música, reprodução e cultura de massa 46

3. O "rock argentino" e sua inserção na conflituosidade 48

3.1 Uma primeira delimitação dissidente 49

3.2 Gênero? Movimento? Campo? As aderências do nome "rock". 51

4. O primeiro rock argentino e o confronto ideológico e discursivo 56

5. As indagações e o corpus desta pesquisa

6. Estabelecimento de letras e outros esclarecimentos sobre fontes 64

7. O caderno de Anexos 65

$\begin{array}{ll}\text { Entrando nos percursos } & 66\end{array}$

Capítulo III - Morte sem mortes; estados de amor

(Indiferença) 67

1. Carência e bordas $\quad 71$

2. Coisas a evitar $\quad 73$

3. Faits divers 76 
4. O melodramático e o "progressivo" argentino 79

5. Formas do amor em cena $\quad 84$

6. A pré-história e o corte. Enunciar-se em solidão. 86

$\begin{array}{ll}\text { 7. Sem fatalidade } & 90\end{array}$

\section{Capítulo IV - Observando a regularização}

$\begin{array}{ll}\text { (Pirmeiro percurso) } & 91\end{array}$

1. A configuração da mudança crítica 92

1.1 Nascer, sair. Passando por si. $\quad 92$

1.2 El lugar que yo más quiera 94

$\begin{array}{ll}1.3 \text { Correr, marchar } & 97\end{array}$

$\begin{array}{ll}1.4 \text { Verdade e prática artística } & 99\end{array}$

$\begin{array}{ll}1.5 \text { A cronografia do amanhecer } & 102\end{array}$

1.6 Solo y nada más 105

$\begin{array}{ll}1.7 \text { Al fin mi duende se abrió } & 108\end{array}$

1.8 Recapitulando 114

2. Procurando filiações 115

2.1 Dialogando com outros estudos 116

2.2 As formas diversas do "humanocentrismo" e o papel do 119 indivíduo

2.3 A regularização como embate. Saberes e sujeitos.

\section{Capítulo V - El Hombre de la Tapa}

(Primeiro caso)

1. Um encarte especial

2. Nosso propósito e um contraponto 137

3. Glosas não interrogadas 139

4. Assimetria dos cantares 142

5. Definitude e instantâneas 147

6. Laura, entre el sol yél 150

7. Aunque no eres real, vas a perder tu amor 155 


\section{Capítulo VI - Pessoa, entorno e percepção}

(Segundo percurso) 157

1. Indagando a figuração 159

1.1 A prosopopeia na retórica clássica $\quad 160$

$\begin{array}{ll}1.2 \text { A fala como critério } & 161\end{array}$

1.3 O lugar da percepção 164

1.4 Uma proposta a partir da enunciação 165

$\begin{array}{ll}1.5 \text { Figura e regularidade } & 169\end{array}$

2. Prosopopeias, deslocamentos 172

2.1 Pulando do melodrama 172

2.2 De volta aos muchachos 174

2.3 Vírgenes de sí 177

2.4 Do automático ao refúgio 182

2.5 Si es que el sol te ve 185

Capítulo VII - Tango flutuando e imprecação em cena

(Segundo caso) 187

1. O palco do escárnio 189

2. Os motivos da condena 193

$\begin{array}{ll}3 . & 195\end{array}$

$\begin{array}{ll}\text { 4. Heterogeneidade e estabilização } & 199\end{array}$

\section{Capítulo VIII - A (não) encenação da luta política}

(Não indiferença) 201

1. Delimitando uma ausência 203

2. Alguns limites 204

3. Uma nova alteridade em relação à militância 208

3.1 As formas da revolta e do terrorismo de Estado 210

3.2 A cidade era uma blitz 212

4. Uma elipse significativa 213

5. Efeito de campo e anacronismo. Duas saturações da "lucha". 217

$\begin{array}{ll}\text { 6. Entrando na consternação } & 219\end{array}$ 
Capítulo IX - Canciones del cielo final

(Terceiro percurso) 221

1. O quarto, o muro, bajo otros cielos 223

2. O acaso, o pánico, o riso 231

3. Morirás, Goliat 235

$\begin{array}{ll}\text { 4, Escada para a terraza } & 239\end{array}$

Capítulo X - Escondeme en tu memoria

(Terceiro caso) 247

1. ¿Dale que nos morimos? 248

2. Escarbo hasta abrazarte 250

3. Ausência e refúgios 255

4. O humano entre túmulos 257

5. Un hombre que debe andar 261

$\begin{array}{lr}\text { Considerações finais } & 265\end{array}$

$\begin{array}{ll}\text { Referências } & 270\end{array}$ 


\section{Introdução - Objetivos e organização da tese}

Em um manifesto denominado "Asesinato del rock", divulgado há dez anos, o cantor e compositor argentino Pablo Dacal se proclama como parte de um novo ciclo musical que deve ser construído. O texto retoma, logo no início, a denominação do ciclo que o título anuncia como superado:

El rock ya no nos representa sino en parte, como el tango o la música romántica. Algo de nosotros puede ser dicho en sus términos, pero son géneros que representan la experiencia de generaciones pasadas, no la nuestra. (DACAL, [2006] 2008, p 207)

$\mathrm{Na}$ analogia construída, o termo "rock" é posto na mesma série que um gênero ou grupo de gêneros, o tango, nitidamente atribuído à Argentina no quadro referencial da proclama, e de uma identidade mais difusa, "a música romântica". O "nós" em que o locutor se inclui é determinado como "nossa geração", que precisa diferenciar-se de outras passadas. Se a anunciação da nova música de uma geração argentina precisa darse sob a emancipação de algo que se designa como "rock", há alguma força atribuída àquilo que se enquadra sob esse termo, algo que parece inevitável para considerar as relações de gerações com a produção e a escuta musical naquele país. Não casualmente, o texto foi lido em um recital coletivo, do qual Dacal participou, que comemorava os 40 anos do "primeiro recital", em 1966 ${ }^{1}$. Primeiro recital do quê? De algo que, em 66, ainda não tinha nome nem se anunciava como primeiro, porque essa qualidade só lhe seria atribuída muito depois, na construção de relatos em torno de uma "origem"2.

O espaço amplo e heterogêneo de práticas que, na Argentina, foi recebendo o nome de "rock nacional" começou a ser objeto da nossa atenção, como pesquisadores, aproximadamente em 2005, embora de tempo atrás a memória dessas canções vinha em

\footnotetext{
${ }^{1}$ A série de concertos, na Biblioteca Nacional de Buenos Aires nos dias 6 e 7 de dezembro de 2006, recebeu o nome de Aquí, allá y en todas partes, o mesmo de uma série de recitais realizada no pequeno Teatro de la Fábula em dezembro de 1966, marco pré-histórico do que mais tarde deviria em "rock argentino", e da qual não há registros gravados.

${ }^{2}$ Como esperamos surja da leitura dos capítulos II e III, não cremos que haja havido um "primeiro recital" nem uma origem datada; vemos essas efemérides como algumas das manifestações mediante as quais um campo institucionaliza sua identidade, e que merecem atenção como fatos de discurso.
} 
trabalhos nos quais comparávamos, a partir de critérios diversos, enunciados em português brasileiro e espanhol da Argentina. Assim, quando decidimos abordar "de vez" essa discursividade que voltava insistentemente, planejamos um estágio pós-doutoral na Argentina com um objetivo inicial: levantar o "estado da arte" da pesquisa e da crítica, em diversos campos das humanidades, acerca desse fenômeno. Percorrendo várias universidades, bibliotecas e centros de pesquisa nas principais cidades do país, e mantendo entrevistas com diversos estudiosos, críticos, jornalistas e compositores, levantamos e analisamos em torno de 60 trabalhos acadêmicos incluindo artigos, capítulos, livros, dissertações e teses; um número relativamente baixo considerando o alcance desse campo de produção musical e a abundância de publicações jornalísticobiográficas em torno dele.

Os resultados desse levantamento foram publicados em um artigo (Fanjul, 2008), no qual informávamos um claro predomínio de estudos fincados nas ciências sociais e da comunicação, que tratavam o "rock nacional" principalmente como espaço de construção identitária juvenil. Pouquíssimas vezes havia uma abordagem da materialidade musical, e a materialidade verbal só era aludida a partir dos "temas" que alguns trabalhos levantavam como "característicos". Apenas um estudo, o de Diaz (2005), indagava com alguma sistematicidade no fio discursivo para abordar tópicos reiterados, mas sem tentar estabelecer, por não ser esse seu foco, séries para análise em torno de alguma categoria específica. Conhecemos, também naquela oportunidade, o pesquisador Diego Colomba, que estava realizando uma investigação de doutorado em estudos literários em torno da letrística do rock local, que iria dar lugar futuramente a sua tese (COLOMBA, 2010), um novo trabalho em que a materialidade verbal seria objeto de uma interrogação específica, visando a uma classificação no que ele denominou como "linhas estilísticas".

Nos anos seguintes, fomos produzindo alguns trabalhos pontuais em torno do rock argentino, inseridos nos projetos de pesquisa que desenvolvemos na Universidade. Em alguns desses textos efetuamos comparações com composições musicais brasileiras em relação à representação de alguns objetos de discurso (FANJUL, 2009a e 2009b) e ao agenciamento enunciativo (idem, 2010 e 2013a). Em outros, tratamos exclusivamente de composições argentinas, à vez que íamos identificado traços discursivos que nos apareciam como recorrentes. Estudamos, assim, algumas tendências contraditórias no que diz respeito à representação da atividade criadora (idem, 2013b) e da resistência política 
(idem, 2013c), e características da enunciação biográfica em diversas etapas da história do rock desse país (idem, 2014).

Ao longo desses anos, nos quais mantivemos e intensificamos o contato com alguns pesquisadores que tínhamos conhecido a partir do nosso pós-doutorado ${ }^{3}$, produzimos reflexões e nos deparamos com descobertas que foram ficando à margem das escritas de artigos. Somadas às indagações que realizávamos para cursos ou debates, elas fizeram com que percebêssemos que estava na hora de desenvolver um trabalho de fôlego, exclusivamente sobre o discurso no rock argentino, que abordasse de cheio um conjunto de problemas e um recorte específico. Assim foi que, no segundo semestre de 2013, elaboramos o projeto que deu lugar a esta tese que aqui apresentamos, e que é um material inédito.

O objetivo principal desta tese é produzir uma caracterização e uma reflexão integral acerca de um processo de regularização que atravessa o discurso do rock argentino nas suas primeiras épocas. No Capítulo II, item 5, detalharemos em torno de quais eixos e categorias de análise indagaremos tanto essa regularização quanto o que vemos como um processo de desregularização parcial que a afeta. E no primeiro capítulo, onde apresentamos as principais bases teórico-metodológicas, explicaremos por que essas bases nos levam a ver esse trabalho de caracterização e explicação que é nosso objetivo como a construção de hipóteses abrangentes.

No desenvolvimento da pesquisa que culmina com este texto, os objetivos particulares perseguidos para atingir esse propósito geral tiveram a forma de observação, no corpus que foi delimitado, de regularidades para determinadas configurações enunciativas e para a construção de alguns objetos de discurso em torno dos quais tiveram grande relevância as exclusões, as não presenças. Na forma que ganhou a tese como texto, a indagação dessas configurações e objetos é a articulação central da análise e da explicação. Eles serão apresentados na mesma seção do Capítulo II que acabamos de indicar, embora a descrição da tese que faremos a seguir permita, de fato, uma primeira aproximação.

\footnotetext{
${ }^{3}$ Com Claudio Díaz e Lucio Carnicer mantivemos um intercâmbio fluido durante os anos em que coordenamos um projeto de cooperação internacional com a Universidad de Córdoba, incluso participamos do curso que o primeiro deles ofereceu na USP em 2015. Pablo Vila, da Temple University, integrou nosso trabalho de 2014 a um dos seus livros e supervisou o estágio sandwiche de uma doutoranda nossa.
} 
O Capítulo I apresentará a fundamentação teórico-metodológica, situando nosso trabalho em uma concepção materialista e abordando os problemas do sujeito do discurso em relação com a regularização, das instâncias de pessoa e das vozes no processo enunciativo, das classificações do discurso nas práticas sociais, e do lugar que daremos à dimensão sonora na nossa análise. No Capítulo II, situaremos o denominado "rock argentino" como campo da produção cultural no país, especificaremos o período da sua existência que constituirá nosso objeto de estudo e detalharemos quais serão nosso focos de análise e observação. Nesse capítulo será apresentado um panorama da situação política e das transformações na produção cultural argentina nas décadas de 1960 e de 1970, que terá especial relevância porque, a partir dela, exporemos os perfis do confronto ideológico que iremos relacionando, nos capítulos posteriores, à regularização discursiva no campo do rock argentino. No final do Capítulo II constam as indicações sobre a pasta anexa que contém letras transcritas e um CD das músicas.

No Capítulo III é que tem início propriamente o desenvolvimento da nossa exposição em torno dos objetos estudados. Mas ela não começa pelo núcleo aparente da regularização, mas pelas suas bordas. Tratamos nesse capítulo sobre determinadas possibilidades para a representação da morte e dos vínculos amorosos que não encontramos no rock argentino das primeiras épocas, e que nos interessaram porque tanto o amor quanto a morte são tópicos extremadamente reiterados. A tentativa de dar precisão ao que está ausente, isto é, a morte de algum ser específico representado ou evocado e a narrativização do amor, nos leva a uma reflexão sobre as especificidades e exclusões do melodramático no primeiro rock argentino, que será um primeiro fio que conduzirá para a problemática central na regularização: os deslocamentos, as mudanças e as expectativas de ação para o ser humano.

No Capítulo IV, o mais extenso da tese, realizamos um primeiro percurso pelo nível principal do corpus. Nele apresentamos, depois do recurso ao exterior realizado no capítulo anterior, os traços nodais da regularização que postulamos. Percorrendo uma série de músicas que vemos como especiais saliências, vamos mostrando a repetibilidade de configurações dadas por objetos, perspectivas em relação a eles, determinadas articulações das instâncias de pessoa, do espaço e do tempo. Generalizamos como "mudança crítica" a representação de um deslocamento nos seres, especificado por vezes como novo nascimento, desprendimento, saída, começo e outras figurações. Esse deslocamento envolve, em algum ponto, um movimento de distanciamento e 
reaproximação de si, e se articula com cronografias relativas a momentos do dia, com uma exaltação eufórica do representado como "verdadeiro" -muitas vezes relacionado ao percurso autorreflexivo-, e com determinadas representações da atividade artística. A segunda parte do capítulo volta sobre o confronto político e cultural introduzido no Capítulo II, tentando estabelecer filiações interdiscursivas para a regularização postulada, e hipotetizar posições de sujeito, como saberes que estabilizam os objetos de discurso, que atravessam contraditoriamente o campo analisado.

Em toda a extensão do Capítulo V nos detemos sobre um dos LPs mais lembrados e ouvidos das primeiras épocas do rock argentino, o primeiro que publicou a banda Almendra, primeira em que participou o compositor e cantor Luis Alberto Spinetta. Partimos da análise do encarte do disco, que apresentou características que rompiam com a expectativa para esse tipo de paratexto musical, para, a partr dele, nos direcionarmos às canções. Mediante uma análise centrada nos processos de determinação linguística e discursiva, relacionamos esse disco ao processo de regularização que começamos a indagar no capítulo anterior, e a algumas das exterioridades observadas no terceiro. As análises sobre o disco e suas músicas são realizadas em contraponto com observações sobre um curta filmado na época, e sobre uma música de The Beatles que Spinetta aponta como "inspiração" para uma das canções do LP.

O Capítulo VI focaliza, a partir de um novo percurso pelo mesmo corpus, as vinculações entre os seres postos em cena e seu entorno. Levantamos, para tanto, as reiterações de um tipo de figuração que pode ser vista como uma variante da personificação ou prosopopeia. Depois de descrever o fenômeno, tentamos uma caracterização, para o qual realizamos uma revisão de formulações nas tradições retóricas e estilísticas acerca da personificação, questionando esses conceitos a partir de categorias da enunciação. Abordamos posteriormente ocorrências dessa figuração no corpus, indagando seu funcionamento em relação às perspectivas enunciativas.

Um dos casos de ocorrência desse tipo de figuração é o ponto de partida do Capítulo VII, onde abordamos uma configuração enunciativa que envolve a interpelação, por parte do locutor, a personagens postos em cena como anti-modelo. O capítulo se organiza em torno da análise de uma canção e de aspectos do encarte do disco em que foi gravada, mas se direciona também a outras composições do período em que se registra um tipo de encenação análoga. A temática e o desenvolvimento analítico neste capítulo levam a considerações sobre vínculos discursivos entre o primeiro rock argentino e 
vertentes do tango das décadas de 1920 e 1930, bem como sobre os papéis muito diferentes que essas modalidades tiveram na conflituosidade social, o que significará voltar parcialmente sobre a questão do melodramático.

No Capítulo VIII abordaremos as formas do político nas primeiras épocas do rock argentino. Questionaremos, a partir da concepção que assumimos sobre o discurso, as afirmações corriqueiras sobre o caráter "apolítico" desse campo, tentando dar precisão às formas que assume o político nessas práticas musicais e ao que efetivamente ficou por fora delas. Em certo modo, tratamos aqui, como no Capítulo III, sobre aquilo que não se apresenta no campo estudado ou que se localiza nas suas bordas, mas se trata de uma ausência diferente; visível, debatida, objeto de metadiscurso de e sobre os artistas, embora seja, como tentaremos mostrar, um metadiscurso (passado e presente) tomado pelo efeito de formações imaginárias. No mesmo capítulo voltamos sobre o conflito sócio-político na Argentina para expor dados que mostram, a partir de 1970, um crescimento constante da radicalização e uma ação cada vez mais intensa de formas de terrorismo de Estado. Esse processo é concomitante com a entrada de um novo setor juvenil, muito mais abrangente e diversificado, na participação e mobilização política, e com uma relativa ampliação do alcance do "rock nacional" na juventude urbana, alcance que, como explicaremos, nunca chegou a ser realmente de massa no período que estudamos nesta tese. Essas transformações vão dando lugar a interseções entre esses setores e a acontecimentos discursivos que vemos como uma desregularização parcial do discurso no rock argentino. No final do capítulo denominamos esse processo como “consternação", antecipando alguns dos seus traços.

O Capítulo IX é um percurso por composições nas quais cremos que se manifesta essa “consternação". Explicamos, por meio das análises, como esse processo aponta para alterações em traços enunciativos, cenográficos e em objetos de discurso que se manifestam na regularização que postulamos capítulos atrás. Tentamos caracterizar, também, outras posições de sujeito que começam a delimitar-se e que se relacionam a saberes do que denominaremos "retirada" e que caracteriza essa tendência. O capítulo é encerrado com a discussão de um poema do escritor argentino Fabián Casas, que alude fortemente aos primeiros anos 70 , focalizando retrospectivamente uma diferença crucial entre duas faixas etárias dos jovens e adolescentes daquele tempo. A partir dessa leitura, introduzimos o que explicaremos como uma certeza da privação e da falta. 
O último capítulo aborda parte da produção inicial do compositor, pianista e cantor Charly García, principalmente a que realizou com a dupla Sui Generis, e é um desenvolvimento das problemáticas introduzidas no anterior a partir da análise do poema de Casas. Retomamos também, nesse capítulo X, as figurações da morte e do vínculo amoroso, desta vez sob tônicas que oscilam entre a uma melancolia cálida de refúgio e a lobreguidão. O capítulo termina com a abordagem de uma gravação na qual identificamos um modo de heterogeneidade enunciativa que se direciona para uma regularização diferente, e que somente terá vigor em épocas posteriores do desenvolvimento do rock argentino. A análise, em torno dessa mesma música, das reformulações de fragmentos censurados, dá ocasião a um encerramento que sintetiza alguns problemas tratados.

Nas considerações finais tentamos uma avaliação do percurso realizado em relação aos objetivos propostos, formulando possibilidades de cotejar os processos de regularização observados em outros campos e gêneros na época. Tentamos também ponderar contribuições possíveis para os estudos da enunciação e do discurso, bem como para a produção de conhecimento em torno do rock argentino e da cultura desse país.

O leitor pode ter percebido já no Sumário que, a partir do terceiro, os nomes de todos os capítulos incluem um subtítulo entre parênteses. Essas indicações sinalizam nosso desejo de uma cartografia de leitura. A abordagem de duas ausências, uma indiferente e a outra não (porque cristalizada como uma evidência que não requereria interrogações) dá passagem a duas instâncias do processo de regularização, que tentamos metaforizar mediante os termos que formam o título desta tese, "mudança" e “consternação". Dois percursos estão dedicados ao primeiro e um ao segundo. E para cada percurso abordamos mais demoradamente um caso específico, como ponto de partida para ramificações que estabelecem relações, também, com aspectos tratados em outras seções. Preferimos, de qualquer modo, não dividir a tese em duas partes. Primeiro porque, como explicaremos, o que identificamos como "desregularização parcial” é concomitante com a regularização já postulada e não é concebível sem ela. E também porque preferimos uma organização paratextual que reflita com fidelidade as continuidades e retomadas entre capítulos que não são adjacentes.

Quase por último, queremos antecipar que, por momentos, assumimos, na escrita, um tom ensaístico. Os lugares onde damos lugar a esse tom não são os da discussão teórico-metodológica, nem os núcleos de síntese, recapitulação e retomada, articuladores 
de um trabalho que se propõe como uma tese com objetivos e procedimentos delimitados. Pensamos que a interação entre o objeto, o instrumental analítico e nosso lugar de pesquisador promove que os percursos de análise assumam momentos em que, como caracteriza Adorno ([1958] 2003, p 35-36) em torno do ensaio, “a totalidade resplandeça em um traço parcial, escolhido ou encontrado, sem que a presença dessa totalidade tenha de ser afirmada" (muito embora, infiéis ao ensaio, nosso trabalho persiga, finalmente generalizações). Nosso objeto se constrói a partir de uma matéria verbal, vocal e musical que tem o poético como traço irrenunciável. E há instâncias da escrita analítica, parafraseando novamente Adorno, em que se "compõe experimentando", virando e revirando o objeto, e nossa palavra entra em contato / conflito com essa poeticidade, sem pretender sair ilesa, apenas voltar aos rumos explicativos no momento necessário.

Finalmente, evitamos o mais possível, para esta escrita em português de um trabalho a ser defendido no Brasil, que nossa familiaridade com o campo do rock argentino e suas tradições discursivas mobilizasse implícitos ou fraseologia que podem ser úteis pela sua força explicativa, mas não são igualmente legíveis para quem não tem essa familiaridade. Esperamos ter conseguido essa extraposição, e desde já nos desculpamos se algo disso passou desapercebido. 


\section{Capítulo I}

\section{Fundamentos teóricos e metodológicos}

Neste capítulo apresentaremos os principais pressupostos teóricos e metodológicos que embasam a delimitação dos objetivos desta tese e o trabalho analítico desenvolvido, deixando ainda alguns aspectos da metodologia para o capítulo seguinte. Começaremos por explicar, no item 1, o lugar que adotamos dentro dos estudos discursivos, a partir do qual tentaremos estabelecer o que entenderemos como "processos de regularização" e de "desregularização" acontecendo no discurso que atravessa nosso objeto de estudo -como já anunciado na Introdução, as primeiras etapas do que viria a conhecer-se como "rock argentino". Esse primeiro movimento implicará tratar incialmente sobre os conceitos de "interdiscurso" e de "sujeito", para, a partir deles, chegar à regularização no item 2. Seguidamente, em 3, abordaremos o embasamento de um conjunto de categorias de análise, para o qual versaremos sobre a problemática da pessoa e da voz na enunciação e no discurso, e sobre categorias descritivas que dizem respeito a outros aspectos da enunciação estreitamente relacionados à pessoa, tais como a perspectiva, o olhar e a representação do espaço-tempo. Posteriormente, e considerando que nosso corpus se constitui basicamente a partir de um "gênero" da cultura de massa, trataremos, no item 4, sobre a instabilidade contraditória que o referencial teórico que adotamos considera para a delimitação de agrupamentos do discurso como "gênero", “tipo" e outros. Por razões de ordem expositiva, a especificidade, para o rock argentino, sobre essa inserção sócio-histórica em tanto gênero, não será tratada nesse momento, mas no capítulo seguinte e, de modo geral, retomada em muitos outros momentos da tese. Por motivos análogos, a explicação sobre como se conformam os corpora de pesquisa e sobre os aspectos que indagamos neles será feita também no capítulo próximo. Por último, mas não menos importante, dado que nosso objeto de estudo inclui, em boa medida, canções, abordaremos no item 5 o modo como abordamos a materialidade verbal em relação à dimensão sonora necessariamente envolvida nessas produções, o que nos levará a retomar a questão da "voz" e a tratar sobre o corpo "do canto e da escuta". 


\section{Sujeito, interdiscurso, memória discursiva}

Em diversos tipos de estudos sobre a linguagem encontramos denominações como "sujeito falante" para referir-se ao indivíduo empírico que fala, escreve -ou, por que não, que canta- em situações específicas. Também aparece por vezes a denominação "sujeito enunciador" para a voz que assume a palavra ou que se representa no texto como fonte do dito, ou para outros tipos de manifestações da pessoa, às quais nos referiremos na seção 3 deste capítulo. Nossos estudos e nossos caminhos de pesquisa e reflexão têm feito com que indaguemos respeitosamente diversas abordagens do discurso, tentando captar suas possíveis contribuições embora não concordemos com aspectos mais ou menos centrais da sua proposta. Neste mesmo capítulo poderá perceber-se que o modo como confrontamos algumas conceitualizações evidencia esse interesse em compreender e situar, que vemos como parte da própria pesquisa. Isso não significa que não adotemos, diante de questões cruciais como a da subjetividade, escolhas teóricas relacionadas à concepção materialista que assumimos, vendo a linguagem como arena de confronto de forças na formação social. Por isso, cremos que o problema do sujeito na linguagem não é contido pelas figuras da enunciação, nem muito menos é localizável nos indivíduos empíricos. Nossa opção, dentro dos estudos discursivos, é pelas concepções teóricas que que descentram o falante como fonte do dizer e dão primazia às relações interdiscursivas, considerando que o sentido e o sujeito do discurso se constroem em e por essas relações.

Essa opção foi constituindo-se a partir do nosso estudo da corrente materialista de análise do discurso que teve início no final dos anos sessenta a partir de trabalhos de Jean Dubois e, fundamentalmente, Michel Pêcheux (MALDIDIER, 1994). Boa parte da conceitualização desta tese se apoia em estudiosos dessa corrente, além de Pêcheux, Paul Henry, Jean-Jacques Courtine e Jacqueline Authier-Revouz. Como explica quem fora sua principal introdutora no Brasil, Eni Orlandi (2011, p 14), essa corrente recebeu algumas vezes o nome de "Escola Francesa de Análise do Discurso". Diversos estudiosos que, no Brasil, se localizam na continuidade desses estudos, e dos quais temos aprendido imensamente na nossa carreira como pesquisadores, serão referência nesta tese no que diz respeito à conceitualização do agenciamento enunciativo e de algumas relações parafrásticas.

A leitura do nosso trabalho mostrará que alguns focos de interesse nos levaram a adotar, principalmente para a observação da mídia e da reprodução de bens culturais, 
algumas categorizações que, segundo como se considere o diálogo dessa corrente com a teoria social, poderiam ser vistas como relativamente distantes. $\mathrm{Na}$ abordagem analítica, será visível, também, que incorporamos ao instrumental algumas noções propostas por Dominique Maingueneau, estudioso do discurso relativamente afastado dessa linha, como a de "cenografia enunciativa", embora discordemos de outros aspectos centrais da sua teorização, que aqui não adotaremos.

Quanto à construção teórico-metodológica que realizou a escola de Pêcheux e seus colaboradores, cremos que sua concepção do interdiscurso, sobretudo aquela que Pêcheux atinge nos seus últimos trabalhos em relação à memória, e o modo como essa linha de pensamento foi integrando e reformulando a concepção foucaultiana de sujeito têm uma grande vigência para além das categorias descritivas que, em diversas etapas e ocasiões, têm sido empregadas, e tentaremos situar nosso trabalho tendo essa concepção como referente.

O domínio das relações entre enunciados que se denomina "interdiscurso" tem uma ordem determinada pelas relações de forças em uma formação social. Em uma etapa da reflexão da corrente francesa, a procura dessa ordem estava muito relacionada a uma visão da ideologia como "formações" determinadas pelos aparelhos políticos, muito influenciada pela obra de Althusser (1970), o que levava a uma percepção relativamente fechada do interdiscurso. Assim, em Pêcheux e Fuchs (1975, p 21), "interdiscurso" é definido como exterior "específico" de um dado "processo discursivo", que por sua vez é um conjunto de enunciados relacionado a "condições de produção estáveis e homogêneas" (ibidem, p 24) relacionadas diretamente a posicionamentos na luta de classe e nos aparelhos institucionais. É nessa época quando Pêcheux e seu grupo adotam a noção de "formação discursiva" formulada primeiramente por Foucault ([1969] 1972) como categoria para abordar regularidades, e a adaptam criticamente a essa visão, considerando que as formações ideológicas contam com diversas formações discursivas disponíveis como materialidade verbal. $\mathrm{O}$ interdiscurso seria, então, o de uma formação discursiva determinada. O falante, mediante um processo de "assujeitamento", é conduzido a uma identificação não consciente com o "sujeito universal" de uma formação discursiva, aquilo que "já fala" na construção de objetos de discurso nessa formação.

O trabalho de Courtine (1981) sobre o discurso comunista direcionado aos cristãos será decisivo para uma abertura dessa visão do interdiscurso a um escopo mais amplo de relações de contradição, já que mostra a formação discursiva como não homogênea e 
determinada pelo seu exterior. Em relação ao problema do sujeito, Courtine propõe o "sujeito universal" próprio a uma formação discursiva como um "sujeito do saber" dessa formação, característica que o vincula à construção dos objetos de discurso como evidências dadas, já que nesse sujeito do saber se fixa a estabilidade referencial desses objetos (ibidem, p 42). Naquela etapa da escola francesa, esse estudioso explora os diferentes matizes da noção de sujeito que Foucault ([1969] 1972, p 121-126) desenvolveu na Arquelogia do saber: o sujeito como uma função vazia e disponível para ser ocupada, a posição em que o indivíduo deve situar-se para dizer, independente da sua intenção. O sujeito é o que caracteriza a "função enunciativa", o que faz com que uma formulação possa ser vista como enunciado e, como veremos em 4.1, possa ser-lhe atribuído um domínio. Como o sujeito não tem continuidade na dimensão linear do texto, diversas posições podem aparecer e modificar-se nele. Courtine (1981, p 42-48) adota a proposta da descontinuidade textual do sujeito entendido como função, sem deixar de apontar o que julga, na construção foucaultiana, como desatenção para as relações entre discurso e ideologia, e entre discurso e língua.

Michel Pêcheux mostra, nas suas últimas produções, alguns deslocamentos em relação ao modo como tinha pensado primeiramente as relações interdiscursivas. Desenvolve uma revisão crítica sobre o modo como foram adotadas as teses althusserianas e a visão fechada da formação discursiva como "máquina discursiva de assujeitamento dotada de uma estrutura semiótica interna e por isso mesmo destinada à repetição" (PÊCHEUX, [1983] 2002, p 56). Nesse texto, como em Pêcheux ([1982] 2011 e [1983] 2007), o interdiscurso é caracterizado como espaço de memória discursiva, sustentado no funcionamento de pré-construídos e de relações parafrásticas entre enunciados, trazendo inclusive, a noção bakhtiniana de "dialogismo" (idem, [1982] 2011, p 142). O processo pelo qual a memória discursiva vai configurando-se e modificando-se é de regularização, mas também, como veremos mais amplamente no item 2 deste capítulo, passível de desregularização pelo acontecimento.

Enfim, esse nível de subjetividade que se constitui pelas relações entre enunciados -sujeito dos saberes já dados, regularização da memória em um domínio- precisamente por ser determinado por essas relações, só é hipotetizável mediante observações que excedem não apenas um ou outro enunciado mas, do nosso ponto de vista, também os limites de um determinado gênero. Ele requer indagar em que representações e visões de mundo, em que lugares do conflito ideológico de uma época em uma formação sócio- 
histórica, se estabilizam os objetos de discurso e os pré-construidos. Por isso, para nossa construção explicativa nesta tese, tomamos algumas decisões teórico-metodológicas.

Ao longo das análises, formularemos diversas hipóteses de filiações para posições de sujeito que atravessam contraditoriamente o discurso no primeiro rock argentino. Para tanto, procuraremos caracterizações e denominações que possam designar, figurativamente, tendências em pugna no debate cultural e político ("humanocêntrico", "cético", "revolucionário", "tecnocrático"), e/ou modulações de algumas delas ("retirada"). Não postulamos, por exemplo, um "sujeito do rock", nem da Argentina nem do mundo. Podemos falar, sim, de um "lugar de dizer" roqueiro, mas isso já se localiza no plano das instâncias de pessoa e das vozes, como veremos no item 3 a partir de Guimarães (2005), não do sujeito do discurso ${ }^{4}$. Um "locutor-roqueiro", como outras especificidades que marcam lugares sociais de enunciar pode ser um dos modos de dizerse jovem na Argentina dos 60-70, mas não é um lugar de estabilização de saberes e préconstruidos, como também não o seria, do nosso ponto de vista, um aparelho institucional. Daí nossas opões denominativas para o funcionamento discursivo que tentamos apreender.

Por último, não deve estranhar que, como acabamos de propor no parágrafo anterior, nossos objetivos para a reflexão sobre o interdiscurso e o sujeito sejam precisamente chegar a produzir hipóteses, que vejamos a hipótese como alvo investigativo e explicativo de fôlego. Cremos que isso não restará, como esperamos que seja visível, conclusividade ao nosso trabalho. Nosso empenho afirmativo estará na postulação e descrição das regularidades, na sua exposição rigorosa e nítida -e, portanto, questionável, criticável- na materialidade, na exaustividade e na clareza quanto à constituição do corpus. Que nosso investimento, ao postular modos como essa materialidade integra o ideológico, se apresente como meta e, no mesmo gesto, como produção de uma hipótese tem a ver, por um lado, com que todo processo de identificação parafrástica (FUCHS, 1982), ainda mais no nível de abstração que supõe postular tendências em um campo tão vasto, é um trabalho criativo próximo do ensaio, cujo requisito pode ser a coerência e o rigor descritivo e explicativo, não a univocidade. Por outro, se relaciona à “questão de responsabilidade” com que Pêcheux ([1983] 2002, p 57) encerra sua reflexão sobre a posição de trabalho de análise:

\footnotetext{
${ }^{4}$ Guimarães, na obra referida, diferencia, precisamente, lugares sócias de dizer e posições de sujeito.
} 
Ela supõe somente que, a través das descrições regulares das montagens discursivas, se possa detectar os momentos de interpretações enquanto atos que surgem como tomadas de posição, reconhecidas como tais, isto é, como efeitos de identificação assumidos e não negados.

Aprofundaremos, a seguir, a problemática da regularidade, relacionando-a também ao caráter conflitante das práticas discursivas.

\section{Regularização, desregularização e conflito no nosso trabalho}

Nesta tese postulamos uma primeira regularização que atravessa o discurso no rock argentino, e posteriormente uma desregularização parcial. Nas seções em que essa percepção será amplamente descrita, a partir do Capítulo IV, será visível que a repetibilidade de determinados objetos, de configurações das instâncias de pessoa, de tópicos, bem como da sua articulação sob determinadas perspectivas, dá uma impressão, precisamente pela sua recorrência, de auto-regulação -não obstante as determinações ideológicas, sócio-históricas que tentaremos fundamentar-. Relacionamos essa impressão ao "efeito de série" que Pêcheux denomina em um texto em que comenta formulações de Pierre Achard sobre relações entre a memória e o pré-construído:

Haveria, sob a repetição, a formação de um efeito de série pelo qual uma "regularização" (termo introduzido por P. Achard) se iniciaria, e seria nessa própria regularização que residiriam os implícitos, sob a forma de remissões, de retomadas e de efeitos de paráfrase (que podem a meu ver conduzir à questão da construção dos estereótipos). (PÊCHEUX, [1983] 2007, p 52)

Cremos que as condições de aparecimento do campo, incialmente muito restrito, do que depois deveio em "rock argentino" favoreceram esse efeito de série, que foi diluindo-se $\mathrm{s}^{5}$ na medida em que o campo se expandiu e diversificou, ampliando os "efeitos de paráfrase" a novas filiações interdiscursivas. No capítulo seguinte explicaremos

\footnotetext{
${ }^{5} \mathrm{Ou}$ ganhando formas de repetição ritualizada, deslocada das relações interdiscursivas em que participou de determinados sentidos, como nos sugere a observação de períodos do rock argentino posteriores ao que esta tese abrange e que não trataremos aqui.
} 
amplamente essas condições, agora nos deteremos nas características do que, a partir da mesma teorização, entenderemos como "desregularização".

Para Pêcheux, nesse trabalho e no outro do mesmo ano que já referimos ([1983] 2002), a regularização pode ser perturbada por um novo acontecimento discursivo. Haveria "Um jogo de força na memória sob o choque do acontecimento" (idem,[1983] 2007, p 53). Uma força que visa manter a regularização pré-existente e a força de uma desregulação que a perturba. No nosso trabalho, a partir do Capítulo VIII, analisaremos o que consideramos uma desregularização parcial, já que há uma "agitação nas filiações sócio-históricas de identificação" (idem, [1983] 2002, p 56) e não um "ruir" dessas filiações, imagem que o estudioso emprega em outro momento.

A percepção da regularização como resultado de um jogo de forças em movimento constante nos leva para o caráter conflitivo do enunciar, e para a própria noção de regularidade. Podemos localizar, antes dessa corrente de análise do discurso, mas na tradição materialista em que situamos nosso trabalho, teorizações que mostram a atividade de linguagem como constitutivamente conflituosa. Em Voloshinov ([1929] 2009, p. 47) o que constitui o signo como "ideológico" é a refração nele das diferentes orientações do ser social na luta de classe. E o modo como Bakhtin ([1953] 1997) concebe o dialogismo tem a característica de um conflito: os enunciados obtêm sua "conclusividade" e orientação na sua potencialidade de refutação e contestação em relação a outros enucniados. De outro modo, também em Foucault ([1970] 2008) o fato de enunciar é abordado como conflitividade, no caso, não tanto como confronto de enunciados mas como intervenção sobre o real. Ao alertar sobre não ver o discurso como face decifrável do mundo, o filósofo francês caracteriza o discurso como "una violencia que se ejerce sobre las cosas, en todo caso como una prática que les imponemos" (ibidem, p 53). Essa violência, que seleciona e recorta modalidades de enunciação, temas e objetos, promove a regularidade, conceito amplamente tratado ao longo da Arqueologia do saber como jogo de regras de formação dos enunciados em um campo associado, regras que "los atraviesan y les constituyen un espacio de coexistencia" (FOUCAULT, [1969] 2002, p. 191). Ao serem deslocados para uma abordagem do discurso como materialidade lingüística, esses conceitos foucaultianos receberam especificações. Assim, por exemplo, em Pêcheux ([1983] 2007), a regulação é principio de uma memória discursiva 
apreensível a partir de implícitos (ou pré-construídos, nesse texto Pêcheux alterna entre as duas denominações ${ }^{6}$ ), paráfrases e diversas formas de retomada e remissão.

Assim, em diversos momentos da abordagem do rock argentino que desenvolveremos neste trabalho, tanto a passagem para o que postulamos como sua primeira regularização, quanto a passagem entre ela e sua desregularização parcial serão descritas a partir de pontos de inflexão, nos quais vemos acontecimentos discursivos que apontam para rupturas, conflito que localizamos, em alguns casos, dentro de uma mesma música, no próprio canto. Trataremos a regularização e a desregularização como condensações de acontecimentos discursivos. Preferimos não empregar a categoria de "formação discursiva" porque, pelo que vemos nos estudos que a utilizam, não cremos que sua abrangência possa limitar-se a um único gênero e ao seu campo de coexistência imediato, como os que abordaremos nesta tese. Em todo caso, as regularidades observadas podem embasar um trabalho posterior em que sejam postas em relação com enunciados de outros gêneros e campos na mesma época, como mostraremos nas conclusões.

Também como consequência de que percebemos a regularização como um processo conflitante, de determinações e exclusões que escapam aos sujeitos individuais, é que iniciaremos nossa caracterização desse processo com uma primeira passagem pelo que ele deixa fora. Como antecipamos na Introdução, no Capítulo IV e, em menor medida, no VIII, trataremos sobre bordas e limites que apontam para modos de exterioridade em relação ao que se vai consolidando no campo do que será o rock argentino.

\section{Pessoa, vozes e cenografia}

Em alguns projetos de pesquisa que temos submetido à avaliação de fomento e em um livro de recentíssima publicação (FANJUL, 2017), incluímos sob a denominação de "instâncias de pessoa" um conjunto de fenômenos que abrange os participantes da enunciação reconhecíveis a través de marcas específicas, as vozes trazidas para o discurso

\footnotetext{
${ }^{6}$ Não obstante, o termo "pré-construido" foi cunhado por essa corrente de análise do discurso para diferenciar um modo de compreender o "não dito" inferível de uma sequência discursiva. Como explica Pêcheux ([1982] 2011, p 145-146), ver esse não dito como "já dito" no interdiscurso que constitui a sequência na sua ordem de regularidade ou no seu dompinio de memória, e não como algo inferível a partir de operações lógico-linguísticas, como era, por exemplo, na teorização de Ducrot a que nos referiremos no item 3 ..
} 
mediante os diferentes procedimentos de "heterogeneidade mostrada" (AUTHIERREVUZ [1982] 2011), as entidades pessoais representadas no enunciado como "personagens", e também as perspectivas e saberes atribuídos a cada uma dessas figuras. Explicaremos aqui algumas opções para a categorização descritiva dessas instâncias, bem como a relevância que encontramos para sua abordagem no tipo de análise que realizaremos.

Na sua formulação da "teoria polifônica da enunciação" Ducrot (1980, [1984] 2001) diferenciava as instâncias de "locutor" e "enunciador". O primeiro corresponde à voz que aparece como responsável pelo enunciado, e sua categorização como "ser discursivo" apontava a resolver a não coincidência entre o falante empírico e a voz em diversas situações de mediação, em que a identificação de uma "fonte" se faz mais complexa do que na comunicação cara a cara. O "enunciador", diferentemente, era uma categoria que tratava de outra não coincidência, mais estritamente polifônica: a do locutor com seu próprio dizer. Processos como a ironia, a negação polêmica, a interrogação autoformulada, ou as construções adversativas e concessivas, podem trazer para a fala do locutor uma perspectiva que não lhe é própria. Ducrot ([1984] 2001, p 268) se vale da noção de "sujeito de consciência" na teoria literária para caracterizar esses "enunciadores" que trazem outra perspectiva para o dito.

No Brasil, Guimarães (2005, p 11-31) formula, algumas décadas depois, uma proposta que dialoga polemicamente com o modelo de Ducrot. Propõe a categoria de "locutor-x", na qual a variável representa "lugares sociais de dizer", relacionados a papéis distinguíveis no funcionamento social, a partir dos quais se fala: "locutor-gerente", "locutor-professor", "locutor-artista", etc. Diferentemente, denomina como “enunciadores" diversas modalidades de fala nas quais é apagada a implantação históricosocial do locutor. Em diversos capítulos desta tese, sobretudo no V e VI, identificaremos alguns fenômenos encontrados na análise com essa taxonomia, que oportunamente apresentaremos. A reformulação crítica que Guimarães desenvolveu sobre as categorias empregadas por Ducrot deveu-se ao interesse em considerar a dimensão sociohistórica do dizer. Com efeito, o modelo de Ducrot, centrado na explicação de aspectos do funcionamento linguístico vistos como "instruções sobre o sentido", explicava as diferentes instâncias enunciativas em uma semântica internas ao enunciado, sem dar a possibilidade de considerar, para elas, uma implantação em papéis socialmente prédeterminados. 
Será importante também, nas nossas análises, outra revisão crítica das descrições da enunciação, a que realiza Zoppi Fontana (2004), que atinge de modo geral as propostas "bidimensionais" -falante e ouvinte, “eu" e "tu"- que, desde Benveniste ([1958] 2002) predominam para o estudo desse processo. A autora indaga um lugar para a terceira pessoa na análise enunciativa, reexaminando também, para tanto, o que nos trabalhos de Ducrot e outros é determinado como "perspectiva", deslocando-o para a instância do olhar:

A noção de perspectiva, de focalização, permite a abertura da teoria da enunciação à tridimensão, não só porque incorpora o lugar do ele ao jogo enunciativo, mas porque ao definir sua especificidade, desloca-se do centramento no conceito de voz para a dimensão dispersa do olhar. (ZOPPI FONTANA, 2004, p 61)

Dado que, na linguagem verbal, o "olhar" corresponde ao "complexo processo de categorização/conceptualização fundante do conhecimento" (ibidem, p 61), a perspectiva distribui também a atribuição, a cada entidade pessoal, de "saberes" em torno do que é representado, abrindo uma ponte para a dimensão representacional e ideológica.

Consideramos analiticamente todas essas instancias de pessoa, incluindo os "personagens" dos quais se fala, porque, mesmo como terceiros sem voz especificamente atribuída, sua perspectiva se integra ao jogo enunciativo. E cremos que, ainda nos limites desse dispositivo de enunciação, a observação da dimensão temporal e espacial se enriquece com a categoria de "cenografia enunciativa" como proposta por Maingueneau (2001 e 2008): a encenação de interlocução, tempo e espaço da qual a enunciação, figurativamente, anuncia provir. Como em outros trabalhos que já publicamos, empregaremos aqui as denominações de "topografia" e de "cronografia" para modos mais ou menos recorrentes de articulação espacial e/ou temporal na figuração em que a voz se situa. Assim, denominações descritivas que iremos introduzindo nos próximos capítulos, como "cronografia do amanhecer" ou "topografia do quarto", não pretendem referir-se a imagens que seriam deslocáveis para a descrição de qualquer domínio discursivo. Elas, como se verá, se articulam com objetos específicos e com determinados deslocamentos e percursos dos seres representados, no espaço da discursividade que abordamos.

Precisamente as duas últimas denominações genéricas que acabamos de empregar acerca do nosso objeto de estudo (“domínio”, “espaço”) trazem à tona outra problemática 
teórico-metodológica relevante para nossa pesquisa, como para outras que pretendam abordar o discurso nas condições contemporâneas de circulação e reprodução: a dos gêneros, tipos e outras classificações.

\section{Os agrupamentos do discurso e a nossa pesquisa}

O subtítulo desta tese, que prefigura seus objetos, é "um estudo sobre o discurso no primeiro rock argentino". Por que essa conexão dada pela preposição "em", por que titulamos "no" e não, por exemplo, "do"? A vertente de música urbana que iria recebendo o nome de "rock argentino", especificamente suas primeiras etapas, é, como explicamos na Introdução, nosso principal objeto de estudo. E o abordamos a partir do discurso, como dimensão em que a materialidade linguageira é afetada pelo real sócio-histórico. Porém, não cremos que possa haver discurso "de" um gênero ou campo em particular. Mesmo que tenhamos como objeto de investigação um agrupamento desse tipo, que é do nosso interesse para contribuir, nos estudos das humanidades, para a reflexão sobre a produção cultural de um país em determinada época, cumpre partir do reconhecimento, que deriva do que explicamos em 2 em torno do interdiscurso, de que a ordem do discurso não se configura por esse tipo de agrupamentos, mas os atravessa. Fazemos aqui uma analogia com o que Orlandi (1996) distingue como “ordem” e "organização" na língua, mas, no nosso caso, tratando dos modos como as práticas sociais organizam conjuntos textuais estabilizados sob denominações, especificamente no terreno da produção de bens culturais. Esses conjuntos são um ponto de partida, e foram, no nosso estudo, como veremos no capítulo seguinte, parte fundamental dos critérios de constituição de corpus, mas nossa meta é construir hipóteses sobre como determinadas regularidades discursivas e posições de sujeito os atravessam contraditoriamente, mostrando traços do conflito ideológico e das relações de força em que sua própria delimitação se desenvolve. Trataremos, então, neste item, sobre a relação contraditória entre esses agrupamentos e a regularidade. 


\subsection{Problematizando os agrupamentos}

Embora não situada na perspectiva de uma análise do discurso que atendesse ao funcionamento linguístico, a reflexão de Foucault ([1969] 1972), proposta por ele mesmo como interrogação acerca de como construir uma história das ideias e dos saberes, teve uma forte projeção sobre o desenvolvimento posterior dos estudos discursivos nas ciências da linguagem, mesmo para aqueles que escolheram objetos de análise em domínios muito diferentes, como a política ou a mídia. Já tratamos no item 2 sobre aspectos da sua recepção por uma corrente específica da análise do discurso, mas aqui vamos nos deter em uma problemática particularmente desafiante: a das unidades possíveis para a análise, os agrupamentos textuais que podem constituir um corpus de trabalho para o pesquisador.

A primeira parte da obra referida (A Arqueologia do Saber) começa precisamente enunciando a necessidade de questionar totalidades dadas como "obra" ou "livro", mas também alguns conjuntos previamente estabelecidos pelas tradições críticas, dentre eles alguns de especial interesse para quem trabalha nos estudos da linguagem:

Hay que inquietarse también ante esos cortes o agrupamientos a los cuales nos hemos acostumbrado. ¿Se puede admitir, tal cual, la distinción de los grandes tipos de discurso, o la de las formas o géneros que oponen unas a otras, la ciencia, la literatura, la filosofía, la religión, la historia, la ficción etc., y que hacen de ellas especies de grandes individualidades históricas? (FOUCAULT, [1969] 1972, p 35)

O questionamento está direcionado tanto ao trabalho com discursos da contemporaneidade quanto à aplicação dessas classificações a discursividades do passado. Não é uma preocupação de Foucault, como surge do excerto e da leitura integral da obra, diferenciar entre "tipos", "gêneros", “domínios" ou outras classificações do modo como se tenta nos estudos discursivos ou textuais. Mas essas categorias não deixam de ser atingidas pela pertinência dessa interrogação.

Sabido é que, ao longo da Arqueologia..., Foucault vai formulando a noção de "formação discursiva" como tentativa de abranger regularidades entre enunciados. Sua reflexão sobre o próprio enunciado como "función que cuza un dominio de estructuras y 
de unidades posibles" (ibidem, p 145) formula como condição, para essa função, a relação com um sujeito concebido como lugar a ser ocupado e a existência de um "domínio associado". Essa noção é reformulada ao longo da explicação como "campo adjacente", "espaço colateral”, "campo associado" e "campo enunciativo", e evidencia a necessidade de novos agrupamentos e conjuntos, constituídos por relações que, do ponto de vista dos estudos discursivos, poderíamos resumir como "dialógicas" e/ou "parafrásticas", embora Foucault não tenha empregado esses termos naquela obra, e que certamente são diferentes das relações que podem fundamentar agrupamentos como "tipos discursivos" ou "gêneros do discurso".

Vale a pena, no entanto voltar ao ponto em que o autor discorre sobre a necessidade de questionar os "grandes tipos" e "gêneros", para notar que o questionamento por ele proposto chama a atenção para um aspecto da existência dessas classificações que é de grande interesse para o que aqui tentaremos desenvolver:

De todos modos, esos cortes -ya se trate de los que admitimos, o de los que son contemporáneos de los discursos estudiados-; son siempre ellos mismos categorías reflexivas, principios de clasificación, reglas normativas, tipos institucionalizados: son a su vez hechos de discursos que merecen ser analizados al lado de los otros, con los cuales tienen, indudablemente, relaciones complejas, pero que no son caracteres intrínsecos, autóctonos y universalmente reconocibles. (FOUCAULT, [1969], 1972, p 36).

Precisamente, esses recortes são "fatos de discurso", ou, diríamos nós, de um metadiscurso que se produz em práticas verbais que classificam. Práticas, segundo o caso, mais ou menos insititucionalizadas e de maior, menor ou nula proximidade com as disciplinas da linguagem. O fato de que conjuntos de enunciados se agrupem sob o nome de um gênero é resultado de uma sedimentação de processos de denominação e classificação, que pode passar pela mídia, pela escola, por formas menos institucionalizadas da interlocução, pelo campo científico ou juntamente por vários desses lugares, e cremos que as "relações complexas" que esse agrupamento tem, tanto com os textos que inclui como com os discursos que o delimitam merecem ser estudadas, o que implica reconhecer e tentar situar esse agrupamento.

Por uma parte, já a teorização bakhtiniana abriu a possibilidade de hipotetizar relações dialógicas mediadas pelo gênero, que, pela sua inserção em determinadas práticas, favoreceria uma "expressividade típica" do gênero para a palavra (BAKHTIN, 
[1953] 1997, p 311-312). Inversamente, delimitar a identidade de um gênero levando em conta seu papel nas práticas sociais traz consigo a dimensão dialógica da linguagem, o confronto de vozes e perspectivas que se manifesta nos textos agrupados nessa tipologia.

\subsection{Agrupamentos, espaço social e interdiscurso}

Beacco (2004) desenvolve uma reflexão em relação à delimitação e identidade dos gêneros na contemporaneidade. Como se verá, não concordamos em alguns aspectos, devido ao que nos parece uma divergência mais geral em relação ao funcionamento social e político, mas nos parece interessante trazê-la à tona pela produtiva e original diferenciação que estabelece entre três maneiras de considerar essa categoria, permitindo prever que os três modos não levem, necessariamente, a recortes coincidentes. $\mathrm{O}$ gênero, segundo o autor, poderia ser abordado de três pontos de vista. $\mathrm{O}$ primeiro, do que denomina como "linguística popular", tem a ver com a representação do senso comum: estudar, por exemplo, os processos que levam a que determinados grupos identifiquem e denominem um texto como "coluna de opinião" mesmo que ele não apareça sob esse nome. O segundo, com o estabelecimento de um determinado gênero como categoria mais ou menos "prototípica" por linguistas e analistas do discurso, com base em regularidades e variações entre séries de textos. O terceiro, que é o que nos interessa mais neste trabalho, se relaciona ao que o autor denomina "espacialidade social" do gênero (ibidem, p 116): sua implantação em determinados lugares sociais.

O autor põe em jogo, para a abordagem dessa espacialidade social, uma noção de "comunidade discursiva" de cunho etnolinguístico, que abrangeria os produtores e

consumidores de determinados bens culturais. É a respeito dessa caracterização, bem como da relação proposta entre essas "comunidades" e a mídia que, como antecipamos, não concordamos com Beacco. Para o estudioso, o espaço midiático, segundo estratégias de oferta e demanda, redistribui os produtos dessas comunidades, que são atribuídos a determinados gêneros. Nós cremos que, mais do que estratégias, atuam relações de forças das quais a mídia é partícipe como fator político. Por isso, como o mostram os muitos casos na história da passagem do popular (quer como música, teatro, narração, ou informação pública) para a mídia (STEIMBERG, 1998) com o desenvolvimento da 
cultura de massa ${ }^{7}$, a percepção social de um gênero se modifica e se completa ao começar a ser reproduzido e circular nesses domínios. Essa circulação também se relaciona ao papel sociohistórico do gênero.

Assim, mais do que “comunidades” em relação com uma mídia guiada pela oferta e demanda de um suposto mercado livre, nos parece adequada a visão de um espaço social de forças em conflito, como a que encontramos em Bourdieu ([1976] 2003 e [1971] 2010). Dessa teorização provém a noção de "campos", espaços estruturados de posições desiguais em relação a uma prática. A entrada de determinado gênero nos modos contemporâneos de reprodução e circulação que atribuímos à cultura de massa, como também seu desenvolvimento em qualquer tipo de espaço institucional, mesmo não midiático, faz com que ele participe de um ou mais subcampos: político, educacional, de produção de bens simbólicos, ou das mediações entre esses e outros, conforme a prática social em que se insere. Principalmente na produção e circulação de bens simbólicos, há muitos casos em que um determinado gênero chega a constituir em torno de si um subcampo conformado pela sua crítica, seu público, e por diferentes formas de institucionalização e consagração ${ }^{8}$.

Como veremos no próximo capítulo, a consolidação do que depois se denominaria "rock argentino" é um caso praticamente laboratorial desse processo de conformação de um gênero-campo. Principalmente no período que localizamos nesta pesquisa, no qual, devido à sua condição relativamente periférica em relação ao mercado e a uma série de fatores políticos que serão abordados oportunamente, é possível perceber, nele, o "efeito de série" a que nos referimos em 2. Porém, e contraditoriamente, as vozes que nele se percebem não obtêm sua orientação dialógica nos limites do gênero-campo, mas pela relação com um interdiscurso. A regularização não é explicável sem atender aos processos parafrásticos que a vinculam, como veremos a partir dos capítulos III e IV, com espaços que são descontínuos, tanto entre si quanto em relação ao gênero-campo: as vulgatas de diversas fases do pensamento existencialista e do marxismo no campo cultural argentino da época, a preeminência que ganham alguns objetos tidos como "evidência" nos saberes desse campo, expressões muito anteriores do drama e da canção popular urbana, dentre

\footnotetext{
${ }^{7}$ No capítulo próximo especificaremos o alcance que daremos à denominação “cultura de massa” nesta tese.

${ }^{8} \mathrm{Na}$ música urbana de tradição popular do século XX há vários exemplos, alguns expandidos por diversos países, como a “cumbia” (FERNÁNDEZ L'HOESTE e VILA, 2013) ou “chamamé” (HIGA, 2010), outros relacionados a um espaço nacional, como o samba brasileiro ou o tango argentino nos seus períodos de consolidação e entrada na mídia radiofônica (MENEZES, 2012).
} 
outras filiações. Inclusive as configurações predominantes para as vozes e perspectivas no jogo enunciativo, e o conjunto dos traços estilísticos recorrentes no gênero-campo, todos fatores que intervêm de um modo não evidente na sua própria identificabilidade no espaço social, parecem ganhar coerência nessas relações interdiscursivas. Elas têm a ver muito mais com a dimensão sociohistórica do gênero, com o confronto que lhe deu lugar no campo da produção de bens simbólicos, do que com a configuração formal dos “exemplares" que nele são localizados.

\section{A dimensão sonora}

Abordar, como faremos nesta tese, séries discursivas que incluam canções traz, para o pesquisador, a necessidade de tomar decisões que afetam não apenas a metodologia, mas a própria delimitação do objeto. Já enfrentamos essa necessidade em desenvolvimentos anteriores, e neste item explicaremos o caminho que seguiremos nesta ocasião, em que formulamos nosso trabalho até agora mais abrangente com esse tipo de corpus. A canção é uma materialidade que combina a linguagem verbal com a musical, e nossa abordagem é a partir de um campo disciplinar configurado principalmente em torno da linguagem verbal. O que fazer, então?

Sabemos que muitos trabalhos sobre a canção têm sido desenvolvidos, em diversas áreas das humanidades, como a Sociologia, as Ciências da Comunicação e inclusive as ciências da linguagem, focalizando exclusivamente as "letras", como textos, ou inclusive como espaço para levantamento de temáticas e de referência a objetos diversos. Não negamos que, dependendo dos objetivos traçados, possam ser atingidos, dessa maneira, resultados reveladores, como o mostra a leitura de alguns textos que, inclusive, fazem parte da nossa bibliografia, como Blanco e Scaricaciottoli (2014), Conde (2007) ou Manzano (2010). Porém, definitivamente não é essa nossa opção, porque cremos que, para os objetivos que formulamos na nossa pesquisa, bem como para o tipo de abordagem discursiva materialista que promovemos, diferentes aspectos da dimensão sonora podem e devem ser integrados. Volta, então, a interrogação: quais e como?

Comecemos por estabelecer que não vemos uma "supremacia" intrínseca de uma dimensão (verbal ou musical) sobre a outra na produção de sentido na canção. Benveniste ([1969] 2002, p 47-69) propõe que as unidades da música não designam, e que isso a 
diferencia do sistema linguístico, que exerceria um modelado semiótico sobre todos os outros sistemas, sendo o "interpretante" da sociedade. Entendemos que essa comparação aponta a que é por meio da linguagem verbal que podemos tratar sobre as outras, mas não cremos que disso se depreenda que a "letra" de uma canção interpreta ou dá sentido à música. Concordamos, portanto, com Frith ([1998] 2014) em que "La cuestión no es sentido (letra) versus ausencia de sentido (música), sino la relación entre los dos tipos de producción de sentido, la tensión y el conflicto entre ellos." Ou, como propõe Sousa (2011, p 114) "a canção como modo linguística e musicalmente imbricado de fazer sentido". Nessa imbricação, consideraremos primeiramente a problemática da voz, para passar depois a fenômenos do ordenamento sequencial e do reconhecimento de gêneros que pensamos que podem ser atendidos na prática de análise.

A articulação dos diversos níveis de "voz" enunciadora com a interpretação vocal do canto é abordada amplamente por Frith ([1998] 2014), quem distingue três dimensões para considerar:

Las palabras, que parecen darles a las canciones una suerte de significación semántica autónoma; la retórica, palabras usadas de manera especial, de manera musical, una forma que llama la atención sobre aspectos y problemas discursivos; y las voces, palabras habladas o cantadas con tonos humanos que son en sí mismos "significativos", signo de una persona y de una personalidad. (FRITH,[1998] 2014, p 284, grifo no original).

Frith vai mostrando que aquilo que ele denomina "retórica", e que no trecho que citamos reformula como uma "maneira musical" de empregar a palavra, corresponde a relações especiais com a oralidade, que entram em tensão com a modalidade escrita à qual podem remeter determinados momentos estilísticos das letras. O autor considera, como alguns dos estudiosos da "palavra cantada" (por exemplo, MATOS, 2001), que a canção adota o ritmo da fala e que isso a aproxima dos gêneros dramáticos, relação esperável, considerando o longo vínculo histórico entre canto e dramatização. Por esse motivo, todos esses estudiosos dão o nome de "performance" à interpretação vocal. A relação com a teatralidade é mais nítida em composições nas quais uma personagem é apresentada, interpelada ou auto-apresentada pelo canto do intérprete, mas mesmo quando não há essa focalização explícita, os estilos de fala remetem a determinados caracteres. Também 
Colomba (2010, p 32) propõe que no plano retórico da voz "suas qualidades sonoras produzem associações relativamente convencionais".

Cremos que esse processo de remissões pode articular-se, na análise, por um lado, com a conceitualização do locutor como lugar social de dizer, que referimos em 2 a partir de Guimarães (2005), sobrepondo, na performance da mesma voz, os lugares dados no mundo representado na canção e o lugar de locutor-cantor dado pela canção -e, no caso, pelo cantar no campo específico que abordamos- como prática discursiva. E, por outro lado, as remissões também levam para diversos tipos de divisão do linguístico, significando lugares na desigualdade social e na produção de identidades grupais.

Cremos que não menos importantes, e também possíveis para uma abordagem discursiva, são diversos fenômenos no fio do discurso que relacionam a letra com aspectos da dimensão sonora, e que incluiremos em muitas das nossas análises. Em um trabalho relativamente recente de Souza (2011), vemos alguns modos de integração das dimensões verbais e sonora na observação de canções que podemos relacionar aos que aqui desenvolveremos. Não é esse o único artigo em que o autor trata sobre a problemática do canto em relação à enunciação e ao discurso, mas interessou-nos especialmente porque ele tem como matéria principal uma série específica de canções abordadas comparativamente. Trata-se de músicas compostas e gravadas em diferentes épocas e que têm como objeto a cidade de São Paulo ${ }^{9}$. Ao referir-se ao "encadeamento sintático e enunciativo" na especificidade na canção, o autor afirma que

\footnotetext{
Fica assim valendo não apenas os pontos de ligação entre um termo e outro na cadeia da fala, mas sobretudo os pontos vocálicos, consonantais ou entonacionais sobre os quais a voz se detém, prolongando não só o ato de vocalizar, mas também abrindo as possibilidades de fazer sentido. Disso é que se trata na canção ou no contato entre a fala e o canto em um mesmo evento enunciativo. (SOUZA, 2011, p 114-115)
}

Assim, por exemplo, ao abordar a valsa "Lampião de gás" na gravação de Inezita Barroso, o autor observa que as rimas no refrão da valsa "fazem desaparecer os objetos que designam na mesma medida em que evolui a melodia da canção" (ibidem, p 116). Ou, na análise que desenvolve de "Ronda", dentre outras observações sobre a estruturação melódica e narrativa da canção, aponta que as frases que iniciam as estrofes $1^{\mathrm{a}}$ e $3^{\mathrm{a}}$ têm

\footnotetext{
9 "Ronda", de Paulo Vanzolini; "Perfil de São Paulo", de Bezerra de Menezes; "Lampião de gás”, de Zik a Bergami, e "Sampa" de Caetano Veloso.
} 
identidade melódica e rítmica, repetição para a qual encontra correlato na narração. No nosso trabalho fazemos observações análogas, sobre paralelismos que comportam melodia e algum tipo de indicador na letra, na abordagem de várias gravações.

Da mesma maneira, e sem antecipar um inventário, apenas a título de exemplo, integramos na análise, além desse tipo de correspondências, prolongações silábicas no canto, ecos, mudanças na velocidade do canto ou no volume da voz, a passagem e a diferença entre canto e recitação, a entrada de instrumentos quando lhe encontramos relação com o que se canta. Também a irrupção ou citação de outros gêneros musicais, performances próprias de gêneros que integram música e drama (sketch de café-concert, teatro infantil), ou de gêneros não musicais (liturgia, arenga de agitação), elementos sonoros extramusicais (assobios, respiração, batidas, murmúrios, mar, vento, sirenes policiais).

Evidentemente, considerando que damos atenção a todos esses elementos na análise, não podemos dizer que nosso trabalho é sobre "letras", como se fosse a mesma coisa que operar com uma série de transcrições. Isso não impede afirmar, também, que os objetivos do nosso trabalho, na medida em que ele aborda processos de regularização como explicados nos itens anteriores, dizem respeito principalmente à materialidade verbal. Não está entre os nossos objetivos uma reflexão teórica específica sobre o canto em relação a categorias do discurso, ou sobre o cantor ou o músico como lugares socais de dizer. Inclusive, integramos, em pontos chave da nossa reflexão, textos verbais não musicais: o Capítulo V se articula em torno da análise de um encarte de disco e de um curta-metragem, no Capítulo VII também um encarte é parte importante da análise, no Capítulo IX acontece algo análogo com um poema, e nos IV e VIII com depoimentos de músicos. Dado que estabelecemos relações parafrásticas entre enunciados dessa natureza e as canções, é claro que o verbal está no nosso foco. Mas ele não chega ao nosso trabalho como se existisse por si, e, no decorrer das análises resultará claro que, em muitos casos, a atenção aos elementos sonoros que elencamos no parágrafo anterior direcionou nossa interpretação, que teria sido inviável, ou seria outra, sem eles.

Por último, cremos necessário que os modos de execução e de escuta que o gênero propiciou na sua inserção sociohistórica tenham um correlato no dispositivo enunciativo de análise do qual tratamos no item 2. Preferimos abordar esse problema neste item e não naquele porque envolve necessariamente a voz na dimensão em que a localiza Frith na citação que trouxemos parágrafos atrás: "palabras habladas o cantadas con tonos humanos 
que son en sí mismo 'significativos', signo de una persona y de una personalidade". Assim, a voz significa um corpo, e cremos que o conceito de "incorporação" como o formula Maingueneau (2001, p 149), constituição de um corpo, o da comunidade imaginária que participa da fruição da obra, pode nos levar a pensar em um corpo da escuta, correlativo àquele da voz. Esse corpo é solicitado nas formas relativamente ritualizadas de escuta da gravação (individuas ou coletivas) e do recital, daí uma latente intercambiabilidade com o da voz. Solicitado ao movimento -não necessariamente à dança- já que o corpo, no campo do rock no mundo, mesmo em formas difusas e de canção, resulta "la epifania misma del conflicto" (MONTELEONE, 1992, p 30). E ainda solicitado ao canto e à réplica sonora, pelas próprias condições de circulação da canção e pela intercambiabilidade de papéis com o corpo da voz, que acabamos de mencionar.

\section{Encerramento}

Desenvolvemos, neste capítulo, uma apresentação e explicação de nosso posicionamento teórico-metodológico, e de boa parte do dispositivo analítico com o qual abordaremos a discursividade nas primeiras épocas do denominado "rock argentino". Alguns conceitos ainda serão introduzidos no decorrer das análises e das reflexões dos capítulos posteriores. É necessário, agora, introduzir e apresentar ao leitor o que é que se delimita como "rock argentino" nesse subcampo da música de tradição popular, as conjunturas sócio-histórico-culturais em que esse processo se desenvolve, e como nossa pesquisa se articula em torno dele. Disso trata o capítulo próximo. 


\section{Capítulo II \\ O denominado "rock argentino" e a nossa pesquisa}

Este capítulo estará dedicado a situar nosso principal objeto de estudo, o denominado "rock argentino", em duas dimensões. Por uma parte, nas condições sóciohistóricas nas quais ele começa a ter lugar em um determinado espaço nacional e em um momento histórico. Por outro, e como uma dimensão não separada da anterior, na sua conformação como uma série de práticas discursivas que foi sendo identificada como um campo específico dentro da cultura de massa. Para tanto, começaremos por apresentar alguns traços gerais da situação política e cultural da Argentina na década de 1960 e no início da década seguinte, panorama que será retomado com mais detalhe e focalizando alguns problemas particulares nos capítulos IV e VIII. Depois, passaremos a explicar como entenderemos, neste trabalho, noções como "cultura de massa", "campo", e as especificações "música de tradição popular" e "música para escutar" nas condições de produção e circulação do século XX em diante. Logo passaremos para a delimitação, nesse quadro, do que iria ser denominado como "rock argentino", apresentando inclusive as outras denominações que foi recebendo no seu desenvolvimento. Situados o fenômeno e sua inserção, passaremos para um interrogante metodológico crucial para um trabalho que, como o nosso, tem como propósito indagar relações interdiscursivas: em que medida o confronto ideológico no campo intelectual e no campo político pode determinar filiações e tendências em um campo da produção cultural relativamente distante desses debates e, sobretudo, situado em um lugar quase periférico? Isso implicará, por um lado, levar em conta as características da desigualdade e da circulação de bens culturais na Argentina da época e, por outro, o que tem sido investigado acerca dos efetivos contatos entre grupos de intelectuais, artistas e coletivos de diverso tipo, desnaturalizando relatos construídos por esses mesmos setores. Seguidamente explicaremos os critérios que estabelecemos para a delimitação do corpus desta tese e quais serão os objetos que focalizaremos dentro dele. Por último, daremos indicações sobre os Apêndices que acompanham esta tese em pasta aparte, para facilitar sua utilização pelos leitores. 


\section{Um questionamento em todas as ordens}

O início da década de 1960 encontra uma Argentina com indicadores socioeconômicos relativamente positivos no panorama mundial. Aroskind (2003, p 6566) aponta que sua taxa de crescimento demográfico se aproximava mais à dos países industrializados do que à dos outros da América do Sul, e que a Argentina mostrava indicadores de saúde, educação, esperança de vida e produção científica “considerablemente más elevados que el resto de América Latina”. O mesmo pesquisador expõe, ainda, dados de emprego que evidenciam uma situação de crescimento constante. A desigualdade na distribuição de renda era também muito menor que a do resto da região. Segundo Fausto e Devoto (2004, p 361), considerando o "coeficiente de Gini (onde 0 significa ausência de desigualdade e 1, o máximo de desigualdade)", Argentina tinha 0.41 em 1961 (o Brasil tinha 0.57), e a taxa de analfabetismo tinha caído de 12\% em 1950 (que já era baixa para a região) para 9\% em 1960.

No entanto, a leitura desses autores e de outros como Gordillo (2003) evidencia que a preservação dessa desigualdade relativamente baixa dependeu de constantes enfretamentos e conflitos trabalhistas, e se deu em um período marcado, de modo geral, pela instabilidade política e por uma crescente desconformidade, que começou nos setores operários e foi incluindo as classes médias urbanas. O derrocamento de Perón em 1955 tinha dado lugar a um regime que se encaminhou rapidamente para o autoritarismo. As eleições de 1958 se deram com o peronismo proscrito, e. no ano seguinte, o próprio governo eleito, de Arturo Fondizi, estabelece o estado de sítio para reprimir uma onda de greves ${ }^{10}$, o que levou à detenção de milhares de pessoas e à proscrição de outros partidos, além do peronismo (TEACH, 2003, p 34-35). O próprio Frondizi acaba derrubado por um levantamento militar, e as eleições de 1963 se realizam novamente com a proscrição do peronismo, dando lugar a um governo fraquíssimo, o de Arturo Illia, eleito com apenas $25 \%$ dos votos.

É também um período de grande criatividade, expansão e inovação na produção cultural e na participação política. Por uma parte, Argentina será também cenário de um processo internacional de mudança dado pelo que Terán (2008, p 275) caracteriza como uma nova configuração de sensibilidades, crenças e valores, que dá lugar a diversas

\footnotetext{
${ }^{10}$ No mesmo ano da Revolução Cubana, a medida repressiva, conhecida como plano "CONINTES" (Conmoción Interna del Estado) já mostrava, na sua denominação, a circulação das doutrinas de "segurança interna" que caracterizaram a Guerra Fria e a intervenção estadunidense na América Latina.
} 
expressões renovadoras e questionadoras em todos os âmbitos da produção artística e cultural. Experiências consideradas de vanguarda se desenvolvem na Europa, nos E. U. e na América Latina no cinema, teatro, plástica, música e outros campos de práticas considerados "menores", como as HQ ou formas derivadas do music-hall. Colomba (2010, p 34), a partir do conceito de "caráter social” de Raimond Williams (2003), identifica a forte presença, no mundo e na cultura argentina, de um "caráter social alternativo" de amplíssimo alcance, "fortemente iconoclasta e renovador". Uma região do centro de Buenos Aires que concentrava centros culturais, livrarias e teatros foi cenário de práticas inovadoras e experimentais, como happenings, arte pop e arte multimídia, em sintonia com expressões que se davam em outras capitais do continente e da Europa. Um dos principais centros de produção e divulgação foi o Instituto Di Tella, fundado em 1958, e sobretudo seu Centro de Artes Visuales, que funcionou de 1963 a 1969. Por ele passariam, apresentando sua obra ou participando de encontros e oficinas, inúmeros artistas, já profissionalizados ou em formação, inclusive, como veremos, vários futuros roqueiros.

Na produção de conhecimento, as mudanças não são menores. Já em 1963, Oscar Masotta oferece os primeiros seminários sobre Lacan ${ }^{11}$. Novas disciplinas transformam os estudos de humanidades, e a Sociologia se consolida como departamento -fundado em 1957- e como curso na Universidad de Buenos Aires, sob a direção de Gino Germani, com uma orientação para o estudo dos papéis da comunicação social na formação das ideologias e da "orientação política dos atores" (BLANCO, 1999, p 20). Também terá foco na dimensão política a renovação que se dará na Filosofia, com centro na recepção do existencialismo sartreano (TERÁN, 1991, p 17), processo sobre o qual trataremos com mais detalhe no Capítulo IV, pela relevância que vemos na sua relação mediada com as discursividades que abordamos. Diversas variantes do que Terán caracteriza como um humanismo materialista vão ganhando espaço, já na segunda metade da década de 1950, como reação contra o que viam como um "espriritualismo" dominante nos estudos acadêmicos nessa área (ibidem, p 18). A nova intelectualidade vai produzindo também revistas culturais e literárias que serão importantes registros desse processo. Vale a pena determo-nos em uma síntese do panorama que o autor descreve:

\footnotetext{
${ }^{11}$ No caso, não foi na universidade, que demorou para incorporar a Psicanálise, mas na denominada Escuela Pichon Riviere de Psiquiatria Social (LONGONI, 2004, p 7).
} 
Cerrando un círculo, esta concepción haría de su ahincada tematización de las cuestiones político-sociales una suerte de programa alternativo dentro de la disciplina filosófica, y si es en nombre del espíritu como se ha pretendido enmascarar la realidad y eludir esa piedra de toque de la política, en alguna de sus derivaciones -como la ejemplarmente representada por el grupo de la revista Contorno- se diseñará una ideología que en rechazo del espiritualismo liberal construyó una concepción corporalista (con una oposición análoga a lo que Sartre en un conocido artículo había llamado "la maloliente salmuera del espíritu") y al mismo tiempo fuertemente historicizada, así como encuadrada -al igual que la propia producción sartreana- en una visión de la política que la torna atendible cuando a través de ella se generan situaciones que confrontan a los individuos con los límites de conductas fuertemente moralizadas. Dentro de otro registro que compatibilizaba estas creencias con las provenientes del nacional-populismo y de una lectura economicista del marxismo, Hernández Arregui resolverá asimismo las crisis del espíritu en la del imperialismo, y a la misma moral en la política. (TERÁN, 1991, p 2021)

A referência, no excerto transcrito, a uma confluência entre o pensamento contestatário e o "nacional-populismo" se relaciona a um processo crucial no campo político da época. Se bem boa parte das organizações políticas mantém sua identidade, há um deslocamento de setores amplos das classes médias para o peronismo, ou, quanto menos, para um abandono do anti-peronismo (CARASSAI, 2014). Os governos baseados na proscrição do peronismo vão perdendo legitimidade, e setores de esquerda intelectual e estudantil que tinham sido anti-peronistas começam a ver esse movimento de outra maneira, como espaço de confluência possível com os setores populares (ALTAMIRANO, 1992). As políticas dos governos anti-peronistas, de aberto alinhamento com os Estados Unidos e de abertura da economia a interesses estrangeiros, com medidas que começam a prejudicar inclusive os setores médios, completam o quadro para essa reconfiguração. Vai surgindo uma esquerda nacionalista que se aproxima do peronismo, processo que dará lugar à formação de uma juventude peronista de esquerda que terá papel central na radicalização do final da década, e dos 70. E cresce, também, a influência da esquerda tradicional nos artistas e intelectuais, potencializada por um fato que ganhará a atenção de uma geração, e que estará no centro da discussão sobre suas práticas políticas: a Revolução Cubana de 1959.

A relação dessa esquerda -"Nueva Izquierda", segundo denominações que encontramos em Longoni (2004) e Terán (1991)- com as vanguardas artísticas da época será conflitante. Em um ensaio sobre os intelectuais argentinos nos 60, Silvia Sigal se refere a essa contradição: 
La intelectualidad crítica en gestación no recibió de manera unánimemente favorable las mutaciones culturales, lejos de ello. La evolución de los intelectuales argentinos estuvo marcada por una doble tendencia, de radicalización política y conservadurismo cultural. (SIGAL, 2002, p 158)

Essa tendência não se manifestou em intelectuais como Masotta, Roberto Jacoby e outros, que, como veremos no Capitulo IV, participaram tanto da vanguarda artística quanto da militância, mas, levando em conta o que encontramos no material levantado e lido da época e sobre ela, concordamos com Sigal em que a aversão da esquerda pelas práticas artísticas inovadoras foi predominante. O pesquisador estadunidense John King, que estudou profusamente a atividade do Instituto D Tella, aponta que, para a visão que resultava hegemônica na esquerda, "el arte debería ser realista, nacionalista y comprometido, en contraposición a los universalistas, coloniales, extranjerizantes e inanes movimientos de vanguardia" (KING, 1985, p 32). Verdadeiramente, expressões do teatro independente a cargo de escolas de atores ligados à esquerda tradicional tinham uma tônica e um repertório reconhecido como "realista" porque, em palavras de um deles, o dramaturgo e contista Germán Rozenmacher, propunham-se a "desmitificar nuestra realidad a partir del lenguaje" (ibidem, p 61). Não é difícil imaginar o receio que provocava, nessas condições, a música apoiada em ritmos e gêneros de origem anglosaxã. De fato, todos os estudiosos e críticos do rock argentino que referiremos nesta tese coincidem em apontar que a esquerda, intelectual ou não, teve, no início, uma forte rejeição pela musicalidade ligada ao campo do rock no mundo ${ }^{12}$, e foi indiferente ou hostil em relação às primeiras expressões do que deviria em rock nacional. Como veremos na Capítulo VIII, no início dos 70 essa atitude mudaria parcialmente.

Um último fator a ser levado em conta neste breve panorama da Argentina da época é que essa efervescência política e cultural coexistia com uma reação do mais conservador da sociedade, o que Terán (1991, p 163-167) denomina "bloqueo tradicionalista". O nacionalismo católico tinha expressão em grupos de classe média e empresariais, e era forte entre os militares, que naquele tempo ocupavam um espaço importante na política, mesmo quando não estavam diretamente no governo. Revistas de extrema direita denunciavam o que viam como depravação nas novas formas artísticas, e

\footnotetext{
${ }^{12}$ Com detalhes pitorescos, como uma cartilha do Partido Comunista Argentino, em 1962, que recomendava aos militantes não dançar twist (MANZANO, 2010).
} 
alguns grupos atacavam diretamente apresentações e locais de espetáculos. Esses setores encontraram, de fato, um aliado instável na intervenção estadunidense sobre o continente, que influenciava o empresariado e as forças armadas, sobretudo depois da Revolução Cubana, com sua prédica anti-comunista sobre o "inimigo interno". O golpe militar de 1966, conhecido como "Revolución Argentina", e que levou ao poder o general Juan Carlos Onganía, inclui, na sua heterogênea composição, algo desses setores. As universidades nacionais foram intervindas, o que provocou a renúncia de muitos professores, e começou uma censura mais intensa sobre expressões culturais. A maior repressão e as políticas de endurecimento em relação ao sindicalismo foram levando a uma crescente resistência.

Tal é o panorama que apresentamos como primeira descrição das condições políticas e culturais em que se delimita o subcampo da música de tradição popular que será nosso objeto. Antes de passar a explicar sua delimitação, esclareceremos o emprego de algumas categorias para tratar sobre a música nas condições de circulação e reprodução próprias do século XX, que em alguma medida ainda continuam.

\section{Música, reprodução e cultura de massa}

Ao longo desta tese empregaremos, tanto para o rock argentino como para outros agrupamentos, a denominação “de tradição popular” e não simplesmente "popular". Explicar essa decisão implica algumas considerações sobre como compreenderemos, nesta tese, a produção, reprodução e circulação de bens simbólicos na contemporaneidade.

Partimos de reconhecer que há, no século XX, gêneros e tipologias discursivas que se caracterizam por um modo de recepção coletivo crescentemente midiatizado e pela reprodutibilidade mais ou menos seriada, conforme sua adoção ou não pela indústria cultural, que contribui para sua transformação. Cremos que o modo de recepção dessas produções não é passivo nem necessariamente homogêneo, como era visto por alguns representantes da escola de Frankfurt, como Horkheimer e Adorno ([1944] 1994). Consideraremos, de acordo com Martín-Barbero (2008: 173-175), a cultura de massa como o modo de existência do popular nas condições de reprodutibilidade e urbanização 
que se desenvolvem a partir da segunda metade do século XIX, e com especial vigor ao longo do século XX. Para o mesmo autor (idem, p 131) essa cultura de massa se configura e transforma nos processos de luta pela hegemonia "no espaço histórico dos deslocamentos da legitimidade social", o que implica não reduzi-la à dimensão tecnológica de desenvolvimento das mídias nem assimilá-la a uma suposta "degradação" da cultura.

Não empregamos, por outra parte, o termo "cultura popular", que nos parece relacionado a etapas históricas prévias aos modos atuais de reprodução e a uma cisão anacrônica entre o "popular" e o "ilustrado". Concordarmos com enfoques como os de Steimberg e Traversa (1997, p 15-17), que consideram que o modo de produção próprio das culturas tradicionais orais se descaracterizou definitivamente como resultado da passagem à mídia dos gêneros que as constituíam e da intensa interação entre gêneros “altos" e "baixos". Inclusive Bourdieu ([1971] 2010), ao diferenciar, no mercado de bens simbólicos, um "campo de produção restringida" e um "campo de grande produção" onde se localizam todos os gêneros e modalidades que abordaremos nesta tese, aponta hierarquias do gosto dentro dessa "grande produção", orientadas pela assimilação, por diferentes vias, com a produção restringida das obras eruditas. Diferentes graus de autonomia a respeito das demandas da indústria cultural e do "uso" para outras finalidades estariam na base de algumas dessas hierarquias.

A questão do "uso social” leva justamente para a problemática que nos faz adotar a denominação de "música de tradição popular". Ela é proposta por Fischerman (2013), quem diferencia, dentro da música não erudita dos séculos XX e XXI, habitualmente denominada "popular", um segmento caracterizado pela complexidade como valor compartilhado pelos seus produtores e ouvintes, e por enunciar-se e perceber-se como destinado principalmente à escuta e secundariamente (ou nulamente, conforme o caso) a usos como o baile, a comemoração, e outros tipos de práticas ritualizadas. Historicamente, foi a aparição da gravação fonográfica e sua reprodução a que possibilitou o surgimento e diversificação desse segmento, porque ampliou a perdurabilidade do que antes se executava para usos festivos e outras práticas, sem ser escutado apenas como música. Ao ficar gravado, matizes começam a ser percebidos com mais nitidez, estimulando a imaginação compositora no sentido de uma maior elaboração: 
Mucho del tango, del jazz, gran parte de la música brasileña posterior a la década de 1960, los desarrollos del modelo de la canción pop articulados por los Beatles, el muchas veces ridiculizado rock progresivo, la canción política y las derivaciones de los movimientos reivindicativos del folklore, conforman un grupo de músicas que, más allá de sus funcionalidades sociales, se escuchan como música. (FISCHERMAN, 2013, p 24).

Essas expressões musicais, nas quais se incluem as que são objeto da nossa pesquisa, são de tradição popular por não provirem da tradição erudita, mas adotam, em diversas medidas e com desigual sucesso, valores como o da complexidade compositiva, a procura de inovação, e a legitimação de servirem, por si mesmas, para a escuta e a fruição; valores todos que as aproximam dos que dão sustentação aos modelos eruditos, ou que, quanto menos, as distanciam das funcionalidades atribuídas ao "popular". Seu florescimento no mundo, quase sempre partindo de formas "populares" em sentido estrito, se explica pelas possibilidades de gravação e reprodução que já apontamos, pelo crescimento de um público urbano escolarizado, com maior acesso aos bens culturais e do qual também surgem produtores de nova música; enfim, pelas mesmas condições que ocasionam o próprio surgimento e expansão do mercado de bens simbólicos.

Assim, para essas correntes, o propósito de complexidade e criatividade no musical e no poético, por uma parte, e, por outra, a possibilidade de gravação e reprodução que lhes dá origem, constituem uma contradição de base que ocasiona uma relação tensa com a indústria cultural. Respondem a uma demanda de público que quer algo diferente do mais vulgar e serializado, mas para chegar a ele precisaram historicamente da indústria que tende à serialização.

\section{O "rock argentino" e sua inserção na conflituosidade}

Vemos o que se denominou "rock argentino" como um agrupamento de práticas discursivas na música de tradição popular. Parte do que desenvolveremos neste item terá a ver com a possibilidade de caracterizá-lo como "gênero", questão que nos parece relativamente secundária em função de duas preocupações principais: para diferenciar-se do que, em oposição ao que é que esse agrupamento vai sendo delimitado em determinado 
espaço da produção musical, e como ele se estabiliza e consolida em uma relativa institucionalização, ganhando, nesse caminho, determinados nomes.

\subsection{Uma primeira delimitação dissidente}

Comecemos por dizer que o incipiente "rock argentino" se delimita, de início, como um claríssimo exemplo do último que explicamos no item anterior: música para escutar. Mesmo no seus mais iniciais e rudimentares desenvolvimentos, quando ainda estava longe da complexidade que algumas das suas expressões rapidamente atingiriam, a tentativa era essa. Como explica Díaz (2005), ele vai diferenciando-se, em meados dos anos 60 , do espaço da "música para jovens" que a indústria cultural promovia mediante a produção discográfica e os programas radiais e televisivos. Alguns jovens de origem maioritariamente da classe média não abastada, mas também alguns de setores um pouco mais humildes, de uma Argentina ainda, como vimos, com muita mobilidade social, começam a tentar produzir uma música precisamente "para escutar", não destinada ao baile nem ao divertimento. Uma procura de maior elaboração no musical e nas letras, que, por sua vez, deixariam de ter como tópico a exaltação de felicidade e do conformismo que funcionava como imperativo nas produções da indústria discográfica (ÁBALOS, 2009, p 28), foi tecendo uma rede de diferenciação e dando lugar ao surgimento de bandas pioneiras e solistas que se reúnem em alguns bares e pubs da região central de Buenos Aires. No início, praticamente eles não obtêm qualquer espaço na mídia radiofônica, muito menos televisiva, e, de modo geral, são rejeitados pelas discográficas.

Vários dos críticos e historiadores que referimos nesta tese localizam, nas décadas de 1950 e 1960, a formação de uma indústria de consumos juvenis, determinada por uma combinação de necessidades de mercado com a irrupção de um segmento etário em práticas que o nucleiam de diversas maneiras conforme a estratificação social. Argentina não ficou de forma desse processo. A música "para jovens" que promovia a indústria cultural teve como uma das suas primeiras tentativas o deslocamento direto das formas menos agressivas do rock'n roll em inglês, mas em torno de 1962-1963 começa a desenvolver uma estratégia diferente, de produzir música “jovem” em espanhol, alternando sonoridade própria do twist ou do rock'n roll com ritmos do repertório romântico-melódico. Assim é lançado ao mercado um conjunto de produções conhecido 
como "Nueva Ola", nome dado pela indústria, do qual derivará o adjetivo "nuevaolero" para caracterizar, por vezes pejorativamente, seus cantores e seus consumidores (MANZANO, 2010). A expressão de mais alcance da "Nueva Ola" foi o denominado “Club del Clan”, grupo de jovens cantores e cantoras que foi também, e de início, um programa de TV. Tanto o Club del Clan quanto outras produções na mesma linha expunham um estereotipo de jovem que, embora portasse uma rebeldia "saudável", não questionava nenhum aspecto do ordenamento institucional, e, entre diversão e algumas travessuras, integrava-se às expectativas de progresso social e de consumo.

Aqueles que interrogaram o surgimento do que depois seria denominado "rock nacional" em relação com o contexto sociocultural, localizam o fenômeno como uma dentre diversas "rupturas" e "reações" que, como vimos no item anterior, caracterizaram o campo cultural e o campo intelectual na época. E ele é parte, mesmo que periférica, dessa renovação questionadora. Esse novo espaço que será o "rock local” se constitui, em boa medida, como ruptura com a música "jovem", "nuevaolera", promovida pela indústria discográfica no país. Concordamos plenamente com Alabarces (1993, p 42, grifo no original) quando afirma que "El rock nacional, o lo que hoy habituamos llamar rock nacional, se instala contra el Club del Clan y sus clones". E acrescentamos que a ruptura se estende a outras modalidades que também tinha tentado a indústria cultural, já que um traço distintivo das práticas desse setor de músicos foi compor e cantar em espanhol. Mesmo alguns deles que, como veremos no Capítulo III, tinham dado seus primeiros passos na música replicando canções em inglês, adotaram o espanhol de modo praticamente definitivo.

Colomba (2010, p 34) vê o que deviria em "rock argentino" como uma das expressões do "caráter social alternativo" na cultura argentina, que comentamos no item anterior:

El rock nacional parece identificarse en sus orígenes sesentistas con los rasgos más sobresalientes de uno de esos caracteres sociales alternativos, que se expresa también a través del ensayismo nacional, las nuevas ciencias sociales, el cine de autor, el music hall, la renovación del humor gráfico, entre otras manifestaciones artísticas e intelectuales, y que tiene, entre sus rasgos esenciales, un fuerte carácter iconoclasta e impugnador.

Analogamente, Díaz (2005, p 31) localiza o surgimento do rock argentino dentro de uma "crise de hegemonia" que afeta, na década de 60, as relações entre os diferentes 
campos da produção cultural, o que inclui a legitimação de campos de menos prestígio dentro dessa produção. O pesquisador localiza nessa nova corrente musical uma constante discursiva que denomina como "diferença dissidente" (ibidem, p 164) e que o relaciona a outras expressões de vanguarda.

\subsection{Gênero? Movimento? Campo? As aderências do nome "rock"}

O primeiro trabalho publicado na pesquisa argentina sobre o rock do país é de 1985, vinte anos depois dos inícios, o que dá uma ideia do quanto ele demorou para ser objeto de interesse acadêmico. Era um ensaio na área da Sociologia, e como capítulo de um livro denominado Los nuevos movimentos sociales. O texto, de autoria de Pablo Vila (1985), tinha como título "Rock nacional. Crónicas de la resistencia juvenil”. O rock argentino era, nele, caracterizado como "movimento" em função do papel aglutinador que os recitais tinham cumprido em um período posterior ao que abrange esta tese: os últimos anos da ditadura cívico-militar de 1976-1983. De fato, com "movimento", Vila se referia não apenas aos músicos mas também ao seu público juvenil e ao conjunto de práticas em que eles construíam um espaço identitário. Do nosso ponto de vista, o emprego do termo é muito datado naquela conjuntura especifica. De fato, a maior parte do tex to tratava sobre o período ditatorial e sobre a transição democrática em andamento, e o próprio Vila não empregou a denominação "movimento" em trabalhos sobre o rock argentino em outros períodos.

No entanto, um texto imediatamente posterior do mesmo autor (VILA, 1987), poria em evidência uma dificuldade classificatória que pode ter motivado o termo "movimento" em alguns textos críticos e em setores do jornalismo ligado ao rock. Era muito duvidoso caracterizar como "gênero" tudo aquilo que, já na década de 80 , tinha ficado sob o nome de "rock nacional". Uma concepção dos gêneros baseada em regularidades composicionais e estilísticas com certeza não agruparia todos esses fenômenos sob um mesmo nome, menos ainda levando em conta as denominações estabilizadas para gêneros musicais. O próprio nome "rock" parecia e parece questionável, já que o agrupamento incluiu, desde seus primeiros anos, como poderá apreciar-se ao ouvir as composições que incluímos nesta tese, manifestações musicais que em muitos casos não encaixam nas qualidades rítmicas e na instrumentação que mais 
se relacionam ao campo do rock no mundo, menos ainda ao rock'n roll como seu núcleo "primeiro". E não entanto, dificilmente um ouvinte de música argentina da época duvidaria em inclui-las no "rock nacional". Assim, o autor expressava essa não coincidência:

la particular estética del género -íntimamente ligada a un determinado tipo de relación social- determina que el movimiento de rock nacional, sin ser estrictamente rock en lo musical, aunque sí lo es en lo ideológico, no puede adscribir a otra cosa que a la música argentina contemporánea (VILA, 1987, p 24).

Em um trabalho da nossa autoria, no qual tentávamos apresentar o "rock argentino" referindo-nos à sua extensão até final do século XX, tentávamos dar uma ideia dessa heterogeneidade com uma síntese que, de modo geral, ainda nos parece adequada:

Não se compreende, na Argentina, por "rock nacional", um determinado ritmo ou modo de composição, senão uma identificação com modos de produção e circulação, com âmbitos de execução da música, com posturas ideológicas de outras expressões "rock" no mundo, com a estética dessas expressões, com linhagens em relação a antecessores. Do ponto de vista da materialidade sonora, o que cai sob a denominação "rock nacional" é extremamente heterogêneo, incluindo rock, balada, folk de cunho estadunidense, blues, fusões com folclore argentino, com jazz, com tango, com diversas formas de canção popular anterior (rancheira, valsinha), com ritmos caribenhos, uruguaios, brasileiros, com aproximações da música erudita via a influência do rock sinfônico inglês dos 70, e outras expressões. (FANJUL, 2008, p 125)

Devemos a Claudio Díaz (2005) a que consideramos a cartegorização que melhor ajuda a delimitar o rock argentino como fenômeno, e que é a que aqui adotaremos. Díaz o caracteriza como um campo ou subcampo na produção de bens simbólicos. Seguindo a inserção dessa categoria na teorização de Bourdieu, que mencionamos no Capítulo I, item 4.2., Díaz vai percorrendo as primeiras épocas do "rock argentino" e mostrando como vão se dando nele os traços que caracterizam a constituição de um campo: critérios iniciais de delimitação que se reformulam num conflito recorrente, luta pela legitimidade de enunciar no campo, locais de reunião e exibição identificados com essa corrente, instituições de referência, como revistas e crítica especializada, capital simbólico crescente dos músicos pioneiros e, sobretudo, denominações que começam a diferenciá- 
los nitidamente de outras expressões musicais: primeiro "música progresiva"13, "nueva música urbana" e a que finalmente subsistiu, "rock nacional", alternando com "rock argentino".

O trabalho de Díaz permite caracterizar essa "música progressiva", como uma das principais formas que ganhou, na Argentina, a renovação que se produz no mundo, na década de 60, na música de tradição popular, e como uma das formas da contestação cultural que se dava no país. Uma procura da experimentação, da elaboração na composição musical e nas letras que, com maior ou menos sucesso, tentavam sair dos esquemas da "música para jovens", que, paralelamente, começa a ser denominada como "convencional". O fato de que, posteriormente, o fenômeno inovador tenha ficado aderido ao nome "rock" com uma especificação nacional permite comparar o processo com outros países onde a sorte da denominação "rock", na mesma época, foi muito diferente.

Não é um objetivo desta tese a comparação com a produção brasileira, como fizemos em outros trabalhos (FANJUL 2010, 2013a e 2015), mas cremos que um brevíssimo contraponto possa ajudar a ilustrar, para o leitor brasileiro, o alcance do que tentamos descrever. No Brasil, as transformações culturais da década de 60 também darão lugar a procuras inovadoras dentro da música de tradição popular, mas a partir de um processo muito diferente do argentino, que dará lugar a outro tipo de recepção daquilo que chega do mundo como "rock". Napolitano (2014, p 208-209) explica que a denominada Música Popular Brasileira (doravante, MPB), que o autor considera mais como uma "instituição sociocultural" do que como um gênero, será o âmbito principal de desenvolvimento de inovações. O que na Bossa Nova começa sendo uma perspectiva "hedonista contemplativa" (ibidem, p 208) vai dando base a uma forma musical renovadora que se apresenta também como "politicamente engajada" em torno da qual se consolidará a denominação "MPB".

No mesmo período, o nome "rock" vai ficando progressivamente ligado a uma produção direta da indústria cultural, cuja expressão mais destacada é a chamada "Jovem Guarda", precisamente o tipo de música "para jovens" convencional e conformista do qual, na Argentina, se afastava o setor que acabou portando a denominação de "rock".

\footnotetext{
${ }^{13}$ Essa denominação já circulava para algumas vertentes do rock no mundo. Para Fischerman (2013, p 145), trata-se de uma denominação "adorniana", provavelmente em referência à caracterização de Adorno ([1930] p 148) sobre a "coerência imanente", atingível pela relação dialética entre o material e a liberdade do compositor, que constituiria o "progresso" em música. O emprego efetivo do termo dentro do campo do rock esteve relacionado, de modo geral, à complexidade como valor, que explicamos no item 2.
} 
Existem, no Brasil de finais dos 60 e começos dos 70 outros empregos do termo para realizações musicais com procuras estéticas mais complexas e questionadoras, como Raul Seixas ou Mutantes, mas que não chegam a consolidar um espaço definido.

Precisamente Os Mutantes, banda que já em 1968 incursionava no experimental tanto quanto os pioneiros do rock argentino, fará parte da experiência da Tropicália, fenômeno que explica por que, no Brasil, as modalidades roqueiras são absorvidas pelo diversificado campo da MPB. O tropicalismo inspirado por Caetano Veloso, Gilberto Gil, Tom Zé e outros artistas fusionará elementos de diversas procedências da tradição musical brasileira com outros provindos de diversas expressões de vanguarda, incluindo alguns desenvolvimentos do rock no mundo (FAVARETTO, 1995). A Tropicália, embora seu desenvolvimento e os nomes que a impulsionaram não possam ser separados da MPB, é, muito mais do que outros setores desse grande campo, próxima de valores contraculturais em auge nos 60 , tais como a liberação sexual, a experimentação psicodélica ou formas de vida comunitária, valores e práticas que a aproximam do espaço do rock no mundo. Para Polimeni (2001) essa combinação de fatores é decisiva para entender a não consolidação de um campo específico do rock brasileiro nas décadas de 60 e 70 :

Es que los bahianos filtraban lo que por el mundo había -llegaron a hacerlo años después también con el reggae- y lo adaptaban a coordenadas propias, de tal manera que introducían al público, a modo de visita guiada, en géneros que, por ende, perdían la posibilidad de trabajar en esa cultura un lugar propio. [...] Entre el Tropicalismo, su primo, el llamado MPB, y las decisiones de la industria, que creía que era más fácil importar que trabajar para descubrir lo que hubiese que descubrir, el camino para un hipotético rock brasileño de masas fue cerrándose, hasta terminar en un desfiladero. (POLIMENI, 2001, p 139).

Só na década de 1980 aparecerá com força, em algumas das grandes cidades brasileiras, um setor identificado inequivocamente com o "rock", que chega a constituir em torno de si um espaço com caraterísticas de um campo: lugares de apresentação específicos como o "Circo Voador" no Rio de Janeiro, crítica especializada, instâncias de reconhecimento e uma denominação que vai se consolidando como "BRock" (DAPIEVE, 1995; SEVERIANO, 2008).

Voltando à Argentina dos 60, Díaz (2005) evidencia que houve um período em que a diferenciação nítida do "progressivo" em relação à música promovida pela indústria 
cultural ainda não era evidente mais que para uns poucos músicos, e que, por isso, em várias ocasiões houve espetáculos que misturavam "progressivos" e "convencionais". O trabalho jornalístico de Ábalos (2009) permite também perceber essa instância. Trata-se de um aspecto obliterado no relato de origem que o campo foi construindo sobre si mesmo, mediante sua historiografia e crítica especializada, à medida que foi consolidando-se e ganhando prestígio, relato que em muitos casos confere aos pioneiros uma aura de heroísmo desinteressado e isolamento total.

Não obstante, os dados sobre discos publicados mostram que, indiscutivelmente, foi muito árduo, para os pioneiros do que seria o "rock argentino", chegar a gravar. Entre 1967 e 1968 apenas aparecem alguns compactos e um único LP (o primeiro da banda Los Gatos, cujos principais referentes contavam com alguma trajetória anterior em música mais convencional). Em 1969 é criado o primeiro selo gravador independente, Mandioca, promovido pelo editor Jorge Álvarez. Esse intelectual tinha criado, no início da década, uma editora de livros que seria uma das que veicularia parte da produção da "Nueva Izquierda", a primeira a publicar autores como Manuel Puig e Ricardo Piglia e localizada no bojo da renovação cultural dos 60 . A gravadora teve curta vida, mas um papel muito importante ao possibilitar a publicação de alguns LPs e compilados, e teve uma certa continuidade, a partir de 1971 e já com o campo mais consolidado, com o nome de Talent, como subempresa menor da Microfon.

Em alguns capítulos desta tese, sobretudo os VIII e X, apresentaremos dados que mostram um crescimento relativamente constante, durante os primeiros anos da década de 1970, daquilo que começou como um conjunto de experiências de alcance e público muito restrito. Porém, em nenhum dos períodos que abrange esta tese o rock argentino atingiu real repercussão de massa. Isso só chegaria no início dos 80 , com o final da ditadura, em parte devido a esse caráter agregador de uma resistência juvenil difusa que, como vimos a partir de Vila (1985), adquiriram seus recitais, em parte pelo impacto da Guerra das Malvinas na programação radiofônica ${ }^{14}$. É com esse caráter massivo que chegará uma valorização retroativa e uma construção da "história" do campo pelo jornalismo especializado. A multiplicação acontecida a partir dos 80 significou também uma grande diversificação do campo, tanto na música quanto na dimensão verbal. Foram

\footnotetext{
${ }^{14}$ Durante os três meses de conflito bélico em 1982 a maioria das rádios suspendeu a música em inglês, o que obrigou a ocupar a programação com música em espanhol. Mesmo terminada a guerra, um certo impulso à escuta de música nacional continuou, e o rock argentino se favoreceu grandemente por esse motivo.
} 
incorporadas novas derivações do campo do rock no mundo, como o metal, o ska, o glam, o grunge ou o rap, e aumentou consideravelmente a fusão com gêneros do folclore argentino e com o tango. Na massificação operada nas décadas de 80 e 90, o rock nacional também se diversifica socialmente, estendendo-se, tanto em músicos como em público, aos setores crescentemente pauperizados, acompanhando o aumento da pobreza no país (SEMÁN e VILA, 2001).

Não é um propósito desta tese discutir se ainda pode se postular, hoje, a permanência de um campo do rock argentino. Não obstante, nada impede que informemos, neste ponto, que tendemos a concordar com críticos e músicos como Dacal ([2006] 2008) e Graziano (2011), que consideram seu esgotamento no final dos 90 ou começos dos 2000. Alguns dos fatores considerados são a imensa diversificação estilística, o modo como a produção é afetada pela existência de modos de circulação e reprodução completamente novos, e, sobretudo, que o potencial dissidente, hoje, se percebe mais em fusões e derivações que não se reconhecem sob esse nome.

Encerramos este item com esclarecimentos sobre as denominações que empregaremos nesta tese. Como já explicamos, "rock argentino" é um nome que se consolida depois do período que será nosso objeto, mas que hoje se refere também a esse período. Mostramos já que houve outras denominações, como "música progressiva", e as citações de autores argentinos que já apareceram no capítulo deixam ver que, dentro do país, circula também o nome "rock nacional". Adotaremos aqui "rock argentino", muitas vezes como "primeiro rock argentino", ou "rock argentino nascente", ou "incipiente" e outras determinações. Como teremos que nomear o fenômeno muitas vezes, para não redundar em um mesmo parágrafo, empregaremos por vezes "música progressiva" ou "progressivo argentino", esclarecendo desde já que tentamos nos referir ao mesmo campo.

\section{O primeiro rock argentino e o confronto ideológico e discursivo}

Como localizar, no panorama político e cultural que traçamos no item 1 , os jovens músicos que vêm constituir esse novo subcampo que vai adquirindo o nome de "rock argentino", bem como seu público, sua crítica, seu discurso? Cabe perguntar-se primeiro: é acaso pertinente procurar esse tipo de relação, quando não se trata de agentes do campo 
intelectual ou acadêmico, nem de práticas artísticas previamente prestigiosas? Cremos categoricamente que sim, por duas ordens de motivos. Por um lado, porque em uma formação social com uma desigualdade relativamente baixa e altas taxas de escolarização como a que descrevemos, a circulação de leituras, sobretudo nos espaços urbanos, era profusa e, como descrevem os autores que veremos nesta seção, despertava o interesse de amplos setores. Por outro lado, porque cremos que, na construção de relatos históricos sobre o rock argentino há um certo exagero em torno do seu suposto isolamento inicial em relação ao resto do campo da produção de bens simbólicos. Abordaremos esses dois aspectos a seguir.

De modo geral, os estudiosos e críticos que tratam da época apontam um amplo alcance do influxo inovador para muito além do campo intelectual, e um impacto mais ou menos difuso, mediante vinculações discursivas menos "conscientes de si", sobre todo tipo de práticas culturais. Terán (2008, p 277), afirma que "los afanes modernizadores en la cultura contaban asimismo con una estela de difusión que desbordaba los círculos académicos". Ainda sobre o alcance das novas ideias e sensibilidades para fora do campo intelectual, vale a pena nos determos nesta outra consideração do autor:

Comprobamos así que, en el período 1956-1976, en el sector intelectual -aunque con extensiones que van más allá hasta abarcar zonas considerables de las clases medias y hasta fracciones populares- se sucedieron y cohabitaron estructuras de sentimiento análogas a las que recorrían el arco occidental. Estas fueron desde las sensaciones de angustia, soledad e incomunicación hasta las de confianza en que la voluntad tecnocrática o política podía modificar, por vía reformista o revolucionaria, realidades tradicionales. (TERÁN, 2008, p 275-276, grifo nosso)

Também Pujol (2007a, p 285-286) apresenta consumos culturais de prestígio como muito expandidos entre os jovens, embora a quantificação "milhões" possa ser um tanto hiperbólica:

millones de argentinos mayores de 15 y menores de 40 -acaso tan lejos de Palito Ortega como del hipismo- leían a Rodolofo Walsh, pero también a Julio Cortázar, Jorge Luis Borges, Manuel Puig, Leopoldo Marechal, Haroldo Conti, Marta Lynch y Bernardo Kordon, escuchaban mucha música -del folklore al jazz, de Los Beatles a Pescado Rabioso-, veían cine con fruición y sabían quién era Antonio Berni y por qué se hablaba tanto de Marta Minujin. 
Algumas reflexões de Sarlo (2007) sobre fontes para uma memória das décadas de 1960 e 1970 na Argentina também nos parecem pertinentes para fundamentar por que cremos que configurações de pensamento sobre o homem e a sociedade, em discussão no campo intelectual, chegavam -não isentas de vulgarização, é claro- a setores sociais urbanos e escolarizados muito mais amplos. Sarlo se refere, nesse ensaio, às polêmicas políticas, chamando primeiramente a atenção para algo com que todo aquele que pesquise a época pode se deparar: mesmo nos meios jornalísticos da indústria cultural, essas discussões impregnavam as notícias e reportagens não apenas da seção "política", mas praticamente todas. Além disso, para o que a ensaísta denomina como "imaginário da revolução" (2007, p 63) na militância de esquerda, existiam versões simplificadas "para usos práticos" da teoria marxista que iam muito além do espaço universitário, e que se fundamentavam em qualquer caso, em fontes textuais consideradas de leitura necessária, acontecesse ou não essa leitura. Esse caráter fortemente letrado da circulação de ideias "sob formas discursivas textuais, livrescas" (p 65) atingia muito mais que a militância política e que os espaços universitários. Sarlo traz à tona coleções de fascículos publicados pelo Centro Editor da América Latina sobre temáticas históricas e culturais que se vendiam nas bancas de jornal "às dezenas de milhares" formando "uma biblioteca popular que podia ser encontrada em toda a Argentina" (p 126). Embora Sarlo focalize especificamente as temáticas da luta de classe e dos projetos revolucionários em política, nada impede prever que as mesmas condições de circulação favorecessem uma propagação analogamente difusa de interrogações sobre a cultura, a arte, e criação e as relações humanas que, no fim das contas, faziam parte de um mesmo processo de renovação e de questionamento.

Portanto, cremos que podem ser indagadas e hipotetizadas relações entre a discursividade no rock argentino e a de diferentes vertentes desse pensamento que Terán caracteriza como "humanocêntrico", que marcou a vida intelectual e cultural argentina e sobre o qual voltaremos com mais detalhe no Capítulo IV. É claro que essa indagação deve considerar as diversas mediações, já que não se tratava sequer de estudantes universitários, mas de músicos e poetas muito jovens.

Qual era a localização desses músicos em relação ao campo cultural? Com certeza não eram próximos das práticas de mais prestígio no que Bourdieu ((1976] 2003) denomina "degustação ilustrada" e que organiza a hierarquia das obras no campo cultural. Mas também não eram alheios ao que acontecia nesse campo, nem se fizeram sozinhos na cultura argentina, como pretendem algumas versões do relato jornalístico e biográfico. 
A leitura de estudos como o de Grinberg (2008) mostra que muitos deles tinham contato com as vanguardas artísticas, de modo geral compostas por gente menos jovem. Todos os membros do trio Manal, por exemplo, frequentavam o Instituto Di Tella, inclusive Claudio Gabis e Javier Martínez, guitarrista e baterista do trio, conheceram-se ali, em uma das jornadas abertas que ali se faziam para que, quem quisesse, tocasse algum instrumento. A banda Almendra debutou no Di Tella. As leituras que alguns deles declaravam, como levanta Díaz (2005), incluíam alguns dos escritores canônicos na época, como Cortázar ou Marechal, e inclusive alguns diziam ter lido Camus e Sartre (CARNICER, 2015). Em alguns dos jovens roqueiros (Moris, Pipo Lernoud, Javier Martínez), conforme os documentos e entrevistas levantados por Grinberg, era perceptível inicialmente a adesão a um certo anti-intelectualismo, do "fazer em vez de falar" que, no entanto, não deixava de ser uma das posturas existentes, conforme também explica Terán (1991, p 151-162), entre os intelectuais da época.

No item anterior mencionamos outro fato que evidencia o contato dos jovens roqueiros com a renovação que se operava nos campos intelectual e cultural: a criação da gravadora independente Mandioca pelo editor Jorge Álvarez, empreendedor estreitamente relacionado às correntes e grupos que participavam desse amplo processo.

Por sua parte, Jacoby (2011, p 96), lembrando encontros no Bar Moderno, onde confluíam (mesmo que em mesas separadas) a vanguarda artística e os intelectuais de esquerda, descreve a seguinte situação que ilustra não apenas a proximidade, também o tipo de distância que separava os novos músicos desses grupos consolidados. Segundo o sociólogo -na época, artista experimental-, os jovens roqueiros ficavam do lado de fora do bar "no tanto porque fueran menores de edad, como porque no tenían un peso para tomar algo, y además, el sentarse a tocar la guitarra en la vereda significaba un gesto hippie de auténtico rechazo a la sociedad burguesa". Jacoby conta que quando ele e seus colegas convidaram o grupo de fora para entrar no bar, conheceu Miguel Abuelo, Tanguito e Pedro Pujó (dois solistas e um poeta e letrista que foram parte dos pioneiros) “y muchos otros seres mitológicos de la cultura urbana local” (ibidem, p 96).

\section{As indagações e o corpus desta pesquisa}

A escuta e a observação criteriosa das primeiras etapas do rock argentino, como nova escuta para esta pesquisa, se deu já pensando em quais aspectos (objetos de discurso, 
configurações enunciativas, cenografias) podiam ir marcando o traço material de uma regularização que vínhamos percebendo a través de trabalhos nossos anteriores, quase todos eles abrangendo outros períodos juntamente com o primeiro. As leituras mais intensas sobre o debate político e cultural na Argentina dos 60 e 70, bem como as da pesquisa acadêmica e da crítica especializada sobre o rock do país foram nos convencendo de alguns caminhos frutíferos para tentar construir as hipóteses sobre regularização que são objetivo deste trabalho.

Não apenas percebíamos em muitos materiais de e sobre a época desdobramentos discursivos do que Terán, como vimos em 1, expressa como um humanismo materialista em que "o indivíduo é confrontado com seus limites". Também víamos, na dimensão verbal de muitas composições, uma centralidade do indivíduo, uma tematização constante das suas escolhas ou deserções, mesmo tratando do amor, do desejo, do trabalho, da fadiga, da amizade, da natureza, do canto ou da própria música. Em um clima cultural e ideológico que porta a necessidade de mudança e transformação como pré-construído, e que se pergunta pela possibilidade -ou impossibilidade para algumas vertentes, como veremos no Capítulo IV- do homem de agir, fomos pensando em observar como esse primeiro rock argentino tendia a representar o ser em ato, que formas adotava essa focalização do indivíduo e seus deslocamentos.

Nesses movimentos reflexivos, em idas e voltas com a observação e a escuta do repertório, fomos encontrando os focos que principalmente observaríamos nas canções: como se representam os deslocamentos dos seres, os percursos de vida, a formulação de modelos e contramodelos, e a atividade artística ou "criadora". Esses foram os pontos de partida, e sua observação foi impondo o acréscimo de outros: o propósito ou sua falta, o vínculo amoroso, a ação violenta. Também foram aparecendo, no caminho analítico, topografias e cronografias que fomos tipificando e que se articularam com outras regularidades: o amanhecer, a rua, o quarto, o refúgio. Em torno desses objetos fomos encontrando regularidades relativas às instâncias de pessoa e a diversos tipos de enunciador, que articulamos com a percepção de determinados pré-construídos. E por esse caminho fomos construindo a hipótese de uma regularização que teria caracterizado esse primeiro período do "rock argentino", mas que manteve uma repetibilidade durante toda a existência do campo, e também a hipótese de uma desregulação parcial. Ambas, como também as posições de sujeito que consideramos que atravessaram 
contraditoriamente a série, serão apresentadas ao longo desta tese, sobretudo nos capítulos IV, VIII e IX.

Procedemos a uma formação de corpus em dois níveis. Por uma parte, o que poderíamos estabelecer como primeiríssima etapa do progressivo, até a dissolução das três primeiras grandes bandas (Los Gatos, Manal e Almendra) em 1971 foi considerado na sua totalidade. Tudo que a partir de 1966 e até então foi gravado em discos, ou que sabemos que foi composto naquela época, mas foi gravado depois, entrou no corpus, como também algumas poucas músicas que não foram gravadas em discos, mas que apareceram depois como registro de gravações ao vivo. Isso significa que incluímos as seguintes obras dos solistas e bandas que detalhamos:

Solistas:

Moris ( $1^{\circ}$ LP e $1^{\circ}$ compacto)

Miguel Abuelo (os três compactos publicados na época)

Tanguito (único LP gravado)

Luis Alberto Spinetta (músicas solistas gravadas depois, mas compostas na época, e LP solista de 1971)

Bandas:

Los Beatniks (único compacto gravado)

Los Gatos (1 compacto e 4 LPs)

Manal (Os dois LPs em estúdio e os dois compactos gravados antes da separação)

Vox Dei $\left(1^{\circ} \mathrm{LP}\right)$

Almendra (Os dois LPs e os quatro compactos gravados, mais gravações inéditas ao vivo)

La Barra de Chocolate (único LP gravado)

Pappós Blues (1 $\left.{ }^{\circ} \mathrm{LP}\right)$

Então, essa primeira etapa é incluída na sua totalidade, e, dentro dela, depois da (re)escuta integral, decantamos primeiramente as composições em que de algum modo 
aparecem representados os objetos que detalhamos acima, e que de fato são a maioria. Nos capítulos IV, V, VI e VII é que se desenvolve o trabalho sobre esse nível do corpus, que se retomará depois, é claro, em diálogo com o outro. Isso não quer dizer, como se verá nos próximos capítulos, que, nas análises que vamos expor, tratemos de todas essas músicas, ou de todas da mesma maneira, o que daria lugar a um trabalho interminável e repetitivo. A exaustividade é um critério que valida nossa busca, e que a oferece para contestação dentro dos estudos sobre esse campo ou de quem se aproxime dele, permitindo não apenas a apresentação de contra-exemplos, como também que sejam visíveis as bases da nossa construção descritiva e explicativa: por que encontramos mais saliência em determinadas músicas que em outras. Não cremos que a ordem do discurso determine regularidades uniformemente repartidas, antes bem ela nos aparece como condensações desiguais e como ausências. Por outra parte, também não abordamos cada música como totalidade e de uma só vez. Em vários casos, por exemplo, composições sobre as quais tratamos no Capítulo IV são retomadas no VI em função da figuração que nesse capítulo é estudada.

Um segundo nível de corpus é o que corresponde ao que consideramos a desregularização parcial, e que abrange composições de aproximadamente 1970-71 a 1975. Trata-se, ainda, do que se considera o rock argentino "primeiro" ou "clássico", embora inclua o que para alguns estudiosos como Grinberg (2008) ou Colomba (2010) é uma segunda etapa que começaria em 1972 com o crescimento do número de discos gravados. Nós não temos como objeto, neste trabalho, uma divisão em etapas ou períodos. Se organizamos o corpus dessa maneira é devido às observações feitas no plano do discurso. Não pensamos que a regularização que localizamos no primeiro corpus deixe de se manifestar nos anos em que aparecem os acontecimentos que caracterizamos como desregularização parcial, não são "etapas” separadas. É mais, uma não pode existir sem simultaneidade e co-ocorrência com a outra, não há como compatibilizar uma cronologia do relato histórico com esses processos no discurso.

Para esse segundo nível não operamos a partir da exaustividade, trabalhamos com aquilo que nos permite expor por que pensamos que houve uma desregularização parcial. Se nos detivemos em 1975 foi por suas razões. A primeira é que consideramos que, para mostrar uma desregularização parcial, o que há até esse momento é suficiente e têm centralidade em relação ao campo, dados os músicos e bandas que abordamos nos capítulos IX e X. A segunda é que, a partir do golpe de Estado de 1976, condições de 
produção imediatas muito diferentes devem ser consideradas, o que implicaria a continuidade em outro trabalho e com outro critério de conformação de corpus. Como se verá a partir do capítulo VIII, a repressão e o terrorismo de Estado não foram inaugurados pela ditadura civil-militar de 1976, e o rock argentino e seu público foram alvo da violência de Estado desde bem antes. Porém, o golpe muda qualitativamente alguns fatores cruciais na reprodução e circulação, como podemos apreciar em Díaz (2005) e Pujol (2013): inviabilidade de recitais, censura generalizada, saída do país de músicos que começam a compor sob outros determinantes imediatos.

Mesmo assim, podemos afirmar que localizamos e (re)escutamos, para determinar aquilo que traríamos para as análises, praticamente toda a produção entre a separação das grandes bandas e 1975, anos em que a gravação cresceu quantitativamente, e a quantidade de bandas aumentou para além das que foram organizadas por aqueles que saíram das primeiras. Isto é, a diferença entre ambos os níveis de corpus quanto a exaustividade na indagação foi mínima. Então, o material que abordamos nos capítulos IX e X foi extraído de um panorama que incluía os seguintes solistas e grupos:

Solistas:

Moris $\left(2^{\circ} \mathrm{LP}\right)$

León Gieco (os 2 primeiros LPs)

Lito Nebbia (solista, depois da separação de Los Gatos, 3 LPs)

Raúl Porchetto (1 LP)

Bandas:

Sacramento (único LP gravado)

Vox Dei (3 LPs)

Pedro y Pablo (2 LPs)

Pescado Rabioso (2 LPs)

Pappo’s Blues (2 LPs)

Arco Iris (2 LPs) 
La Cofradía de la Flor Solar (único LP gravado)

Aquelarre (3 LPs e um compacto)

Diversas formações de La Pesada del Rock’n Roll (4 LPs)

El Reloj (1 LP)

Vivência (2 LPs)

Pastoral (2 primeiros LPs)

Espíritu (1 LP)

Sui Generis (3 LPs e gravações ao vivo)

Porsuigieco (único LP gravado)

\section{Estabelecimento de letras e outros esclarecimentos sobre fontes}

Todas as letras que constam nos apêndices foram estabelecidas por nós com a escuta da versão correspondente à gravação considerada, que se especifica no corpo da tese ao mencionar a música correspondente. Para esse estabelecimento das letras, cotejamos nossa escuta com os encartes ou com transcrições em sites oficiais dos músicos, com transcrições feitas por críticos e/ou jornalistas e biógrafos em material publicado, e em alguns casos, com consultas a outros estudiosos. $\mathrm{Na}$ dúvida, preferimos a opinião de outros estudiosos e a nossa escuta antes que os encartes e transcrições em outros meios.

Todas as fontes jornalísticas empregadas estão especificadas com os procedimentos habituais de referência em trabalhos acadêmicos, inclusive as da mídia online. Mesmo assim, queremos tratar brevemente aqui sobre uma fonte jornalista específica, que citamos pouco, mas que empregamos para conferir dados como ano de gravação das músicas, autorias em casos duvidosos e companhias gravadoras, quando nos pareceu relevante. Trata-se de Rock.com.ar, empreendimento jornalístico privado ligado à revista Dale, e no qual têm trabalhado vários dos mais conhecidos críticos e jornalistas especializados. É considerado um centro de referência muito confiável. No caso do único documento exclusivo do site que empregamos, os desenhos de Luis Alberto Spinetta 
publicados em 1970 na revista Alquitrán ${ }^{15}$, consultamos também diretamente o jornalista Víctor Pintos, que foi quem encontrou os desenhos e os subiu na época em que ele coordenava o site.

\section{O caderno de Anexos}

A pasta de Apêndices que acompanha esta tese contém um CD com as gravações das 95 músicas abordadas, e a transcrição de suas letras. Preferimos não colocar no corpo da tese, salvo em casos excepcionais, toda a letra no momento de referência a uma canção, já que para muitas delas há referências em partes diferentes do trabalho, e também para facilitar uma leitura conjunta e evitar que o leitor deva voltar constantemente páginas atrás. A localização em pasta aparte permite, assim, uma leitura continua do texto da tese, com a letra aparte para ser consultada quando o leitor o considera necessário, ou enquanto escuta a gravação correspondente.

Em todos os casos a gravação é a primeira editada em estúdio, salvo nas ocasiões em que se indica algo diferente no corpo da tese. Quando, em função da argumentação que desenvolvemos, oferecemos mais de uma versão, como nos casos de "Las Guerras", de Vox Dei (Capítulo IX), e "Instituciones", de Sui Generis (Capítulo X), a diferenciação está especificada tanto no CD quanto na transcrição.

Consideramos que a ordem alfabética pelo nome de cada composição é o modo mais prático de ordenamento. A ordem cronológica teria sido inviável, já que para algumas músicas o ano de composição é incerto, e mesmo dentro de cada ano seria necessário outro critério de sequência. Ordenar por compositor ou por banda teria requerido do leitor um conhecimento muito aguçado do campo, já que muitos autores foram solistas e também membros ou líderes de bandas e há, além disso, algumas composições em parcerias. Os dados de gravação e execução de cada música estão no corpo da tese quando ela é apresentada e/ou retomada, mas no anexo também constam as autorias, e a diferenciação entre bandas e solistas.

\footnotetext{
${ }^{15}$ No Capítulo V haverá referência a esses desenhos.
} 


\section{Entrando nos percursos}

Os dois primeiros capítulos foram os prolegômenos necessários para explicitar a identidade teórica, metodológica e de objetos da nossa pesquisa. A partir do próximo capítulo, já passamos ao próprio desenvolvimento do trabalho, como percursos reflexivos a partir da materialidade verbal e sonora do campo estudado. Começando, como já anunciado, pelas exterioridades, pelo modo de estar daquilo que não está. 


\section{Capítulo III}

\section{Morte sem mortes; estados de amor}

\section{(Indiferença)}

Durante uma estadia na Argentina, em 2009, precisamente para ministrar, na Universidad de Buenos Aires, um curso de pós-graduação sobre o discurso no rock desse país, veio-nos, no final do dia, uma interrogação motivada pela discussão com os alunos durante a aula. Vários deles tinham chamado a atenção sobre a abundante referência à morte em letras de determinada época. No momento, tínhamos concordado, mas algo não fechava. E aí nos perguntamos: acaso alguém morre no rock argentino? Por que entre tanta morte não lembramos de algum morto?

Nossa própria pergunta nos surpreendeu e começamos a indagá-la. O que não vinha à nossa memória era alguma morte individual, de uma personagem (ou dessas quase personagens que ganham contornos nas canções, com pinceladas de biografia). Algo com causa mortis: doença, acidente, crime passional, fome, tristeza, assassinato político, execução, morte em guerra (de alguém em especial, não de exércitos e populações). Alguma morte narrada. Ou a evocação saudosa de algum morto específico. Suicídios, muito poucos, e só aparecem om o campo já muito desenvolvido ${ }^{16}$.

No dia seguinte dividimos a inquietação com os alunos do curso, de modo geral conhecedores do repertório, e entre todos fomos lembrando de alguns poucos casos. E cada um que lembrávamos nos trazia um questionamento. Em "Mariel y el capitán”, de Charly García, o casal romântico morria (ela era assassinada pelos vizinhos e ele se suicidava), mas todos a considerávamos uma música humorística, não "séria". Menos séria ainda era a debochada matança familiar em "Mr. Jones", no mesmo disco de Sui Generis ${ }^{17}$. Diferentemente, "Natalio Ruiz”, personagem de uma música da mesma banda,

\footnotetext{
${ }^{16}$ Duas músicas de Charly García em períodos posteriores aos que abrange esta tese narram suicídios: "Iba acabándose el vino", de 1977, e "Viernes 3 AM", gravada com a banda Seru Giran em 1979 e vertida ao português por Herbert Viana para Paralamas do Sucesso. Em um artigo que publicamos alguns anos atrás (FANJUL, 2013a), analisamos comparativamente a versão brasileira e a argentina com foco na delimitação de vozes e entidades pessoais.

${ }^{17}$ A produção dessa banda, primeira em que atuou Charly García, será abordada em outros capítulos.
} 
terminava, sim, no cemitério, sendo o único nome próprio com uma morte "séria" que veio à nossa memória, mas era morte natural. E era só um. Também em La Biblia, de Vox Dei $^{18}$, alguns morriam (Golias, Cristo), mas eram, precisamente, personagens bíblicos, de outra história com morte já narrada. Também "El fantasma de Canterville", de Charly García, vinha de outra história, e além disso, andava vivo depois de morto. Em capítulos posteriores, duas dessas “não-tão-mortes”, em Vox Dei e em Sui Generis, serão abordadas de modos que reverterão algo desse questionamento, mas neste ponto preferimos continuar com o raciocínio mais geral que surgiu naquela ocasião.

Não havia sequer uma canção a Tanguito ${ }^{19}$, morto nas primeiras etapas do movimento, ou a figuras admiradas que morreram naquele tempo, como Hendrix ou Janis Joplin. Nem pelo menos um canto de algum músico a seus familiares, amigos, avós, vizinhos, companheiros que tivessem falecido. Lembramos que Spinetta tinha composto "Tema de Pototo" em uma ocasião em que acreditou que um amigo seu morrera, mas, na música, a suposta morte do amigo é elíptica, não dita na figuração da sua ausência. E ainda a referência é genérica e esacandida pelo tom proverbial que, como veremos, atravessa o rock argentino em diversas épocas: "la soledad es un amigo que no está". Depois daquela ocasião do curso na UBA, uma procura orientada nos depararia outros exemplos, que mencionaremos neste capítulo, mas primeiro delimitaremos com maior precisão a forma que foi ganhando essa lacuna que sentíamos ter detectado.

Propusemo-nos uma problematização do que tinha surgido como uma intuição de seguidores do gênero, para tentar transformá-la em uma pergunta que prefigurasse um percurso crítico. O primeiro que tinha suscitado nossa inquietação era um forte contraste. O rock argentino, sobretudo na década de 70, mas também em alguns dos seus desdobramentos posteriores até o final da década de 80 , está povoado de referências à morte e a mortos de modo genérico. Composições como "La maldita máquina de matar" (Billy Bond y La Pesada), "La muerte contó el dinero" (Alas), "Cruzando la calle" (Aquelarre), "Hombres de hierro" (León Gieco), "Esto se acaba aquí" (Claudio Gabis), "Hoy, recién hoy", "Desde que" (Pastoral), para mencionar alguns, tematizam o morrer e o matar, ou põem em cena atmosferas mortuórias. No repertorio de Sui Generis, uma das bandas mais escutadas da década de 70, que trataremos amplamente no Capítulo X, o

\footnotetext{
${ }^{18}$ LP ao que nos referiremos no Capítulo IX.

${ }^{19}$ Pseudônimo do cantor e compositor José Alberto Iglesias, um dos pioneiros do rock argentino. Morreu em 1972, atropelado por um trem, sob efeito do tratamento químico a que era submetido no hospício de onde fugiu. Neste capítulo e no próximo nos referiremos a várias composições dele.
} 
tópico é extremadamente recorrente. A primeira e talvez mais conhecida música do seu primeiro disco, paradoxalmente denominado Vida, foi "Canción para mi muerte", que aparecia como uma celebração amena do inevitável. O terceiro e último disco, Pequeñas anécdotas sobre las isntituciones, continha músicas como "Tango en segunda" ou "El show de los muertos" nas quais a morte domina a cena. O lúgubre estará marcadamente presente na obra do seu compositor, Charly Garcia, na sua carreira posterior até pelo menos oito anos depois da dissolução da banda. Por outro lado, durante a década de 80 , período que não consideraremos nesta tese, as referências a morrer e matar, bem como à morte resultante da violência social e política são constantes nas bandas das linhas metálica e punk. Na obra da banda Patricio Rey y los Redonditos de Ricota, uma das formações mais originais e de público mais multitudinário dos 80 argentinos, morte, cadáveres e sobreviventes circulam, quase sempre de modo genérico, por letras de uma poeticidade críptica. Esse panorama parecia ter um inquietante avesso na ausência quase total de canções que tematizassem a morte de alguém específico. No rock argentino da década de 90, que temos estudado muito menos do que os períodos que nos ocupam neste trabalho, e sobre o qual, devido à sua grande expansão e diversificação, não temos condições de formular afirmações suficientemente fundamentadas, encontramos, sim, alguns casos, em histórias de degradação social, como "Caroncha", da banda Bersuit Vergarabat. Porém, mesmo nessa época do rock argentino, em que há não poucas referências ao genocídio praticado pela ditadura militar de 1976-1982, um estudo muito exaustivo como o de Blanco e Scaricaciottoli (2014), focalizado no político, não registra qualquer composição que trate de alguma vítima em especial.

Uma pergunta que pode surgir é se a não encenação da morte individual que vemos no rock argentino das primeiras décadas não seria uma característica do campo do rock no mundo, pelo menos no mesmo período. Isso não dispensaria, de qualquer modo, interrogar o assunto na especificidade do país que nos ocupa. Porém, embora não tenhamos como dar uma resposta conclusiva, algumas observações parecem indicar que, em todo caso, o contraste específico que encontramos no rock argentino está longe de ser generalizado. Bob Dylan, que influenciou fortemente a letrística do rock em inglês mais ouvido pelos pioneiros argentinos ${ }^{20}$, e é reconhecido inspirador de vários deles (Moris, Tanguito, Gieco, García), compôs famosas canções em forma de crônica que tematizam

\footnotetext{
${ }^{20}$ Sobre a dimensão modelar de Dylan sobre a letrística roqueira em inglês, sobretudo a partir de sua adoção de instrumentos elétricos, ver Conde (2007, p 33-46)
} 
e narram assassinatos ("Hurricane", "The Lonesome Death of Hatle Caroll”, "The Death of Emmet Till").

Poderia ser aduzido, ainda, que as temáticas que "interessaram" os artistas do campo que deviria em rock argentino seriam tais que não favoreciam, como temáticas, a focalização da morte de alguém. Temos, a respeito, duas objeções. A primeira é que quando se revisa a produção crítica que indagou sistematicamente aspectos temáticos nesse campo da música, como Díaz (2005) ou os trabalhos incluídos em Conde (2007), encontramos temas como a solidão, o amor ou a falta dele, a educação opressora, a incomunicação, que bem poderiam dar lugar, como deram em muitos outros gêneros musicais, à narrativização da morte de uma pessoa. E inclusive os assuntos de focalização mais coletiva que encontramos nesses levantamentos, tais como a paz e a guerra, a vida na cidade ou a repressão, poderiam também ganhar forma numa história individual desse tipo, como aconteceu com o racismo nas músicas de Dylan que acabamos de referir. A segunda objeção é que determinadas temáticas e determinados objetos de discurso não emergem em um campo do nada, trazidos pelo mero interesse dos autores a um espaço inicial que seria uma tábula rasa, disposta a receber suas inquietações. Existe uma relação com materialidades discursivas prévias, como existem processos de delimitação e exclusão de temas e objetos cuja força está precisamente na sua aparente naturalidade. Então, quando um objeto tão rodeado e "flertado" como é a morte na discursividade do rock nacional parece teimar em não aparecer sob determinadas formas, em não associarse a determinadas possiblidades de representação do humano, cremos que cabe interrogar aquilo que pareceria obviedade. Suspeitamos da força de evidência com que surge, para nós como para tantos conhecedores e "curtidores" do campo, facilmente tomáveis pelo seu funcionamento imaginário, uma resposta como "é claro que assuntos como esses não teriam interessado o rock argentino".

A percepção dessa ausência e sua confrontação posterior com um corpus construído com certa sistematicidade foi como a ponta de um fio que nos fez "puxar" outras faltas, que poderiam ter sido o fio inicial, já que nenhuma delas conduz para um centro que revelaria alguma essência oculta, mas para relações diversas de exclusão / inclusão. Trataremos sobre essas ausências aqui e no Capítulo VIII, e primeiramente recorreremos de um modo translatício a reflexões de Foucault (1969) sobre a função enunciativa e os domínios de enunciados. 


\section{Carência e bordas}

Denominamos "translatício" esse recurso à proposta foucaultiana devido, em primeiro lugar, à cautela que nos merece o fato de aquela ter sido pensada como projeto para dar conta da construção histórica dos saberes e das ideias disciplinares. Uma "arqueologia do saber" que, embora tenha se apoiado em uma reflexão sobre o discurso em geral como prática humana, não conseguiríamos transferir para campos discursivos da mídia ou da cultura de massa sem um forte estranhamento respeito dos referenciais (termo que aqui empregamos precisamente com o valor que lhe vemos na Arqueologia...) a partir dos quais ela formou seus objetos. Em consequência, mais do que a aplicação de um programa, interessa-nos o resgate de um princípio para a ponderação de um conjunto de regularidades. Em segundo lugar, nossa cautela se justifica porque essas regularidades são percebidas e delimitadas, como vimos já prevendo do Capítulo I, muito mais por procedimentos inspirados em correntes de análise do discurso que em alguns momentos dialogaram com Foucault, do que por aquilo que se esboça na sua obra.

Realizando uma ponderação sobre as modalidades do "não dito", para fundamentar que a análise dos enunciados não pode ter como propósito desvendar algo que ficou "oculto" ou "reprimido", Foucault (1969, p 145) menciona uma ordem de exclusões de outro nível que denomina em francês como "un manque". O termo aparece na tradução brasileira como "uma ausência" (p 125) e na tradução ao espanhol como "una carencia" (p145), denominação que preferimos adotar porque, também em português, “carência" pode dar conta não apenas da falta, mas da sua percepção como a de alguma coisa que poderia estar e cuja não presença tem consequências, valor que nos parece envolvido em "manque" e no verbo francês "manquer". A "carência" seria característica de toda regularidade enunciativa. Em relação ao que Foucualt chamou um campo ou domínio de coexistência de enunciados, dado por regularidades, a carência seria exterior e correlativa, cumprindo um papel na própria existência do domínio. A descrição da carência permite situá-la em relação a outros pontos da reflexão de Foucualt sobre o discurso:

Il peut en effet y avoir - et il y a sans doute toujours, dans les conditions d' émergence des énnoncés, des exclusions, des limites ou des lacunes qui découpent leur référentiel, valident une seule série de modalités, cernent et referment des grupes de coexistence, 
empêchent certaines formes d'utilisation. Mais il ne faut pas confondre, ni dans son statut ni dans son effet, le manque caractéristique d'une régularité énnonciative et les significations celées dans ce qui s'y trouve formulé. (FOUCAULT, 1969, p 145).

Cremos que o tipo de falta que nos inquietou não tem a ver com significações ocultas nem com formas de censura, por isso pensamos que pode ser uma janela para a exterioridade dada pelo recorte que implica todo discurso. Pode haver existido censura ou autocensura em relação a alguns possíveis relatos, por exemplo, nos anos 70, inclusive antes da ditadura, sobre algum assassinato relacionado à luta política. Mas é claro que a abrangência do que aqui estamos expondo como não narração ou tematização da morte individual é muito mais ampla e inclui as muitas possibilidades que mencionamos do início deste capítulo. Também não há expressões dos artistas ou do público sobre que "não se deva" ou "não se mereça" cantar sobre esses temas, como houve, sim, reiteradas menções ao propósito de não cantar na linha do que a indústria cultural promovia como "música para jovens", como vimos no capítulo anterior.

Pensamos que o que aqui tentamos identificar como "carência" tem a ver precisamente com discursos que se ignoram mutuamente e de algum modo se excluem, uma relação que nos aproxima do princípio de "descontinuidade" que o mesmo Foucault enuncia em A ordem do discurso ([1970] 2008, p 52-53), e que dá lugar à possibilidade de pensar séries discursivas. Os princípios que o pensador enuncia nessa parte da sua conferência, dedicada às "exigências de método", dão a possibilidade de pensar as regularidades discursivas como constituídas a partir do corte sempre envolvido no estabelecimento de um referencial, da violência sobre as coisas que implica enunciar, à qual já nos referimos no Capítulo I, da exterioridade como condição de possibilidade do discurso, já que essa exterioridade é precisamente a fixação dos limites da série, que não é realizada pelo projeto de uma consciência. Em A arqueologia..., esses princípios aparecem em torno das propostas para análise dos enunciados e das formações discursivas. Ao tratar da "raridade", a formação discursiva é caracterizada como "uma repartição de lacunas, de vazios, de ausências, de limites, de recortes”, e como pergunta fundamental da descrição dos enunciados formula a de como eles se localizam nas suas relações no sistema lacunar das formações (FOUCAULT, 1969, p 156-157). Por sua vez, a exterioridade é "paradoxal" por não remeter "a nenhuma forma adversa de interioridade" (ibid, p 159). Com efeito, a presença, em outras séries, dos objetos de discurso que, no caso da regularização discursiva dominante no primeiro rock argentino, 
vemos aqui como "carências" não é, de maneira nenhuma, antitética ou oposta ao que se encontra no interior dos enunciados que manifestam essas regularidades. Elas apenas participam da marcação de alguns dos seus limites, proposta que tentaremos mostrar, neste capítulo e no VIII, indo primeiramente à efetiva aparição desses objetos e temáticas, sua não carência, precisamente em composições que foram "ficando fora" desse espaço de regularização, marcando o limite do dizível dentro dele, às vezes com alguma contrapartida distorcida na percepção do que depois foi o "rock argentino" não como campo enunciativo, que não é, mas como agrupamento do discurso irregularmente recortado pelas práticas discursivas que o denominam.

Iremos percorrendo esses casos, poderíamos dizer, limítrofes, como traços de cortes relacionados ora com as transformações que se foram dando no próprio campo de práticas sociais da música de tradição popular em que as práticas específicas que analisamos se desenvolveram, ora nas temáticas e objetos que as vinculam com outras práticas discursivas artísticas e não artísticas. Pensamos que esses vínculos formam parte das condições de aparição dos enunciados, da materialidade significante da qual a enunciação se vale, embora isso possa resultar um distanciamento em relação à perspectiva de Foucault. O que essa observação pode iluminar, do nosso ponto de vista, não é tal ou qual leitura de cada enunciado, mas a delimitação do exterior que foi dando lugar à regularidade que os relaciona. A interrogação dessas bordas irá mostrando relações que dizem respeito à condensação de acontecimentos discursivos que determina essa primeira regularização.

\section{Coisas a evitar}

Vamos começar por algo que se grava em 1973, quando o rock argentino já é um campo -ou subcampo da produção de bens culturais, conforme explicado no Capítulo IIrecente e ainda sem denominações totalmente fixadas, mas já consolidado, para depois retroagirmos ao que hoje aparece como sua pré-história. No início de "Cementerio Club", de Luis Alberto Spinetta, escutamos "Justo que pensaba en vos, nena, caí muerto". 
Deixaremos de lado agora o conjunto do disco $\operatorname{Artaud}^{21}$, no qual essa música apareceu como a segunda na ordem do LP, para pensar na cena de canto e de escuta dessa música em especial.

A vocalização por Spintetta dessa abertura é um cantar próximo da fala, a voz parece interpelar alguém numa conversação cara a cara. As pausas fragmentam o canto desta maneira:

Justo que pensaba en vos / nena / caí muerto

A voz instala uma determinada figura como lugar de incorporação para quem escute e/ou cante junto. E ao dizer "nena", termo consolidado no campo para que a voz masculina (praticamente a única naquela época do rock argentino) denomine uma mulher como objeto de sedução, amor ou desejo, essa figura se estabelece como corpo masculino perante o par feminino. As pausas e o tom da voz dão a esse corpo um movimento oscilante, de leve avanço e leve retração, que não é a abordagem frontal da solicitação ou do toque. A cadência de blues contribui para essa oscilação, o lento ponteio da guitarra elétrica que começa logo nesse ponto propõe como contraparte, para o corpo da escuta, um balançar. As pausas que mostramos em cima isolam o vocativo: "nena", precedido pela forma de tratamento "vos", ainda muito infrequente no rock argentino da época, e que, dentro da divisão do linguístico no país ${ }^{22}$, reforça a possiblidade de presença imediata que estamos descrevendo.

Depois da pausa de "nena", a cadência parece afetar mais diretamente o canto, e vocalização alonga e abre a última tônica em "ca-1́-mueeeer-to". A oscilação com que o canto vinha criando distância ganha um efeito lúdico. de gesto levemente artificioso. A mesma entoação há depois para "que-no-de-teeees-tes". O paralelismo resultante deixa, nos segmentos introdutórios, um ida e volta de percepção entre os membros do par

\footnotetext{
${ }^{21}$ Esse LP é um dos mais discutidos pela crítica do rock argentino e também um dos mais comentados por estudiosos. Apesar de seu nome e de incluir um retrato de Antonin Artaud em um canto do encarte, não musicava a obra poética do surrealista francês, coisa que o próprio músico declara (BERTI, 2014, p 88-93). ${ }^{22}$ Não é um objetivo deste trabalho abordar a problemática, sem dúvida fascinante, das formas de tratamento e de outras manifestações de heterogeneidade linguística que, no rock argentino, atualizam problemáticas ligadas à identidade nacional. É claro que, ao desenvolver uma análise discursiva, tratamos da heterogeneidade linguística, mas em relação aos objetivos que traçamos, que em diversos pontos deste trabalho (por exemplo, no Capítulo VII sobre um LP de Moris) vão nos conduzir para outros gêneros da música popular ou para aspectos da desigualdade social. A questão das formas de tratamento e de outros itens que na Argentina são vistos como marcas de uma pertinência nacional tem sido objeto de escrita em torno do rock, muitas vezes a partir de lugares do senso comum sobre a língua espanhola. Porém, encontramos reflexões a partir de critérios nítidos e articulados em Toscano e Warley (2003).
} 
justo que pensaba en vos ～/ caí muerto

dónde ves ahora algo en mí / que no detestes

Há um distanciamento, algo que perturbou o amor, mas isso não é o centro do cantar, que parece desenvolver-se muito mais sobre o processo de um dos parceiros. "Cair morto" também não é devido ao pensar no outro, aparece como uma concomitância: "justo en esse momento" 23 .

Tentamos mostrar que, nesta música que aflora em um dos períodos em que, como veremos nos capítulos IX e $\mathrm{X}$, abundam as referências inespecíficas à morte e aos mortos, bem como as cenografias lobregas, a irrupção de uma morte individual aparece distanciada de determinadas dimensões patéticas. Não se trata do hiperbólico morrer de amor ou preferir estar morto a estar longe do outro, embora não deixe de roçar, de algum modo, entre lúdico e desdenhoso, esses lugares. Tópicos inseridos na memória da canção de tradição popular, muito menos longe do que o imaginário do rock argentino sobre si mesmo, aquele que opera sobre a já mencionada "certeza" de que ele não se interessa por determinadas coisas, permite perceber. Com efeito, não é habitual que se trate das complexas relações de proximidade e distanciamento entre o rock argentino e o melodramático. Dos estudos publicados até agora, somente o de Colomba (2010) examinou alguns aspectos dessas relações.

Cremos que aquilo que se fez visível, para nós, em primeiro lugar como percepção de carência em relação à morte individual se abre a duas ordens de problemáticas, cada uma delas relacionadas com diferentes bordas do dizível na regularização primeira do rock nacional. A primeira tem a ver com determinadas formas do patético, e não se relaciona apenas a narrativas em que alguém morre, mas a vários outros objetos e tópicos relacionados com a emotividade, e inclusive aos modos de representar as relações amorosas. Por meio dela, o rock argentino foi guardando um distância indiferente em relação a formas da canção romântica e do melodrama perceptíveis em outras expressões da cultura de massa. A segunda nos leva aos modos de encenação do político. Ambas, veremos, se relacionam a formas predominantes de representar os seres e seus vínculos, bem como a posições de sujeito mobilizadas nos processos de regularização que estudamos neste trabalho. Da primeira começaremos a nos ocupar neste capítulo, e da segunda a partir do Capíttulo VIII. A abordagem deste capítulo demandará revisitar o

\footnotetext{
${ }^{23}$ No capítulo IX retomaremos essa concomitância a partir de outra leitura.
} 
pouco estudado problema do melodramático no rock argentino, considerando teorizações sobre o melodrama na crítica cultural. Haverá um momento dedicado a isso, mas depois de uma apresentação de diversos casos e modalidades.

\section{Faits divers}

Em 1968 é publicado o segundo LP de Los Gatos, Viento, dile a la lluvia. Nele aparece gravada a canção "Los payasos no saben reír", que provavelmente integrava um grupo de composições que formavam parte do repertório da banda antes de começar a gravar (Conde, 2007, 55-63). Como veremos no ítem 6 deste capítulo, ao nos referirmos mais extensamente a esse grupo e a seu compositor e líder, Litto Nebbia, essa proveniência coloca a composição num espaço ainda transicional em direção à configuração do campo.

Soa uma melodia suave, que no encerramento da música confluirá com uma harmônica muito "dylaneana", traços ambos que, independente dos espaços em que tenha sido executada, colocam a canção claramente fora da expetativa de uso dançante da “música para jovens". Uma voz que se encena na $1^{\mathrm{a}}$ pessoa desenvolve um breve relato. Assistindo o espetáculo de um palhaço, vê que ele chora, que não é feliz. Depois, sabe pelos jornais que o palhaço morreu. A afirmação que dá título à música, sobre o não saber rir dos palhaços, é reiterada e parafraseada com insistência ao longo do canto todo. Em certo modo, há um relato de aprendizagem, já que o locutor afirma "recién cuenta me doy". A canção apresenta também, de modo incipiente e ainda muito elementar, uma polaridade de perspectivas fortemente implantada no rock no mundo, de modo geral, e que também irá adquirindo força no rock argentino. No capítulo próximo ampliaremos a explicação desse traço e das suas realizações especificas no rock argentino, antecipamos aqui que se trata de uma distinção entre o ser que consegue "ver", "perceber" e o conjunto ordinário ao qual essa visão escapa. No caso desta letra: "Toda la gente aplaudió y nadie cuenta se dio". Essa polaridade também promove, em alguns casos, a confluência empática do ser visionário com alguma entidade posta como diferente, o que acontece parcialmente nesta música com o palhaço. 
Este é o único relato que inclui, ou sequer menciona, o falecimento de um personagem, posto em ato ou evocado, que temos achado em todo o primeiro corpus que referimos no capítulo anterior: a revisão exaustiva de tudo que foi gravado até a dissolução das primeiras grandes bandas, em até 1971 (os exemplos que referimos no início do capitulo, de mortes-não-tão-mortes, são todos posteriores). É, por sua vez, uma música que está tão "registrada" em disco como as outras de Los Gatos, mas que é muito pouco referida. Nenhum dos autores que lemos e que escreveram sobre Litto Nebbia (ÁBALOS, 2009; GRINBERG, 2008; DÍAZ, 2005; CONDE, 2007) a menciona. É curioso que o último deles dedica uma parte do seu ensaio à "candura" de algumas composições primeiras do músico, o que se ajustaria perfeitamente a esta, que não é comentada. Também não aparece em antologias posteriores em CD; enfim, levando em conta que não tudo pode ser igualmente lembrado no desenvolvimento de uma memória do campo, trata-se de uma música bem mais esquecida do que outras.

Ao incluir a passagem sobre a morte do palhaço, a canção, que já é próxima, tanto na sua materialidade musical quanto na sua letra e na corporeidade da voz que canta, de manifestações da canção popular atravessadas pelo melodramático, ganha uma das características que Martín Barbero (2008, p 237) vê precisamente nos gêneros da cultura de massa que recolhem aspectos do melodrama, "dissolver lacrimosamente os impulsos trágicos despolitizando as contradições cotidianas". Cremos que é nessa linha que podemos encontrar coerência entre diversos objetos e temas evitados no discurso do primeiro rock argentino. Esquivamento, insistimos, indiferente, porque não tem a estridência programática com a qual os músicos do campo em gestação se diferenciam da “música para jovens" convencional que faz parte de seu espaço evidente de coexistência. Precisamente pela sua indiferença, esse esquivamento deixa marcas tanto da presença da coisa evitada quanto do deslocamento em relação a ela.

No caso que estamos considerando, por exemplo, pensamos que a morte é deixada atrás na própria música. É na própria composição, com sua aparência de estabilidade dada por ser uma unidade textual, que podemos observar a concorrência contraditória, a passagem de alguma série da canção de exagero sentimental para a série que está em formação e que terá outras prioridades patéticas. Com efeito, a morte do palhaço é mencionada e logo fica atrás, sem qualquer imagem ou dicção de angústia por essa falta. A voz continua com o tópico insistentemente repetido que dá título à música, e tratando 
da aprendizagem realizada, transformada logo em ensinamento para um interlocutor encenado na última estrofe.

Outro caso em que irrompe um tópico relacionado aos absolutos melodramáticos é a música "Proyecto de un ladrón prisioneiro", de Pajarito Zaguri com a banda La Barra de Chocolate. Foi gravada em 1969 no único LP do grupo. Pajarito, cujo nome era Alberto Ramón García, está presente, como Nebbia, no que depois vai ser o campo do rock argentino desde a sua pré-história. Junto com Moris e Javier Martínez integrou, entre 1965 e 1966, a banda Los Beatniks, que grava o primeiro compacto de rock em castelhano atribuído pela tradição crítica ao futuro "rock nacional". A trajetória posterior de Zaguri não é muito bem sucedida, ficando num segundo plano em relação às bandas e solistas que atingirão mais público. Um dos seus compactos, "Alza la voz” ganhou um prêmio e atingiu uma alta cifra de vendas, mas o LP em que está a música da qual trataremos é muito pouco lembrado.

A figura do ladrão, como em geral do delinquente comum, é praticamente ausente do rock argentino das primeiras épocas, pelo menos até a década de 80 . Também o cárcere como lugar de reclusão. Há, sim, alusões às frequentíssimas detenções e ultrajes policiais dos quais os roqueiros eram objeto por usar cabelo comprido ou determinadas vestimentas, ou ao perigo de ser detido na rua ( por exemplo, "Yo vivo en una ciudad", de Pedro e Pablo, ou "Blues de la amenaza nocturna", de Javier Martínez). Mas o crime, nem romantizado como resultado de alguma injustiça nem vilipendiado, definitivamente não é um tópico presente, diferentemente do que aconteceu no tango e do que acontecia em outras formas da canção popular em espanhol que circulavam na mesma época.

A composição de Zaguri sobre o prisioneiro começa com pleno ritmo e instrumentação básica de rock (bateria, baixo e guitarra elétrica), inclusive com efeitos de distorção. Há um recitado no início, em que o tom monocórdio contrasta com a marcada afetação estilística do texto. O prisioneiro parece referir-se a uma ave que avistou da janela da sua cela:

Traté de seguir su vuelo con mis ojos, pero el duro cemento que presidía los barrotes no me dejó. Mis manos se aferraban y palpaban la fría humedad del áspero hierro. El ave ya había volado. Vuela. Vuela tú que puedes, bien alto, entre las nubes y el cielo, y todas esas cosas que le dan color al firmamento. Colores precisos, lógicos y extraños. Cuántos como tú pueden oler el viento y beber de los arroyos. Cuántos podrían hacer las cosas que tú haces, y se olvidan. Se olvidan de cómo mirar a las nubes y el mar. Vuela. Vuela tú, que puedes. Pero, pero bien alto. 
Vários traços aproximam esse recitado do discurso folhetinesco, do qual parece uma dessas mimeses que lemos em romances de Manuel Puig. No início descritivo, a adjetivação anteposta e constante: "duros barrotes", "fría humedad", "áspero hierro". Depois, o emprego de "firmamento" para referir-se à abóbada celeste e a reiteração de unidades em sequência, como "vuela" e "pero". Depois da "rara avis" que representa, no rock argentino, um recitado nesse estilo, a música se desenvolve como um rock clássico, com uma letra extremadamente simples que não faz qualquer referência nem à condição de ladrão nem à situação carcerária. Em certo modo, também nesta música, como na anterior que discutimos de Nebbia, vemos uma presença e em seguida um apagamento de tópicos e de modulações do emotivo que ficarão silenciosamente ausentes do rock argentino.

Além de não haver mortes individuais narrativizadas, de não haver encenação de delitos nem de entrada no mundo do crime, não há prostituição, nem estupros, violência doméstica, doenças graves, objetos que só aparecerão no denominado "rock argentino" quase vinte anos depois, com o campo já extremadamente diversificado no seu alcance social, em um pais profundamente transformado. O problema do melodramático neste campo requer, então, ser indagado, sobretudo na época da sua primeira consolidação. É o que faremos no item seguinte;

\section{O melodramático e o "progressivo" argentino}

A tese de Diego Colomba (2010) tem, dentre outras virtudes, a de ter percebido a necessidade de interrogar o rock argentino em relação com o discurso melodramático. $\mathrm{O}$ fato de ser o único estudo sobre o gênero em que o problema é abordado, logo no contexto de um doutorado em estudos literários, é mais um indicador, desta vez no nível da crítica, dessa relação de indiferença que temos postulado. Exporemos brevemente o modo como o pesquisador aborda essa relação, delimitando em que aspectos concordamos e em quais não com a sua leitura.

Colomba (2010, p 78-81) apresenta a questão do melodramático precisamente no lugar que despertou nossa inquietação: as relações contraditórias do denominado "rock 
argentino" com outras modalidades da canção popular na cultura de massa, tais como o bolero, o tango ou os diferentes desenvolvimentos da canção romântica. A especificidade do rock nacional na sua relação com o melodramático estaria, para o autor, na construção de "una fuerte tensión entre la lógica del mundo del deseo y la lógica del mundo de las convenciones sociales".

Concordamos com Colomba em que há traços do melodramático, como o direcionamento a um efeito emocional procurado e uma certa retórica do excesso, presentes em muitas modalidades da canção popular contemporânea e ainda no rock argentino. Porém, diferimos na ponderação de outros aspectos. Não vemos, como ele, uma "estilização extrema" das vozes no canto, menos ainda na comparação com o bolero ou o tango canção. E fundamentalmente, nossa opinião se afasta um pouco da do autor no que tem a ver com as visões de mundo e com determinados objetos. A respeito, em um ponto da sua explicação, lemos:

La búsqueda de los rockeros de una relación autónoma con el placer y su contraparte, la felicidad negada que ocasiona el sufrimiento humano, tópicos a los que aludimos, conectan al género con el núcleo emotivo del melodrama. (COLOMBA, 2010, p 80)

E em nota de rodapé:

Sí se distanciará del melodrama, al menos explícitamente, en algunos de sus ideologemas claves, al punto de oponérseles: el triunfo de la virtud, el castigo del vicio, la sexualidad como pecado. En esa tensión entre el mundo del deseo y el mundo de las convenciones sociales, se impondría el primero en un gesto de rebeldía que no claudica ante las demandas del status quo. En ese sentido, el rock nacional no sería, al menos explícitamente, conciliatorio como otros géneros masivos como la telenovela, para dar un ejemplo. (ibid, p 80)

Se a procura de uma relação autônoma com o prazer é um traço ideológico tão central no rock argentino ${ }^{24}$, então essa é uma característica que o afasta da tradição melodramática, não que o aproxima dela. O que Colomba agudamente percebe como lugares do melodramático dos quais o rock argentino se distancia, isto é, a vitória da virtude, a punição do vício e o sexo como pecado, não são características menores, elas fazem parte do que diversas teorizações apontam como mais central no melodrama, e dos modos como o melodramático tem acolhido, na cultura de massa e nos seus antecedentes espectaculares, discursos de disciplinamento social que não se advertem no rock

\footnotetext{
${ }^{24}$ No capítulo próximo explicaremos por que não vemos o hedonismo como nodal na época toda que abordamos neste trabalho.
} 
argentino das primeiras épocas. Para Brooks (1974, p 342), o melodrama clássico, de modo geral, tendia a ser principalmente a dramaturgia da virtude desprezada e finalmente reconhecida. Nessa linha, os "absolutos morais e psicológicos", bem como o maniqueísmo e a polarização entre o bem e o mal, são componentes essenciais no desenho de tramas, na composição de personagens e de seu discurso. Os papéis prototípicos que Thomasseau (1984) vê no melodramático (teatral e não teatral) para a composição de enredos e personagens revelam também esse caráter. E essas características que, apesar da reconfiguração que implica a canção em relação ao drama, são claramente visíveis no bolero, na canção de tradição romântica e em algumas linhas do tango, são muito estranhas ao discurso do primeiro rock argentino que, como veremos ao longo deste trabalho, parece ter centrado seus dilemas em uma dimensão autorreflexiva e não em relação a uma dicotomia entre vício e virtude, entre vilãos e heróis, sobretudo se ela é concebida como qualidade que ganhará reconhecimento e compensação social.

Alguns tópicos mais especificamente associados ao melodramático na canção, tais como o amor fracassado, a traição (OLIVEIRA, 2008), a impossibilidade da realização amorosa ou a força do destino (ALVES, 2015, p 484) também são infrequentes no rock argentino das primeiras épocas. Um caso interessante para observar como esses lugares resultam uma "borda" silenciosa na discursividade do rock nacional é o do que se denominou brevemente a "Trova Rosarina", no início dos anos 80, logo quando vai ter início a massificação e diversificação do campo. Desse conjunto de músicos da cidade de Rosario, alguns vão continuar conhecidos como "do rock" e outros em uma relação duvidosa, limítrofe, ou diretamente por fora. No Festival de Rock de La Falda de 1982, o cantor Juan Cralos Baglietto ganha o prêmio revelação, cantando com uma banda que incluía o até então desconhecido Fito Paéz, que depois viria a ser o principal referente de uma vertente do rock a partir dos 80 . Dotado de uma voz muito cultivada, Baglietto não era compositor, e incluía no seu repertório canções de Páez, mas também de outros compositores da "trova" que resultariam estranhos ao gênero, mesmo depois da diversificação do campo do rock nessa década e na seguinte.

Algumas músicas eram de Adrián Abonizzio, pequenas crônicas como "Mirtha de Regreso" ou "Historias de Mate Cosido". Em ambas, os personagens são delinquentes, os primeiros que aparecem no gênero depois (muitos anos em termos de música feita por jovens) daquele esquecido que citamos de Pajarito Zaguri. Em "Mirta...", cuja letra tem uma sequência narrativa particularmente nítida, é contada também uma infidelidade 
amorosa (embora se apresente como compreensível pela prisão do homem) ${ }^{25}$. A segunda resgata o personagem do bandoleiro Mate $\mathrm{Cosido}^{26}$. Em outra música, "El gigante de ojos azules", composta a partir de uma tradução do poeta turco Nazim Hikmet, Baglietto canta uma história de abandono e traição amorosa nitidamente polarizada entre virtude e vileza. E a gravação que levou esse cantor mais longe do gosto consolidado no rock argentino foi "Era en abril", de autoria do também rosarino Jorge Fandermole, em que uma voz masculina e uma feminina contam que seu bebê morreu antes de nascer.

Cremos que o trânsito de composições como essas pelo campo do rock argentino foi possível precisamente como sinal de que, em 1982, domínios discursivos mais diversos começavam a manifestar-se nele. E é significativo que, mesmo em 1982, essas canções e logo depois o próprio Baglietto, tenham ficado num espaço limítrofe, um "quase fora" dito com rodeios, nas considerações do público e da crítica roqueira.

Também nessa linha de relação contraditória com o melodramático podemos avaliar um outro caso de distanciamento, o do cantor e compositor Sandro, nos primeiríssimos momentos, quando o campo ainda se encontra em estado germinal. Roberto Sánchez, de apelido artístico Sandro, começou cantando rock'n roll em inglês no início dos 60, época em que foi muito próximo de músicos que depois conformariam o "progressivo" que derivaria em rock argentino, compartilhando com eles inclusive o espaço de um dos primeiros bares que foram lugar de confluência (ÁBALOS, 2009, p 8083). No período em que o campo vai se formando e acontecem as primeiras gravações, Sandro não faz parte dele, e entra de cheio no repertório da indústria discográfica e do espetáculo em diversos estilos. As narrativas consolidadas na crítica jornalística e biográfica do campo sobre esse "não pertencer" de Sandro destacam sua absorção pelo “convencional" promovido pela indústria cultural. Por exemplo, este julgamento citado

\footnotetext{
${ }^{25}$ Gravada no final da ditadura militar, "Mirtha de regreso" contém imagens que aludem ao clima de opressão sob aquele regime, mas também indícios referenciais suficientes para situar o personagem masculino que saiu da prisão como autor de pequenos crimes, não como ex preso político. No entanto, muitas vezes nos encontramos com afirmações, de ouvintes e de comentaristas, orientadas para a interpretação de que se trataria de um militante que saiu em liberdade. A omnipresença do terrorismo de Estado como assunto logo nos primeiros anos 80 , em que os piores horrores saiam à luz pode ter incidido sobre essa leitura, mas cremos que também pesou o fato de ser completamente inesperado que esse tipo de personagem ganhasse corpo em uma voz juvenil ligada à musicalidade do rock.

${ }^{26}$ David Segundo Peralta, chamado assim por causa da cicatriz que tinha na cabeça (parte do corpo que, na Argentina, pode ser denominada metaforicamente como "mate"). Mate Cosido, que viveu na primeira metade do século XX no nordeste do país, foi do tipo de delinquente romantizado em torno do qual é construído um relato heroico. $\mathrm{O}$ tango e, em menor medida, o folklore argentino, adotaram várias vezes personagens desse perfil, que para o rock argentino da época eram uma novidade. Muitos anos depois, em 2001, o compositor e cantor León Gieco, que foi figura central do rock argentino nos anos 70, gravou a música "Bandidos rurales" na qual se refere a Mate Cosido e a outros.
} 
de uma revista por Díaz (2005, p 61): "la gran superficialidad, esa inyección de conformismo que siempre neutralizó cualquiera de sus atisbos de originalidad". Mas não se referem a seu trânsito pela balada romântica descarnada que, muito depois, nos 90 , diversas correntes do já muito diversificado rock argentino reivindicarão ${ }^{27}$.

Poderíamos especular se a ausência, no rock argentino "clássico", dos traços melodramáticos que estamos revisando aqui não tem a ver com algo que Martin Barbero (2008, p 205) aponta em relação às hierarquias do gosto no campo cultural: a desqualificação pejorativa que adquire o melodramático "com relação a tudo o que para a cultura culta caracteriza a vulgaridade da estética popular". Não nos parece que, no caso, esse caminho ilumine muito. Primeiramente porque, como já reconhecemos ao discutir a tese de Colomba, o rock argentino não está isento de outros traços de melodrama, tais como a retórica do excesso e os exageros patéticos em torno de outros objetos. Em segundo lugar, porque o rock argentino nascente não ocupa ainda, naquele tempo, um lugar de prestígio no campo da produção de bens simbólicos, sequer na sua acepção de "grande produção" (BOURDIEU [1971] 2010). Por outra parte, como outros movimentos que, no mundo, fizeram parte da renovação musical da época, o "progressivo" argentino poderia ter reorganizado em outros tons e orientações esses materiais e tópicos melodramáticos da tradição cantada. Por exemplo, no contexto de um movimento muito melhor posicionado em relação ao prestígio no campo cultural, a Tropicália, Caetano Veloso gravou em 1967 uma versão da ultramelodramática “Coração materno" de Vicente Celestino, com um arranjo que, segundo o próprio músico, "criou uma atmosfera de ópera séria (sem, no entanto, deixar de lembrar trilhas de filmes de Hollywood), restituindo dignidade e conferindo solenidade à canção execrável" (VELOSO, 1997, 288). Mas o rock argentino, que nas suas primeiras etapas estava muito longe do reconhecimento que a Tropicália já ostentava em setores da classe média intelectual, nunca realizou esse tipo de abordagem consciente do passado musical argentino; pelo contrário, foi, como bem aponta Colomba (2010, p 42), fortemente autorreferencial.

\footnotetext{
${ }^{27}$ Assim, o CD Tributo a Sandro - Um disco de rock reuniu, em 1999, dez bandas e dois solistas dentre o mais cotado do rock argentino da época. Nele, canções de Sandro, maiormente da sua linha romântica, são vertidas a sonoridade roqueira. Sandro faleceu prematuramente por epog em 2010.
} 


\section{Formas do amor em cena}

Pensamos que as ausências de vários tópicos e objetos que, como temos observado, o rock argentino não comportou nas suas primeiras épocas confluem para um modo predominante de representar os vínculos amorosos, modo que é congruente com a centralidade que adquire um tipo de processo de mudança no indivíduo, que será o problema central do capítulo seguinte. $\mathrm{O}$ amor fracassado e a traição nunca são tema. $\mathrm{E}$ também não é tema seu aparente contrário: a história de amor bem-sucedida. Quando o amor por alguém se celebra, é já no estado de amor, não a narração de como ele se atinge.

É oportuno trazer aqui, para apontar semelhanças e diferenças, uma outra situação histórica de diferenciação em torno do melodramático. Frith ([1998] 2014, p 288-291), tratando sobre a canção popular urbana estadunidense das décadas de 1920 e 1930 propõe que o blues se diferenciava da canção branca em que, embora se referisse também ao relacionamento amoroso, não estava carregado das inflexões de autocompaixão, nem do fatalismo e da desilusão que abundavam nessa última. O senso de humor e a ambivalência, no blues, não davam lugar a esse tipo de expressão patética.

No primeiro rock argentino aconteceu uma exclusão análoga, mas não em direção ao senso de humor nem ao jogo com uma ambivalência amorosa. O que foi configurandose no campo que estamos estudando foi o amor representado como vivência de um dos seres envolvidos, daquele a cuja perspectiva se relaciona a voz enunciadora, e incluindo sempre ou quase sempre uma instância autorreflexiva. De algum modo, que varia de composição a composição, o ser amado ou o próprio amor que se sente fazem parte de uma experiência autocentrada, que pode ser uma percepção de algo novo, um deslocamento, uma aprendizagem, mudanças que em muitos casos passam a ser o tópico dominante. Isso não resta espaço à figuração do amor, mas explica que não se focalizem ciúmes, traições, encontros ou abandonos, que requereriam um dimensionamento maior, eufórico ou disfórico, da perspectiva do par. Assim, chega a haver expressões de desapontamento amoroso, mas enquadradas no ganho de uma convicção, por exemplo, em “Ayer nomás", tanto no original de Moris quanto na versão levemente modificada por Litto Nebbia, ou na música de Spinetta com a qual começamos o percurso deste capítulo (“Cementerio Club”). Também em relação ao mesmo foco autorreflexivo vemos o fato de que dificilmente se narrativiza um vínculo amoroso nas suas fases. Se há uma 


\section{cronografia do amor no primeiro rock argentino, ela é mais a de um estado presente, ou evocado, ou desejado, do que a de um percurso.}

Inclusive quando se canta uma admiração extasiada pelo ser amado, como em "Natural", de Tanguito, ou "Muchacha (ojos de papel)", de Spinetta (gravado com Almendra), ela é principalmente uma exposição da potencialidade criativa ou visionária do locutor-artista representado na voz e pela voz. O único desses retratos em que vemos a criatividade como deslocada também para o ser amado é "Catalina Bahía", de Miguel Cantilo (gravada com Pedro y Pablo), a música mais nitidamente erótica desse período e, não casualmente, de uma dupla que também, como veremos no Capítulo VIII, se localizou, por outros motivos, nas bordas do campo.

Conhecer o repertório e os artistas do rock argentino nas suas primeiras épocas leva a notar e confirmar que, inclusive até os 80 , a imensa maioria dos cantores e a quase totalidade dos compositores e músicos foram homens. E cabe dizer que em todas as composições que conhecemos com temática amorosa o ser representado pela voz se identifica, de diversas maneiras, como masculino. Poderíamos afirmar, então, que essa vivência autocentrada do amor que estamos descrevendo se relaciona a esse traço da enunciação? Dado que não foi um dos propósitos deste trabalho nem da pesquisa que lhe deu base problematizar a questão de gênero na discursividade que estamos estudando, não podemos dar a essa pergunta uma resposta adequada, que requereria uma investigação específica com uma abordagem integral e diferente. Mas podemos afirmar que, nos raros casos em que a encenação amorosa tem uma mulher como protagonista, não como objeto de amor do "eu" masculino mas como amor presente ou possível de outros, a focalização do amor como experiência autorreflexiva também aparece, só que dita, é claro, a partir de uma voz masculina, que explica ou que aconselha. Os dois casos que podemos mencionar na primeira época são "Elena”, de Manal, e "Laura va”, de Almendra ${ }^{28}$.

\footnotetext{
${ }^{28}$ A primeira é de autoria de Javier Martínez. A segunda, de Luis Alberto Spinetta, e a abordaremos amplamente no Capítulo $\mathrm{V}$ ao tratar sobre o disco em que foi gravada.
} 


\section{A pré-história e o corte. Enunciar-se em solidão.}

É importante observar que esse modo predominante de representar o amoroso é algo ao que a corrente que vai desenvolver-se como "rock argentino" chega muito rapidamente, mas que não é dado de início. Alguns dos primeiros compositores, apesar da sua juventude, vinham de práticas musicais anteriores, que deixaram marcas que subsistiram durante seus primeiros passos. É o caso de Litto Nebbia nos primeiros discos de Los Gatos y, em menor medida, de Tanguito. Ambos têm algumas canções centradas na polaridade do casal romântico e que manifestam alguns dos traços que foram ficando ausentes dos modos de pôr o amor em cena -e em voz- no primeiro rock argentino.

Litto Nebbia, autor, intérprete e líder de Los Gatos, vinha de encabeçar outro conjunto tido como parte de prehistória do rock argentino, denominado primeiro Wild Cats e pouco depois da chegada de Nebbia Los Gatos Salvajes, nome com o qual chegou a gravar um LP e um compacto em 1965. Banda surgida na cidade de Rosario, não apresentava ainda nenhum dos traços de busca de elaboração e experimentação que, como vimos no Capítulo II, delimitaram o "progressivo" que deviria no campo que estamos estudando. Tocavam em bailes e clubes um repertório que, segundo contam seus músicos em Ábalos (2009, p 42-45), combinava versões de Hollies, Animals ou da época inicial e mais simples de The Beatles com peças de estilo semelhante vertidas ao espanhol pelos mexicanos Teen Tops, e com músicas próprias que Nebbia ia compondo nessa mesma linha. Dessas canções, as que conhecemos por terem sido gravadas no disco de 1966 (e algumas delas também em um compacto) têm a demanda pela mulher amada como principal temática. Colomba $(2010,48)$ vê nelas um "extremismo sentimental" que remete ao bolero. Não estranhamos essa remissão, porque além das linhagens de música em inglês que já mencionamos no repertório desses músicos, os espaços de performance como os bailes e os programas de rádio e TV em que eventualmente apareciam eram lugar de confluência com diversas modalidades da canção romântica latino-americana.

No quadro do que aqui estamos explicando sobre os modos de pôr em cena o vínculo amoroso, e, principalmente, sobre a inserção do "estado de amar" entre as perspectivas de pessoa, resulta claro que essas canções de Nebbia estavam muito longe da centração de um ser (amante ou amado) em si próprio, com o amor como fonte de superação criativa ou de autoconhecimento. No entanto, mesmo nesse período em que o 
compositor e seus companheiros de banda ainda fazem música não concebida como "para escutar", nos termos que definimos no Capítulo II, item 2, a partir de Fischerman (2013), há alguns gestos que prefiguram um passo na direção de traços observáveis, depois, no que será a regularização discursiva dominante no rock argentino. O principal é que suas canções de amor não entram no padrão alegre e vivaz que a indústria fonográfica desenvolve e promove em primeiro lugar como "música para jovens". Havia, nas suas músicas, um dizer-se solitário que ia na contramão dessa demanda. Na versão em espanhol que Nebbia faz de "Under the boardwalk", de Arthur Resnick e Kenny Young ${ }^{29}$, ali onde a letra dos americanos descreve o encontro gozoso de um casal, Nebbia traduz "Me siento solo, sin um amor / me siento solo, bajo la rambla estoy / me siento solo, todos tienen su amor"30.

Enunciar-se em solidão parece ter funcionado como um acontecimento discursivo de limite, um "chega" que começou a conduzir em uma nova direção, embora ela não tenha sido a de um cantar melancólico de solidão, mas o da procura que iremos descrevendo a partir do capítulo seguinte. E parece ter sido um acontecimento com repetição em outros que tentavam afastar-se da demanda de alegria e candura juvenil, embora não saíssem, a princípio, da escassa elaboração musical. "Estoy muy solo" aparece, como gesto de extrema simplicidade, no relato de Pajarito Zaguri em Ábalos (2009), quando lembra como foi rejeitado, em 1964, por produtores de TV em uma prova para o "Club del Clan", programa que mencionamos no Capítulo II e que era a máxima expressão da produção "convencional" e conformista "para jovens":

Componíamos una canción que decía "estoy muy solo y cansado", con la misma música de Elvis Presley, bueno, ¡una letra de aquellas! Cuando escucharon esa letra los tipos se murieron y dijeron: -no, esa letra no puede salir ni ahí, ni en vivo se puede cantar esa letra- me dijeron - ni en vivo. Y tenían razón. (ÁBALOS, 2009, p 28)

Voltemos a Litto Nebbia, mas já em Los Gatos, em 1967, no bojo do momento inicial de conformação do campo como de "música para escutar", já em pleno convívio com o resto dos pioneiros em Buenos Aires, frequentando o circuito de reunião e experimentação formado por bares como La Cueva ou La Perla del Once. A produção de

\footnotetext{
${ }^{29}$ Gravada primeiramente pela banda estadunidense The Drifters em 1964, foi interpretada pouco depois pelos Rolling Stones.

${ }^{30} \mathrm{Na}$ mesma época, uma versão mexicana da banda Los Apson, titulada "Fue en un café" transforma a letra em uma narrativa de traição amorosa e abandono.
} 
Nebbia com essa banda nos três primeiros LPs, até a primeira breve separação em $1969^{31}$, pode ser vista como transicional em direção à regularização discursiva que irá se consolidando no "progressivo" e que já estava mais desenvolvida em quase todos os outros companheiros de rota, também incipientes. Nesse primeiro repertório de Los Gatos há, ainda, músicas que parecem compostas para dançar e também tópicos melodramáticos que foram ficando fora das primeiras etapas do rock argentino, como a história do palhaço que já comentamos, "El niño y el mar”, que abordaremos no Capítulo VI também como lugar de passagem, ou o fatalismo sentimental de outras que aqui não indagaremos, como "Una nube en tu vida", "Dónde está esa promessa" ou "De nuevo en el camino". Porém, dentre essas gravações há também muitas que no plano musical já se posicionam claramente como "de escuta" e/ou em cuja materialidade verbal podemos encontrar aspectos da procura que, como hipotetizamos neste trabalho, teve lugar na discursividade do nascente rock argentino.

Dentre essas músicas, está "La balsa", primeira que gravaram Los Gatos, y que a construção histórica do campo sobre si mesmo monumentalizou como "ponto inicial". Seu primeiro verso tem muito a ver com o que acabamos de discutir: "Estoy muy solo y triste acá, en este mundo abandonado". A partir da abordagem que aqui estamos fazendo, na qual a observação das regularidades, das exterioridades e das indiferenças permite questionar a estabilidade dos agrupamentos do discurso institucionalizados, esses primeiros versos, longe de serem um início, são ponto de uma repetição sem original localizável, funcionando na confluência com outros materiais em que foi derivar a ruptura que essa repetição representou. Nesse novo espaço de regularidade, a solidão será construída como objeto em articulações muito diferentes da demanda amorosa, como veremos no capítulo seguinte.

O outro autor de "La balsa" foi José Alberto Iglesias, conhecido como Tanguito, Como antecipamos, também ele, que frequentou os palcos de bailes e rádios em formações semelhantes à de Los Gatos Salvajes, mostra, já na sua produção roqueira, traços que fazem parte do que aqui vemos como exterior ao que vai resultando dominante no primeiro rock da Argentina. Muito menos que Nebbia, mas podemos apontar a história

\footnotetext{
${ }^{31}$ Naquele ano vários dos componentes da banda viajam e na volta se reúnem novamente, mas incorporando um novo guitarrista, Norberto Napolitano, que passou para a história do rock argentino como Pappo, e que mudará o estilo da banda em direção a um rock mais pesado até sua dissolução em 1970. Pappo faria depois uma longa carreira solista, que passaria pelo blues e o metal. Nebbia continuou também como solista, afastando-se crescentemente da sonoridade roqueira.
} 
de abandono em "Sutilmente, a Susana" e em "Billy el náufrago", música que abordaremos no próximo capítulo juntamente com "La balsa". E, paradoxalmente, é em uma música de Tanguito do final da década de 60, talvez sua composição mais famosa, com letra do poeta Pedro Pujó, que vemos uma das manifestações mais nítidas do amor como estado relacionado à criatividade do indivíduo.

"Amor de primavera" poderia anunciar, pelo seu título, uma narração de apaixonamento naquela estação do ano. Mas é um enfoque completamente diferente dessa expectativa. A voz fala para alguém, a quem anuncia que pode escutar "un amor de primavera que anda dando vueltas", para logo depois dizer que o ser que ganha corpo na voz também o escuta. Esse amor como força que ronda, não identificado com ninguém, é o que introduz uma figuração relacionada a uma experiência perceptual superior para o indivíduo, tirando de foco a vinculação com um ser amado específico. Beber uma taça do barril de chuva leva ao contato com um ser especial, "el hombre de cirstal", e ao estabelecimento de uma linha "directa al infinito". O "tu", corpo solicitado pelo canto, é posto figurativamente numa confluência de tempo e espaço que convergem nele como ponto central. Uma das imagens mais representativas da centralidade do indivíduo em relação ao entorno que descreveremos nos capítulos IV a VII. A citação final de The Beatles, um deslocamento que reorienta profundamente o enunciado em inglês, é emblemática desta particularidade do rock argentino primeiro.

Com efeito, "aquí, allá y en todas partes", verso que Tanguito acrescentou, no canto, à letra de Pedro Pujó, alude à canção "Here, There and Everywhere", de Paul McCartney, gravada no LP Revólver, de 1965. A tradução do título já tinha sido nome do primeiro ciclo de recitais, de alcance extremadamente reduzido, que, como mencionamos na Introdução, os pioneiros do progressivo tinham oferecido em setembro de 1966 no Teatro de la Fabula, isto é, já estava relativamente fraseologizado no pequeno núcleo. É interessante observar que, na música de McCartney, a sequência de espaços "here / there / everywhere" aponta todos os lugares em que o eu do canto quer ter o ser amado, a cuja devoção está orientada a canção. Diferentemente, sua inserção na música de Tanguito orienta esses "aqui, allá..." para uma figuração completamente diferente, sem referência a um vínculo amoroso e centrada em uma experiência perceptual do ser singular. Vemos essa transposição como um dos acontecimentos discursivos que, como aquele de “enunciar-se em solidão", vão marcando uma nova direção. 


\section{Sem fatalidade}

A grande diversificação e a expansão maciça do campo do rock argentino nas décadas de 80 e 90, sob outras condições de produção, vai fazer com que as bordas e exclusões que observamos neste capítulo já não se percebam, e muito do que não aparecia depois apareça. A ampliação a outros setores sociais em um país já muito mais desigual, vai trazer novas vozes e novas demandas de patetismo.

O progressivo das primeiras épocas parece ter evitado os heróis, os mártires, os exemplos de virtude, os vilãos, bem como os sentidos de compensação moral e de fatalismo que lhes são relacionados na tradição melodramática. Cremos que o foco de interesse na mudança crítica do indivíduo, que, como sustentaremos no capítulo seguinte, se relaciona ao que vemos como dominante em um embate de posicionamentos, se relaciona com essas quase exclusões. E o tipo de representação do vínculo amoroso que temos postulado como característica se vincula a uma representação da mudança como primeiramente auto-reflexiva. 


\section{Capítulo IV \\ Observando a regularização \\ (Primeiro percurso)}

Neste capítulo apresentaremos um conjunto de regularidades que observamos no corpus correspondente aos primeiros anos do "progressivo" argentino, aquele que, como explicamos no Capítulo II, consideramos exaustivamente até 1971. Os três capítulos que seguem também abordam composições desse corpus, mas é neste que desenvolveremos a explicação de base sobre o que consideramos traços articuláveis, pela sua repetibilidade, em uma hipótese sobre a regularização discursiva nessa primeira época do rock argentino. Referimo-nos a uma relativa estabilização de objetos e de perspectivas em relação a eles, a disposições análogas entre instâncias de pessoa e aspectos de espacialidade e temporalidade representadas, e à percepção de pré-construídos que parecem dizer respeito a uma necessidade de transformação do ser e de seus vínculos que ganha formas específicas. Como antecipamos também no Capítulo II, o campo que estudamos se enquadra, independente da consciência que disso tivessem seus protagonistas, em um processo de questionamento político e cultural que se interroga pelas possibilidades do indivíduo para agir e para modificar mediante sua ação. Não é de estranhar, em consequência, que problemáticas desse tipo impregnem as vozes do que se propunha como "música para escutar" e, ao ter voz, como lugar de dizer.

O capítulo se dividirá em duas amplas seções. Na primeira, realizaremos um percurso por uma série de composições que nos permitirá ir apresentando os traços das configurações que propomos como regulares. Não se trata de todas as músicas do período em que observamos esses traços, o qual levaria a uma exposição extensíssima e repetitiva, mas de uma seleção daquelas que nos permitem expor cada um desses traços em recorrências e variantes, bem como mostrar algumas mudanças e evoluções. Levamos em conta, também, que várias outras composições do mesmo período serão abordadas nos três capítulos que seguem. Na segunda seção, propomos relações entre o observado nas músicas e diferentes aspectos da circulação discursiva e do confronto ideológico no campo intelectual e na cultura de massas, tentando caracterizar forças dominantes e tendências contraditórias na regularização, e hipotetizar posições de sujeito. 


\section{A configuração da mudança crítica}

\subsection{Nascer, sair. Passando por si.}

A composição "Porque hoy nací", na sua gravação no primeiro disco de Manal, é uma das saliências por onde pode começar a ser abordado o processo de regularização que tentamos caracterizar. Desenvolvida completamente sem baixo nem bateria, com uma marcação rítmica instigante, é um blues de atmosfera estranha. A voz de Javier Martínez ressoa como protagonista absoluta. Carnicer (2015: 7) a caracteriza como "un plan interpretativo devocional alcanzando una nota MI grave con el acompañamiento del teclado". Efetivamente se aproxima de uma fala litúrgica, prolongando as sílabas. Prolonga também algumas vogais finais, sobretudo um "o" final que, ao longo dos versos, vai se fazendo quase lúgubre, fantasmático. Esse conjunto de traços sonoros contribui para recortar um ser sozinho em cena.

Esse ser personagem se apresenta a si próprio, e o faz descrevendo um processo autorreflexivo. "Hoy..." é a primeira palavra, que localiza temporalmente esse processo, palavra que se repetirá sendo a que mais prolongação atingirá no canto arrastado.

O nascer que se anuncia pode mais ser visto como uma mudança que como um início total. O ser é anterior a esse nascer: alguma coisa já “le pasa”, não tem morada, está sozinho. O nascimento é uma transformação que, contraditoriamente, tem como traço um acesso maior a si mesmo: adivinhar o que acontece consigo, superar o próprio nome (como tal, necessariamente externo). O sol e o despertar aparecem associados a essa transformação.

Essa transformação passa por si mesmo, mas, por ser novidade e transformação, tem algo de ruptura, de conflito. $\mathrm{O}$ sol pode queimar, e foi um vento (dos vivos, mas com som lúgubre na voz de Martínez, e na de quem forme "corpo" com essa voz na escuta) o que fez acordar.

Uma configuração análoga, encenando um conflito semelhante, é exposta de modo muito mais extenso em outra "recitação de si", da mesma época: "De nada sirve", de Moris (pseudônimo de Mauricio Biravent). Uma voz que não se interrompe durante 
sete minutos, acompanhada apenas pelo violão que rasga, percorre várias alternativas sobre o que fazer diante do tédio e a angústia. Também emparentado com a dramatização, diferentemente da voz de Martínez em "Porque hoy nací", o monólogo de Moris não se representa como um só em cena, mas transita pelas inflexões dos outros personagens da cenografia enunciativa: os "outros" que critica e o denominado como "amigo" ("te doy un consejo, aunque yo consejos no doy”). Assim, o “¿Qué pueden hacer?” vira um “¿Qué puedo hacer?" em um tom mais agudo, de lamento nervoso. E as recomendações para o amigo vão dando lugar a uma forma de diálogo em que se alternam a referencia a si e à $2^{\mathrm{a}}$ pessoa.

O refrão da música é também a reiterada conclusão do debate angustioso: "De nada sirve escaparse de uno mismo." Não cabe escapar de si, mas sim sair de si, e na diferença entre esses dois movimentos se constrói uma oposição que relaciona essa música de Moris com a regularidade que estamos observando. "Nada sirve si uno lo usa para la soledad interna". "Escaparse" seria negar essa solidão refugiando-se em estímulos exteriores, inclusive pessoas, ou, é claro, produtos. Mas essa solidão é necessária, $\mathrm{O}$ amigo aconselhou: "fijate qué es lo que pasa cuando te agarra la soledad y te agarra el hastío" Esse ponto é necessário para chegar à indispensável crise, que é o momento mais intenso do canto declamado: "No puedo salir de mí, estoy muy encerrado en mi prisión de carne y hueso. No puedo salir, no puedo salir. Me voy a morir dentro de mí. Antes de morir yo quiero salir, ver las estrellas, el mar, me quiero ahogar. Y quiero salir, quiero vivir, me quiero ir, por favor, de mí. No quiero evasión, quiero vivir. ¿Qué puedo hacer?” Nota-se uma evolução no rogo. Esse "sair" não é evasão. A solidão completa que se experimentou ao "parar las maquinitas que llevas dentro de ti" e pensar e meditar em silêncio, levou a perceber a necessidade de "vivir", que o ser "aconselhado" expressa como sair de si mesmo. Porém, a resposta do "recomendador", que aparece em uma modalidade fortemente deôntica, é sair a viver de outro modo, integralmente por si: sem segurança nem propriedades, a puro risco (se reitera a construção "jugarse") e sabendo que isso significará ser maltratado.

O segundo exemplo que acabamos de dar, "De nada sirve", com a sua variação nas perspectivas pessoais, mostra que o processo que descrevemos não se restringe ao “eu”, ele pode apresentar-se em relação a segundas e terceiras pessoas. Por isso o denominamos como uma volta sobre si, não sobre o "eu". A transformação procurada, cenário e objeto do conflito, é deflagrada por um duplo movimento de distanciamento e 
aproximação de si mesmo. Não escapando desse "próprio interior" é que se conseguirá "sair", "nascer", “acordar", estar realmente "vivo". Observaremos, nos próximos itens e em capítulos posteriores, que, precisamente por uma de essas possibilidades ser uma segunda pessoa, essa crise pode ser veiculada mediante uma interpelação, o que nos levará para novas problemáticas relacionadas à dramaticidade no discurso do rock argentino pioneiro. E também veremos que o caminho em direção a si entra em relação com um "não fingir" de diversos matizes, que por razões expositivas preferimos introduzir depois.

Assim, nos itens que seguem desta seção, realizaremos um percurso por composições pioneiras do rock argentino rastreando o modo como esse processo nas instâncias de pessoa vai ganhando a forma de uma configuração relativamente regular, e como ele vai se relacionando a uma determinada representação de "momento de inflexão" e a determinados elementos do espaço.

\subsection{El lugar que yo más quiera}

Já no primeiro LP de Los Gatos observamos fenômenos que se relacionam à configuração que postulamos. Na composição "Ríete", como em outras da banda, o canto de Nebbia adquire, por momentos, traços de fala em público. Muito menos nítidos que no dizer de arenga que começa a caracterizar, na mesma época a Moris, Tanguito ou Javier Martínez, mas também crescentemente afastados do canto adolescente, entre sentimental e festivo, que ainda relacionava Los Gatos Salvajes à música dos "convencionais". A sugestão de rir é direcionada a um "tu”, para rir, em primeiro lugar, dos “outros”. Esses, localizados no lado disfórico da perspectiva do locutor, reúnem características de um antimodelo encontrável em composições do rock argentino de todas as épocas e mostrado como hegemônico no funcionamento social criticado.

Aparece também em "Ríete" um tipo específico de assimetria entre o anti-modelo e a perspectiva dissidente do enunciador, característico da discusividade do rock no mundo todo. Em muitas composições, alguma entidade singular ou coletiva aparece, como locutor ou como personagem, representada em contraposição com uma massa conformista, repetitiva, ou com um ser singular que sintetiza essa massa. Em alguns casos, 
a atitude a respeito do "enganado" é solidária, em outros casos, de desprezo, mas em todos aquele que não integra a massa tem capacidade de ver o que os outros não veem.

No caso, o engano dos "outros" é identificado principalmente com as guerras, mas há uma contraposição especialmente interessante para o que aqui nos ocupa: "Piensan en llegar a la Luna y no saben que a sus vidas no han podido aún llegar". Há um deslocamento representado, e mais importante que chegar longe (à Lua, meta da corrida espacial na época) é chegar à própria vida singular, descoberta que deveria preceder as outras. Essa meta, legitimada pelo locutor, não é atingida por eles, e isso se relaciona a um engano: crer que "vivir una vida es durar". Esse entendimento enganado não poderá aproximar-se da compreensão: “jamás te entenderán”.

No mesmo disco está "La balsa", publicada pouco antes em disco single, composta, como informamos no Capítulo III, juntamente com Tanguito. É inevitável, ao trazer "La Balsa" à tona, apontar que se trata de uma das músicas inseridas mais centralmente nas narrativas que constroem uma tradição do campo. Tida como "primeira" composição gravada (embora de fato não o seja, dois anos antes já tinha aparecido o simple de "Los Beatniks"), foi sem dúvida o primeiro relativo sucesso comercial do que viria ser o rock nacional. Reúne tópicos que seriam constantemente reiterados, como a solidão, a viagem e o naufrágio como metáfora de um perambular. Citada de modo mais ou menos evidente em composições posteriores de diversas épocas, é difícil encontrar histórias ou antologias do rock argentino que não a incluam.

No que diz respeito à configuração que nos interessa, vale começar apontando que, se o "naufragar" de "La Balsa" não tem rumo fixo, está longe de carecer de propósito. E aí temos um aceno do deslocamento para sí "tengo uma idea, la de irme al lugar que yo más quiera". O lugar de destino do ser é determinado a partir do seu próprio desejo. A atividade criadora, "construir uma balsa" é necessária para o deslocamento a esse lugar que não é possível atingir andando.

Não podemos deixar passar aqui, mesmo que não sejam nosso foco, valores específicos que a série lexical de "naufragar", "naufragio", "náufrago(s)" foi adquirindo na formação do campo do rock argentino e na sua metalinguagem crítica e jornalísticobiográfica. O grupo de pioneiros empregava o termo "naufragar" para as noites passadas sem dormir, percorrendo ruas, praças e cafés, conversando, tocando ou compondo (DIEZ OLEA, 2007; DÍAZ, 2005; GRINBERG, 2008). Há, inclusive, composições classificadas 
como "de naufrágios", porque, vistas na sua referência contextualmente imediata, tematizam ou descrevem o perambular pela cidade e por alguns bares que caracterizava a vida em comum de vários dos seus autores na época. Várias das que referiremos depois de Manal, Miguel Abuelo e Moris são enquadradas nesse tipo. O naufrágio é um tópico forte no relato que o campo foi construído acerca de si mesmo, nas revistas, histórias e biografias específicas. Ele destaca um perfil "boêmio", não isento de certa heroicidade. Se esse tipo de construção laudatória é esperável dentro do próprio campo, parece-nos problemático quando seus efeitos recaem na reflexão sobre ele em disciplinas acadêmicas. Com efeito, vemos que por vezes esse relato se naturaliza, e o "naufragar" é posto como "causa" da composição, que retrataria a "vida" desses músicos. Nós não negamos a produtividade que possa ter um enfoque genético para pesquisas com outros objetivos. Os modos de vida e de produção dos participantes do campo não deixam de ser um dado para nós, mas não são eles que explicam regularidades discursivas como as que estamos analisando, que, por sinal, se apresentam também em composições de autores e de bandas que não passaram pelas mesmas experiências. O "naufragar" e sua circulação na poética do campo nos interessa em função de como ele se articula, como objeto, com lugares de dizer, cenografias e configurações das vozes, como o estamos abordando neste capítulo.

Voltando, então, a "La balsa", cremos que o papel de transição que atribuímos a esta composição de Tanguito e Lito Nebbia no processo de regularização que estamos analisando resultará mais claro na comparação com outra música anterior de Tanguito $^{32}$, gravada como "Billy el náufrago" ou "Historia de un muchacho". Cremos que a descrição de personagem feita nessa música, embora leve o qualificativo de "náufrago", corresponde mais à comiseração com alguém preterido na vida do que com o tipo de ser que vive um deslocamento e atinge uma mudança. Ainda se lê nessa "história" um ser sofredor da canção romântica, que poderia fazer parte de uma música de Los Gatos Salvajes, ou, como afirma Lernoud (2009, s/n), "de Roberto Carlos en su etapa rockera". Sua solidão não é produtiva como encontro transformador consigo, consiste simplesmente em que ninguém o ama:

Esta es la historia de un muchacho que no tuvo hogar,

\footnotetext{
${ }^{32}$ Lernoud (2009) informa que em 1966 já estava composta e Tanguito a cantava.
} 
que vaga sin saber qué rumbo tomar.

Será porque tal vez quiera olvidar.

Anda por el mundo, triste, soñando encontrar

alguien que le dé su amor y que lo quiera amar.

Así olvidarás tu gran dolor.

Se encuentra solo, muy solo,

y nadie podrá borrar su soledad.

A solidão do ser retratado em "La balsa" se fundamenta numa rejeição consciente pelo mundo (a versão original dizia "en este mundo de mierda", sendo substituída por "en este mundo abandonado" para a gravação). E seu naufragar tem propósito. Embora sua transformação não atinja o grau de aprofundamento que se irá consolidando na discursividade do primeiro rock argentino, e não se apresente em relação com a multiplicidade de objetos e problemáticas que iremos mostrando nesta seção, está muito mais perto dessa configuração que a história de "Billy". Vale a pena, inclusive, contrapor essa primeira "História de um muchacho" precisamente com "Muchacho", de Moris, que abordaremos algumas páginas mais para frente, e na qual a discursividade pioneira do rock argentino já está plenamente consolidada. O "muchacho" de Moris amanhece depois do "naufrágio", e, como veremos, é depositário de um saber sobre a vida que faz com que o tempo lhe pertença. Entre esses dois pontos do caminho, podemos dizer que está o deslocamento que virou "clássico" em "La balsa".

\subsection{Correr, marchar}

O movimento autorreflexivo se faz mais nítido em uma composição do disco seguinte de Los Gatos, a música "Sueña y corre". Tanto a melodia quanto o canto de Nebbia criam uma atmosfera sonora muito mais próxima da candura inicial do que as duas anteriores que referimos. Não em vão é uma música muito pouco lembrada. Como em "Ríete", o locutor se dirige a um "tú" ao qual sugere atitudes a tomar. Essas sugestões, em um estilo estereotipado, repetem lugares comuns: "Sueña, sueña, sueña / sueña y nunca dejes de soñar / Sueña que algún día / tu sueño puede ser realidad”. Mas dentre eles aparece uma denominação interessante, e não tão comum, para o desejado / sonhado: 
"sueña que consigues lo que dentro de tu mente está." Se compararmos com "La Balsa", o "querer" do ser ("el lugar que yo más quiera") é aqui reformulado como um espaço interior. Nessa formulação "consigues lo que dentro de tu mente está" confluem, contraditória e instavelmente, um lugar comum que poderia funcionar inclusive no discurso para um modelo de jovem "bem sucedido" e uma denominação possível, ainda muito tímida e banal, para a "viagem interior", uma das formas que ganhará o "recurso a si” na discursividade dessa etapa do rock argentino.

Posteriormente, e ainda em Los Gatos, mas na sua etapa final, focalizamos a composição "Requiem para un hombre feliz". Está incluída no disco Rock de la mujer perdida, de 1969, e mostra uma sonoridade completamente diferente do costumeiro em Los Gatos, dada em boa medida pela execução de Pappo em guitarra elétrica. É uma música que já não oferece nenhuma ambiguidade a respeito de ser algo completamente diferente da música "convencional" para jovens, que, no caso de Los Gatos, sempre teve um resto de presença.

O título mostra uma certa ironia a partir da contraposição entre o "réquiem" como anúncio de morte e a felicidade atribuída ao tal "hombre". Esse homem, apresentado na segunda pessoa, é objeto de uma intensa interpelação, que começa precisamente pelo seu deslocamento no espaço: “¿Por qué marchas? ”inserido na segunda pessoa. O conjunto da canção parece indicar o homem como submetido a uma rotina própria do espaço urbano, de vender sua vida por um pagamento, deixando até a "alma": "ropa nueva, alma nueva / ya se ensuciarán”. Como ele, outros repetem a mesma vida e acabarão da mesma maneira.

O morrer em vida está relacionado a uma falta de propósito: "por qué marchas" imediatamente se continua em paralelismo como "por qué mueres". A massa conformista, como "los demás" de "Ríete", não têm resposta para dar ao "tu”. Porém, a interpelação ao "hombre feliz" é muito mais incisiva que a daquela composição. O "tu" não compartilha da perspectiva do locutor, e, relacionado a isso, não se formulam sugestões, antes bem perguntas que implicam uma avaliação. Cremos que esse modo de interpelação que, como veremos, na mesma época acontece fortemente em Moris, Tanguito e Manal, afeta a dimensão dramática do canto e da interpretação. A fala e a construção do "tu" já não parece confluir com um possível ouvinte, ou com o público direto em uma execução em um bar ou em um show. É como se um personagem fosse trazido à cena para ser exposto e criticado. Nesse sentido, se emparenta com modalidades do tango e do drama 
popular, cujas vinculações com o primeiro rock argentino abordaremos amplamente no Capítulo VII.

"Requiem para um hombre feliz" vai se relacionar com a configuração que estamos caracterizando também a partir de outro objeto de discurso: o sol e sua relação com a necessária ruptura crítica. Essa mudança não acontecerá com o ser interpelado, e essa impossibilidade se apresenta da seguinte maneira: o sol, que viu todos nascerem, não brilhará novamente para o "tu", não estabelecerá uma relação de "par a par" e de encaminhamento direto. Não apenas o "tu", muitos outros perderão essa oportunidade, perderão esse "sol-para-si". E vemos a conclusão "el hombre no sabe ganar", como um eco contraditório de discursos de mercado direcionados a construir uma identidade juvenil que procura o sucesso e o progresso na vida. Algo semelhante ao que apontamos a respeito de "Sueña y corre", e que emerge em diversas composições de Nebbia no período.

\subsection{Verdade e prática artística}

Um dos lados do primeiro single de Manal, publicado em 1968, é a composição "Qué pena me das", que consideramos outro ponto de condensação da confluência de objetos, traços de pessoa e cenográficos que estamos expondo. Como primeira apresentação em gravação que foi do trio, o disco, que do outro lado continha "Para ser un hombre más", deixava muito claro o fato de pertencer a algo completamente diferente da música "para jovens" dos programas de rádio e TV. Nenhum parentesco, sequer melódico ou de arranjos, com o "bailable” (parentesco que subsistirá em "Los Gatos” ao longo de toda sua trajetória). Em "Qué pena me das", longos fragmentos instrumentais, com interrupções e retomadas convocavam uma escuta mais complexa e predisposta à "música para escutar".

A voz de Javier Martínez neste rock também interpela um "tu", que é posto em cena de modo claramente disfórico a partir do próprio título. Como em "De nada sirve", o movimento de escapar de si é algo rejeitado, além de ser inútil. O que "dá pena" é essa constante tentativa de fugir e, na conclusão dos últimos versos, a predição de que "jamás 
te sentirás dentro de ti”. Não há um movimento explicitamente recomendado ou proposto, mas o sentir-se dentro de si levaria a um modo diferente de se perceber no "cosmos".

Nesta composição, ainda, se manifesta um complexo de representações que acompanhará desigualmente todo o desenvolvimento da configuração que vemos como dominante nesta etapa do rock argentino. Ele se relaciona com o que diversos estudos sobre o rock nacional têm caracterizado como a valorização da "autenticidade" e que aqui observaremos não nessa dimensão axiológica, mas no funcionamento discursivo que dá lugar a essa percepção, o que nos permitirá um acesso a aspectos contraditórios da discursividade no campo. E, para tanto, "Qué pena me das” não é apenas a primeira de que nos ocuparemos, é uma peça modelar que permite antecipar o que será visto em outras.

"Fingir”, “enganar”, “tergiversar” são, nesta composição de Martínez, denominações para os comportamentos que se afastam do necessário distanciamentoredirecionamento para si. Esses termos estão postos na mesma série do movimento de escapar, que, como vemos do início desta explicação, impede a crise e ruptura propugnada. Como seu oposto, aparece o termo "verdad". E a sintaxe não apenas contrapõe a "verdade" com os nomes do fingimento, também a relaciona ao próprio ser, daí a importância crucial para nossa explicação. Com efeito, primeiramente, na segunda estrofe, "él" é reformulado como "la verdad de su existir": E a terceira estrofe se encerra com este paralelismo:

Nunca eres tú, siempre es una ficción.

Nunca es verdad, solo cambias el actor.

Cremos que esse modo de representar discursivamente o "verdadeiro" guarda uma inocultável contradição. Em um discurso que proclama a busca de uma crise transformadora, aparece um forte apego ao representado como "verificável" que, como veremos, em não poucas composições é extensivo ao "real". À vez que se constroem topografias nas quais o deslocamento é necessário e se rejeita um mundo "triste", "podrido", “abandonado" e opressor, a fuga do "real”, ou quanto menos de uma dimensão do real, é condenada. Embora entrar na "verdadeira" vida suponha uma transformação integral, a não percepção ou o "escape" da vida "presente" é disfórico. A contradição poderia explicar-se levando em conta que o "verdadeiro" e "real" a ser reconhecido é 
principalmente o próprio ser. Com efeito, o "não escapar" parece ser o encontro crítico com esse ser, em solidão absoluta. Se revisarmos as recomendações do enunciador em "De nada sirve", tem que se chegar ao silêncio total, à completa falta de estímulos exteriores (inclusive não ouvir rock) para atingir essa solidão procurada. Também em "Porque hoy nací", a primeira composição que referimos nesta explicação, a tomada de consciência da própria solidão é um dos sintomas de que se chegou ao momento de transformação. No entanto, como veremos ao longo deste capítulo e do trabalho todo, a observação do conjunto do corpus mostra que essa relação entre "passagem por si" e "verdade / realidade" é instável e dá lugar a construções contraditórias para alguns objetos de discurso tais como o sonho ou o delírio. Uma das maiores contradições nesse plano é a que se dá em torno de um objeto central para analisar a discursividade em qualquer campo que envolva a procura estética: como se representa a prática artística, que é como observar qual é a metalinguagem do campo sobre si. Neste trabalho a consideraremos em sentido amplo: não apenas as formulações sobre o "fazer rock", mas todas aquelas sobre o fazer artístico ou artesanal de modo geral.

Voltando à composição de Manal que estamos analisando, e em especial ao paralelismo que citamos parágrafos atrás, observe-se que o fingimento e a mentira estão reformulados como "ficción" e "actor", bem como na estrofe anterior apareceram "disfraces" e "una historieta ${ }^{33}$ paralela de tu ser" também para opor-se ao "verdadeiro". A alusão a essas modalidades criativas pode ser vista como uma figuração sobre o engano e a falsidade, nutrida por metáforas que já circulam no dia a dia ("cuento", "verso", etc.), e provavelmente seja assim neste caso. No entanto, em "De nada sirve", a alusão às práticas artísticas, sobretudo as musicais, é direta, não metafórica. E não se limita ao fragmento referível aos músicos "comerciais", "han grabado treinta mil discos, han sido famosos, han firmado autógrafos". Também se questiona a utilidade de "tocar la batería" e das "guitarritas" (diminutivo muito empregado no discurso pejorativo sobre próprio rock), e se afirma o engano de "los que hacen música" que acreditam que esse fazer é o mais "importante". Mesmo essas práticas nas quais se desenvolve, de fato, o próprio dizer que escutamos (o de um cantor com sua "guitarrita"), são inúteis se direcionadas a “escapar de si”. Diferentes modos de apresentar a produção artística em relação à série do "verdadeiro" serão retomados em diversos pontos deste trabalho, mas vale antecipar

\footnotetext{
${ }^{33}$ No espanhol da Argentina, "historieta" é a denominação mais usual para a história em quadrinhos, mas também é um termo que pode ganhar um valor pejorativo para designar um relato não confiável.
} 
um exemplo em que, diferentemente desses que estamos vendo, o fazer criativo aparece na perspectiva eufórica do enunciador. Não casualmente, relacionado à observação de si. Em "Una casa con diez pinos", outro clássico de Manal, ouvimos "Prefiero sonreír, mirar dentro de mí, fumar o dibujar".

\section{5. A cronografia do amanhecer}

Voltaremos agora sobre a representação da mudança como "novo dia" e o lugar do amanhecer e do sol nessa figuração. Há três composições do período, uma de Manal, uma de Moris e outra de Miguel Abuelo, nas quais a figuração aparece com notável coincidência inclusive na forma linguística. Essas três composições estão dentro das que a historiografia do rock argentino classifica como "de naufrágio", segundo o valor que, como explicamos ao tratar de "La balsa" e "Billy el náufrago", adquire essa série de significantes para os pioneiros do movimento.

"Informe de un día", de Manal (autoria de Javier Martínez) inicia anunciando "Algo comienza hoy para mí". Esse "algo", que começa descrito como simples ("ginebra, amigos y nada más") vai ganhando relevância, é qualificado como muito esperado e capaz de mudar o ânimo, passar do pranto ao riso e à tranquilidade. A figuração do novo dia se apresenta da seguinte maneira: "El amanecer que ahora me espera es garantia de mi fe". Vimos em 1.3 que em "Requiem para un hombre feliz", de Los Gatos, o sol podia sair para cada ser. Aqui, em distribuição análoga, o amanhecer espera pelo ser.

"Muchacho", de Moris, não conta um dia excepcional, a cronografia tende mais ao cíclico. Um locutor interpela a um "tu”, o "muchacho", mas, no caso, com notável empatia e atribuindo-lhe um lugar de saber. O início de cada estrofe é "Muchacho, pronto amanecerá", leitmotiv que se repete também no final da gravação. Na terceira estrofe, é seguido por "el día no espera a nadie y crece como un niño hasta el atardecer". A mudança que se anuncia -como já antecipamos, cíclica- é que o verão está chegando, e com ele o "muchacho" recuperará uma vida de noites na esquina. Vários momentos dessa música entram em relação de paráfrase com outras composições do período ou posteriores. "Las noches serán tuyas", com "las mañanas y las tardes eran mías" en "El oso", do próprio Moris Destacamos essa imagem não apenas por essa ressonância, mas porque, dentro da 
composição, ela se articula com outras na construção de uma confluência entre tempo, espaço e ser, que faria parte da crise / mudança que traz esse "verdadeiro" viver como "sair" (não escapar). A segunda estrofe é fundamental nesse sentido. O verão, entidade temporal, está escondido “detrás de algún edifício". A casa está dormida e "não sabe” das noites que o "muchacho" vive na esquina, que é um lugar da geografia urbana mas, por ser de encontro, é também um tempo (no caso, o decorrer da noite). Na terceira estrofe, a vida nas esquinas reaparece com a especificação de que "sólo tú la conoces", que coloca o "tu" num lugar de saber compartilhável por quem possa incluir-se na restrição que a canção estabelece recortando um modelo.

Difícil não estabelecer, ao escutar que "sólo tú conoces" a vida na rua, outra relação parafrástica para esta música de Moris, desta vez com uma composição bem posterior: "Niño condenado", de Luis Alberto Spinetta. Conhecida também como "Perdonado", e gravada por primeira vez em 1976, no disco El jardín de los presentes, da banda Invisible, a música é claramente localizável no que, nos capítulos VIII a X denominaremos como "consternação" no rock argentino. Como em "Muchaho", também em "Niño condenado" a voz interpela um "tu" posto em cena com empatia e que perambula pela rua, mas tanto o dizer quanto a configuração de tempo e espaço distam muito do deslocamento gozoso e fundante que descrevem e propiciam as rupturas no primeiro rock nacional. A devastação já atuou e a intempérie protetora é agora desamparo: "Habla conmigo, perro de la lluvia. Habla conmigo, sólo tú conoces la vendimia de la calle. La delicia”. Não há inocência nem novo nascimento, como não há um novo dia. O "viejo perro / niño condenado / perdonado" está em quebranto e deve cuidar-se dos amos, que não descansam. Ao entonar "la delicia", irrompem violentamente cordas eléctricas e percussão, interrompendo o suave ponteio que acompanhava uma voz calma, que vira grito repetido e desgarrado. Delícia que consola mas lembra da dor, na época mais lobrega do rock nacional.

Além de "Informe de un día" e "Muchacho" ${ }^{34}$, a terceira composição que participa dessa confluência quanto à representação da mudança como "novo dia" e o papel transformador outorgado ao sol é "Hoy seremos campesinos", de Miguel Abuelo. Nessa música, um fragmento sobressai particularmente, porque a voz abandona o canto e passa a recitar: "La mañana de sorpresa nos tomó. Pero el sol corrió ligero y nos ganó". A

\footnotetext{
${ }^{34}$ Voltaremos sobre essas duas composições no Capítulo VI, ao tratar sobre outro aspecto da enunciação.
} 
recitação, frequente no folclore argentino e, em menor medida, no tango, é, como explicam Carnicer e Diaz (2002, 4-6), um dos traços que caracterizam a notável singularidade de Miguel Abuelo dentre os pioneiros do rock argentino, e era praticamente inexistente na época ${ }^{35}$. Antes do recitado, na descrição do dia apontado como "hoy" desde o título já encontramos que, como em "Porque hoy nací", de Manal, "el sol quema". Também a preferência por não estar dormido relaciona ambas as músicas. Trazemos à tona esta composição do Abuelo em função das relações parafrásticas com as duas que acabamos de comentar e com o conjunto da série que estamos mostrando. Porém, cremos que este é o momento adequado para, a partir da observação desta música, referirmo-nos a um conjunto de peculiaridades que aparecem na obra de Miguel Abuelo neste período y que estão diretamente relacionadas a temáticas gerais desta seção.

Em "Hoy seremos campesinos" se apresenta uma primeira pessoa que se dirige a um "tu" ("amigo mío") que o acompanha em parte de seu percurso. Porém, não é de início que os dois interlocutores aparecem representados. O canto começa com uma referência à criação verbal e ficcional, "son fragmentos, viejos cuentos de momentos que vienen y van”. É a partir dessa introdução que emergem, simultaneamente, o eu locutor e seu percurso de deslocamento: "He salido de paseo por un mundo que ha quedado atrás". Não apenas há uma reivindicação da prática poética, retomada na última estrofe com a referência aos trovadores, como é uma das pouquíssimas composições do rock desse período em que o passado cultural (embora impreciso) aparece como partícipe no processo de deslocamento e ruptura.

A incitação ao amigo, que ocupa o refrão, é, em primeiro lugar, a contar um conto. Ser "campesinos" não tem a ver aqui com um habitat nem menos ainda com uma estratificação social, mas com estar ao sol. Esse esplendor do sol queimando é a única referência espacial, já que há também um mundo, mas "há quedado atrás". O resto é som (canto e palavras) e corpos sobre os quais o canto pode deitar uma manta. A própria dicção da palavra "campesinos" sugere um estatuto especial, de algo que deve ser deslocado das significações costumeiras. A palavra é decomposta em ecos, o canto é interrompido para dar lugar a sua aparição. Destacamos que nesta composição, a fruição de ficções e de artifícios é posta como parte do processo de transformação buscado, diferentemente do matiz de falsidade ou de engano com que, como vimos a partir de "Qué pena me das", de

${ }^{35}$ Como vimos no Capítulo III, encontramos um caso na obra de Pajarito Zaguri, e é o único que conhecemos. 
Manal, aparece valorizada em boa parte da produção do nascente rock nacional quando não é parte do encontro "consigo". Em função desse lugar diferente para a produção artística, examinaremos a seguir outros aspectos da obra primeira desse compositor.

\subsection{Solo y nada más}

Miguel Abuelo era o pseudônimo de Miguel Angel Peralta, um dos iniciadores do progressivo, que morreu prematuramente em 1986 como vítima do HIV. Na primeira época teve uma produção não muito numerosa, mas significativa pela sua originalidade, dada, segundo Carnicer e Díaz, (2002), pela marcada heterogeneidade de elementos e procedências posta em jogo nas composições. No que diz respeito da configuração enunciativa dominante que estamos analisando, cremos que a obra primeira de Miguel Abuelo à vez que participa fortemente da sua formação, mostra algumas diferenças que vale a pena considerar.

Comecemos por reconhecer o muito que há em comum. Abuelo é, junto com Spinetta, o compositor em que mais se nota o tom prescritivo que, como aponta Colomba (2010) e nós concordamos, emerge com insistência em diversas músicas da primeira época. Por outra parte, como nas composições que já observamos de Javier Martínez, Nebbia ou Moris, bem como em boa parte do que ainda veremos de outros autores, o deslocamento é condição necessária para a mudança procurada. Em "Mariposas de madera" escutamos que "ya es hora de caminar", em "Oye niño" que "todo lo que ata es asesino" e, em "Hoy seremos campesinos", como acabamos de ver, o próprio locutor é introduzido junto com ao relato de ter feito um "paseo por un mundo que ha quedado atrás". Como em Moris ou em Manal, é reivindicado um "sair”. Em “Oye niño”, inclusive, como em "Porque hoy nací", há um desprendimento do nome, e, analogamente a "De nada sirve", onde o "eu" propõe despojar-se de estímulos, bens e produtos, aqui a ordem é jogar fora a "armadura" que protege, processo que culmina em fazer a cabeça explodir: "haz tu cabeza estallar". Concordamos com Carnicer e Díaz em que "se trata de una metáfora típicamente rockera que reclama un acto de liberación" (2002, p 8), e o desenvolvimento histórico posterior do rock argentino contém muitas figurações do tipo. 
Porém, cremos que, na imagem de "Haz tu cabeza estallar", é atingido um ponto mais radical do processo de mudança / ruptura. O ser conserva centralidade, já que é ele próprio que provoca o "estallido". Mas na sequência linear do canto, o resultado não é um encontro com algo de si ainda não visível, nem uma transformação: a música termina ali. O que resta depois da cabeça explodida, a que representação do ser dá lugar essa liberação?

Outra música do Abuelo da mesma época, "Pipo la serpiente", também gravada como "Estoy aqui parado, sentado y acostado", composta em parceria com Pipo Lernoud, focaliza precisamente um estado posterior à mudança. A letra é uma longa descrição em primeira pessoa, com predomínio de construções resultativas como a que aparece no início: "Ya he perdido el olor de los duraznos". A voz afirma ter mudado de pele, de cor, estar desprendido do tempo e do espaço por onde circula, e até ser, hoje, "outro". Dois versos na segunda parte formam um paralelismo que é o único fragmento apresentado em um pretérito sem vínculo com o presente e parecem indicar o momento de passagem: "Yo estuve muy solo, pero solo sin recuerdos. / Yo estuve muy solo pero solo y nada más". Solidão pura, como a "solidão interna" da qual "De nada sirve" propõe não fugir. Cambiasso (2013, p 74), apesar de escutar na interpretação do Abuelo um tom mais desgarrado que o que nós apreciamos, e de fazer, portanto, uma leitura mais angustiosa, também vê, nessa letra, a solidão expressada como imperativo. Cremos que a partir desse "solo y nada más" podemos ver essa crise como a separação de toda circunstância, que na estrofe que lhe segue se reafirma e desenvolve como ausência de memória, de linguagem:

Las cosas que yo veo son cosas sin historias, sin tiempo y sin memoria, son cosas nada más. Me acerco a una piedra y la miro sin pensarla, la toco sin nombrarla, la toco y nada más. ${ }^{36}$

Se esse modo de focalizar o ser na mudança perseguida constitui, em Miguel Abuelo, apenas uma diferença de grau no mesmo caminho de regularização que

\footnotetext{
${ }^{36}$ Os acréscimos feitos por Miguel Abuelo na regravação dessa música em 1975, no disco Miguel Abuelo et nada, publicado na França, aprofundam mais esse caráter "absoluto" do ser: "No tengo nombre, no tengo amigos, no tengo lenguaje, no tengo verdad."
} 
predomina no campo, outro aspecto da configuração mostra, diferentemente, um embrião do que poderia ter sido uma distância em relação a esse predomínio. Há, nas obras desse compositor no período estudado, uma leve desestabilização da delimitação de vozes e de personagens, relativamente mais rígida no conjunto do campo.

Em parte, isso se relaciona com o lugar dado às "ficções". Já vimos que "Hoy seremos campesinos" está completamente construída como celebração da criação de relatos. No plano das vozes representadas, isso é concomitante com uma delimitação relativamente incerta, que superpõe, inclusive, tempos: "Son fragmentos, viejos cuentos, de momentos que vienen y van". Nesse rumor incerto irá confundir-se a voz do "amigo" a quem pede contar um conto. E, na segunda parte da canção, junto aos "trovadores" de outros tempos, "alguém" canta. Por sua parte, em "Mariposas de madera", como bem observam Carnicer e Díaz (2002, p 6), as figurações construídas (borboletas de madeira ou de asas d’água) não poderiam voar e, cremos nós, aparecem como modos de aproximação de um "tu" procurado e fugidio. Outro momento de desafio à estabilidade das vozes representadas se apresenta em "Oye niño", contraditoriamente, a mais proverbial e preceptiva dessas canções. Na sua primeira e mais conhecida gravação no single da gravadora Mandioca, em 1968, o verso "No hay caminho hasta tu suerte" é seguido por "Nadie te puede ayudar". Mas em gravações posteriores ao vivo, o verso é substituído por "Ni es del cantor el cantar".

Reconhecidas estas diferenças, que podemos também relacionar a aspectos da singularidade de Miguel Angel Peralta visíveis nos seus modos de interpretar ao vivo, passaremos para uma composição de Tanguito que também nos interessa no que diz respeito à prática artística. Foi divulgada como "El despertar de um refugio atómico", apesar de que, no início da gravação em estúdio, única que se conhece, o cantor a apresenta apenas como "El despertar" ${ }^{37}$. A referência ao "refúgio atômico" no nome motivou leituras, das quais discordamos completamente ${ }^{38}$, que a incluem entre as várias músicas que Tanguito compôs, sozinho ou em parceria com Moris, de denúncia

\footnotetext{
37 O disco publicado por Talent em, 1973 com o nome Tango compila gravações efetuadas em 1970, em um período em que José Alberto Iglesias já estava em franco deterioro. A publicação foi póstuma, já que Iglesias, como já informamos, morreu em 1972. Para a edição, os produtores deixaram alguns dos diálogos prévios à execução de cada música. No caso da que estamos comentando, o cantor diz literalmente "voy a hacer la de las primeras, El Despertar."

${ }^{38}$ Por exemplo, a de Diez Olea (2007, p 82).
} 
antibélica. Cremos que se trata de um nítido exemplar de "naufrágio" como perambular urbano, na linha que já explicamos na abordagem de outras composições nesta seção.

A musicalidade lembra um blues, o canto de Tanguito na gravação, acompanhado apenas pelo violão, lembra por momentos o estilo de Javier Martínez. Mas as sílabas se repetem trêmulas, suas vogais se prolongam, desfazendo o significante e aproximando-se de um cantarolar. Inclusive, no final do que poderíamos considerar a segunda estrofe, na metade da canção, o cantor diz "tres puntos suspensivos" ("reticências"), como representando, na própria metalinguagem, as prolongações de sílabas.

$\mathrm{Na}$ letra, o locutor fala principalmente de si, com uma breve alusão a "otros dormidos". De início, como em "La balsa", aparece um desejo de deslocamento, "Solo quiero viajar". Diferentemente da voz naquela outra música, que anunciava ir "al lugar que yo más quiera" e punha como destino "la locura", diferente do "Muchacho" de Moris e das vozes deflagradas por Miguel Abuelo e por Manal, este carece de saber, não sabe onde ir. E a topografia de seu deslocamento será o próprio sonho. Sonhando acordado chegará ao encontro consigo.

Na estrofe final, o sonho é representado como estrada ("la ruta de mis sueños"), e se reafirma a passagem por si: "comenzaré a hacer uso de mi dedo / de mi idea". A imagem de "hacer uso de mi dedo" pode remeter a pedir carona na estrada (no espanhol rio-pratense, "hacer dedo"), e também ao ponteio no violão, em mais uma imagem em que a própria prática musical é posta como elemento partícipe da mudança, e mais uma vez, como já vimos em "Una casa con diez pinos", de Manal, tem esse papel por ser caminho para o encontro do ser consigo. E, mesmo considerando a figuração da carona, que, como tal, requer necessariamente dos outros, a sequência reformulatória “de mi dedo / de mi idea" acaba também fechando o círculo na perspectiva do mesmo.

\subsection{Al fin mi duende se abrió}

Outro despertar como mudança, que introduz uma variação rica e complexa nesta configuração, é o que se canta em "Final", de Almendra, de autoria de Luis Alberto Spinetta, que apareceu no terceiro single da banda, em 1969, logo junto com o lançamento do primeiro LP, sobre o qual trataremos no capítulo seguinte. Comecemos por apontar 
uma caraterística temática desta música que, embora não seja nosso foco neste trabalho, não podemos deixar de reconhecer. "Final" condensa nitidamente um modo de representar a relação com a cidade, e de contrapor a cidade com a natureza, que é próprio do rock argentino dessa época e de períodos posteriores, e que é amplamente tratado, por exemplo, em Díaz (2005, p 100-105). A cidade como espaço de solidão, artificialidade e opressão, muitas vezes sintetizado na cor cinza (como vemos em "Final": "yo también me dormí detrás de la gran ciudad vestido de gris"), mas também como espaço ao qual se reconhece pertencer. Concordamos a respeito com Toscano e Warley $(2003,115)$ na observação de que, nesse aspecto, o rock argentino participa de um discurso que remonta ao romantismo e depois às vanguardas, e que tem pela cidade grande uma relação dupla de atração e rejeição. Outras composições que já abordamos nesta seção se orientam para um ou outro desses dois polos (respectivamente, por exemplo, "Muchacho" e "Una casa con diez pinos"), mas, como já explicamos, não se trata de um tópico de interesse específico para este trabalho, só vamos abordá-lo tangencialmente e em função do tratamento dos nossos objetivos em cada seção.

Em "Final", a cidade grande é o espaço onde se situa a voz que se apresenta na primeira pessoa, mas também um espaço a ser superado para que se desenvolva um acontecimento transformador, que consideramos na série de "deslocamentos" que estamos abordando e analisando. Não se trata aqui exatamente de um renascer, mas sim de uma mudança desejada, relacionada com o madrugar depois de dormir, e representada em paralelo por um processo criativo que mostra o que podemos ver como uma variante peculiar da passagem do ser por si, marcada pela idiossincrasia da poética de Spinetta e das leituras orientalistas que o influenciaram e que mencionaremos em 2.1.

Comecemos por diferenciar, na materialidade sonora da gravação que circulou, a presença de elementos extramusicais que não aconteciam nas apresentações ao vivo. No início, assobios de pássaros acompanham a bateria, e cessam quando a guitarra dá início. No final, a bateria vai se fundindo com um som que parece o dos carrosséis característicos das praças das cidades argentinas, e a localização em um desses exteriores urbanos é reforçada porque se escuta alguém que pergunta “¿A dónde vas?”. Tanto o carrossel quanto a sugestão sonora do espaço de brinquedos de uma praça se acrescentam às outras remissões ao universo infantil que veremos na música.

A invocação que inicia o canto tem nitidamente o ser como centro de direcionamento para o entorno, "grillos, plantas, vengan hacia mí", perspectiva que se 
a "verdade" se aplica àquilo que participa da mudança crítica e do distanciamento e aproximação do ser em direção a si mesmo. O que é nitidamente diferente é o papel dado à criação e à ficcionalização, que se aproxima do que vimos em Miguel Abuelo, já que essa prática é vista como caminho para a transformação e para o reencontro consigo.

Esse reencontro tem aqui a particularidade de que consiste em um desdobramento do ser em criador e criado, e, na cenografia posta, apresentador e apresentado. "Hoy habrá función", em paralelo com "fue piel al fin" na estruturação melódica e verbal dad duas partes, é uma formulação que instaura um locutor próprio dos espaços pré-midiáticos do espetáculo popular, da convocação a algum tipo de apresentação ambulante, que bem poderia localizar-se no âmbito de praça urbana sugerido pelo som do "organito" no final da gravação. E o apresentado, o arlequim, fará sua dança sobre o sol, também aqui relacionado à novidade.

O encontro consigo a partir de outro ser, depreendido do mesmo ou concebido por ele, aparece em várias produções de Spinetta na época. Em "Canción para los días de la vida”, composição gravada só em 1977, mas composta em torno de 1969, a entidade representada pela primeira pessoa também se encontra em um instante crucial de mudança, enunciado mediante a denominação "este día", que aparece no início de cada uma das duas partes, com uma saliência análoga ao "hoy" na composição de Javier Martínez com que demos início ao percurso deste capítulo. Também nesta composição, o sol, na segunda parte, marca a consumação da mudança. Ao longo da canção sobressaem imagens do ser em uma centralidade absoluta em relação ao seu entorno e/ou como alvo do seu próprio movimento ou da sua própria percepção: "voy a ver si puedo correr com la mañana silbándome en la espalda, o mirarme em las burbujas", "si la lluvia llega hasta aqui", "los relojes harán que cante", "y la espuma gira em torno a mi piel, me han puesto manos para hablarle a las cosas de mí", "me pondré las ramas de este sol que me espera para usarme como al aire".

E há, na canção, gravada inteiramente com violão acústico, dois momentos, no final de cada uma das duas partes, que se diferenciam tanto na música quanto na letra. São os que correspondem ao advento de um novo ser, e se iniciam respectivamente com "al fin mi duende nació" e "al fin mi duende se abrió". Nesses fragmentos, a melodia é diferente do resto da canção, tornando-se mais simples, e o canto se aproxima de uma canção infantil ou até de ninar. Na letra, o foco sai completamente desse locutorpersonagem recortado com tanta omnipresença. E as duas descrições do "duende" que ali 
se produzem estão, do nosso ponto de vista, entre as passagens mais singulares e ricas da poética do rock argentino. Traços pontuais -orelhas, nariz, cabelo e coração- que poderiam compor um desenho ou um boneco, já que combinam elementos heterogêneos como um cogumelo, toalha de mesa, roupão. O "duende" tem um violino e depois ele é o próprio violino. Ele é o feito e o próprio fazer: "siempre canta", "nunca calla", "nunca se adormece”. Apesar de sua condição "posterior" e sua meninice de duende guardado por gnomos, tem algo em comum com o ser autocentrado e automagnificado do qual nasceu: "solo se desprende". E os conecta um gesto "un guiño al ver que todo es verdad", verdade que, também aqui como nas letras de Moris e de Manal, é qualidade do percurso em direção ao si mesmo "renovado".

"Canción para los días de la vida" foi pensada como parte de um projeto de ópera (Berti, 2014) que Almendra concebeu antes da sua separação, e não chegou a realizar. Vale a pena deter-se em uma descrição que Luis Alberto Spinetta realizava em 1970, publicada originalmente na revista Pinap de abril daquele ano, e que aqui reproduzimos de Berti (2014, p 54):

\section{Primer acto:}

Un mago de agua llega a una ciudad -cualquiera- con una meta bien definida: la búsqueda de la pureza. En su tránsito por la ciudad se encuentra con un niño y le pregunta qué puede hacer para conseguir su cometido. El niño le indica que debe hallar cinco trovadores que, simbólicamente, serán (por orden): Litto Nebbia, Moris, Tango (Ramsés), Javier Martínez y Roque Narvaja; y el sexto, que está loco, caracterizado por Miguel Abuelo. El último trovador -el loco- es quien por fin le va a sugerir la clave para su búsqueda. Luego de peregrinar por las calles de la ciudad encuentra a cada uno de los cinco trovadores, y finalmente al loco, quien le dice que debe esperar a que los árboles le pidan tres deseos. $\mathrm{El}$ mago de agua no comprende, pero espera. $\mathrm{Al}$ fin, los árboles le piden tres deseos, y el último -el más importante- es que el mago se duerma. El mago, ya en profundo sueño, encuentra al mundo, que se llama José. El mundo -José- le hace una suerte de conjuración, donde lo atormenta con todas las cosas que aquel jamás podrá entender (ambición, odios, guerras y todas las injusticias de la humanidad) y lo condena a alejarse de su dimensión de mago, y a despertar del sueño bajo la forma de un hombre de carne y hueso, que es un ciruja. Finaliza el primer acto con el mago dormido.

Segundo acto:

Al despertar el mago de su profundo sueño en forma de hombre -de ciruja- debe retroceder siete días de su vida para encontrar a alguien, a quien sabe que debe mirar hasta el fin. El encuentro de estos dos seres -que simboliza el encuentro del hombre consigo mismo, pues son una misma persona- se debe producir en el infinito, y el abismo que separa al hombre desde su raciocinio hasta lo irracional, lo inaccesible, está representado por la muerte física. (Una vez terminada la ópera, se alzará en canto universal una conocida adherencia musical). 
O mago tem como meta "la búsqueda de la pureza". E a busca finaliza no encontro consigo mesmo. Para além das diferenças de cenário, de objetos, de tom, é um processo análogo ao alcance da solidão absoluta, o "solo y nada más" de Miguel Abuelo, a "soledad interna" de Moris, o "solo" que faz tomar consciência de "não ser" em Javier Martínez, consciência necessária para despertar, sair, fazer a cabeça "estallar". Como nas propostas desses outros compositores, despojar-se de tudo é um dos traços que determinam esse estado que permite a crise transformadora. No caso, o despojamento é dado pela figura do "ciruja"40 em que se torna o mago ao virar homem. E a passagem é um dormir e um acordar. Alguns traços da relação ser/entorno que vemos como relativamente regulares na configuração dominante no rock argentino se exacerbam neste relato de Spinetta, tanto como em "Canción para los días de la vida" e, como veremos no capítulo seguinte, na composição do encarte do primeiro disco de Almendra. No seu próprio sonho o mago encontra nada menos que "o mundo". E o "si mesmo" que vai encontrar finalmente é alguém que ele vai ter que olhar pela eternidade, e no infinito.

É interessante observar a distribuição dos outros músicos aludidos no relato. Dos seis "trovadores", os quatro primeiros "por orden" são as vozes mais representativas e conhecidas do rock nacional na época, inclusive, de modo geral, na sua "ordem" cronológica de aparição na cena musical. Pelo menos no plano do projeto, Spinetta desloca o mais saliente do movimento para sua peça imaginada. Apenas desentoa, de modo inexplicável, a inclusão de Roque Narvaja, na época líder de La Joven Guardia, banda que, se teve um começo nos limites incertos entre o nascente campo do rock e a música "beat" comercial, em 1970 seu rumo nessa segunda direção já se mostrava bem nítido. E não nos parece casual o lugar especial dado a Miguel Abuelo como o último trovador, logo aquele que acerta no caminho a seguir. Na história narrada, ele ocupará o papel do "louco" que, precisamente, serve de guia eficaz para o objetivo do mago. Há, nessa época, algumas semelhanças importantes entre Spinetta e o Abuelo, além da que já apontamos sobre o tom prescritivo. Ambos são os mais experimentais dentro do novo movimento. Ambos se valem de uma grande heterogeneidade de recursos e procedências musicais, embora Miguel tenha avançado mais na combinação de linguagens (recitado, performance próxima do music hall, etc.). E as figurações nas letras dos dois são de maior

\footnotetext{
${ }^{40}$ O termo "ciruja", no espanhol argentino, denomina um catador de lixo ou, de modo geral, um maltrapilho.
} 
elaboração que as do resto dos compositores, com recurso, em ambos, a repertórios do conto maravilhoso e de diversos acervos místicos, bem como combinações originalíssimas $^{41}$. As "mariposas de madera" e de "alas de agua" de Miguel Abuelo bem podem coexistir com os "gnomos de lata", o "hongo como nariz", e com os "ojos de papel”, "piel de rayón” ou "corazón de tiza" das letras de Luis Alberto ${ }^{42}$.

\subsection{Recapitulando}

A última composição que observaremos neste primeiro percurso pelo processo de regularização que estamos analisando é do primeiro disco da banda Pappo's Blues, liderada por Norberto "Pappo" Napolitano depois de que deixou Los Gatos. Essa banda mostrou claramente o projeto de Pappo, centrado no virtuosismo na guitarra elétrica. Os blues e peças pesadas dos vários discos da banda mostram, de modo geral, um forte trabalho instrumental e pouca consistência nas letras, que evidentemente não eram uma preocupação central para Pappo. Mesmo assim, há particularidades que se detectam na dimensão verbal das músicas e que, curiosamente, também se observam em bandas posteriores, das décadas de 80 e 90, influenciadas pelo projeto de Pappo ou que participam da parcela do campo que, dentro do rock argentino, tem no "Carpo" 43 uma autoridade. Uma dessas peculiaridades é o emprego recorrente do hipérbaton

A primeira música desse disco gravado em 1971 se denominou "Algo há cambiado". Como várias das que vimos neste percurso, trata, já a partir do próprio título, de uma mudança crítica. Uma primeira pessoa se apresenta rogando que o deixem para não enlouquecer, e afirma "no soy quién para ser todo lo que soy". Diz que alguma coisa mudou "dentro de mí", e que por isso quer viver "alucinado". A última estrofe anuncia um renascer no qual, de certa maneira, há também a "direção para si”, e também aqui, o

\footnotetext{
${ }^{41}$ Díaz (2005, p 108) vê em ambos uma "reivindicación de lo 'irreal' y lo 'fantástico"”. Concordamos no que se refere ao maravilhoso, mas sem perder de vista a contradição que em ambos, como nos outros compositores, se percebe quanto à concomitante exaltação do "verdadeiro". Parece-nos, de qualquer modo, um dato importante que Díaz, em um livro em que trata do conjunto da produção do campo, encontre essa peculiaridade nos dois músicos e não no resto.

${ }^{42}$ Cambiasso (2013, p 173) informa que Spinetta teria dito que "Almendra no habría existido si no hubiese escuchado 'Mariposas de madera'".

43 "El Carpo" é um dos apelidos de Napolitano, falecido em 2005 em um acidente de moto.
} 
sol participa da cena de mudança: "Voy a ver nacer el sol / en medio del camino / y también voy a nacer / de acuerdo a mi destino".

Apresentamos, nesta seção, o que nos parecem saliências muito representativas, no corpus do primeiro rock nacional, da configuração de instâncias de pessoa, cenografia e objetos de discurso que nos parece que alcançou domínio e centralidade no surgimento do campo, como também forte repetibilidade em etapas posteriores, inclusive em relação contraditória com configurações marcadamente diferentes. O pré-construído que nos parece embasar essa configuração é o de uma necessidade de mudança voltada para o mundo mas que passaria primeiramente pelo indivíduo. Sua manifestação, que denominamos como "saliência" é a encenação de um processo de mudança crítica, no ser, que envolve um distanciamento e redirecionamento para si, podendo atingir uma "pura solidão consigo" que questionar toda relação de significação com o entorno, inclusive o nome. O deslocamento, de caráter fundacional, inaugural, muitas vezes denominado como novo nascimento, é representado como ponto de partida também na dimensão temporal, pelo geral no que se representa como "hoje" ou como "o presente". O amanhecer, ou a presença do sol aparecem com frequência na figuração. Quando se alcança a dimensão narrativa, o processo pode ser visto também como um relato de aprendizagem. Assim, o representado como "verdade" e "verdadeiro" coincide imaginariamente com esse novo estado do ser, já dotado de um propósito, e não com o estado de coisas rejeitado.

\section{Procurando filiações}

Realizado este primeiro percurso pela materialidade de algumas composições, tentaremos agora propor relações entre as regularidades descritas e as condições de produção dadas pela circulação discursiva no campo cultural argentino da época, que veremos como uma arena específica de confronto. Embate entre tendências ideológicas que agiam em boa parte do mundo, mas que ganharam delimitações particulares no real sócio-histórico do país e que se associaram de formas específicas no linguístico afetado por esse real. É parte do nosso propósito, como antecipamos no Capítulo I, chegar a hipotetizar diversas posições de sujeito que atravessam o discurso no primeiro rock argentino, porém, cremos tão importante quanto isso balizar esse caminho relacionando 
o que vamos encontrando como regular e repetível na materialidade com o que a crítica cultural e a história das ideias na Argentina tem refletido sobre as visões de mundo e de sociedade que se confrontavam na época, inclusive lançando mão de documentos de outros movimentos culturais. Dessa reflexão e do retorno sobre os acontecimentos discursivos e suas condensações é que surgirão as hipóteses que possam dar lugar às sínteses que desejamos.

Nos três itens que seguem daremos os primeiros passos nesse sentido, que se continuarão nos capítulos VIII e IX, mas que de fato retomaremos ao longo da tese toda. Primeiramente, no item 2.1, daremos conta de possíveis relações entre as observações que fizemos até aqui e o que propõem estudos anteriores sobre o campo do rock argentino que, a partir de referenciais teóricos e metodológicos diferentes do nosso, atenderam também a aspectos da discursividade. Depois, em 2.2, abriremos a reflexão a estudos sobre as práticas culturais e o debate ideológico na cultura argentina da época. E finalmente, em 2.3, retomando o que observamos na materialidade do primeiro rock argentino, explicaremos como vemos a concorrência contraditória de visões, saberes e possíveis posições de sujeito no que tentamos caracterizar como regularização discursiva na primeira época do "progressivo".

\subsection{Dialogando com outros estudos}

Claudio Díaz (2005), abordou o rock argentino a partir de uma perspectiva sóciosemiótica. No que denomina como "universo de sentido" do rock argentino, desenvolve um trabalho de localização de tópicos mais ou menos recorrentes. Um desses tópicos apontados por Díaz, o da viagem e a travessia, se relaciona parcialmente com o que estamos analisando aqui. Com efeito, o deslocamento topográfico que observamos, nas seções anteriores deste capítulo, como ponto de partida da encenação da mudança crítica na configuração que estamos analisando, pode ser considerado na ordem de fenômenos a que se refere o autor:

Según lo expuesto hasta ahora podría decirse que el rock, en la Argentina, nace como un viaje; como una travesía desde un ámbito percibido negativamente, asfixiante, rutinario, sometido a la "Normalidad" y a la "Ley", hacia un mundo aludido de modo indirecto por el abandono y la transgresión, por la locura y el naufragio. (DÍAZ, 2005, p 105) 
Nessa linha de reflexão, em outro ponto do texto em que trata especificamente sobre Spinetta, Díaz propõe que a viagem e a travessia, bem como a figuração do voo, são articuladas em torno do problema do olhar: "una mirada diferente, una mirada que se sale de lo normal, y transgrede la regla, obtiene otra perspectiva y 've', por lo tanto, otra cosa" (2005, p 109). Nesse caminho de análise, afirma que "la construcción de una mirada 'otra' no es, sin embargo, una preocupación exclusiva de Spinetta, sino que aparece recurrentemente en distintas bandas y estéticas" (ídem, p 109). Para o autor, a particularidade de Spinetta seria que ele não direciona esse olhar para uma crítica do exterior (as relações, as instituições, os costumes), mas em direção para a interioridade, do encontro do ser com si mesmo. Díaz relaciona essa temática em Spinetta com as leituras que o músico realizou de Jung e, por meio dele, de tratados chineses sobre meditação. E conclui:

\begin{abstract}
Esa verdad que ensanche los límites de la conciencia, que carezca de dogmatismos y de hipocresías, que permita el encuentro con uno mismo y con los otros; esa búsqueda de una mirada "otra" que permita ir más allá de la superficie gris de la ciudad; ese planteo de una comunicación más auténtica basada en una mirada reflexiva sobre sí mismo, ese tipo de actitud era lo que estaba presente en los discos anteriores de Spinetta, y llega a ser dominante en el rock argentino. (DÍAZ, 2005, p 114, grifo nosso)
\end{abstract}

É bom apontar, então, as diferenças que vemos entre o que Díaz está observando nesse trabalho e o que nós temos explicado e continuaremos abordando nas próximas seções como "distanciamento e redirecionamento sobre si". Trata-se de processos em diferentes planos, embora possam se sobrepor em algumas das suas manifestações. Díaz está abordando "tópicos", que, podendo ser mais ou menos buscados pelos compositores, são necessariamente objetos de discurso, e não modalidades de enunciação, como as que nós indagamos. É como coisas ditas, como assunto do qual se trata, que Díaz localiza a viagem e inclusive o olhar sobre si mesmo. A construção, em termos do próprio Díaz, "programática" de um olhar outro que se direcione reflexivamente sobre si próprio pode ser uma das manifestações mais conscientes (não casualmente, Díaz a denomina como "actitud" no trecho que acabamos de transcrever), da regularização que estamos analisando. Mas tanto o direcionamento do ser sobre si quanto sua centralidade na cena em relação ao entorno acontecem, em quase todos os casos que vemos, não como 
"proposta" de uma voz mais audível entre as outras, nem apenas como assunto específico do qual trata a composição, mas como traço da própria configuração enunciativa. Ela tem um grau de repetibilidade e de incompletude que, na dimensão discursiva em que a estamos abordando, não pode ser atribuída apenas a uma "proposta", já que não necessariamente aprece como tal.

Em "Porque hoy nací", por exemplo, a direção para si se manifesta no processo descrito no início, "hoy adivino qué me pasa / por qué mi nombre no soy yo", e na sua relação com "hoy nací". Em "De nada sirve", como em "Ríete" ou "Qué pena me das", sua irrupção é pela negativa, pela rejeição ao ato de fugir de si. Em "Informe de un día" o amanhecer media entre as duas pontas do deslocamento; em "Pipo la serpiente", a direção para si é o isolamento do ser a respeito de toda circunstância. Pode também não ser assunto ou figuração central em uma composição e aparecer como elemento que adquire saliência pela sintaxe, como na enumeração que já referimos de "Uma casa com diez pinos" ("Prefiero sonreír, mirar dentro de mí, fumar o dibijar") ou na clivagem de "Informe de un día" ("El amanecer que ahora me espera es garantia de mi fé"). E, tanto nessas músicas quanto nas outras que fomos abordando nesta seção, há outros traços que se combinam de modo relativamente regular com esse direcionamento para si: ancoragem presente -como ponto de partida- da crise de mudança, correlação com um despertar ou nascimento ou com ambas as coisas, despojo de todo o exterior, inclusive dos estímulos ou das significações, envolvimento do nome ou de sua desaparição na mudança.

Concordamos com Díaz em que, em determinada época da produção de Spinetta, o encontro consigo corresponde a um programa explícito, e claramente relacionado com as leituras desse músico-poeta, relação que esse crítico explica com um aprofundamento e um manejo das referências e filiações incomum nas leituras sobre o compositor. Porém, pensamos que, como deslocamento na cenografia enunciativa, que é como nós o descrevemos, o distanciamento e redirecionamento do ser sobre si, que não necessariamente ganha a forma de "busca interior", é um traço regular na discursividade do rock argentino da época, traço que se integra com outros na formação de configurações enunciativas relativamente estáveis.

Outro estudioso com quem continuaremos dialogando neste ponto da nossa explicação é Diego Colomba (2010), que já referimos no Capítulo II em relação à renovação cultural na Argentina, e, no capítulo anterior, no que diz respeito ao melodramático. Já explicamos também que concordamos com ele a respeito da forte 
presença de um tom prescritivo no discurso inicial do rock da Argentina. Na sua tese, embora ele não aborde o discurso com o mesmo aparelho analítico do nosso trabalho, há reflexões muito pertinentes para estabelecer relações com a configuração enunciativa que estamos analisando. Explicando o modo como o rock argentino vai conformando uma temática própria no que diz respeito ao emocional e à esfera sentimental, o pesquisador propõe que as letras do que ele denomina como o primeiro período -aproximadamente até 1972- tentam uma "educación sentimental" porque "buscan la perfección de la individualidad: a través de la introspección, comparan, observan y analizan las vivencias, las respuestas íntimas a un hecho que perturba (datos, hechos, situaciones vividas, resguardadas) para extraer enseñanzas de las mismas." (COLOMBA, 2010, p 51) ${ }^{44}$.

Nesse processo de aprendizagem, a representação da solidão teria a ver com o que Colomba denomina como "sentimentos sentidos", diferentemente de "sentimentos vividos" (2010, p 51). Os sentimentos "sentidos" são os interiorizados, e, na coerência que ele encontra nas letras do período, é através deles, isto é, da introspeção, que se teria acesso a "una realidad más allá de la visión humana corriente" que pode ser explorada mediante "una autorrealización paradójica en el aislamiento" (p 52). Cremos que essa observação de Colomba é harmônica com o que observamos neste capítulo sobre o direcionamento do ser no percurso de mudança crítica, e com o que propomos no capítulo anterior sobre o amor como experiência auto-centrada e como exposição da potencialidade criativa do locutor-artista.

\subsection{As formas diversas do "humanocentrismo" e o papel do indivíduo.}

Passaremos agora a considerar as condições político-ideológicas, e a circulação discursiva, procurando relações com o desenvolvimento da regularização no discurso do novo campo que nele vai surgindo. Dada nossa opção teórica, esses fatores são vistos como parte das condições de produção, e devemos sempre considerá-los como mediados

\footnotetext{
${ }^{44}$ Só não concordamos, a esse respeito, com um aspecto da análise que o estudioso faz de "Porque hoy nací", de Manal. Ele lê a formulação "Porque estoy solo y no soy" como premissa sobre a necessidade de "sentir con los otros". Cremos, como já explicamos, que, nessa composição, a solidão aparece já como um aspecto necessário da introspeção "educativa" que o próprio Colomba ilustra na sua explicação, e que se relaciona com o processo de deslocamento e mudança que nós propomos nas seções anteriores deste capítulo. Veja-se, também, que em "Si no hablo de mí”, composição pouco posterior do mesmo Martínez que abordaremos no Capítulo VI, a solidão, na narração de uma mudança análoga, é claramente celebrada.
} 
tanto pelo dialogismo perceptível no corpus discursivo que analisamos quanto pelas séries discursivas históricas das quais participam os enunciados desse corpus. No Capítulo II, explicamos que o "progressivo" argentino aparece em um período de questionamentos, rupturas e tentativas de transformação nas práticas culturais e políticas. Como se desenvolve esse processo no embate ideológico no país? O que podemos encontrar nele que conduza para relações com as regularidades que estamos analisando?

Retomaremos aqui, primeiramente, reflexões produzidas no campo da história das ideias e que introduzimos no item 1 do Capítulo II. Oscar Terán (1991 e 2008) observava que durante a década de 50 começa, em lugares de forte capital simbólico do campo cultural da Argentina, um processo de renovação que vai se manifestar em diferentes espaços de práticas, confluindo com mudanças nos movimentos sociais e nas filiações políticas. A partir do campo intelectual, primeiramente no âmbito acadêmico, com os “denuncialistas"45, mas também na crítica artística e literária, consolidava-se, como mencionamos naquele capítulo, uma rejeição ao espiritualismo liberal, em prol de uma visão "corporalista y fuertemente historicizada" (1991, p. 20). A leitura do existencialismo sartriano, embora não fosse o único referente dessa corrente, é o que mais nitidamente a representa. E se Terán emprega reiteradamente o termo "humanocéntrico" é porque considera que, mesmo com a grande diversificação que esse pensamento vai alcançando até os anos 70, o que enlaça toda essa diversidade é um humanismo entendido como "la concepción moderna del sujeto como portador y árbitro de todos sus significados y prácticas” (TERÁN, 1991, p 111). Esse humanismo existencialista começa com uma impronta trágica e cética, para ir desenvolvendo, a partir, como veremos, da noção de "compromisso", um imaginário de transformação ${ }^{46}$. O marxismo que muitos desses intelectuais e outros setores da produção de bens culturais abraçarão já nos anos 60 será "una especie del género humanismo", o que permitirá "un tránsito más fluido desde el existencialismo hacia el materialismo histórico" (ibidem, p 21). Em um dos filósofos argentinos que mais decididamente fez esse trânsito, León Rozitchner, podemos ver enunciados em que a impronta humanista e sua demanda sobre o indivíduo é articulada em um lugar central e programático para o intelectual marxista. Em um ensaio

\footnotetext{
${ }^{45}$ Nome dado a uma corrente de estudantes da Facultad de Filosofía y Letras da Universidad de Buenos Aires, que incluirá alguns intelectuais que posteriormente seriam de referência, dentre outros o escritor David Viñas, o historiador Juan José Sebreli, o crítico Noé Jitrik e o psicanalista Oscar Masotta. ${ }^{46}$ Pujol (2007, p 296), muito mais centrado na produção cultural ampla do que Terán, que tem como principal referência o campo intelectual, caracteriza essa passagem como uma oscilação recorrente.
} 
em que sustenta que o capitalismo "desintegra" o homem impedindo que ele tome consciência da sua própria unidade como "centro integrador de toda referência", propõe

La única salida -pensada a nivel teórico y más general- consiste en suplantar el ordenamiento humano burgués (contradictorio no solamente a nivel lógico, sino destructor del hombre a nivel humano) por una racionalidad y organización revolucionaria (coherente en ambos niveles) que le permite al individuo concebir ese comienzo de coherencia que dé sentido revolucionario a su actividad en todos los niveles de la realidad social. Este proceso no abarca solo el sistema económico de producción, sino también el orden que aparece en las categorías de pensar y de sentir que genera a nivel individual. Cuando hablamos de racionalidad, no nos referimos a la racionalidad abstracta, puro esquema ideal que ningún cuerpo anima, sino a una teoría que, en tanto esquema de conciencia, englobe lo sensible del individuo, su forma humana material, hasta alcanzar desde ella un enlace no contradictorio con la materialidad sensible de los otros. Esto requiere, como objetivo, el tránsito hacia un sistema humano de producción que le dé término. ROZITCHNER ([1966] 1968, p 156)

Se não é difícil imaginar por quais vias filósofos e intelectuais de outros campos do conhecimento dialogam, na época, com o existencialismo, cabe perguntar-se de que maneira esses paradigmas repercutem sobre outros sujeitos empíricos, produtores culturais muito distantes do saber filosófico e das humanidades em geral, como efetivamente é visível e reconhecido em relação ao cinema, teatro, e ainda a música de tradição popular da época. Para dar apenas um exemplo: o musicólogo Norberto Cambiasso (2013, p 73-74), comentando a canção "Pipo la serpiente”, de Miguel Abuelo, que analisamos em 1.6, caracteriza a composição como "um tour de force existencialista", e afirma "Miguel escribe como si hubiese leído a Heidegger (¿o a Sartre?)”. O exemplo é oportuno, porque precisamente Miguel Abuelo é um dos pouquíssimos músicos do primeiro rock argentino não localizável nas classes médias, e que sequer completou o colegial. Apesar de ele ser um leitor assíduo de literatura, muito dificilmente tivesse lido a fenomenologia desses filósofos, como dificilmente os tenham estudado outros artistas da época posicionados em práticas de mais prestígio no campo cultural. No entanto, é inevitável ouvir, em várias dessas produções, inclusive nas músicas que aqui estamos abordando, ecos contraditórios de algumas conceitualizações relacionadas ao existencialismo, sobretudo sartriano. Presença do ser a si, e, no mesmo processo, desgarramento em relação a si mesmo, negatividade como fundamento da consciência, o ato como projeção do Para-si rumo a algo novo que ainda não é, a liberdade como condição inevitável do Para-si e do ato, e outros aspectos da complexa ontologia 
estabelecida em $O$ ser o nada (SARTRE, [1943] 1997), parecem ressoar desordenadamente em filmes, escritos e músicas. No caso do primeiro rock argentino, em coexistência notavelmente contraditória com o "percurso interior" advindo de leituras orientalistas e esotéricas como as que já mencionamos em 1.7 e 2.1 a respeito de Spinetta, ou mediadas pelos poetas beatniks como Allen Ginsberg ou Jack Kerouac (GRINBERG, 2008, p 43-44).

Já antecipamos, no Capítulo II, por que consideramos possível, nas condições sociais da época, a passagem distorcida, para outros âmbitos de práticas, de discussões que se davam nos campos intelectual e político. Cremos que, para ponderar esses ecos mais ou menos descaracterizados do existencialismo sartriano deve levar-se em conta, por uma parte, a demanda política que essa escola veio preencher, no mundo, na crise ideológica decorrente da crescente rejeição, dentro do marxismo, contra o estalinismo como regime totalitário e contra suas políticas no pós-guerra ${ }^{47}$. Altamirano (1992, p 8283) caracteriza, a respeito, um "neomarxismo" que "se quería antimecanicista y filosóficamente más cultivado que el anterior" e que tinha como referentes Sartre e Merleau-Ponty. Essa ambição era congruente também com a necessidade de repensar uma definição do humano depois das catástrofes da Segunda Guerra e do nazi-fascismo. Por outra parte, também há de se considerar o próprio esforço dos representantes desse existencialismo ateu para ampliar o escopo do diálogo em relação a um espaço muito maior que o dos debates acadêmicos. Ponza (2006, s/n) explica que "la complejidad de las reflexiones sartreanas se masificaron más bien a través de un folleto de carácter explicativo llamado El existencialismo es un humanismo, un libro que era más accesible que El ser y la nada". Com efeito, na apresentação da edição posterior que realizara desse trabalho de 1945, Elkaïm-Sartre ([1996] 2009, p 12) relata que, com a conferência que deu origem ao livro, Sartre visava a pôr sua doutrina "poco o mucho al alcance de la masa" e, também, a estreitar laços com a esquerda marxista, que favoreceriam essa confluência entre marxismo e existencialismo que apontamos a partir de Terán, Rotzichner, e Altamirano.

Naquela primeira resposta às críticas de comunistas e cristãos, Sartre proclama o existencialismo como doutrina otimista em relação ao homem, procurando assim

\footnotetext{
47 Um sintoma disso, pela negativa, é a drástica rejeição de Lukacs ([1947] 1967), em nome de uma ortodoxia ainda próxima do estalinismo, contra as tentativas que Sartre e outros realizam para fundamentar uma compatibilidade entre existencialismo e marxismo. Atribuindo-lhe uma concepção "abstrata e subjetiva da liberdade" Lukacs (ibidem, p 21) considera que essa corrente "reflete, no plano da ideologia, o caos espiritual e moral da inteligência burguesa atual".
} 
distanciar-se do ceticismo ao qual era relacionada essa corrente de pensamento filosófico, e como proposta não "quietista", mas que vê o homem como destinado a ser os atos que seu próprio projeto o leva a realizar:

El quietismo es la actitud de la gente que dice: los demás pueden hacer lo que yo no puedo hacer. La doctrina que yo les presento es justamente la opuesta al quietismo, porque declara: solo hay realidad en la acción; y va más lejos todavía, porque agrega: el hombre no es nada más que su proyecto, no existe más que en la medida en que se realiza; por lo tanto, no es otra cosa que el conjunto de sus actos, nada más que su vida. (SARTRE, [1945] 2009, p 56)

A noção de "compromisso", derivada da concepção da escolha como inevitável, ganhará centralidade nessa obra e no projeto que iniciará Sartre nesse mesmo ano com a revista Les Temps Modernes, em cuja apresentação esse conceito aparece especificado na figura do escritor ${ }^{48}$, como será poucos anos mais tarde na sua obra específica sobre o papel da escrita em relação à liberdade (SARTRE [1948] 2004).

No campo intelectual argentino, essa revista vai ser muito considerada pelas principais publicações da época (revistas como Contorno, Pasado y Presente, o La Rosa Blindada), e Sartre será, para muitos, "un ícono indiscutido del pensamiento" (Ponza, 2006, s/n). Ecos muito nítidos da formulação sartriana sobre o escritor e sua responsabilidade são visíveis, por exemplo, em um escrito de 1966 em que Noé Jitrik critica os escritores que fazem carreira na "red burocrática":

Finalmente llegan a ser académicos, figurones de diarios y revistas, asesores de aquí o de allá, jubilados con algún respiro a quienes la palabra fastidia y el compromiso resulta tan extraño como la acusación de que ni siquiera en ellos puede darse la falta de responsabilidad, de que los libros que escriben como haciéndose el tono no por eso son inocentes y formulan una especie de condena colectiva pues toleramos todo eso, nos solazamos en denunciarlo y todo sigue su curso. (JITRIK [1966] 1970, p 19) ${ }^{49}$

Porém, não é esse um processo linear, sem embates dentro da própria corrente inovadora que se manifestava na cultura argentina dos sessenta, ainda mais quando se consideram espaços de práticas mais amplos, como as artes e a militância política.

Por uma parte, o "compromisso" atua como um verdadeiro núcleo argumentativo. Sarlo (2001, p 126) lembra que "Bajo el nombre de Sartre -a menudo se trataba de eso:

\footnotetext{
${ }^{48}$ Nele lemos precisamente 'Pour nous, en effet, l'écrivain n'est ni Vestale, ni Ariel il est 'dans le coup', quoi qu'il fasse, marqué, compromis, jusque dans sa plus lointaine retraite.” (SARTRE, 1945, s/n).

49 Trata-se de reflexões sobre a situação da literatura argentina que Jitrik realiza precisamente na apresentação da edição em espanhol de uma mesa debate sobre "o poder da literatura", na qual participavam, dentre outros, Sartre, Simone de Beauvoir e o espanhol Jorge Semprún.
} 
un nombre- se difunde una teoría del compromiso que señala la posición del escritor de izquierda en la sociedad capitalista". A demanda de definição e ação política vai conformando uma tendência específica dentro do pensamento humanocêntrico:

\begin{abstract}
Ese humanismo existencialista estaba no obstante atravesado por esa carencia constitutiva del hombre que lo convertía en "una pasión inútil", aunque una observación más precisa de la curva de ese movimiento entre nosotros permite mostrar que se produce una oscilación por la cual el encuentro con la noción de revolución va marcando el pasaje de ese humanismo de signo trágico hacia otro confiadamente optimista en la capacidad de transformación de las estructuras despóticas que pesan sobre los hombres, y en las derivaciones de ese deslizamiento será posible detectar asimismo una variación desde el intelectual del compromiso hacia otro más confiado en esa posibilidad revolucionaria y más demandante de un lugar orgánico en sus relaciones con las clases subalternas. (TERÁN, 1991, p 21).
\end{abstract}

Ao apontar, no trecho supracitado, que o encontro com a ideia de "revolução" promove um deslocamento do intelectual do compromisso para outro que procura um lugar orgânico na ação política, a referência é a um processo de crescente radicalização e omnipresença do político, que irá ganhando força ao longo da década de 60 e começos dos 70. A conceitualização do compromisso mantinha um lugar autônomo para o intelectual, como pode ver-se, por exemplo, em Sartre ([1965] 1987). Mas, para um setor da intelectualidade será imperiosa a participação em algum tipo de prática "transformadora", na ação política institucionalizada ou junto dos movimentos populares. Fatores importantes para esse deslocamento foram alguns que já mencionamos no Capítulo II, como o forte influxo da revolução cubana e o que Terán (1991) denominou "bloqueo tradicionalista": a reação ativa e violenta de forças conservadoras e principalmente a repressão desatada pela ditadura de Ongania (1966-1970) sobre as expressões culturais, sobre os estudantes universitários e, finalmente, sobre os movimentos de trabalhadores.

Um claro exemplo dessa passagem do intelectual e/ou do artista para a procura de uma relação mais orgânica com as classes oprimidas em luta temos na trajetória de Roberto Jacoby na década de 60, quem, como vimos no Capítulo II, tinha contato com os núcleos iniciais do que depois seria o rock argentino ${ }^{50}$. Frequentador de diversas práticas artísticas como a plástica, o drama e as artes visuais, Jacoby mostra, desde suas primeiras manifestações, participar das convicções de que a arte deve impugnar os modos de

\footnotetext{
${ }^{50}$ No início dos 80 , já em uma época muito posterior do desenvolvimento do campo, Jacoby participará como letrista da banda Virus.
} 
produção e circulação dominantes e fundir-se com a vida. Mas o modo de tratar o político nas diferentes experiências das quais participa vai ser completamente diferente no curto espaço de três anos. Entre 1966 a 1967 promove diversas experiências no Instituto Di Tella ou com outros intelectuais que o frequentavam, como Oscar Masotta e o escritor Eduardo Costa, em torno de uma "arte dos meios de comunicação". A ideia era a desmaterialização da obra em função das linguagens mediatizadas, por exemplo, um catálogo fotográfico de uma exposição que nunca existiu, ou um informe para a mídia, também com fotos, sobre um happening que não se realizou. Em um manifesto de 1967, afirmavam:

El viejo conflicto entre arte y política que siempre se quiso superar con "contenidos" políticos, tal vez sea superado al usar los medios políticos. ¿Cuáles son los medios que queremos utilizar? Radio, televisión, prensa, posters y posters-paneles, manifestaciones, asambleas y otras formas de comunicación política. (JACOBY, 2011, p 68)

Jacoby aponta que em 1968 se produz uma grande ruptura dentro da vanguarda artística, em torno da necessidade de intervenção política efetiva. Alguns abandonam a arte e se dedicam exclusivamente à militância, outros vão produzir em relação com movimentos sociais e de resistência, como foi o caso do próprio Jacoby no grupo denominado Tucumán Arde, em cujo primeiro manifesto se lê:

Nosotros queremos restituir las palabras, las acciones dramáticas, las imágenes, a los lugares donde puedan cumplir un papel revolucionario, donde sean útiles, donde se conviertan en armas para la lucha. Arte es todo lo que moviliza y agita. Arte es lo que niega radicalmente este modo de vida y dice: hagamos algo para cambiarlo. (JACOBY, 2011, p 122)

Porém, e por isso alguns parágrafos atrás apontamos que esse "mandato" em relação à ação política não era generalizado, continuou havendo, também, dentro da ampla corrente contestatária e desconforme com o estabelecido, setores que reivindicavam a autonomia do intelectual e/ou do artista. Um exemplo foi o do próprio Oscar Masotta (Longoni, 2004), que não seguiu o caminho dos seus anteriores companheiros de experiências. E houve também quem sequer abraçou a retórica do compromisso e as práticas a ela relacionadas, e se manteve em uma perspectiva desconfiada e cética própria do "humanismo de signo trágico" que refere Terán.

Foi esse o caso de diversos artistas e escritores, inclusive alguns que tinham participado do Instituto Di Tella. Também o de alguns intelectuais, dentre os quais vale a 
pena nos referirmos aqui a Miguel Grinberg, pela proximidade que chegou a ter com os músicos do futuro rock nacional. Em torno de 1961, Grinberg começou a publicar a revista literária e cultural Eco Contemporáneo, uma das primeiras a divulgar traduções de poetas beatniks. Em vários números da revista publicou uma série de ensaios sobre o que denominava "mufados", tentando caracterizar um setor da juventude da época que também concebia como seus principais interlocutores:

Grinberg concebía a su revista como un conducto para modelar una nueva generación mufada - que gastara "energía y capacidades en crear", y ligaba su proyecto a las sensibilidades de los poetas y escritores beatniks norteamericanos, a quienes tradujo e introdujo a la escena cultural argentina. (MANZANO, 2010, p 55)

O termo "mufa", e seu derivado "mufado/-a" é uma gíria que foi relacionando-se a várias significações no espanhol da Argentina e do Uruguai. Na década de sessenta prevalecia um valor semântico que podemos explicar como uma chateação leve, que não chega a ser irritação, mas que predispõe ao mal-humor. Pensado como condição, já não como estado, ser "mufado" tinha a ver com uma desconformidade difusa e constante, mas, e como podemos ver na citação acima, de aspiração criativa. Já no primeiro número da revista aparece uma apresentação do "mufado", em um artigo com o emblemático título de "Revolución versus revolución" (GRINBERG, 1961).

Uma epígrafe do escritor estadunidense Henry Miller dá início ao artigo, anunciando que a verdadeira revolução só pode ser feita pelos indivíduos, "Trabalhando, cada um, silenciosa e independentemente", "uma revolução dos corações" (p. 62). Ao longo do texto de quatro páginas, Grinberg caracteriza os mufados como desconformes e em dissenso, mas que rejeitam também o posicionamento em categorias dadas e até ironizam das definições políticas dos intelectuais: "Los tienen podridos todos los teóricos. Para perder el tiempo y charlatanear, cualquier sitio es bueno. Arriba, abajo, atrás, adelante, derecha, centro, izquierda. Resumen: pro o contra el hombre. Los mufados: pro" (ibídem, p 63, grifo no original) ${ }^{51}$.

Em um texto de uma década depois, Grinberg apresenta um panorama do $65 \mathrm{em}$ Buenos Aires, e sintetiza, em prospectiva, características desse perfil mufado, e, mais importante para o que aqui discutimos, diferenças com outros setores da ebulição políticocultural:

\footnotetext{
${ }^{51}$ Agradecemos especialmente a Alejandro Gargiullo, aqui como técnico do Archivo General de la Nación, o acesso a essa rara publicação.
} 
Quedaba, por fin, el mufado nato, de origen desconocido y múltiple. Se producía por ósmosis, cariocinesis o susto. Brotaba en los sitios más insólitos. De alguna manera se daba cuenta de que algunas cosas no funcionaban apropiadamente y trataba de mantenerse alerta en medio de la vanagloria circundante. [...] El mufado podía invernar lustros enteros o despabilarse y apuntar hacia otros objetivos. La mufada solía estudiar sicología, sociología, danza moderna o teatro. Eran de filiación política indefinida, cosa que producía el desdén de los intelectuales "militantes", que por la fuerza de gravedad ciudadana se inclinaban sobre las mismas mesas de La Comedia para desentrañar textos sospechosos. (GRINBERG, [1977] 2008, p 42).

O "alerta ante la vanagloria circundante" remete a uma atitude desconfiada, que se focaliza sobre a politização dos intelectuais ao empregar aspas em "militantes". Também é de interesse para o que aqui estamos explicando o "desdém” que Grinberg registra, por parte dos que se sentiam definidos politicamente, em relação àqueles que viam como "indefinidos".

\subsection{A regularização como embate. Saberes e sujeitos.}

Voltamos aqui para as regularidades discursivas que fomos apresentando na sua primeira parte deste extenso capítulo, tentando explicar como cremos que o confronto de visões e representações que se dá no campo cultural argentino afeta e atravessa a série que é nosso objeto de estudo.

Comecemos por reconhecer que há, em primeiro lugar, objetos de discurso, em cujos modos de construção e reprodução intervêm "saberes" como já dados. De alguns desses objetos, e, sobretudo, do que é evitado e do que é selecionado na sua construção e encenação -o entalhe e suas lascas reveladoras-, tratamos no capítulo anterior e neste. Vimos assim determinadas figurações para o estado de amor e a paixão amorosa, a morte, as variantes da solidão, a mudança, o despertar, o tédio, a saída, a rotina, a atividade artística, o fingimento, a verdade, o nome, a dissidência, as formas de deslocamento (viajar, andar, naufragar), a rua, diversas partes do dia. E há, em torno desses objetos, perspectivas eufóricas e disfóricas, bem como relações de continuidade que se repetem. Parte dessa matéria reconfigura elementos já existentes na música urbana de tradição popular argentina e latino-americana, como vimos no capítulo anterior em relação às modalidades do melodrama e da canção romântica, e continuaremos vendo em no Capítulo VII em relação ao tango. Outra parte mostra uma relação mais nítida com outras manifestações do rock no mundo, sobretudo no que diz respeito às contiguidades de 
objetos. E cremos que o conjunto é configurado e articulado por condições de produção materializadas em uma discursividade que orienta fortemente para uma regularização.

O imperativo de mudança, com seu pré-construido de necessidade de ruptura e crise, e particularmente sua focalização na representação do indivíduo e seus vínculos é, do nosso ponto de vista, o eixo dessa regularização, o núcleo de "saberes" que estabilizará referencialmente os objetos a que nos referimos no parágrafo anterior. Ele vem dado pela determinação sócio-histórico-ideológica de uma etapa em que, no mundo, são crescentemente questionadas, em todas as áreas da práxis social, as bases da ordem dominante, e em que, juntamente, o indivíduo humano, suas possibilidades e limites para agir e transformar são particularmente interrogados, afirmados, negados. Pensamos que as instâncias de pessoa, incluindo sua articulação com a cenografia, são o aspecto da configuração enunciativa por onde privilegiadamente se plasma essa força reguladora e entra em conflito com outras tendências também perceptíveis na materialidade.

A observação feita até agora nos leva a hipotetizar -lembrando do lugar hierárquico que, no Capítuo I, demos às hipóteses na análise que nos propomos- que na regularização discursiva no primeiro rock argentino ressoaram desigualmente as diversas faces desse questionamento transformador "humanocêntrico", empregando a oportuna metáfora de Terán ${ }^{52}$. E que essas faces vão interagindo contraditoriamente. A princípio, parece indispensável o que provém das projeções discursivas, na cultura de massa, do existencialismo desconfiado, de signo cético e trágico, dando uma base inicial para a representação de mundo a ser rejeitado. Já no capítulo anterior antecipamos algo que aponta nessa direção: o "enunciar-se em solidão", gesto de ruptura em relação à música "alegre" promovida pela indústria cultural, dá lugar, na pré-história do rock argentino, a uma versão quase adolescente desse humanismo existencial entediado. Algo sintetizável na passagem que já descrevemos em 1.2, de "Billy el náufrago" para "La balsa". Essa é uma primeira delimitação da exterioridade, e o que fica dentro é "ese mundo de mierda / abandonado", com o jovem ser desconfiado, que parte de um pessimismo em relação a tudo que está dado e disponível, a tudo que "de nada sirve". Uma letra de Moris que Lernoud (1996, p 158) identifica como das primeiras, composta provavelmente em 1965,

\footnotetext{
52 Isso significa, também, que rejeitamos o mote de "idealismo" atribuído não pela crítica acadêmica mas por certo senso comum ao rock como a toda produção de signo juvenil, sobretudo dos anos 60 e 70 . A denominação "jovens idealistas", pelo geral formulada vulgarmente e sem sequer aludir ao idealismo filosófico, resulta especialmente paradoxal quando referida aos movimentos de signo juvenil dessas décadas em qualquer lugar do mundo.
} 
já generalizava, em inflexão proverbial, “Todos nacemos y todos morimos, y nadie sabe por qué y para qué" 53 .

No entanto, cremos que o processo não se detém nesse ponto. Como parte do mesmo gesto, do mesmo corte, de início e em muitas das composições pioneiras que aqui estamos considerando, impõe-se um saber sobre a mudança e o ato, que já não é o da contemplação desconfiada. Como vimos ao longo da seção 1 deste capítulo, o que se representa preferentemente na configuração enunciativa que analisamos é um momento de inflexão e um deslocamento. O ser do rock argentino, o que consegue "sair" do morrer em vida, é o que percebeu algo que poderíamos identificar com a inexorabilidade da opção, aspecto que o relaciona à circulação discursiva do influxo sartriano e sua recepção -dispersa, distorcida pelo deslocamento de disciplinas e saberes- nos campos cultural e político. Um dos aspectos do que generalizamos como "mudança crítica" em que mais se percebe a distorção, mas também a força desses ecos é nas diferentes perspectivas da entidade pessoal em relação a si própria.

Na conceitualização sartriana, a "presença a si”, é explicada como um momento em que "el hombre se capta en su soledad" (SARTRE [1945] 2009, p 22), esse "captarse sem mediação" é depois relacionado à verdade absoluta (ibidem, p 62). Naquela obra em que Sartre se direcionava, como explicamos em 2.2, a um leitor menos especializado e simultaneamente tentava uma aproximação maior com a esquerda política, essas afirmações se integravam a uma explicação sobre por que a subjetividade do indivíduo era o ponto de partida da sua escola. Dentre as diferentes assimilações indiretas que diversos produtores culturais fizeram do humanismo transformador da escola de Sartre, cremos que a que chegou -sem dúvida com muitas mediações, como já explicamos- ao primeiro rock argentino mostra uma oscilação específica.

A "solidão consigo", nas músicas pioneiras desse movimento, pode ser ponto de partida de uma projeção que, mesmo com o indivíduo como centro de cena, ponha em palavras uma série de atos criativos ou transformadores; ou, simplesmente, que enuncie uma volta sobre si. Por isso, se há -como cremos que há- um sujeito humanocêntrico na "mudança crítica", ele não deixa de alternar conflituosamente com o do ceticismo desesperançado. "Porque hoy nací", composição com que iniciamos o percurso

\footnotetext{
${ }^{53}$ Trata-se de "Esto va para atrás", também chamada "Yo no pretendo", e em alguns materiais de divulgação atribuída erradamente a Tanguito, que efetivamente a cantou e gravou em 1972. A primeira gravação dessa música é no LP solista de Moris Treinta minutos de vida, publicado em 1970, sobre o qual trataremos amaplamente no Capítulo VII.
} 
explicativo deste capítulo é, para nós, nitidamente atravessada pelo que poderíamos denominar como uma posição de sujeito relacionada aos saberes do humanocentrismo transformador. Em "De nada sirve", aquela com que continuamos nossa exposição, alternam-se contraditoriamente dizeres relacionáveis a essa posição com outros que parecem mais ligados ao saber desconfiado e quietista. Assim, enquanto no refrão se repete que o que não serve é fugir de si mesmo, e na última parte há um convite à ação e ao deslocamento ("tenés que amar, te tenés que arriesgar, tenés que sudar, te tenés que jugar, no podés tener seguridad, no podés tener ninguna propiedad, te tenés que jugar, tenés que jugarte, tenés que salir a que te rompan la cara, que te maten, que te pisen"), a continuidade das incitações e o solilóquio final apontam para a aleatoriedade do agir e a desesperança: "tenés que querer a cualquiera, tenés que odiar a cualquiera. Ay, ¿qué puedo hacer? Estoy solo y todos pasan a mi lado. Nadie me mira, o si me mira es para encerrarme. Estoy muy encerrado." E essas duas tendências, que encontramos em boa parte do corpus desse período confluem, ainda, na discursividade do primeiro rock argentino, com uma impronta também contraditória, do espiritualismo que chega via as vulgatas das crenças orientais permeadas pela corrente beatnik ou por outras leituras, como já explicamos em relação à obra de Spinetta.

Essa co-existência contraditória não nos impede postular que o predomínio, nessa primeira regularização do incipiente "progressivo", foi o do humanocentrismo transformador, o dos saberes articulados em torno do que estamos denominando como "mudança crítica". Uma comparação com manifestos dos coletivos de escritores beatniks argentinos do mesmo período, nos quais domina nitidamente o lado mais cético da visão dissidente, lembrando o caráter "mufado" que vimos no item anterior a partir de Grinberg, permite visualizar a diferença.

Recentemente foram reunidos em livro textos narrativos, poéticos e epistolares dos grupos Opium e Sunda, que, na década de 1960, foram identificados como "literatura beatnik" de Buenos Aires ${ }^{54}$. No manifesto de Opium de novembro de 1965, lemos:

Sí, Sí. OPIUM aún con el Amor y el Ocio. Qué asco, ¿no? Y, además, OPIUM con la libertad (Ojo, LIBERTAD: opción, enfrentamiento. Riesgo). Nada de servilismo. Nada de disculpas ni perdones, Cuidado. Peligro. No queremos que nadie nos dé las gracias por los servicios prestados y una patada en el culo. Cuidado. Peligro (¡por favor!). Respecto

\footnotetext{
${ }^{54} \mathrm{Cada}$ um dos nomes corresponde à revista que publicaram na época. Opium era integrado por Reynaldo Mariani, Ruy Rodríguez, Isidoro Laufer, Sergio Mulet e Marcelo Fox. Em Sunda se encontravam, dentre outros, Hugo Tabachnik, Néstor Sánchez, Victoria Slavuski José Peroni e Diana Machiavelo
} 
a "lo que está BIEN y lo que está MAL" confesamos que esta concepción burguesa, decadente, es más: decrépita, ha logrado arruinarnos el hígado y las paredes del páncreas; pero no vamos a permitir que nos arruine la cabeza, o lo que nos queda de ella... Cuidado. Peligro. [...]

¿Con salvavidas acaso? Nada de eso. Hacemos nuestra revista porque nos da la gana y como nos da la gana. Y la vendemos. Y ustedes la compran si les da la gana. ¿Estamos de acuerdo? Bien. ¿No lo estamos? Mala suerte. En cuanto a las GRANDES PALABRAS, los IDEALES, la VERDAD y toda esa cáscara se la regalamos a los que necesiten de justificativos y/o paliativos para disfrazar la realidad: todo lo que el individuo hace o dice es PRIMERO y PRINCIPALMENTE (aunque no ÚNICAMENTE, por cierto) por y para sí mismo... Así lo vemos nosotros y LO DECIMOS claramente, sin vueltas. ¿Somos valerosos? No. Somos "opiúficos". El resto de los adjetivos corren por su cuenta, amigo lector.

DE LOS OPIUUFICOS SERÁ EL MUNDO, si antes no nos revientan. (reproduzido em BAREA, 2016, p 31-32, grifos no original).

Há um gesto argumentativo inicial em relação ao termo "libertad", destacado em maiúscula e reformulado numa sequência que parece colhido da divulgação da concepção sartriana (“opción, enfrentamento. Riesgo"). Mas o que segue não parece apontar a uma ação transformadora, sequer sobre si, mas a enunciar-se como impugnando todo valor existente e postulando a vontade dos indivíduos como fundamento único, além de uma certa proclamação hedonista. Parece-nos uma tendência muito diferente, apesar da proximidade no campo cultural, do discurso que vai ganhando força no primeiro rock, no qual, como vimos ao longo deste capítulo, é enunciada a procura de uma nova condição surgida do deslocamento, do desprendimento, condição que é, ainda, identificada com o "verdadeiro". Cremos que essa encenação de mudança e ruptura, que descrevemos ao longo deste capítulo, com suas articulações de objetos e perspectivas, e ainda com o tom prescritivo presente em tantas composições está relacionada a uma posição de sujeito afetada, mesmo que de um modo específico, pelo imperativo de compromisso e, portanto, tende a afastar-se do hedonismo e do ceticismo, embora em várias canções possamos identificar um atravessamento de posições desse tipo.

Por último, é fundamental observar, no intuito de caracterizar essa primeira regularização discursiva no rock argentino, algo que o diferencia do que aconteceu, na época, conforme vimos com base em Terán, na maior parte das práticas culturais em cujo discurso ressoou esse conjunto de saberes que relacionamos ao influxo do humanismo transformador. No primeiro rock local, aquilo que pode ser relacionado à inexorabilidade da opção, a liberdade inevitável do compromisso, não se cruzou com a noção de "revolução". O "compromisso" ficou limitado à proclama de autonomia do artista e das suas comunidades, ou à contestação defensiva contra diversas formas de opressão. Dessa 
peculiaridade provém a muito assentada caracterização do rock argentino, nas suas primeiras etapas, como reticente ao político, um especial espaço de aparente isolamento em uma sociedade em que crescentemente a produção cultural, sobretudo a que se proclamava como transformadora, parecia politizar-se cada vez mais.

Algo curioso a respeito é que, nas frequentes alusões espontâneas, na crítica e na mídia, ao primeiro rock argentino ou a algumas das suas composições como "existenciais" ou "existencialistas" -vimos uma neste capítulo, mostraremos outras em capítulos posteriores-, esse caráter aparece relacionado à centralidade que nele ganha a transformação individual, mas também à sua aparente "despolitização". Um claro exemplo é a comparação avaliativa que fazem Blanco e Scaricaciottoli (2014, p 16) entre “Porque hoy nací" gravada originalmente por Manal e sua regravação décadas depois pela banda de heavy metal Hermética. Os autores, na sua comparação, opõem existencialismo v. disposição à luta: “De los inicios de los 70', el tema, en sus orígenes, con una inflexión cercana al existencialismo, se transmuta en protesta social y llamado a la lucha en los 90"'. Independente de que não conseguimos ouvir esse chamamento na versão metálica, sem dúvida a contraposição resultaria inaceitável para a vertente do existencialismo que propugnava o compromisso do artista.

A relação do discurso do primeiro rock argentino com o político será amplamente abordada no Capítulo VIII. Nele, tentaremos mostrar que não se tratou de uma “despolitização", processo impossível em um enunciar conflitivo, mas de modos específicos, que requerem descrição e contraposição, de pôr em cena tudo que tem a ver com o poder na formação social, e que ganham especial força em uma série de acontecimentos discursivos que irão produzindo algumas mudanças. Esse capítulo terá também, nesta tese, a função de abrir a passagem para o que poderíamos considerar uma segunda parte, já que trata do que propomos como uma desregularização parcial em relação ao que aqui descrevemos. Por isso, como antecipamos na Introdução, devido à sua simetria com o capítulo anterior, em tanto introdução ao regular pela exterioridade, está especificado como "não indiferença", já que trata de ausências que foram objeto de um metadiscurso sobre o campo, que também requer ser desnaturalizado.

Antes disso, os três capítulos que seguem são ainda percursos analíticos sobre este processo de regularização, que buscam ampliar e enriquecer, com novas observações sobre diferentes composições, cenas e objetos, o que neste foi apresentado. 


\title{
Capítulo V
}

\section{El Hombre de la Tapa}

\author{
(Primeiro caso)
}

\section{Um encarte especial}

Entre abril e setembro de 1969 foi gravado o primeiro LP da banda Almendra, formada por Luis Alberto Spinetta (compositor da maior parte das músicas), Emilio del Guercio, Edelmiro Molinari e Rodolfo García. O grupo já tinha publicado previamente três compactos com outras canções. Quase todas as nove músicas que integraram o LP tinham sido compostas entre 1967 e 1968. Esse disco passaria a ser um dos mais escutados na história do rock argentino, celebrado por ouvintes e também por pares e concorrentes. Dezesseis anos depois do seu lançamento, em 1985, quando o campo do rock já está grandemente diversificado e atingindo um público massivo entre setores sociais que tiveram pouco contato com a primeira época, uma enquete do jornal Clarín o consagrou como "mejor disco de la historia del rock argentino" (BERTI, 2014, p 44). A mais famosa das canções do disco, "Muchacha ojos de papel”, é conhecida inclusive fora do repertório do rock e suas vizinhanças.

Um dos aspectos mais surpreendentes da aparição desse disco, que foi denominado simplesmente Almendra, como a banda, foi o encarte, completamente insólito para a época. Em primeiro lugar, a capa não mostrava fotos dos membros da banda, identificando sua feição juvenil, como aconteceu com os primeiros discos dos outros conjuntos. Havia um desenho realizado pelo próprio Spinetta, a figura de um homem com um tipo de touca listrada em branco e rosa, e com um desentupidor por cima da touca, que também pode ser visto como um tipo de flecha de tiro ao alvo com ponta aderente de borracha, que acertou a cabeça. Do olho esquerdo do homem pende uma lágrima. No pescoço, um tecido listrado como a touca sugere que ela pode ser parte de um único lenço. Na roupa que o homem veste, na mesma cor rosada, e da qual se mostra apenas a parte superior do tórax, tem a palavra "Almendra" em maiúscula e branco. A empresa discográfica (RCA-VikTor) tentou barrar o desenho, Spinetta conta que os 
funcionários disseram ter extraviado o original (BERTI, idem, p 43), e que ele o refez de última hora.

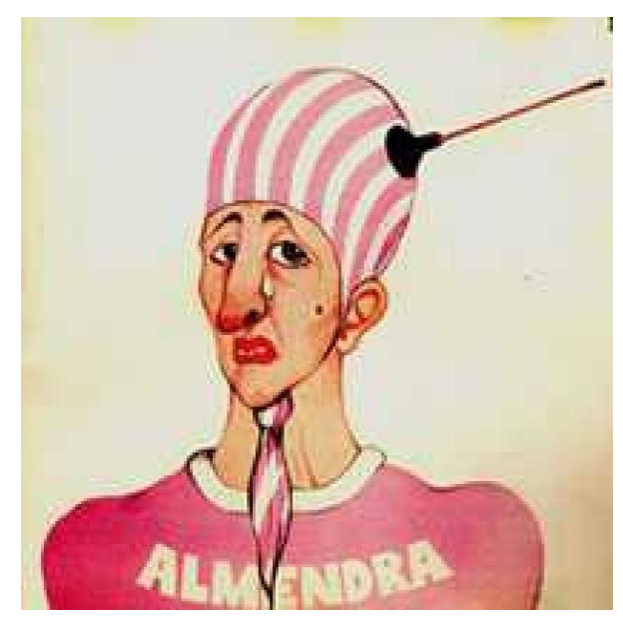

O verso da capa também continha algo extremadamente original. A maior parte estava ocupada por uma foto em preto e branco da banda tocando em um show em um espaço aberto ${ }^{55}$, o qual pode ver-se como dentro do esperável. Porém, na parte superior, a lista de músicas de cada lado do LP, em vez de estar integrada pelos nomes de cada uma, apresentava o seguinte código icônico:

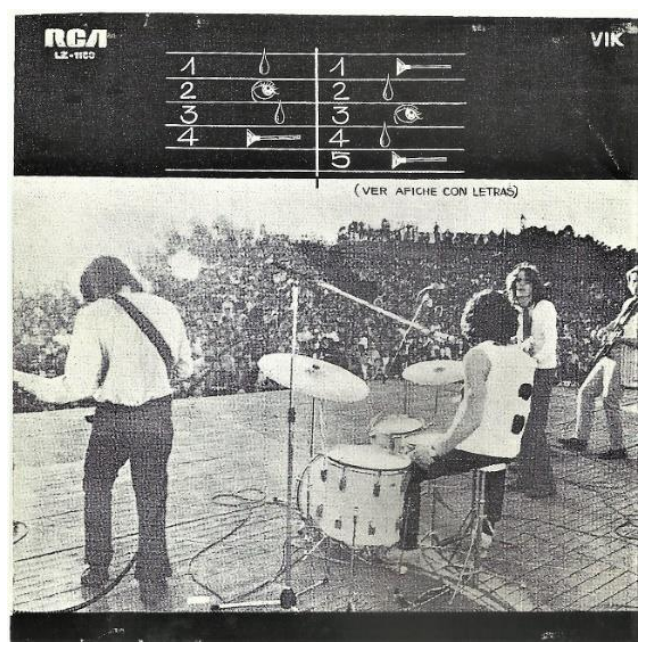

\footnotetext{
${ }^{55}$ Em um curso ministrado na Universidade de São Paulo em 2015, Claudio Díaz chamou a atenção sobre um aspecto dessa foto que também se afasta dos hábitos da indústria discográfica: os músicos não estão focalizados frontalmente. Rodolfo García e Emilio del Guercio estão de costas, Edelmiro Molinari e Luis Alberto Spínetta, de lado.
} 
Embaixo da grade, como pode ver-se na figura, havia o esclarecimento entre parênteses "ver afiche con letras", remetendo ao encarte interno. E na página interna, cada um dos três ícones aparecia relacionado às seguintes glosas que explicariam o código:

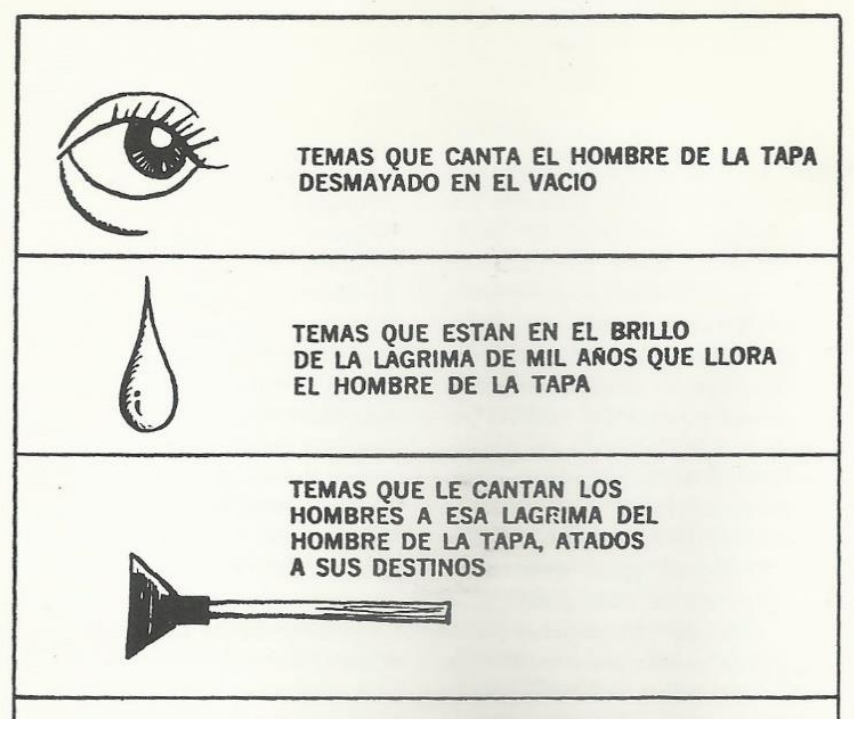

É importante esclarecer previamente, para a leitura desse pequeno glossário, que a palavra "tema", no espanhol de vários países, dentre eles a Argentina, circula amplamente, na mídia e fora dela, para referir-se a uma composição inteira e não a um fragmento nuclear da mesma, como acontece em terminologia mais especializada. A denominação, dentre outras coisas, suspende a atribuição de um gênero: ao dizer, por exemplo, "un tema de Luca Prodan ${ }^{56 " ~ n a ̃ o ~ o ~ c l a s s i f i c a m o s ~ c o m o ~ u m ~ r o c k, ~ u m ~ r e g g a e ~ o u ~}$ qualquer outra das modalidades que frequentou esse compositor. É um funcionamento parecido com o de "música" como substantivo contável no português brasileiro, por exemplo, neste trecho de Napolitano (2007, p 120, grifo nosso):

Desde o começo do II Festival de MPB da Record, duas músicas se destacaram, fazendo sucesso entre o público e o júri: "A Banda", do quase desconhecido Chico Buarque da Hollanda, e "Disparada", de Geraldo Vandré e Theo de Barros.

\footnotetext{
${ }^{56}$ Músico de origem italiana que fez parte do rock argentino na década de 80. Morreu em 1987.
} 
No encarte que estamos observando, então, "tema" refere a cada composição gravada no disco. Do outro lado do encarte interno havia as letras, acompanhadas pelo ícone correspondente, com a indicação da autoria. Assim, as músicas eram ${ }^{57}$ :

\section{Lado 1}

1. Muchacha (ojos de papel) - Luis Alberto Spinetta - lágrima

2. Color humano - Edelmiro Molinari - olho

3. Figuración - Luis Alberto Spinetta - lágrima

4. Ana no duerme - Luis Alberto Spinetta - desentupidor/flecha

\section{Lado 2}

1. Fermín - Luis Alberto Spinetta - desentupidor/flecha

2. Plegaria para un niño dormido - Luis Alberto Spinetta - lágrima

3. A estos hombres tristes - Luis Alberto Spinetta - olho

4. Que el viento borró tus manos - Emilio del Guercio - lágrima

5. Laura va - Luis Alberto Spinetta - desentupidor/flecha

A informação técnica que acompanhava as letras continha outros detalhes que se afastavam do habitual. Em "Figuración", depois de listar que instrumento tocava cada um dos músicos da banda, lia-se "Papo, Sam y demás cirqueros: coro invitado"; Em "Fermín", também depois do detalhe de músicos e instrumentos, aparecia "Ambiente: de hospicio”. Depois dos agradecimentos a colaboradores, constava o seguinte texto, em letra maiúscula:

\footnotetext{
${ }^{57}$ É importante não confundir esse disco com a edição em CD feita na década de 90, que manteve muitos elementos da gráfica do encarte, dentre eles o desenho da capa, e que inclui, além das nove músicas do original, as seis que a banda tinha gravado previamente em compactos, uma das quais é "Final", que já abordamos no Capítulo IV.
} 


\section{AGRADECEMOS AL HOMBRE DE LA TAPA ${ }^{58}$ Y A TODOS LOS HABITANTES DE ESTE PLANETA QUE DE ALGUNA FORMA U OTRA CONTRIBUYERON A LA REALIZACIÓN DE ESTE LONG PLAY}

\section{Nosso propósito e um contraoponto}

Neste capítulo, nosso objeto central de reflexão será esse disco, principalmente a partir do arranjo enunciativo proposto pelo seu encarte. Como nos outros capítulos, o desenvolvimento analítico propiciará também a referência a músicas e textos diferentes do conjunto principal dado pelo disco, enunciados com os quais encontramos relações pertinentes de contraposição ou de paráfrase. Cada um será apresentado oportunamente, mas, sobre um deles, devido às lacunas informativas que até hoje subsistem, cremos necessário fazer previamente uma introdução sucinta, que o situe no campo de estudo e na nossa pesquisa.

Trata-se do curta-metragem Buenos Aires Beat, filmado entre 1969 e 1970, com direção de Néstor Cosentino. Dura aproximadamente 17 minutos e está dedicado a mostrar o que já se perfilava como o campo do "progressivo" que iria ganhando o nome de "rock nacional". Sua realização é uma das expressões mais claras de que já havia uma percepção de campo em consolidação, na linha do que explicamos no Capítulo II a partir de Díaz (2005). Provavelmente esse e outros estudos sobre o rock argentino teriam mencionado esse curta-metragem se ele não tivesse ficado quase esquecido durante décadas. Com efeito, foi só em 2013 que o Fondo Nacional de las Artes, autarquia argentina dependente do Ministério da Cultura, digitalizou o filme, que se encontrava nos seus arquivos ${ }^{59}$. A partir daquele momento, começou a ser divulgado em alguns canais de Youtube, dentre eles o do músico Claudio Gabis ${ }^{60}$, espaço onde nós o conhecemos.

\footnotetext{
58 "Tapa", em espanhol, pode denominar capas de livros ou, como neste caso, de discos.

${ }^{59}$ Catalogado na Videoteca da instituição, seção Música: http://200.41.45.132/videoteca.html A videoteca ainda não conta com visualização on line, pelo qual indicamos sua disponibilidade em https://www.youtube.com/watch? $\mathrm{v}=8 \mathrm{kc} 4 \mathrm{t} 4 \mathrm{PnOEI}$

${ }^{60}$ Claudio Gabis foi guitarrista de Manal, banda pioneira a várias de cujas músicas já nos referimos em capítulos anteriores. Depois da separação do trio, em 1971, integrou algumas formações de La Pesada del Rock'n Roll; no Capítulo IX trataremos sobre uma das músicas que compôs nessa época. O canal que ele mantém em Youtube, Gabispace, e que subscrevemos, é um dos mais cuidadosos e consultados em matéria de rock argentino. Gabis, atualmente, dirige também um centro de formação em guitarra elétrica.
} 
Tentamos localizar participantes da produção que apareciam nos créditos, e conseguimos falar com Pedro Pujó ${ }^{61}$, que figura como "asistente musical de dirección". Nunca pudemos encontrar o diretor, Nestor Cosentino, retirado da profissão. Também fomos ao Fondo Nacional de las Artes (FNA), onde conversamos, no dia 1/2/2015, com o técnico de arquivo Santiago Valentino. Nosso principal interrogante era para quais espaços de circulação o filme tinha sido produzido. Pujó não tinha certeza, já que ele só havia se encarregado de proporcionar imagens de shows, mas supunha que o curta era para passar em cinemas antes do filme principal, ocupando um momento que nas salas cinematográficas da época era chamado de "variedades", e que combinava informações de atualidade e propagandas. Porém, o técnico do FNA explicou que o curta não teve esse caráter e que nunca passou nos cinemas. Ele ficou como patrimônio do FNA porque foi feito com recursos sobrantes de algum projeto fomentado por esse órgão. Como tal, não podia ser comercializado, apenas emprestado a instituições educacionais ou de pesquisa, se o pediam. $\mathrm{O}$ fato de o filme tratar de um desenvolvimento cultural de alcance muito restringido deve ter facilitado que, na época, fosse pouco ou nada solicitado, e que caísse no esquecimento. Uma década depois, quando o rock argentino já era um fenômeno cultural e de mercado de certo peso, provavelmente já houvesse pouco conhecimento sobre a sua existência ${ }^{62}$.

Buenos Aires Beat combina imagens filmadas em shows, sem som direto, com cenas documentais da cidade, tudo com uma trilha sonora composta por fragmentos de diversas músicas do período, de Manal, Pajarito Zaguri, Litto Nebbia, Vox Dei, Sabu ${ }^{63}$ e algumas do disco de Almendra que aqui nos ocupa. O percurso é interrompido por uma ficcionalização com atores, que aparecem inicialmente nos créditos. O principal personagem é um suposto jovem músico, entrevistado para descrever de que se trata essa corrente musical. Tanto ele quanto seu suposto entrevistador vivem, também, algumas breves cenas de situações urbanas com música de fundo. O curta por si poderia ser objeto

\footnotetext{
${ }^{61}$ Pedro Pujó, que gentilmente continuou sarando dúvidas que surgiram na nossa pesquisa sobre diversos materiais, foi um dos fundadores da gravadora independente Mandioca, que mencionamos no Capítulo II. ${ }^{62}$ Outro fator a levar em conta é que se trata de um material extremadamente precário, com péssima imagem e som, que provavelmente só pudesse interessar a pesquisadores ou colecionistas e não parecesse comercialmente explorável.

${ }^{63}$ Cantor que nunca foi considerado parte desse campo do "rock", por estar claramente localizado na produção mais convencional da indústria cultural. A presença de uma música dele no filme, estranha para uma percepção atual, pode ver-se como indicador de que o efeito de campo ainda não inibia essa coexistência nem chegava a ser claro para os produtores. Pedro Pujó atribui essa inserção ao fato de Sabu ter como manager o produtor Ricardo Kleiman, que gerenciava o programa da Rádio Excelsior Modart en la Noche, um dos poucos que, na época, dava algum espaço às tendências inovadoras no rock do mundo e da Argentina.
} 
de um estudo específico, que não é nosso propósito em ocasião deste trabalho. Aqui apenas poremos alguns momentos em diálogo com nossa abordagem do disco de Almendra.

\section{Glosas não interrogadas}

Na época do lançamento do LP, o jogo de correspondências deflagrado no encarte a partir de uma classificação icônica e das suas glosas para a identificação das músicas interveio criando uma tensão em relação ao modo de circulação dos discos no mercado. Via-se questionada a expectativa de antecipar, a partir da observação desse elemento paratextual que é a capa, quais composições conhecidas ou não pelo ouvinte o disco continha, como seus títulos podiam seduzi-lo ou conduzi-lo entre representações da música popular e de seus agrupamentos. Podemos hipotetizar que, por provir de uma banda ainda pouco conhecida, o encontro com esse "código" inusitado, combinado com a estranheza geral da arte de capa, tenha se relacionado a sentidos de pertencimento a um espaço que requer certa iniciação, reforçando o efeito de campo. Também que algo desses sentidos permaneceu por bastante tempo, mesmo quando a banda já tinha se separado e os músicos eram muito conhecidos. Afinal, só a generalização da Internet vai desestabilizar, várias décadas depois, o protagonismo da capa e do encarte como elemento paratextual.

Porém, não cremos que esse efeito desconcertante para o mercado esgote o potencial de significação do peculiar arranjo desse disco quando o que nos ocupa é a observação da discursividade no rock argentino da época. Os enunciados que ali aparecem não parecem ter sido apenas uma armadilha formal para questionar a expectativa das classificações e denominações no consumo, e mesmo que assim tivesse sido, sua aparição com essa forma específica continuaria sendo algo para interrogar. Também não nos parece que essas glosas sejam uma desmentida de si mesmas, na linha do que poderia ser uma declaração de "não ter nada a dizer", como foram alguns "jogos" posteriores no campo do rock argentino na época da ditadura militar ${ }^{64}$. Cremos que há, nessa articulação de componentes da capa, uma tentativa de metalinguagem, que sem dúvida tem traços

\footnotetext{
${ }^{64}$ Por exemplo, a música "Seru Giran", gravada pela banda do mesmo nome em 1978, composta
} integralmente com palavras inventadas. 
hiperbólicos e até pretenciosos (“desmayado en el vacío", "todos los habitantes de este planeta"), frequentes na singularidade de Spinetta como artista, mas que não desviam a tentativa da sua orientação de manifesto, antes bem, determinam-lhe mais ainda essa orientação.

O primeiro que tem chamado nossa atenção é que, tendo passado tanto tempo, sejam praticamente desconhecidas especulações a respeito desse empalme de ícones e definições, para além do que já apareceu como auto-explicação no encarte original. E isso justamente em um campo com jornalistas e aficionados tão predispostos à especulação interpretativa, e no qual os próprios músicos frequentemente tratam acerca do que "quiseram dizer" ou do que os inspirou. Sobre os desenhos e suas glosas, só encontramos repetição, às vezes levemente reformulada, do que já se lê no encarte. Este trecho do jornalista Martín Pérez, publicado no caderno Radar do jornal Página 12 em ocasião da morte de Spinetta é um claro exemplo (grifos nossos):

\begin{abstract}
Cuando se enfrentaron ante la noticia de su muerte, no fueron pocos los que inmediatamente pensaron en ese payaso triste que siempre, ahora lo sabemos, parece haber sabido cuál sería su lugar en esta historia. Y también en esa lágrima, la lágrima siempre según se lee en esa lámina- de mil años que llora el hombre de la tapa, cuyo brillo aloja temas como "Muchacha", "Figuración", "Plegaria" y "Que el viento borró tus manos". Ahí brilla el Flaco ${ }^{65}$, ahí descansa Luis, confieso que pensé esa tarde de miércoles. Todos los demás estamos en la sopapa ${ }^{66}$, como "Fermín", "Ana no duerme" y "Laura va". Somos los que le cantamos a esa lágrima del hombre de la tapa, atados a nuestros destinos. (PÉREZ, 2012, s/n)
\end{abstract}

Por parte dos próprios compositores, no caso, só conhecemos um brevíssimo acréscimo em uma declaração televisiva. Em 25/6/2008, a TV Pública da Argentina (Canal 7) dedicou uma emissão integral do programa ELEPE à memória desse disco de Almendra, convidando os quatro integrantes da banda, que rememoraram detalhes da gravação e produção, falando longamente sobre as particularidades do encarte ${ }^{67}$. No minuto 12:24, Emilio del Guercio diz: "del otro lado de la tapa del disco hay explicaciones de temas que están agrupados. La sopapa es lo más relacionado con el absurdo, lo de la

\footnotetext{
${ }^{65}$ Apelido de Luis Alberto Spinetta.

66 "Sopapa", em espanhol, desentupidor.

${ }^{67}$ Disponível em https://www.youtube.com/watch?v=fQ3-bcd5p-w, consultado em 26/11/2016.
} 
lágrima es lo más sentimental y melancólico, etcétera, etcétera". O comentário fica incompleto e nada mais é dito ao respeito nos 50 minutos que dura o programa todo.

Também nos surpreende que o encarte de modo geral não tenha sido objeto de interrogação pela pesquisa de diferentes áreas de conhecimento que abordaram o rock argentino. Embora os estudos sobre o rock argentino sejam, como explicamos na Introdução, relativamente pouco numerosos, há trabalhos com considerável detalhe sobre outros discos, e Spinetta é um compositor muito estudado. Em Ruiz (2012), Díaz (2005), e Monteleone (1993) há referências às peculiaridades do encarte, mas são breves e não abordam os ícones e suas glosas. E, fora do âmbito de pesquisa e da reflexão crítica, no amplo leque que vai da crítica interna do campo ao jornalismo mais amplo e aos blogs de público aficionado, espaços em que é possível achar todo tipo de leituras alegóricas e conteudísticas de letras, também não encontramos disquisições interpretativas a respeito, nada além de alguma interrogação sobre quem "seria" o homem da capa (Spinetta? Fermin ${ }^{68}$ ). Embora não cheguemos a esse espaço com a mesma exaustividade com que tentamos nos aproximar da crítica acadêmica, a partir do que dele conhecemos, cremos que a ausência de especulações sobre o jogo icônico tenha a ver com que as glosas já aparecem, no encarte, como uma explicação dada pela própria instância de autoria.

Autoria pesada demais, Spinetta, pela antecipação de leitura que gera no campo e à qual não é imune a crítica investigativa. As melhores abordagens que conhecemos de obras desse autor são as que conseguem precisamente deslocar-se desse efeito dado mais pelo que Ruiz (2012, p 493) acertadamente identifica como um "marcado tono místico" e "una voluntad religiosa que hasta roza cierto mesianismo".

Tentaremos suspender o mais possível, então, os efeitos dessas tradições, e abordar esse jogo a partir do funcionamento da língua e de determinadas relações interdiscursivas a que podem dar lugar, no quadro da reflexão abrangente sobre a regularização no primeiro rock argentino que tentamos neste trabalho.

\footnotetext{
${ }^{68}$ Personagem da música homônima no LP e nome que aparece também na canção "Final" -abordada no capítulo anterior-, como denominação do arlequim.
} 


\section{Assimetria dos cantares}

Começaremos pela justaposição dada pela própria configuração do glossário na forma de quadro explicativo. Em cada linha da sequência há um termo a ser desenvolvido (no caso, ícones), seguido pela sua explicação. Embora sejam os ícones os que intermediam e conduzem o percurso de leitura, porque a partir deles é que se chega ao quadro, o componente constante, "TEMAS” é o que ocupa o centro da justaposição, entre o ícone e a especificativa que lhe segue.

Essa posição central se abre para vários efeitos. Em primeiro lugar, como antecipamos em torno do funcionamento dessa palavra na circulação da música em espanhol, é um modo de denominar as composições do disco evadindo encaixá-las em gêneros ou em outras classificações da música de tradição popular. Ainda não havia, em torno do campo em consolidação, denominações estabilizadas, mas outros LPs do mesmo ano, também os primeiros dos respectivos autores (por exemplo, Treinta minutos de vida, de Moris, cujo encarte abordaremos amplamente no Capítulo VII), especificavam entre parênteses, do lado do nome da música, "folk”, "blues”, “rock”, etc. Há, assim, neste glossário, um gesto que determina o objeto primeiramente pelas cenas de reprodução e escuta musical que pudessem ser evocadas no contato com o próprio material. Não certamente a música "inclassificável" ou em uma "pura essência", como pode ter sido ou ser ainda algum desejo em torno dela. O encontro com o encarte é uma leitura historicamente situada em um espaço de práticas: neste lugar, de integrar um corpo jovem e dissidente, de fazer e de escutar a partir desse corpo, entende-se, sabe-se, "temas". Tratase, então, das antecipações imaginárias que o ouvinte de música que se aproximava desse espaço de práticas na Argentina pudesse fazer, ficando essa promessa de saber compartilhado como única fonte possível de especificação.

Uma cena do curta Buenos Aires Beat, filmado, precisamente, no mesmo período da gravação e a publicação do disco de Almendra, ilustra de um modo muito claro esse lugar de saber que já se constituía mesmo não tendo estabilizado denominações, e no qual cremos que se instala a denominação "temas" deste disco. No início, antes dos créditos, aparecem imagens documentais gravadas em um dos primeiros recitais a céu aberto, provavelmente o da revista Pinap em outubro de 1969. São pessoas do público, em planos 
muito próximos, closes ou detalhes. Enquanto isso, ouve-se o seguinte diálogo entre o entrevistador e o entrevistado ficcional que já mencionamos:

-¿Música beat? Bueno, si querés, podés llamarla música beat. Otros también le llaman "música progresiva", "rock"...

- ¿Y vos cómo llamarías entonces a lo que ustedes tocan?

-Mirá, no le ponemos nombre; "música" nada más. Tocamos música y no nos importa cómo se llame. Sí nos importa que sea buena.

-¿Y qué es buena música?

-¿Buena música? ¿buena música? No sé... Es difícil responder. Yo no sé.

Nem quem fala nem as pessoas mostradas nas imagens são músicos, o documentário situa a tendência musical que está tentando definir primeiramente pelo seu espaço de circulação e pelas características das pessoas que ali se encontram. É em cima dessas imagens que se ouve a única descrição definida, "lo que ustedes tocan". A pergunta aparentemente não tem resposta precisa, mas a resposta é precisamente o que se vê: "música que importa" é a que ali circula. Nessa chave é que lemos "temas" e que o tentamos explicar como antecipação em um espaço de práticas.

Voltando à grade e a "temas" como centro das justaposições, imediatamente vêm as primeiras formas que irão "saturando" 69 essa denominação, já que nas construções relativas da $1^{\text {a }}$ e $3^{\text {a }}$ linha do quadro temos respectivamente "temas que canta..." e "temas que le cantan...”, especificações que estabelecem o canto, mais do que a música, como primeira identidade desse objeto, que requererá, portanto, indispensavelmente de vozes e palavras.

Observemos agora a sequência de imagens do lado esquerdo, os desenhos a serem explicados. A progressão vai de algo que está situado no corpo humano a algo que lhe é exterior e se direciona a ele. Primeiro o olho, depois a lágrima que poderia brotar dele, e que já foi vista na capa, e finalmente o desentupidor ou flecha, que na capa também se vê

\footnotetext{
${ }^{69}$ Entenderemos, de acordo com Paul Henry ([1975] 1990, p 60-61), que uma formulação se encontra "saturada" quando pode entrar em paráfrase com outras no interdiscurso, visto como domínio de memória ou especificado como formação discursiva, que o autor entende em termos de Pêcheux e Fuchs (1975).
} 
como uma coisa que vem de fora e que está aderida à cabeça do homem. As relativas seguem a mesma progressão, do interior para um exterior que se redireciona: "temas que canta el hombre de la tapa...". "temas que están en la lágrima...”, “temas que le cantan...”. Assim, o homem da capa vai ocupando o centro da cenografia propriamente concebida como espaço da onde a enunciação anuncia provir (MAINGUENEAU, 2004). A gradação é dele como fonte a ele como alvo. Seu canto, o único individualizado, é representado mediante aquilo que olha, sua voz é primeiramente um olhar. E o olho na grade de ícones não se parece com aquele do compungimento da figura da capa e suas feições decaídas. É vivaz, tem cílios e uma pupila bem mais notável. Embora todos possam cantar, a primazia do ver/conhecer parece reservada a ele. Considerando que o que está sendo configurado, para além da ambientação mística, são lugares possíveis para dizer-se em um corpo do cantar/escutar, vemos aqui dois polos para esse corpo, o que se desenha em um ser singularizado e o que se dispersa em uma pluralidade relativamente incerta de cantares, que, no entanto, se direcionam a esse ser. Um tipo de assimetria que reforça o contorno do ser singular.

O que mais há na determinação desses "hombres", o "hombre de la tapa", "los hombres"? Como continua a saturação que se abre a relações interdiscursivas? Cremos que "desmayado en el vacío" entra em paráfrase com enunciados relacionados à música como experiência envolvente e eficaz sobre o corpo e a mente, que "desmaia" a racionalidade do ouvinte e a do próprio músico. Díaz (2005, p 190-218), observando o funcionamento do verbo "copar(se)"70 na gíria juvenil argentina dos anos 70 aborda relações ideológicas entre o campo do rock e diferentes tradições anti-racionalistas . Algo do "talante anticognoscitivo e anti-intelectual" que Bell ([1976] 1989, p123) vê no que caracteriza como "sensibilidade" da década de 1960, do qual o que ele denomina como "pop-rock" seria uma das expressões e que, como vimos no capítulo anterior, na Argentina se expressou em setores periféricos do campo intelectual, como os escritores beatniks e eventualmente em alguns dos músicos do progressivo. E fazemos a ressalva de que, como outros que abordaram as expressões culturais dessa época e os discursos que as sustentam, cremos que as proclamas de "suspensão" do racional ou ainda do “cognitivo" são precisamente proclamas de uma ordem de "coisas a saber"71.

\footnotetext{
${ }^{70}$ Que uma música possa "copar" remete a um tipo de fruição que anula a distância com o objeto e ocupa corpo e mente. O vazio, assim dito, seria um todo a partir do qual criar.

${ }^{71}$ Emprestamos esta denominação que Pêcheux ([1983] 2002) emprega reiteradamente para referir-se à expectativa do sujeito pragmático de ordenar o real ameaçador com que se depara. O estabelecimento de
} 
Assim, o desmaio e o vazio parecem ligar-se a sentidos de libertação claramente oponíveis ao "atados a sus destinos" que satura a formulação "los hombres". Com efeito, e ainda na linha de Henry ([1975] 1990), cremos que, apesar da genericidade que esse sintagma traz como valor possível, sua evocação da "humanidade" se vê restringida, especificada, pelas continuidades intradiscursivas na própria montagem do disco e pelas relações interdiscursivas dadas pela sua emergência nesse campo e nessas condições de produção. Um dos dois "temas" que cantaria o homem da capa é "A estos hombres tristes", homens "sem cor", assemelháveis ao "hombre feliz" receptor do Requiem no rock de Los Gatos que comentamos no Capítulo IV. Aqui a focalização não é irônica, como naquela música, é a de uma série de exortações, mas a partir da percepção de uma falta semelhante, e de uma representação de lugares de saber bem mais assimétrica do que na letra de Nebbia. Os homens que cantam à lágrima do "Hombre de la Tapa" emergem aqui, identificados mediante a seta-desentupidor que busca um alvo, mas estão previamente desenhados nos discursos sobre a vida rotineira e conformista rejeitada por diversas filiações ideológicas que coexistem nas transformações culturais da época. No documentário Buenos Aires Beat, "A estos hombres tristes" soa acompanhada por imagens urbanas nas quais se focaliza homens trabalhando na construção ou andando pelo centro com trajes de escritório administrativo. A voz e seu canto não arrastam esses homens para a disforia. Como no "Nowhere Man", de The Beatles, como o "tu" de "De nada sirve", há uma tentativa de "resgate", no caso, por meio da possibilidade de dizercantar:

Una vez vi que no cantabas

y no sé por qué.

Si tienes voz, tienes palabras,

déjalas caer.

Cayéndose suena tu vida, aunque no lo creas.

"coisas a saber" nas práticas discursivas de diferentes âmbitos garante a estabilidade referencial e coexiste contraditoriamente com os objetos construídos previamente e fora desse saber. 
As palavras devem deixar-se cair (desmaiar) para atingir o som da "vida" que é, também, singularizada. Também em Buenos Aires Beat, no minuto 4:57, o "entrevistado" dá uma explicação que parece uma síntese perfeita dessa singularização por meio da palavracanto (grifo nosso):

Está todo muy confundido. Y nosotros lo que queremos es ir a la génesis, a lo más simple. Yo soy yo. Él es él. Yo y él. ¿Entendés? Y comportarnos como realmente somos. Por eso dejamos que la música nos salga de adentro, y si sentimos ganas de gritar, gritamos.

A progressão explicativa resulta um exemplo nítido da mudança como "passagem por si" que começamos a explicar no capítulo anterior. O estado de "confusão" se supera num retorno à "gênese" (Porque hoy nací...), que é reformulada como afirmação especular, "yo soy yo", "él es él". A libertação de deixar cair as palavras encontra em algum momento esse ponto de inflexão.

Há, na segunda linha da grade, com o desenho da lágrima, a única descrição em que não aparece o cantar: "Temas que están en el brilllo de la lágrima de mil años que llora el hombre de la tapa". O verbo "estar", em espanhol, pode assumir diversos valores que se combinam com o locativo. Dentre eles, valores apresentacionais, semelhantes aos de "haber", "encontrarse" ou "verse", todas formas que poderiam substituir "estar" nessas formulação. Trata-se do que Fernández Ramírez (1987, p 159) denomina como "mención reveladora", em que o objeto é captado (no caso, os "temas") no início da sua percepção. Em Fanjul (2014c, p 179-180) avaliamos que esse tipo de construção promove, se as condições discursivas o favorecem, uma atualização da interlocução no jogo de perspectivas, em que o locutor parece direcionar o olhar do outro para o objeto. A lágrima, então, não evoca apenas o emocional: seu brilho é uma superfície do acesso ao revelado. Por isso, esse lugar intermediário relaciona diretamente o locutor-artista (desse tipo de música, desse espaço de práticas em "temas") com o interlocutor, em um plano que não é o da distribuição entre o "Hombre de la Tapa" e "los hombres", um plano posto como relativamente exterior a essa cenografia e onde se produz um convite a olhar. 


\section{Definitude e instantâneas}

Observaremos agora que existe uma instigante assimetria complementar entre os funcionamentos da determinação que acabamos de analisar na grade de ícones e glosas, e o que acontece nas instâncias de pessoa configuradas nas músicas. O que têm em comum entre si as músicas que integram cada grupo? Os conjuntos relacionados a cada ícone reúnem obras tão diferentes na sua musicalidade e nas temáticas que nelas se insinuam, e também com tanto em comum atravessando os três grupos, que parecem ter sido reunidas aleatoriamente. Desconhecemos se houve por parte dos músicos uma aposta na aleatoriedade ou em algum traço que lhes era comum. Mas não é essa nossa preocupação aqui, onde trataremos do que nós encontramos, a partir do nosso gesto interpretativo, fundamentado em aspectos da materialidade linguística que expomos à observação crítica.

Em primeiro lugar, as três músicas identificadas com o desentupidor-flecha incluem no título um nome próprio de pessoa: Ana, Fermín e Laura. Por sinal, os únicos nomes próprios que aparecem nas letras do disco todo. A teorização linguística da definitude vê o nome próprio como manifestação extrema dessa propriedade, por só poderem aplicar-se "no contexto da enunciação, a uma única pessoa" (DUCROT [1972] 1977, p 232), por conduzirem a uma máxima individualização (KLEIBER, 1981), ou por constituírem por si uma “expressão referencial” (LACA, 1999, p 895). E logo as músicas assim denominadas são as que, segundo o glossário, "cantan los hombres", uma entidade que, embora não vejamos como genérica, resulta, sim, com menor condição de unicidade ou identificabilidade, e é apresentada, pelo menos inicialmente, como um plural. Por outro lado, a instância singular, individualizada, el Hombre de la Tapa, "canta" duas músicas que dão voz a enunciadores genéricos (sobretudo "A estos hombres tristes") e nas quais são interpelados interlocutores com um grau considerável de generalização.

Vemos nessa assimetria um princípio organizador semelhante ao da progressão de ícones e de glosas, que tende a fortalecer a singularização. É dessa identidade singular, el Hombre de la Tapa, que se fala para coletivos e que surge uma enunciação genérica. E, no outro polo, os cantos plurais e dispersos de "los hombres" constroem seres marcadamente individualizados, direcionados a algo que brota daquele que está no centro da cenografia enunciativa. Caracterizamos o "le cantan los hombres" como "plural e 
disperso" e não como "coletivo" porque, no funcionamento da regularização discursiva que estamos postulando, vemo-lo mais próximo de uma pluralidade de eventos do que como um "coro".

As quatro músicas identificadas com a lágrima põem em cena também seres singulares, mas não identificados sob um nome próprio. Há, como veremos, graus diferentes de definitude e de individualização entre eles, mas não um nome. Há também um traço aspectual em comum nessas quatro canções, e que podemos relacionar com o valor locativo e apresentacional que atribuímos a "estar" na análise da glosa: sua cronografia é episódica. Elas apresentam situações relativamente pontuais, se comparadas com os estados permansivos que observamos em todas as outras salvo "Laura va", que também não é episódica como essas quatro, já que atinge um desenvolvimento narrativo com uma cronografia próxima do biográfico. Os quatro "temas" que somos convidados a ver no brilho da lágrima de mil anos se assemelham a cenas da vida registradas em algum tipo de gravura ou aquarela, que por sua tipicidade ou pelas tipicidades que desafiam insinuam a possibilidade de diversas histórias, mas que se apresentam como instantâneas.

Há uma gradação da quietude nessas instantâneas, congruente com a definitude maior ou menor dos seres representados e a especificidade do locutor. "Plegária para un niño dormido" é a mais inerte quanto ao movimento representado, e o "niño" é sempre um terceiro não interpelado cuja perspectiva só se insinua em um sonho relatado pela voz que o apresenta. Das quatro músicas é, também, aquela em que o locutor mantém uma perspectiva mais "omnisciente" em relação ao mostrado. Seu momento de direcionamento ao interlocutor para pedir que ninguém acorde o menino é o que mais atualiza a configuração que propusemos para a glosa sobre a lágrima: um convite a olhar o que nesse brilho está guardado. Em "Figuración”, trata-se de uma situação apresentada como hipotética, mas descrita como um acontecer. O entorno está detido, e o ser encenado como "tu" é principalmente contemplativo. O movimento são suas transformações involuntárias "pierdes la cabeza", "se te va la voz", "se fue tu piel". O locutor interpela com modulações proverbiais como "la realidad es caminar igual". Em "Que el viento borró tus manos" há um pouco mais de movimento, o dos elementos do ambiente (o sol, a chuva, o cair da tarde, o vento, o pátio), em torno da ausência evocada na música. $O$ locutor é mais especificável em algum lugar social de dizer, já que a voz, como a própria dêixis espacial na letra, desenha um ser instalado como testemunha no espaço onde se nota a ausência, e que inclusive se pergunta, desapaixonadamente, pela pessoa que não 
voltou. E, por último, em "Muchacha (ojos de papel)", a mulher da qual e a quem se fala aparece em movimento, e lhe é pedido que fique, descanse, durma. A cronografia é um tempo de espera, com o amanhecer como meta. O locutor é o mais especificado do disco todo, o que menos se aproxima do proverbial, da onisciência ou da pura interpelação a outros. É um quase-personagem, um locutor-amante-artista, na linha do que explicamos no Capítulo III sobre os modos de representar o "estado de amar" nas primeiras épocas do rock argentino, a visão do ser amado como exposição da criatividade.

Dessas canções que se encontram "no meio", na lágrima chorada pelo homem da capa -alvo do cantar dos homens-, "Figuración" é a que põe em uma insólita instantânea a polarização entre o saber do olho desmaiado no vazio, que consegue cantar proverbialmente, e o não saber do "atado a su destino". Poderia ser uma das configurações que percorremos no capítulo anterior, sobre a mudança crítica no ser, só que é uma versão completamente ergativa ${ }^{72}$, sem qualquer busca ou participação do "hombre". Suas transformações são, como dissemos, involuntárias. Se a proposta de Miguel Abuelo em "Oye niño" é "haz tu cabeza estallar", aqui "pierdes la cabeza” sem plano nem propósito. "Figúrate que no eres más un hombre", "tú ya no eres hombre". Um de "los hombres" que podem cantar à lágrima é posto inopinadamente diante do que poderia deflagrar um processo de despojo e saída, de ruptura, se ele conseguisse olhar diferente, se tudo não lhe parecesse "igual", enfim, se fosse parte da procura de mudança e de outro olhar, que não é sua. $\mathrm{O}$ momento em que o canto se detém e um coro de vozes recita em tom de sentença o que vai ocorrer traz um efeito sarcástico. A denominação "cirqueros" para esse coro, que, como vimos, aparece no encarte, vai na mesma direção. O "hombre" não estaria preparado para sair a esse risco, e volta a ser o mesmo. Na cronografia do amanhecer, "a partir del alba", não irá em direção a si, vai se ver caindo.

Observar o modo de co-ocorrência dos enunciados no encarte, relacioná-lo com as configurações das instâncias de pessoa e com as articulações de espaço e tempo nas músicas levou-nos à percepção de uma série de assimetrias nas quais encontramos uma coerência. Relacionamos essa coerência aos modos que temos observado neste trabalho como predominantes na representação e na valorização dos vínculos humanos, dos percursos de vida, dos conflitos e das mudanças. No entanto, essa regularização mostra

\footnotetext{
72 A ergatividade, ou inacusatividade, é um traço semântico de construções verbais que não pressupõem voluntariedade ou controle por parte da entidade afetada pelo processo (MENDIKOETXEA, 1999).
} 
também lugares contraditórios, nós e também fissuras que sinalizam outras tendências em pugna e dão lugar a posições de sujeito diferentes.

Vimos já que "A estos hombres tristes” é a expressão mais alta do dizer proverbial, quase didático. A outra canção atribuída ao homem da capa desmaiado no vazio é "Color Humano". Nela, o lugar do saber não promete. Os enunciados proverbiais ganham precisamente a forma de paradoxos sobre o saber. Mas o lugar onde mais percebemos o embate com outras regularidades é no grupo de músicas representadas com o desentupidor-flecha, cantadas pelos homens para a lágrima, como veremos no seguinte item.

\section{Laura, entre el sol y él.}

As três contém, como já apontamos, nomes próprios, mas no título, a determinação desses nome é diferente. "Ana no duerme" e "Laura va" são predicações, mas "Fermín" é somente nome. Essa exclusividade, como também a de ser um nome masculino, o põe em relação inevitável com o "Hombre de la Tapa". Não é casual que a pergunta sobre se o desenho representaria Fermín fosse frequente entre aficionados. Há algo de patetismo pela tristeza em ambas as figuras. Porém, se considerarmos o "Hombre de la Tapa" das glosas, se atentarmos para as formulações proverbiais e o lugar de ver e de saber nele depositado, Fermin é quase antitético: desvalido, levado e trazido, sem propósito próprio, em um "ambiente de hospício" que, no encarte aparece, inclusive, como mais um dado da ficha técnica. O "desmaio no vazio" do homem da capa, pela sua amplificação criadora, pode relacionar-se, em todo caso, à qualidade de visionário que a ruptura com a racionalidade dominante propiciaria, como vimos no Capítulo IV. Diferentemente, Fermín evoca uma loucura do cruel verossímil manicomial, como "Plegaria para un niño dormido", pequena fresta do disco para o realismo circundante da "Nueva Izquierda" ao que nos referimos no Capítulo II, evoca a infância abandonada na miséria $^{73}$. No entanto, alguma coisa insiste como vinculação entre ambas as figuras,

\footnotetext{
${ }^{73} \mathrm{O}$ verso "destruyendo trapos de lustrar" (destruindo panos de engraxate) direciona fortemente a música para essa leitura. Provavelmente, no âmbito da música popular argentina da época, também contribuísse para tanto a semelhança meramente temática com a valsa "Chiquilín de Bachín", de Astor Piazzola e Horacio Ferrer, gravada também em 1969. Spinetta tinha composto "Plegaria..." em 1965, antes da formação de Almendra.
} 
porque muitos elementos afastam "Fermín" de um verossímil testemunhal e o aproximam inclusive de uma figuração gloriosa: o voo para o mar levado pela ave, que seu final seja "içado".

A citação final da música tradicional infantil "Mambrú" opera como perturbação tanto dos elementos melodramáticos de comiseração quanto do direcionamento místico. O canto assume a melodia dessa conhecida canção, e o tambor e a harmônica acompanham o encerramento. "Mambrú se fue a la guerra, no sé cuándo vendrá" é reformulado como "Fermín se fue a la vida, no sé cuándo vendrá". O "pronto has de morir" sobre Fermín é, em certo modo, "desdito". O hospício também deixa de ser "ambiente". Foi para a vida fora do hospício, que seria como uma "guerra"? Fermín é um lugar de atravessamento entre o espiritualismo místico e o lado mais cético da vulgata existencialista.

Quanto a "Laura va", cremos que se afasta, em vários aspectos, do que encontramos distribuído nas classificações e na organização do disco. As outras duas músicas da flecha, encabeçadas por um nome próprio, "Fermín” e “Ana no Duerme", mostram personagens em espaços fechados (o quarto, o hospício) e um uma cronografia detida, apenas descritiva ou conjetural. "Laura va" é, como já dissemos, a única música do disco inteiro que tende à narrativa. Pensamos que, além disso, materializa um conflito em relação à regularização dominante no rock argentino da época porque se aproxima, em certo modo, de uma das "bordas" que caracterizamos no Capítulo III, a da narrativização do amor como história, não como estado. Há essa tendência em "Laura va", embora, como tentaremos fundamentar, acabe mantendo-se como figuração centrada em uma pessoa, em um único polo da dupla amorosa.

Spinetta declarou reiteradas vezes que "Laura va" está "inspirada" -ele emprega esse termo em Berti (2014, p 45)- na canção "She's Leaving Home", de John Lennon e Paul Mc Carthney, gravada no LP Sgt Pepper's Lonely Hearts Club Band, em 1967. É um lugar comum, na crítica mais interna do campo, nas suas revistas e reportagens biográficas, registrar essa alusão quando se trata de "Laura va", tendo ou não Spinetta como fonte ${ }^{74}$. Não se trata, certamente, de uma versão, sequer de citações parciais, são músicas que dificilmente se evocariam mutuamente se o próprio autor da segunda não as

\footnotetext{
${ }^{74}$ Por exemplo, esta matéria da revista Rolling Stone de 26/1/2012: http://www.rollingstone.com.ar/1443615-rescate-emotivo-laura-va-de-almendra
} 
tivesse posto em relação. Interessa-nos mais o próprio gesto parafrástico do que aquilo que possa ter constituído "inspiração". Cremos que a observação comparativa de ambas as músicas permite aprofundar o que estamos explicando em torno deste disco e também diz respeito de vários traços que vamos apontando ao longo deste trabalho sobre o primeiro rock argentino.

Em ambas as músicas, vozes masculinas põem em cena uma mulher, personagem principal do que será narrado, que deixa o lugar onde vive. Nas duas gravações há presença de orquestra de cordas, algo nada habitual no campo do rock na época. Em "She' s Leaving..." há só essa orquestra, no caso de "Laura va", à orquestra dirigida pelo compositor Rodolfo Alchourron, de trajetória no jazz e no tango, acrescenta-se o bandoneonista Rodolfo Mederos. Sobre essa base de semelhanças, passamos para as diferenças.

“Se's Leaving Home” realiza uma articulação heterogênea no jogo enunciativo. A voz do locutor-narrador é a base expositora, interrompida de duas maneiras diferentes pelas vozes que corresponderiam aos pais da protagonista que sai de casa. Por uma parte, como um lamento conjunto, na $1^{a}$ pessoa do plural, na voz de John Lennon, que alterna com a de Paul Mc Carthney, quem continua fazendo a voz narradora, cantando as palavras que dão título à canção e que iniciam cada verso:

\begin{tabular}{|l|l|}
\hline narrador (voz de Paul) & pais (voz de John) \\
\hline She & we gave her most of our lives \\
is leaving & sacrified most of our lives \\
home & we gave her everithing money could buy
\end{tabular}

Na terceira ocorrência desta distribuição, "she's leaving home" passa a ser "she's having fun”. Também aparece a voz da mãe, em discurso direto, em um diálogo representado que fica na continuidade da voz de Mc Carthney:

Father snores as his wife gets into her dressing gown

Picks up the letter that's lying there

Standing alone at the top of the stairs 
She breaks down and cries to her husband "Daddy, our baby's gone.

"Why would she treat us so thoughtlessly?

How could she do this to me?"

Na canção de Almendra, só tem a voz do locutor. Por outra parte, na música de Lennon e Mac Cartney há uma meticulosa narração dos passos da moça na saída da casa, do acordar dos pais, a descoberta e o desconsolo. Em "Laura va" há certo desenvolvimento narrativo, mas predomina a descrição fragmentária de algumas lembranças e da dimensão emocional da personagem; pena, resignação, dor, moderadas pela mediação de uma voz apresentadora, outra.

Junto com essas diferenças de narratividade -e de teatralidade, considerando o modo de apresentar o diálogo na canção dos Beatles- dadas pelo jogo enunciativo, surge outro ponto de comparação que nos parece crucial: não há lar nem família em "Laura va". Ela deixa "el pueblo ${ }^{75}$ aquel", nenhum outro âmbito é mencionado. A personagem dos Beatles, apontada só pelo pronome "she", é uma jovenzinha que sai da casa dos pais. Segundo MacDonald (2000, p 201), Paul Mac Carthney concebeu a música a partir de uma matéria do Daily Mirror de 27/2/67, que anunciava que uma adolescente de 17 anos tinha abandonado o lar paterno deixando um pequeno recado. Seu paradeiro era desconhecido e se solicitava informações. Em compensação, sobre Laura, embora na canção não se indique uma idade, as predicações que a descrevem figuram uma mulher adulta: "los años le han dado la resignación”, “aunque es grande su vida comienza aqui”.

Mais do que a diferença de idade, o que mobiliza nossa reflexão é que não apareça uma saída da casa paterna, aspecto que incorporaremos à nossa leitura de "Laura va". Mas antes vamos nos deter brevemente sobre algo mais abrangente. A não referência ao lar familiar traz ausência de um tópico maior que se encontra em "She's Leaving Home": o do conflito entre pais e filhos. Não apenas nesta música de Spinetta: em todo o corpus que levantamos com exaustividade da produção até 1971 do rock argentino não encontramos uma única música que tematize diferenças, enfrentamentos, contraposições entre alguém, como locutor, personagem ou ambos, e seus pais. E do período posterior que abarcamos, embora não possamos ser tão taxativos, o primeiro que encontramos é

\footnotetext{
75 Vilarejo, povoado.
} 
algo muito indireto, em 1974, em uma canção de Sui Generis ${ }^{76}$. Resulta paradoxal que um movimento cultural que tantas abordagens e estudos identificam, dentre outras coisas, com o conflito geracional não mostre algum exemplar em que isso seja posto como assunto, alguma “ovelha negra da família”, fuga de casa, repreensão, cobrança, ou mesmo crítica $^{77}$. A visão disfórica do mundo adulto, visão que está presente, sim, em muitas músicas, nunca é focalizada em figuras parentais. Cremos que há nisso mais uma "carência", como as que discutimos no Capítulo III, e que poderia ser relacionada com as outras, talvez pela mesma borda que parece deixar fora determinadas formas de patetismo. No período da concepção deste trabalho e da realização da pesquisa e análise do corpus ainda não tínhamos essa percepção, que atingimos perto do encerramento. Portanto, não esteve entre nossos objetivos uma reflexão específica sobre essa não encenação do conflito geracional, que poderá ser realizada em algum estudo posterior.

Cremos que, no caso específico de "Laura va", o fato de não aparecer um lar familiar, como também a não alternância de vozes, se relaciona à construção de um ser descrito a partir de seu próprio início e de um movimento auto-determinado. A própria diferença entre os títulos quanto à dêixis é significativa a respeito. "She's leaving home" ancora a perspectiva espacial no lar como ponto de partida, enquanto que "Laura va" tem o andar de Laura como eixo da cena, percurso espacial cujo ponto de partida é a própria pessoa. O ser amado será a companhia desse percurso, mas tanto o foco como a relação causativa partem de Laura e voltam insistentemente sobre ela: "Laura, pobre tu dolor/ se cayó de una oración / por eso te vas con él / por eso te vas / y hay algo de bueno en tus ojos / sin querer." Apenas um pronome, "él”, denomina o amante que a cobre de beijos. E é o sol ("y el sol también"), figura fundamental nas cenografias da mudança crítica no rock argentino, que encerra o quadro aliviado de Laura. Sendo a última música, era o disco inteiro que concluía desse modo.

Um desenho de Spinetta publicado no mesmo mês do lançamento do disco pode nos ajudar a concluir a reflexão sobre esta canção. Em 2005, o jornalista e pesquisador Víctor Pintos, na época diretor do site Rock.com.ar, encontrou um exemplar do número 2 de Alquitrán, de janeiro de 1970, uma revista pouco conhecida na época e que teve curta

\footnotetext{
76 "Para quién canto yo entonces", de autoria de Charly García.

${ }^{77}$ É curioso que essas temáticas existem, sim, na mesma época, no setor da música "para jovens" da qual o rock argentino nascente se diferencia de modo consciente e como programa explícito: os convencionais, promovidos pela indústria cultural. É claro que se trata de um conflito geracional domesticado, amenizado como travessura própria da idade, por exemplo, a reclamação porque o pai não deixa a filha sozinha com o namorado em "Yo no quiero media novia", de Palito Ortega.
} 
vida. O líder de Almendra fez, para essa revista uma série de desenhos que "explicavam" as músicas do disco, cada um com uma breve epígrafe. O correspondente a "Laura va" era este:

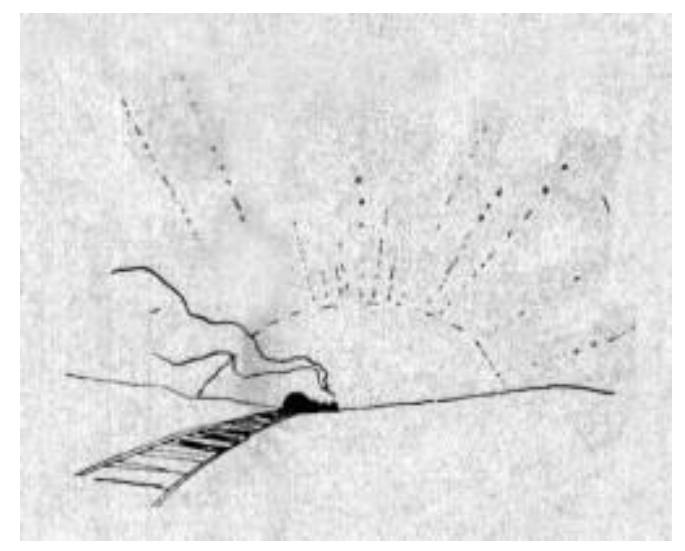

Ia acompanhado da seguinte epígrafe:

Laura va. El arreglo de lo humano con el sol. La versión vocal es "llorosa", pero a mí me gustó. El estudio lleno. Luego despegamos los corazones de los micrófonos. ${ }^{78}$

A preponderância do sol no desenho e a primeira frase do breve texto são congruentes com o deslocamento da narrativa amorosa para o "humanocentrismo". A própria Laura é transformada em um hiperônimo, "lo humano". O emprego das aspas em "llorosa", juntamente com a adversativa que a redireciona nos faz questionar de quais lugares de interdiscurso parece necessário evitar o "lloroso", o lacrimoso. Uma exterioridade dos dramas narráveis que teima em contornar a lágrima de mil anos.

\section{Aunque no eres real, vas a perder tu amor}

O final de Buenos Aires Beat acena uma história de amor dourada, para pôster setentista, mas algo súbito direciona o espectador para outro lugar.

\footnotetext{
78 Tanto o desenho quanto a epígrafe são retirados da matéria on line de Pintos (2005)
} 
Nos últimos minutos do curta, o jovem que, como vimos antes, está sendo entrevistado, se despede do seu entrevistador em um passeio público e sobe a uma moto. Ele tem um aspecto não convencional, com jaqueta de couro e o cabelo um pouco comprido, porém, muito mais dentro das convenções regradas do que boa parte dos músicos e público que foram mostrados ao longo do filme. Começa a soar "Muchacha (ojos de papel)", que acompanha o percurso do rapaz em moto, com o vento no rosto. Logo aparece ele encontrando uma jovem "muchacha" em um parque. Ela é loira, muito bela e ambos andam em câmara lenta, ela com passo mais acelerado, ele a seguindo de perto e sorrindo enquanto se ouve "muchacha, pequenos pies, no corras más..."

Depois caminham de mãos dadas, em direção a um dos lagos dos parques de Palermo. Em primeiro plano, ela sorri com a luz do sol destacando seus cabelos dourados no que poderia ser uma publicidade de shampoo. Sentados à beira do lago, durante um verso intenso ("pechos de miel, no corras más..."), ela olha para ele abaixando levemente o rosto e se contemplam como quem descobre algo mais que um parceiro ocasional. É o momento de iniciar algo com traços de perfeição.

Andando já para sair do parque, chegam a uma avenida. Enquanto estão atravessando, ouve-se um forte barulho de moto se aproximado, e, retrocedem à calçada para esquivar o veículo. A música é interrompida, fica só o ronco da moto. Quem vai na moto é ele próprio. Parece não ter estado com a "muchacha", que já não mais será vista. Continua ele seu percurso e começa a soar o final de "A estos hombres tristes": "Cuánta ciudad, cuánta sed, y tú un hombre solo...”. A tela mostra os créditos de encerramento, com vista urbana de prédios, alternando com o jovem solitário de moto, e termina o filme.

El Hombre de la Tapa rí por último. 


\section{Capítulo VI \\ Pessoa, entorno e percepção}

(Segundo percurso)

Descrevemos amplamente, nos dois capítulos anteriores, configurações recorrentes que representam o deslocamento que denominamos como "mudança crítica" no ser, relacionando-o a pré-construídos e a posicionamentos conflitantes. Dedicaremos este capítulo a um novo percurso, que acrescentará um ponto de vista sobre esse processo de regularização, observando como também se articulam nele traços discursivos presentes de muito antes em expressões da cultura de massa na Argentina, que encontramos com alguma profusão na música urbana de tradição popular.

Em muitas composições é detectável um fenômeno que já tinha forte repetibilidade no tango: um tipo de figuração na qual o ser, representado mediante a $1^{\mathrm{a}}$, $2^{\mathrm{a}}$ ou $3^{\mathrm{a}}$ pessoa, como locutor, como interpelado ou como personagem, é "percebido" por elementos da topografia como determinados astros (sol, estrelas, lua), a noite, a manhã, a cidade, o bairro, a rua, a casa e outros. Entenderemos por "percepção" não apenas o que decorre diretamente dos sentidos como a visão ou o ouvido (a nuvem nos vê, a montanha escuta teu pranto), também processos em que essa possibilidade de percepção sensorial é dada na semântica de verbos como "acolher", "esperar por", "proteger”, etc. Em trabalhos que publicamos anos atrás (FANJUL, 2002 e 2005) apresentamos e comentamos esse tipo de imagem, mas sem caracterizá-la, apenas levantando alguns casos em diversos gêneros da música argentina de tradição popular, sobretudo o tango, mas também o folklore e o rock. Alguns exemplos (em todos, grifo nosso):

En tu eterno sembrar de armonías

tierras lejanas te vieron pasar.

Otras lunas siguieron tu huella:

tu solo destino es siempre volar.

(de "Golondrina”, de Alfredo Le Pera e Carlos Gardel) 


\section{Estrella, tú que miraste, tú que escuchaste mi padecer,}

estrella, deja que cante, deja que quiera como yo sé.

(de "Zamba de mi esperanza”, Luis Prolifi).

Caminito que el tiempo ha borrado,

que juntos un día nos viste pasar.

(de "Caminito", Juan de Dios Filiberto e Gabino Peñaloza)

Cuando ya lejos de la ciudad central

los horizontes me ven.

Rutas saldar, para llegar

y mostrar que soy quien quise ser.

(de “Ayer deseo, hoy realidad”, Ricardo Iorio, banda Almafuerte) $)^{79}$.

O que chamou nossa atenção primeiramente não foi o "diálogo" representado entre o ser e o elemento da paisagem, figuração perceptível em inúmeros textos das mais variadas culturas e procedências. Dos quatro exemplos dados, essa interlocução se percebe, em "Zamba de mis esperanza", com a estrela, e em "Caminito", precisamente com a ruazinha que dá nome ao tango. E ela não acontece em "Golondrinas" nem na letra de Iorio, mas não é esse nosso foco. O que começou a nos interessar, e que aparece nos quatro casos, foi o particular direcionamento da percepção: da coisa para a pessoa. Despertou nossa curiosidade, primeiramente, pela sua recorrência nos gêneros musicais argentinos que já mencionamos, e sua raríssima aparição na música popular brasileira das mesmas épocas, diferença que não indagaremos aqui. Nos trabalhos nossos anteriores em que observamos esse tipo de figuração, apontávamos que essa localização da pessoa, ser individual ou coletivo, como alvo de um entorno que aparece dotado de percepção contribuía para um efeito de relação autossuficiente com o mundo. Mas a nossa abordagem foi sempre colateral, sem abordar o fenômeno como objeto específico de uma análise abrangente, como a que tentaremos aqui. Neste capítulo faremos primeiramente uma caracterização desse fenômeno, e, depois, na seção 2, um percurso pelos lugares nos quais aparece esse tipo de figuração no repertório estudado das primeiras etapas do rock

\footnotetext{
${ }^{79}$ Trata-se de uma banda do rock argentino muito posterior (década de 1990), identificada com o heavy
} metal. 
argentino, no intuito de relacionar essas ocorrências com a regularização que estamos descrevendo neste estudo.

\section{Indagando a figuração}

Comecemos por reconhecer que parece tratar-se de uma forma daquilo que, na retórica e na estilística, tem sido denominado como "personificação" ou "prosopopeia". Porém, a abordagem teórica do discurso que adotamos no nosso trabalho impõe que não nos detenhamos ali. Em primeiro lugar, porque, para aproveitar as potencialidades dessa abordagem, o próprio tratamento das "figuras" e/ou "tropos", quaisquer que eles forem, requer uma revisão crítica dos lugares que lhes são dados em modelos que os percebem como desvios de uma forma "geral" ou "normal". Em segundo lugar, porque tratar de "prosopopeia" significa, como veremos, de modo mais direto que com qualquer outra dessas figuras, tratar da heterogeneidade enunciativa. Cremos que os estudos discursivos têm a dizer sobre o modo como as denominações relacionadas à personificação se estabilizaram, em diversas tradições descritivas, homogeneizando processos que são enunciativamente diferentes. A prosopopeia é entendida como dar a palavra a outros e a ausentes, ou também a seres e coisas que não falam? A personificação consiste apenas em dotar algo de fala, ou também de outros traços atribuídos ao ser humano, como "pensamento" ou "emoção"? Qual é o lugar da percepção sensorial e do saber entre essas "qualidades" propostas pelos tratadistas? "Personificar" significa introduzir uma personagem? Em que medida a caracterização dessas figuras não foi determinada pelo tipo de prática discursiva que se tinha como objeto (oratória, drama, narração, lírica)? São esses alguns dos interrogantes que nos suscita o percurso pela tradição retórica e estilística. Organizaremos nossa exposição combinando, em um mesmo movimento, a revisão dessas tradições, a reflexão sobre os mesmos fenômenos a partir de um olhar discursivo e a tentativa de dar precisão à especificidade da forma que nos ocupa. 


\subsection{A prosopopeia na retórica clássica}

No tratado "Sobre o estilo", atribuído a Demétrio de Falero, filósofo peripatético do século III ac, há uma definição de "prosopopeia" que, segundo Paxson (1994) seria a primeira que se registra para essa figura. Antes disso, Aristóteles já tinha tratado sobre exemplos que corresponderiam a essa noção, mas sem empregar o termo. Na edição espanhola da obra de Demétrio, organizada por Carlos García Gual, aparece, com efeito, essa definição:

Para producir vigor en el estilo se puede usar la figura de pensamiento llamada "prosopopeya", como en: "Imaginaos que vuestros antepasados os hicieran estos reproches y os dijeran estas cosas, o la Hélade o la ciudad donde nacisteis, tomando la figura de una mujer." (DEMETRIO ([?] 1979, 107). ${ }^{80}$

No livro IX da Institutionis Oratoriae, Quintiliano ([?] 1922) ${ }^{81}$ trata sobre a prosopopeia de modo bem mais extenso que o autor antes referido, ao descrever as "figuras de pensamento", diferentes das "figuras de fala". Como o próprio Quintiliano explica, a convicção de o pensamento preceder a fala o leva a tratar dessas figuras em primeiro lugar. O autor chega à prosopopeia, que reformula em latim como "fictiones personarum" $"$, quando está tratando das figuras que mais se adaptam a "intensificar emoções", aquelas em que se introduz algum tipo de simulação. A explicação de Quintiliano sobre essa figura começa de um modo que indica claramente sua inserção na prática do orador mais do que na do poeta:

By this means we display the inner thoughts of our adversaries as though they were talking with themselves (but we shall only carry conviction if we represent them as uttering what they may reasonably be supposed to have had in their minds); or without sacrifice of credibility we may introduce conversations between ourselves and others, or

\footnotetext{
${ }^{80}$ A citação que Demétrio faz é de autor desconhecido, segundo García Gual, editor da obra. Ele também explica, na introdução, que não é certa a época de escrita do tratado, que certos estudiosos reputam a alguém posterior a Demétrio de Falero, sempre antes do século I dc.

${ }^{81}$ Toda nossa referência à obra de Quintiliano será mediante a tradução para o inglês realizada por Harold Edgewort Butler, publicada em 1922 pela Loeb Classic Library, hoje de domínio público e transcrita no site Lacus Curtius, do prof. Bill Thayer, na página da Universidade de Chicago. A edição não tem números de páginas.

${ }^{82}$ Verificamos essa denominação na seguinte edição em latim: Quintilianus. Institutionis Oratoriae. Ed. de Ludwig Radesmacher. B.G. Teubneri, 1965, p 150.
} 
of others among themselves, and put words of advice, reproach, complaint, praise or pity into the mouths of appropriate persons. (QUINTILIANO, trad..BUTLER, 1922, s/n).

Quintiliano inclui depois os casos em que não apenas as palavras, mas também as pessoas citadas são fictícias, e aquelas em que se dá voz a "coisas às quais a natureza negou voz", apresentando exemplos em que Cicero atribui ditos à pátria ou à cidade. Só quando explica que podemos também "personificar o abstrato" oferece exemplos cuja fonte são poetas, como Virgílio ou Enio, que fazem "falar" a Fama, a Virtude, o Prazer e outras entidades análogas. A prosopopeia se estende, para Quintiliano, à introdução, no discurso próprio, de potenciais falas de um locutor indefinido, como "alguém poderia dizer que...”.

Tanto a caracterização atribuída a Demétrio quanto a de Quintiliano são fincadas nas práticas retóricas. Paxson (1994, p 12-13), no contexto de um estudo abrangente sobre a personificação na história literária, propõe que na Grécia clássica, diferentemente, a noção de "prosopopeia" esteve ligada a outras práticas, como o diálogo filosófico e o drama, para designar a criação de personagens. Baseia-se na aparição da rubrica "prosopa" no início de diálogos de Platão e de peças de Eurípides, sugerindo que isso teria contribuído para a posterior estabilização do termo para designar a figura retórica.

\subsection{A fala como critério}

A observação de Paxson e o que acabamos de referir sobre os dois tratadistas da Antiguidade suscita um interrogante que está no bojo de diferenciações posteriores: por que uma palavra como "prosopopeia" é empregada para situações imaginárias em que o que se dá a alguém ou a algo é precisamente a fala? O termo é uma composição de "prósopon" (pessoa, ou inclusive rosto) com o verbo "poiein" (fazer). Fazer com que algo que não é pessoa o seja em algum aspecto, ou fazer com que uma pessoa ausente seja trazida a algum tipo de presença extrapolando tempo ou espaço. Esse "fazer pessoa" ", tantas vezes transposto a diversas línguas mediante formas cognadas de "personificação", poderia aludir a outras características humanas, não apenas à fala. Porém, sua relação com

\footnotetext{
${ }^{83}$ Mayoral $(1994,278)$ refere que alguns tratadistas registram, em espanhol, "hechura de persona".
} 
práticas como a oratória, o diálogo filosófico ou o drama (ainda mais se considerarmos a configuração cênica desse gênero na antiguidade clássica), nas quais adquirir caráter de pessoa é principalmente ter fala, pode explicar essa exclusividade, como também permite compreender que a ampliação do termo a outros campos tenha deixado de lado essa restrição. Um exemplo é Lausberg ([1967] 1991, p 241), ao propor que "se puede distinguir entre la fictio personae mediante discursos y la fictio personae mediante el resto del comportamento personal" 84 . Reconhecendo essas tradições posteriores que ampliam o alcance da figuração, Paxson $(1994,93)$ propõe que o primeiro critério diferenciador para uma taxonomia da prosopopeia deve ser a presença ou a ausência de fala atribuída a essas entidades.

Com efeito, em vários dicionários e compêndios de estilística ou retórica esse é um parâmetro de distinção. Marchese e Forradelas (1994, 318), por exemplo, propõem a seguinte classificação: "La personificación consiste en atribuir a un ser inanimado o abstracto cualidades típicas de los seres humanos. Si el ser personificado se convierte en el emisor del mensaje, se produce la prosopopeya; si en destinatario, el apóstrofe." Isto é, a prosopopeia seria uma forma particular de personificação, na qual a entidade fala. Se não há fala, trata-se apenas de uma personificação. Classificação análoga, distinguindo pelo mesmo critério "personificação", "apóstrofe" e "prosopopeia” realizam Mezaleyrat e Molinié (1989, 262-263), apenas diferindo na inclusão de pessoas mortas como "personificados" e em que, devido à sua inserção teórica, não definem o atribuído como "qualidades típicas" dos humanos mas como o "papel funcional de uma pessoa" 85 .

Outros compiladores, diferentemente, logo aqueles que colocam em um plano secundário a atribuição de fala ao ser personificado, consideram "prosopopeia" e "personificação" como sinônimos e agrupam todas as modalidades indistintamente sob um ou outro desses nomes. É o caso de Estebánez Calderón (2006) e de Moisés (2004). O primeiro dá uma definição na qual vale a pena determo-nos um pouco:

Prosopopeya (o personificación). Es una figura lógica consistente en la atribución de cualidades o actividades humanas a seres inanimados (piedra, agua), animados (plantas, animales) y a conceptos abstractos (sabiduría, culpa). En la retórica clásica se consideraba también prosopopeya al recurso literario de atribuir la

\footnotetext{
${ }^{84} \mathrm{O}$ tratadista refere o termo "prosopopeia", mas emprega sempre a formulação latina.

${ }^{85}$ No original "le rôle fonctionnel d'une personne vivant soit à une personne mort soit à un être ou à un object non humains".
} 
palabra a personajes ausentes a los que se evoca en un acto de comunicar sus ideas y pensamientos. (ESTÉBANEZ CALDERÓN, 2006, 881-882).

No trecho, a tradição retórica, na qual a prosopopeia era relacionada exclusivamente à fala, aparece diferenciada e em um lugar adicional da definição. E, por outra parte, além de "qualidades", o tratadista inclui a atribuição de "atividades" humanas. Ele dá como exemplo um trecho de Garcilaso de la Vega no qual aparecem processos perceptuais, emocionais e intelectuais:

\footnotetext{
Con mi llorar las piedras estremecen

su natural dureza y la quebrantan;

los árboles parece que s'inclinan

las aves que m'escuchan cuando cantan

con diferente voz se condolecen

y mi morir cantando m’adivinan.
}

Moisés (2004, 374-375) também identifica prosopopeia com personificação e, além de caracterizações semelhantes às que aparecem nos autores que já citamos, inclui a denominação "espécie de humanização ou animismo", que parece diretamente derivada da ampliação da noção de prosopopeia a determinados caracteres da narrativa. Com efeito, Paxson $(1994,35)$, cujo estudo desses processos é orientado a analisar seu papel em narrativas ficcionais de diferentes épocas, propõe diferenciar entre uma "figura de personificação" que se registra em um momento pontual de um texto (nas suas palavras, um "ornamento retórico local") e a personificação como criação de uma personagem que participa do conjunto da história narrada ("personification character"). Assim, termos como "animização" ou "humanização" parecem adequar-se mais a histórias em que um objeto tem traços vitais e como tal é incorporado à trama, ou ao protagonismo de animais nas fábulas. Vários dos compiladores que temos consultado emparentam a prosopopeia com esse tipo de relatos (MARCHESE e FORRADELAS, 1994; MAYORAL, 1994) mediante a noção de "alegoria". Esse caminho, como demonstrou Todorov (1975), pode levar para as problemáticas do maravilhoso na literatura, domínio que se afasta do tipo de fenômenos que nos ocupa. Na letrística das composições musicais que abordamos, o mundo apresentado não tem as dimensões espaço-temporais da narrativa ficcional, nem 
se predetermina nele uma permanência do ser objeto da prosopopeia. E, fundamentalmente, os lugares sociais de fala relacionados ao rock e a praticamente qualquer outro gênero contemporâneo da canção urbana não nos parecem próximos com os do enunciador do conto maravilhoso.

\subsection{O lugar da percepção}

Feito este primeiro levantamento, passaremos a indagar, em torno dele e acrescentando algumas outras fontes, dois problemas que nos interessam para nossos objetivos. Um é a diferenciação ou não, nessas tradições, do tipo específico de imagem que nos ocupa, no qual, reiteramos, uma ou várias pessoas são objeto da percepção, principalmente visual, de uma entidade não animada que faz parte da paisagem ou do entorno. Outro é a inserção desse fenômeno na reflexão discursiva que estamos desenvolvendo, o que implica formular hipóteses sobre seus possíveis efeitos no quadro da enunciação, bem como ponderá-lo na perspectiva de uma teoria do discurso que situa as figuras em condições de produção específicas.

Vários dos exemplos que encontramos nos compiladores que referimos correspondem à percepção, como o "escutar" das aves em Garcilaso, no trecho citado por Estébanez Calderón que já reproduzimos. No seu trabalho sobre a prosopopeia nas Soledades, de Góngora, Lechuga (2015) apresenta casos como um em que o a amanhecer vê ordenhar leite (p 63), ou outro em que um córrego escuta um coro de aves (p 107). Mas nenhum dos autores que já referimos diferencia a percepção sensorial ou alguma das suas formas específicas como uma das "características", "qualidades" ou "funções" humanas que a prosopopeia depositaria nos seres personificados. Paxson $(1994,42)$ considera, para a "personification", a atribuição do pensamento e da linguagem. Em um processo figurativo que ele identifica com o nome de "topification", inclui os casos em que alguma abstração se substancializa em um espaço geográfico, por exemplo, uma "paisagem moralizada". Se considerássemos a visão, outras formas de percepção sensorial ou o saber que delas deriva como qualidades abstratas, talvez essa categoria poderia se aproximar de algumas das imagens que são nosso objeto de estudo, mas de um modo muito indireto. Wales (1989, p 342) inclue, entre as características humanas conferidas às coisas inanimadas pela personificação, os sentimentos e emoções, 
resgatando para tanto a denominação "falácia patética", que atribuem ao escritor inglês John Ruskin (1818-1900). É claro que podemos supor que, para esses compiladores, a visão e a escuta possam ser consideradas como integradas nos processos de pensamento ou como modalidades do sentimento, mas não há explicitações a respeito nos seus compêndios.

Quem mais se aproxima de considerar especificamente a visão e a audição é Mayoral (1994). Cabe destacar, em primeiro lugar, que este é o único crítico contemporâneo, dentre os que dialogam com desenvolvimentos da Linguística, que situa a prosopopeia afetando o jogo enunciativo, enquanto que outros a caracterizam no plano dos "papéis funcionais" (MEZALEYRAT e MOLINIÉ, 1989) ou dos "semas" (TODOROV, 1967). Embora limite os efeitos enunciativos ao "espacio del texto" ( $p$ 278), manifestando uma concepção imanentista, Mayoral dá um passo na direção de especificar a percepção nos processos de personificação figurativa. Precisamente por considerar que esta instala um marco enunciativo, destaca entre as "qualidades humanas" atribuídas às coisas prosopopeizadas "muy en especial la capacidad de hablar/escuchar" (MAYORAL, p 279, grifo nosso), e cita o retórico espanhol Jiménez Patón: “dando habla o alguno de los sentidos a cosas que dellos carecen" (ibid, grifo nosso).

\subsection{Uma proposta a partir da enunciação}

Pela nossa parte, cremos que a figuração de um processo perceptivo, sobretudo de visão ou de audição, recaindo sobre alguma das entidades pessoais e atribuído a um objeto representado como inerte intervém, sim, no jogo enunciativo. Em primeiro lugar, é necessário reconhecer algo mais geral: a partir de um referencial teórico como o que assumimos neste trabalho, que questiona a unicidade do sujeito falante, toda enunciação pode ser vista como uma "prosopopeia", porque sempre é produzida a partir de lugares de fala que não se reduzem à identidade do falante empírico, e porque constantemente delega a voz, mediante os procedimentos da heterogeneidade mostrada, a uma complexidade de seres discursivos. O que é que se acrescenta, então, a esse quadro, quando é dito que um elemento do entorno olha, escuta, vigia ou espera um dos protagonistas? É acrescentada -ou desdobrada- uma perspectiva, e, portanto, conforme vimos no Capítulo I a partir de Zoppi Fontana (2004), um lugar de conhecimento. 
Cremos que é um tipo de perspectiva de um status diferente da que pode ser reportada de um personagem do enunciado, inclusive quando o locutor assume seu ponto de vista, em formulações do tipo "empiezan a mirar el techo y en el techo no hay nada" ou "Veo mares de algodón" 87 . A visão desse personagem é a de alguém "de quem se trata", uma entidade em relação à qual já se instalou uma perspectiva de observador, e à qual já se atribuíram papéis no esboço de trama ou esboço de mundo que cabe em uma canção. No tipo de imagem que aqui estamos considerando na poética do rock argentino, as entidades que "percebem" (sol, lua, nuvem, amanhecer, cidade, céu, etc.) estão muito longe dos "personifications character" que estudou Paxson. Sequer são postas em uma continuidade de ações ou mantidas em foco, como acontece, por exemplo, com os rios, o mar, o céu e outras nas prosopopeias gongorinas que estuda Lechuga $(2015,99)$, nas quais "la naturaleza acapara el espacio que debería dedicarse a la narración principal", ou com os objetos inanimados nas imagens que Aristóteles ${ }^{88}$ elogia na obra de Homero. Também não dialogam nem entre si nem com os personagens, como as "qualidades abstratas" que Quintiliano traz da obra dos poetas latinos. Estas entidades, no tipo de figuração que estamos tentando caracterizar, são um perante quem é posta a situação representada, um perante quem quase imóvel, posto exclusivamente para isso, e de modo pontual e em um único ponto da música. Essas três qualidades, a percepção como ato único, a pontualidade e a inércia lhes restam identidade narrativa. Mais do que uma personificação do ente inanimado parece tratar-se de uma reificação do ato de olhar depositado em um elemento saliente do entorno ou da paisagem ${ }^{89}$. Vejamos este exemplo, do tango "Mis amigos de ayer”, de José María Contursi:

Esta noche tengo ganas de aturdirme de recuerdos con el frío denso y lerdo de las cosas del lugar, recorrer las viejas calles por el tiempo transformadas y entre piedras olvidadas empaparme de arrabal.

Me contemplan con asombro las estrellas y esta esquina

\footnotetext{
${ }^{86}$ Em "De nada sirve", de Moris, que abordamos no Capítulo IV.

${ }^{87}$ Em "Color humano", de Edelmiro Molinari (com Almendra), que vimos no capítulo anterior.

${ }^{88}$ Consideramos a edição da Retórica em espanhol por Quintín Rancionero, publicada pela editora Gredos em 1990. Aristóteles não emprega o termo "prosopopeia", e inclui os fenômenos que depois a retórica estudaria com esse nome como "metáforas por analogia". Sua avaliação positiva da animização pelo poeta de objetos como flechas, lanças e pedras provém de que, desse modo, eles são postos "em ato" (p 540-541). ${ }^{89}$ Paxson (idem, p 45-48) desenvolve uma interessante reflexão sobre a complementariedade entre "personificação" e "reificação".
} 
con perfume de glicinas y colores de malvón.

Debo estar acaso viejo, melancólico y más flojo,

que me sale por los ojos esta cálida emoción.

O ato contemplativo por parte das estrelas e da esquina pareceria escapar do plano do que é representado para voltar-se sobre a totalidade da cena, como se fosse externo a ela. Cremos que a emergência desse ato de percepção atribuído a um elemento do entorno atualiza um pressuposto de que "há o que se conhecer" sobre isso que é o mundo encenado, e esse é um pressuposto precisamente da enunciação. Na linguagem verbal, "há o que olhar" é nada mais, mas nada menos, que "há o que dizer", e no mesmo ato apontar que "[aqui, agora, entre nós interlocutores] se fala disto" ${ }^{90}$. Por esse motivo, cremos que o efeito se vincula ao que Zoppi Fontana (2004, p 62) denomina "ele observador", uma instância que surge da reflexividade da enunciação sobre si mesma como "divisão espelhada" (ibidem), e à qual pode ser atribuído o que nos estudos de narrativa literária se chama de "omnisciência", e que em outros tipos de discurso podemos caracterizar como um "interlocutor ideal", no sentido de que possuiria "conhecimento exato" do que representamos no discurso. O olhar do locutor, já não desdobrado em personagem, é o que converge com essa perspectiva, porque é esse olhar, no fim das contas, quem focaliza a entidade "percebendo". No exemplo citado de Contursi, é o locutor quem "vê"/diz que as estrelas estão contemplando a caminhada pelo arrabalde, e chama assim a atenção sobre que aquilo precisa ser visto à vez que está sendo visto/dito. Cremos que esse processo tende a aproximar o locutor de uma modulação de "enunciador universal" (GUIMARÃES, 2005, p 26), porque separando momentaneamente sua fala do conflito representado traz algo como pura evidência. E que também tem efeito sobre a mostração do personagem "observado", seja este um desdobramento do locutor em $1^{a}$ pessoa, um interlocutor representado também como personagem, uma $3^{\mathrm{a}}$ pessoa, ou um coletivo que inclua várias dessas possibilidades. Efeito análogo ao da reflexividade da enunciação, mas na cenografia: "tu, que és tu" / "eu que estou mesmo aqui"; ostensão do ser re-ostentado por (perante) o observador externo. E efeitos ambos, tanto aquele sobre o enunciador quanto este sobre o representado, que ganharão orientações para

\footnotetext{
${ }^{90}$ A especificação entre colchetes tenta estabelecer que não cremos que se trate de uma passagem para um enunciador genérico (GUIMARÃES, 2005, p 25). Como veremos logo, relacionamos este tipo de figuração a outra forma de afastamento do lugar social de fala, também considerada por esse autor.
} 
determinados sentidos segundo as relações discursivas em que se inscrevam, não pela forma em si.

Antes de passar para o modo como esse tipo de figuração se insere na regularização discursiva do primeiro rock argentino, terminaremos de situar seus parentescos imediatos, já que o recorte que estamos fazendo é diferente do que preveem as classificações de figuras retórico-poéticas.

Ao abordar essa reificação como perspectiva no jogo enunciativo, encontramos, para ela, proximidades que não são as diversas formas da prosopopeia, nem a substancialização de qualidades, nem a animização de objetos, mas as figurações pontuais, em objetos do entorno, de outros processos no eixo da percepção-conhecimento. Então, próximas do que se opera nas imagens em que esses elementos veem ou escutam são as figurações em que eles reconhecem, esperam, acompanham perceptivamente a pessoa, como em vários exemplos que apresentaremos neste capítulo. Também aqueles em que lhe direcionam um gesto, como o que abordaremos depois em "Avenida Rivadavia", de Javier Martínez, "la mañana incoherente me sonrió". Ou aqueles que combinam gesto e olhar, como no tango "Volver", de Carlos Gardel e Alfredo le Pera: "bajo el burlón mirar de las estrelas, que com indiferencia hoy me vem volver". Em uma modalidade um pouco mais distante, há o gesto que pode perceber-se também como a representação de uma fala, como o "saudar" nesta música de Charly García de um período posterior ao que abordamos neste trabalho, que alude ao exílio de artistas durante a ditadura militar:

Por el ecuador y el trópico

el sol saluda a nuevos vagabundos.

(de "Autos, jets, aviones, barcos", 1979).

Mais distante ainda estaria a própria fala, em discurso direto ou indireto, que aproximaria a entidade de um "personification character", inserindo-a na ficcionalização, por incipiente que ela seja em cada música, e desfazendo, em consequência, o efeito de observação externa. Não encontramos, no rock argentino, nenhum caso desse tipo, figurações em que algum elemento inanimado do entorno faça uso da palavra. No período que revisamos exaustivamente podemos asseverar que não registramos nenhuma, como 
também não a achamos nos espaços que conhecemos com maior abrangência em épocas posteriores. Só encontramos um caso de representação da fala mediante um verbo dicendi, "Mañanas campestres", de Gustavo Santaolalla, em que se canta "el viento nos cuenta la historia de un lugar". Porém, nenhum em que a fala se represente mediante alguma formulação.

\subsection{Figura e regularidade}

Havendo examinado as características deste tipo de figuração e formulado nossa análise dos seus efeitos sobre a articulação das instâncias de pessoa, cabe a interrogação sobre como ela se relaciona com os processos de regularização que são o objeto principal do nosso trabalho. Parece, a princípio, razoável que esse tipo de imagem seja relativamente recorrente em uma série que, como estamos caracterizando, guarda relações interdiscursivas com determinadas vulgatas do existencialismo, e que abunda em cenografias com uma configuração de tempo, espaço e pessoa na qual o direcionamento do ser sobre si faz parte de narrativas de superação, integrando-se a sentidos de rebeldia e questionamento. Porém, também devemos levar em conta que o mesmo gesto interpretativo que nos fez ir encontrando essas e outras regularidades, e articulá-las em torno de uma hipótese foi também o que nos levou a perceber com certo destaque figurações que, a partir de outro olhar, pudessem passar desapercebidas. E, por outra parte, como já apontamos no início deste item, a imagem de entidades da paisagem e do entorno contemplando o ser tem muitos antecedentes nas expressões culturais argentinas de tradição popular.

No tango, por exemplo, era sem dúvida mais abundante do que no rock: só a partir do nosso conhecimento empírico conseguimos identificar mais ocorrências do que as que encontramos nos primeiros anos do rock em um levantamento rigoroso. E praticamente nenhum dos fatores que encontramos na regularização discursiva do primeiro rock que estamos descrevendo seria aplicável ao tango. Componentes importantes do que no Capítulo III fomos postulando como exterioridades constitutivas da regularização do rock argentino estão fortemente presentes bem no interior do tango: a narração da morte individual nas suas mais diversas formas, determinadas configurações da narrativa amorosa, traços do melodrama. Por isso, não se trata de buscar uma relação de 
correspondência entre figura e produção de sentido no discurso, que, como explicaremos a seguir, contradiria os direcionamentos teóricos que assumimos, mas de interrogar a especificidade do que essa figuração, cuja propagação na música urbana argentina precede claramente o campo que estamos estudando, pode vir fazer especificamente neste tipo de regularização, e não necessariamente em outras.

Para tanto, é necessário compreender o que aparece como "figuração" como relacionado a uma ordem e não a um desvio. A tradição retórica e estilística reservou às "figuras" e "tropos" um status de saída do "comum", do "direto", do "neutro", concepção que nos tratados, glossários e manuais que temos referido não apenas se encontra na caracterização do que sejam as figuras, mas na sua própria classificação e definição. Quando Demetrio ou Quintiliano diferenciam entre "figuras de pensamento" e "figuras de fala", é por que tratam de especificar sobre a "normalidade" de qual dessas dimensões ("pensamento" ou "fala") elas atuariam. Algo análogo acontece, a pesar dos muitos séculos que os separam da Antiguidade, quando Estébanez Calderón localiza a prosopopeia como figura "lógica", ou Mayoral como "pragmática". Abordagens posteriores dos tropos oriundas da Linguística substituíram essa preceptiva espontânea por uma normalidade assentada na representação de cientificidade, que manteve, de outro modo, a mesma percepção de "desvio". Assim, Wales (1989) classifica as figuras segundo qual ordem da "gramaticalidade" afetam. Todorov (1967, p 107-108) abandona a normatividade lógico-moral ao recusar que ao tropo ou figura se oponha uma "expressão própria", mas para assumir uma normatividade linguística, caracterizando as figuras segundo a "regra linguística violada" "91 Assim, emprega a denominação "anomalias", e as classifica segundo o nível do funcionamento linguístico no qual se produz a "violação". A prosopopeia é localizada no nível semântico, com base numa análise de tipo componencial, segundo a qual ela se funda "sur 1'omission des sèmes Humain \& Présent" (ibid, p 108).

Algumas correntes da semiótica e dos estudos discursivos que abordaram a metáfora contribuíram para tirar as figuras e tropos do lugar do incomum e do acessório, como também para chamar a atenção sobre a necessária implantação sociohistórica da sua interpretação. Barei (2012, p 217-218), a partir da denominada "semiótica da

\footnotetext{
91 Literalmente, "nous opposerons chaque anomalie non à l' 'expression propre' mas à la règle linguistique enfreinte." (TODOROV, 1967, p. 108)
} 
cultura"92, propõe que os tropos e figuras não são ornamentos da linguagem, mas formas de consciência não individual, que permitem indagar sobre o funcionamento de "porções inteiras da cultura" e cuja interpretação é determinada pelo "contexto cultural". Por outra parte, e dentro do referencial teórico que assumimos neste trabalho, Michel Pêcheux, em um escrito de 1984, propõe que o funcionamento metafórico se explica porque a construção dos objetos na materialidade verbal circula por diferentes "regiões discursivas", sem que nenhuma delas possa ser considerada "originária" (PÊCHEUX [1984] 2011, p 157-158).

Não há, em consequência, "uma estrutura sêmica do objeto, e em seguida aplicações variadas dessa estrutura nesta ou naquela situação" (ibid, p 158). A metáfora não é um desvio respeito da alguma "naturalidade" semântica do objeto de referência que precederia sua circulação. O efeito de metáfora em torno de tal objeto surge de um determinado regime de significação que de maneira nenhuma é universal, ele é atrelado a uma determinada ordem de regularidades sócio-historicamente determinada, uma região específica do interdiscurso ${ }^{93}$. Embora Pêcheux exemplifique esse texto principalmente com ocorrências lexicais, cremos que o mesmo princípio é aplicável ao tipo de figuração "reificante" que estamos analisando. Observamos sua recorrência em lugares, como veremos neste capítulo, cruciais do fio do discurso em determinadas canções. Propomonos, então, a indagar sua aparição não como violação de uma regra sêmica ou pragmática, mas como manifestação de uma regularidade. Há especificidades que nos permitam hipotetizar como esse tipo de figura se integra na regularização discursiva primeira do campo da música urbana de tradição popular que estamos considerando?

Por uma parte, diremos que esse processo de regularização integra, ao material discursivo dado pelo processo de renovação ideológica e cultural dos anos 60 com o qual entra em relações de paráfrase, um material figurativo previamente existente na discursividade da música de tradição popular argentina. No tango, Campra (1996, p 5456) identifica algumas dessas imagens com uma "retórica animista"94 que participa da construção imaginária do espaço idílico do arrabalde. É claro que no rock dos 60-70 não

\footnotetext{
92 O principal referente dessa corrente é Iuri Lotman (1996).

93 Já na sua obra clássica Les verités de La Palice, Pêcheux ([1975] 1997, p 123), no contexto de uma crítica a um artigo sobre a noção de ideologia, antecipa essa rejeição a que exista um sentido "primeiro", "não metafórico", "para o qual o objeto seria um dado "natural', literalmente pré-social e pré-histórico".

${ }^{94}$ A autora, única estudiosa do tango que encontramos que aborda essa figuração, não realiza um percurso exaustivo sobre ela.
} 
cumprem essa função, e, como veremos no Capítulo VII, o bairro praticamente não é tópico do seu discurso. Outra diferença extremadamente visível entre o tango e o rock a esse respeito são os objetos mais "prosopopeizados". Enquanto no tango são astros noturnos, como a lua e as estrelas, e o sol nunca é posto nesse lugar, no rock, como iremos mostrando neste capítulo e no próximo, o sol e o amanhecer são os objetos mais recorrentes nessa figuração. E o protagonismo do sol não é apenas um tópico do rock no mundo que a nascente música progressiva argentina incorpora. Vimos, em todo o capítulo anterior, que a cronografia do amanhecer é um dos componentes de forte repetição na configuração da "mudança crítica".

$\mathrm{Na}$ tentativa, então, de que indagar esta "personificação do entorno" ou “ reificação da perspectiva" ajude ao objetivo central deste trabalho, de aproximar-nos dos processos de regularização/desregularização no primeiro rock argentino, iremos percorrendo, na seção seguinte, os casos do levantamento que fizemos em torno da ocorrência desse tipo de figuração. O conjunto do percurso tenta ser uma segunda aproximação da saliência que foi aberta no Capítulo IV. Somente não incluiremos aqui uma das composições em que encontramos a figura que nos ocupa, "Pato trabaja en uma carniceira", de Moris. Ela será objeto da análise abrangente que desenvolvemos no Capítulo VII, destinado também a abordar a problemática da encenação do interpelado.

\section{Prosopopeias, deslocamentos}

\subsection{Pulando do melodrama}

Dentro das gravações mais antigas, a primeira em que localizamos um caso que se aproxima desse tipo de figuração é "El niño y el mar", de Los Gatos, que apareceu no LP "Viento, dile a la lluvia", de 1968. Ocorrência particularmente interessante por ser Los Gatos uma banda claramente transicional em direção à musicalidade do movimento e, cremos, também, no que diz respeito à sua primeira regularização discursiva. Ainda há, em Los Gatos, como já apontamos em outros momentos deste trabalho, uma coexistência com aspectos que irão ficando fora do "dizível" no campo do rock argentino, e esta música é um claro exemplar nesse sentido. E resulta instigante que também seja 
transicional em relação à prosopopeia perceptual que, como veremos, se realiza nele de um modo algo diferente da caracterização que temos feito, já que o ser "percebente" (o mar) adquire participação narrativa, ficando contido na perspectiva do locutor.

A gravação se inicia com um efeito sonoro que pode assemelhar-se a uma tempestade e lembra também um barulho de mar. Logo depois, o começo do canto, acompanhado por violão, se aproxima do folk. Todo esse início parece antecipar uma das composições que, na época, já vão afastando-se dos ritmos estereotipados e "comerciais" da música "para jovens". Porém, logo que entram a bateria e o teclado eletrônico, o ritmo e os arranjos derivam para um típico "lento" de danceteria. A letra é uma pequena crônica sobre o encontro entre um personagem, que é também o "eu" locutor, e uma criança que está entediada e triste por não ter com quem brincar, e nem sequer ter, como outras crianças, um brinquedo. Há uma certa presença de elementos de melodrama, sobretudo uma expectativa de compensação pela virtude: o personagem diz ser pobre e não ter nada a dar para a criança, mas que de qualquer maneira procurará algum brinquedo para ele. Também o fato de aparecer, em discurso direto, a palavra de uma criança é algo que praticamente não terá lugar no rock do país durante muito tempo. Porém, o conjunto da música aponta em outra direção, aproximando-se claramente de lugares e de valorizações que serão centrais no rock argentino em gestação.

Em primeiro lugar, a resolução do conflito desloca a carência material e o próprio mundo infantil para uma relação contemplativa com um objeto da natureza. E o "eu" personagem resulta um "guia" dotado de um saber que pode conduzir a essa solução não convencional. Contudo, o que mais vincula esta composição com a configuração dominante que temos analisado é a articulação das instâncias de pessoa na sequência de olhares encenada, precisamente o tópico onde aparece, também, o tipo de imagem da qual tratamos neste capítulo. $\mathrm{O}$ relato tem como fato deflagrador o olhar da criança para o personagem: "al mirarme, empezó a hablar". O ato de olhar será também o da resolução do conflito e encerramento do relato. E ele se apresenta como uma concatenação: “el niño miró el mar y el mar lo miró a él. Y al rato vi que jugaban los dos”.

Tanto na sintaxe da letra quanto no canto, os dois primeiros olhares da sequência formam uma unidade separada do terceiro. Essa unidade em paralelismo organiza uma passagem de uma direção do olhar (pessoa - coisa) para a outra (coisa - pessoa). Parecenos significativo que, em uma das primeiras composições daquilo que irá aos poucos se constituindo como campo do rock argentino, a figuração do ser percebido pelo entorno 
apareça como uma reorganização interna, relacionada à resolução original de um conflito que é deslocado, dessa maneira, da sua implantação melodramática. O mar para a criança poderia ser visto como uma consolação, um "brinquedo não mercadoria", ou a crônica poderia ainda ativar estereótipos sobre a disposição intrínseca da criança a uma "fantasia interior" que lhe permite encontrar brinquedo em tudo, lugar comum de figurações caritativas. Porém, é mais do que isso o que enseja o encontro narrado, e esse "mais" é dado pelo olhar do mar para a criança e pelo jogo posterior entre ambos, instalando, ainda de um modo muito simples, uma relação ser-entorno que prefigura outro tipo de relato e de preocupação. Essa relação ainda não ocupa a cena toda, ela está contida em um relato que parece de início direcionar-se apenas para uma tradição de narrativas sobre crianças carentes. A criança, que vai experimentar a mudança na sua relação com o entorno não está, neste caso, sozinha em cena. Ela é introduzida por um narrador cuja perspectiva domina o relato todo. Essa perspectiva também fecha a sequência final de olhares: "al rato vi que jugaban los dos", sequência resumida logo depois na sua ordem: "el niño, el mar y yo". É "yo" quem abriu e quem encerra o relato com "nunca me olvidaré". Mas dentro da narração foi encapsulado algo que já sinaliza o interesse por outro tipo de conflito.

\subsection{De volta aos muchachos}

Dentre as primeiras músicas em que encontramos esse tipo de imagem em que algum elemento do entorno "percebe" o ser, há quatro que já abordamos no percurso do Capítulo IV: "Requiem para un hombre feliz", de Los Gatos; "Informe de un día", de Manal; "Canción para los días de la vida", de Luis Alberto Spinetta como solista, e "Muchacho", de Moris, As três primeiras trazem o sol e o amanhecer como elemento “perceptivo". Já fomos apontando naquele capítulo, a partir de esses e de outros casos, que o amanhecer é recorrente na cronografia da mudança crítica, coincidindo com o ponto de inflexão dessa mudança, e que o sol aparece, em várias letras, como fortemente relacionado à transformação. Como já vimos, em "Requiem..." se apresenta um "sol-parasi" que não brilhará para aqueles conformados e de vida sem propósito, como o "hombre feliz" interpelado, que perderam o vínculo com esse astro que os viu nascer. Tínhamos comentado, também, que em "Informe de un día" há um processo oposto e complementar: 
o "eu" náufrago, aquele que em um dia excepcional pode experimentar algo do processo transformador, é esperado pelo amanhecer.

Em "Canción para los días de la vida" encontramos uma figuração do tipo que aqui nos ocupa na passagem "Me pondré las ramas de este sol que me espera para usarme como al aire”. Na análise desta música que fizemos no Capítulo IV já localizamos essa entre um conjunto de imagens, perceptuais ou cinéticas, que põem o ser em uma centralidade completa a respeito do seu entorno. Quase na totalidade da canção a cenografia se enquadra no efeito que atribuímos à prosopopeia perceptual, o espaço todo é uma "cápsula” focalizadora. Também naquele capítulo explicamos que essa música foi pensada para fazer parte de uma "ópera", em cuja trama o mago protagonista, transformado em "ciruja", tinha a missão de achar "alguien a quien sabe que debe mirar hasta el fin". Vimos que, segundo a explicação de Spintetta, essa confluencia "simboliza el encuentro del hombre consigo mismo". Essas palavras, que ali citamos de uma entrevista com o músico, trazem uma imagem que parece expor de um modo que poderíamos chamar "desmetaforizante" o que consideramos a principal propriedade enunciativa da prosopopeia perceptual: a duplicação reflexiva do ser focalizado e a expansão da perspectiva do locutor.

Em "Muchacho", onde, como vimos, o lugar do "tu” é completamente empático, aparece esse tipo de prosopopeia ou reificação, mas de um modo menos concentrado, mediante formulações mais sutis. O canto calmo de Moris vai desenhando, ao longo da música toda, uma das visões mais enaltecidas do ser que vivenciou o deslocamento, do que consegue "sair" sem "escapar". Para um discurso que procura deixar de lado modelos dados, o "muchacho" é, paradoxalmente, quase modelar daquilo que encontra contornos no rock nacional incipiente. Para explicarmos o papel que vemos para a prosopopeia nessa composição, percorreremos as três estrofes de um modo sequencial, diferente, portanto, da abordagem que fizemos na Capítulo IV, onde já apontamos que as três partes começam com a mesma invocação "Muchacho, pronto amanecerá", retomada no encerramento da canção.

Vemos cada uma dessas estrofes como uma fase diferente na articulação entre tempo, pessoa e entorno. Cremos que a primeira estrofe é dominada por um dinamismo no espaço dado por uma cinestesia leve, característica que a diferenciará nitidamente da segunda. É a estrofe que apresenta o cenário urbano, que é trazido, assim, a partir de suaves movimentos que afetam diversas formas de percepção. A primeira perspectiva é a 
do locutor, que somente nesse ponto se explicitará com uma forma pessoal, "me". E ele entra, precisamente, como destinatário individualizado daquilo que a cidade exala, um cheiro de tango antigo. Seu lugar como locutor-intérprete de rock (pensamos aqui na especificação social do locutor segundo GUIMARÃES, 2005) é afetado por esse papel de destinatário de uma cidade animizada, e deslocado assim para um status de depositário de tradições urbanas, de saberes "antigos", em especial o do tango, cujo "cheiro" tem condição de reconhecer. Esse locutor, embora saia logo de foco, não é externo à topografia representada. Ele sente tanto o cheiro quanto o "viento fío y nuevo", que, junto com os "taxis" e "colectivos de paseo" trazem movimento à cena.

A segunda estrofe, em compensação, é uma detenção do tempo e do movimento espacial. Só objetos imóveis entram na descrição, e, como já mencionamos no Capítulo IV, uma instância temporal, o verão, aparece como espaço, como volume, escondida atrás de um prédio. "Estar" é o verbo mais presente na estrofe toda. E há também "saber", outro verbo estativo, integrado na formulação "tu casa está dormida y no sabe de tus noches, de tus noches en la esquina". Nessa segunda estrofe é quando o "muchacho" é propriamente apresentado na sua condição de "náufrago", e isso se faz mediante três objetos a ele relacionados, cama, casa e noites. O último deles é um tempo apropriado pelo ser, "tus noches en la esquina", que será retomado e realçado posteriormente na música.

$\mathrm{Na}$ terceira estrofe, o tempo recupera dinamismo: são descritos um crescer e um voltar. O verso que segue imediatamente ao anúncio de que "pronto amanecerá" é, como nas outras duas, encabeçado por "Y...", mas aqui é mais longo e, no canto, a voz aumenta nitidamente seu volume. Aparece nele uma figuração do tipo que estamos indagando, quase oposta à que aparece em "Informe de um día": "el día no espera a nadie". Porém, a temporalidade do "muchacho" é, em certo modo, diferenciada do que abrange o totalizador negativo "nadie". O dia não parece tão implacável com ele. O dia é uma criança que, no seu crescimento, prepara o "atardecer", quando o ciclo do "muchacho" recomeçará. E esse movimento do dia que "crece como um niño" é imediatamente seguido pelo anúncio de uma outra mudança: o retorno do verão, quando a apropriação do tempo pelo "muchacho" alcançará seu ponto máximo. Tanto o "eu" locutor quanto o "tu" garoto são, nesta composição de Moris, detentores de saberes. Saberes sobre o "sair" que transforma a existência, sobre a solidão, sobre o ciclo do tempo, sobre a cidade e sobre a música. E, em vários pontos da canção, elementos abrangentes do entorno espaço- 
temporal, tais como a cidade ou o dia aparecem em relação par a par com o ser. Esse "pareio" não é a fonte do saber, é apenas parte dele.

\subsection{Vírgenes de sí}

Trataremos, neste item, de algumas composições de Javier Martínez, gravadas com o trio Manal, que têm em comum, além da figuração que estamos indagando, a presença de figuras femininas como objeto de desejo e/ou de amor, o que nos permitirá voltar sobre a tópico iniciado no Capítulo III, sobre os modos de representar esse tipo de vínculo.

A primeira que veremos é “Avenida Rivadavia”. Essa música é também uma das que, no repertório dessa banda, mencionam lugares específicos da cidade de Buenos Aires ou das suas redondezas. Essas ocorrências têm sido levantadas, na construção da história do campo pela crítica e inclusive em alguns trabalhos de maior especialização, para sustentar um suposto arraigo poético do rock argentino, em especial de alguns dos seus compositores pioneiros, na territorialidade portenha. No capítulo seguinte abordaremos com mais precisão a relação do "progressivo" com o bairro e com os territórios urbanos, mas queremos antecipar que não nos identificamos com essas leituras. Concordamos, nesse ponto, com Pujol (2007b, p 16) em que os pioneiros se postulavam "para ser la voz de una generación, no de un país o una región”. Cremos que a cidade, o urbano, como habitat ou paisagem foi sim, como já explicamos na seção anterior ao analisar "Final", de Spinetta, cenário e ainda tópico de conflito no primeiro rock argentino. Mas algo diferente é que uma determinada cidade e seus bairros apareçam, como aconteceu no tango, como topografia inseparável da constituição de narrativas, entrelaçada com a própria construção das instâncias de pessoa nos seus diversos níveis. Concordamos, a respeito, com Monteleone (1993, p 405): “El espacio urbano no aparece en el rock argentino como zona del pretérito -ese barrio plateado por la luna que en la letra del tango se afantasma hasta volverse el blanco quieto de unos ojos muertos." 95

\footnotetext{
${ }^{95}$ Com "barrio plateado por la luna" Monteleone alude ao começo do tango "Melodía de arrabal", de Carlos Gardel e Alfredo Le Pera.
} 
Nesta música, segundo descreve o crítico Claudio Kleiman (2007), o arranjo combina elementos de rock e blues com um tratamento rítmico próprio do jazz. Embora haja letra, a escuta faz perceber um protagonismo instrumental muito maior que nas composições mais relacionadas à forma canção via o folk ou a balada. O próprio canto, em alto volume, se integra aos instrumentos na performance, em uma música em que a dimensão sonora (voz incluída) pareceria se impor sobre a verbal. Mesmo assim, a organização sequencial da letra guarda muita coerência, como veremos, com a evolução rítmica.

Há duas breves partes, na composição, que se diferenciam apenas no seu início, continuando depois da mesma maneira. Esse início introduz uma situação na rua que poderia preceder uma narração, e o que lhe segue é um esboço narrativo, em forma de pergunta, igual nas duas partes. Depois de terminar o canto da segunda parte, segue um instrumental de 30 segundos, e depois há outro bloco de canto que reúne as duas partes como uma só. O canto de cada parte contém, por sua vez, repetição imediata de cada um dos seus trechos internos, diferenciados entre si por nítidas mudanças no ritmo. No seguinte quadro, cada linha corresponde a um trecho que se repete:

$1^{\mathrm{a}}$ parte

\begin{tabular}{|l|l|}
\hline $\begin{array}{l}\text { Caminamos una calle sin hablar. } \\
\text { Avenida Rivadavia. }\end{array}$ & 2 vezes \\
\hline Y pensé & 2 vezes \\
\hline $\begin{array}{l}\text { ¿Cuándo subiste a mi tren, mujer, } \\
\text { que yo no te vi? }\end{array}$ & 2 vezes \\
\hline
\end{tabular}

$2^{\mathrm{a}}$ parte

\begin{tabular}{|l|l|}
\hline $\begin{array}{l}\text { La mañana incoherente me sonrió. } \\
\text { Una burla que volaba se escapó. }\end{array}$ & 2 vezes \\
\hline Y pensé & 2 vezes \\
\hline $\begin{array}{l}\text { ¿Cuándo subiste a mi tren, mujer, } \\
\text { que yo no te vi? }\end{array}$ & 2 vezes \\
\hline
\end{tabular}


As sílabas de dois finais de verso se prolongam: "pensée" e "vii", precisamente os que correspondem aos processos que experimenta o ser representado pela voz e pela $1^{\mathrm{a}}$ pessoa. "No te vi" tem ainda uma repetição interna adicional. O trecho "Y pensé", apesar da sua brevidade, ocupa um lugar de destaque por corresponder, ele só, a um dos momentos rítmicos, e é também a passagem do início descritivo para o assunto que parece motivar a narração. O ponto em que a voz de Alejandro Medina, potente ao longo da música toda, adquire mais volume é na interrogação e invocação “¿Cuándo subiste a mi tren, mujer?" Cremos que essa distribuição das repetições no canto, dos alongamentos e do volume da voz na interpretação, bem como dos lugares de passagem de um ritmo a outro vão configurando um lugar para a perspectiva do locutor e personagem que tentaremos explicar focalizando, agora, a letra.

A cenografia de rua é instalada do início, com uma 1" pessoa plural, "caminamos", que logo será reduzida ao singular "pensé". Segue o nome da rua, que é também o da música, cantado com a duração de um verso, para um cenário que não será retomado como tal. O "fato" que se acena narrar não chega a ganhar dimensão de relato. O âmbito já não é a rua, mas o "pensamento" do ser, e o que a voz traz seria uma marca ali deixada pelo que foi experimentado. Esse acontecido fica como elipse, cujos contornos são dados pela interrogação. Contornos que deixam ver principalmente um desejo, audível na vocalização realçada de "mujer”, em um átomo de narratividade que pode expandir-se a uma ocasião fugaz de atração ou à lembrança de um relacionamento. A possível paráfrase, procurada ou não pelos autores, com a unidade idiomática "perder el tren" orienta mais ainda a interrogação para o autorreproche: era o meu trem, eu estava nele e não te vi. $\mathrm{O}$ modo como se insere a prosopopeia no início da segunda estrofe retoma essa expectativa quebrada: a manhã sorri, e ela é incoerente por fazê-lo. A esse sorriso segue logo a burla, precisamente uma manifestação que é também da ordem do rir, mas oposta no eixo da empatia. O locutor, como personagem masculino posto em cena, é o foco direto da primeira, mas também, de algum modo, da segunda: uma possível burla, de outros ou de si mesmo, "voava" e encontrou seu destino.

Dessa maneira, cremos que a figuração sobre a manhã direcionando-se ao ser se integra em uma série de passos que, numa música que expõe o desejo sexual e amoroso, apresentam esse encontro / desencontro com um nítido polo na percepção e na atividade imaginativa do ser, cujo movimento (caminhando ou feito trem) é o princípio que 
constitui a topografia. O primeiro desses passos é o que já mencionamos, em direção ao "pensamento" íntimo, outro é a subida da mulher "a mi tren".

Encontramos uma polaridade semelhante em uma música também de Javier Martínez em que a mulher não é alguém sem individualização, mas o tópico de um canto completamente dedicado a ela, "Paula", do segundo disco de Manal (El León, gravado em 1970 e publicado em 1971). Transcrevemos a letra com grifos nossos:

Paula, no hay tiempo de más. / Paula, otra vez no será. / El día es un día como hoy, / un día que no vuelve nunca más. / Un fantasma de mí quedará / incrustado en el gris de la ciudad / si antes no encuentro tu rastro de luz, / oh, Paula, / en el día de hoy / en la ciudad. / Paula, quiero ver dónde estás. / Paula, una vez nada más. / Tuviste un destino especial, / viniste a mi mente, nada más. / Pero ahora te estoy esperando. / Quiero verte también caminando / conmigo, con autos, con subtes y luz de mercurio. / En el día de hoy, en la ciudad.

A devoção que leva a enunciar uma dependência quase vital em relação à amada não impede apontar como "destino" desta ter chegado "a mi mente". A observação dessa letra nos serve de passagem para a última composição de Javier Martínez que observaremos neste percurso, cuja letra apresenta várias figurações na linha da prosopopeia que nos ocupa. Trata-se de "Si no hablo de mí", também gravada em El León, seguindo no disco imediatamente a "Paula". Nela também aparece essa personagem, mas já não como interlocutora, e, como veremos, sua integração na perspectiva autorreflexiva do locutor se aprofunda.

Sobre "Si no hablo de mí", Claudio Gabis, que fora o guitarrista da banda, fez recentemente um comentário interessante no seu canal de Youtube. A música estaría conectada "en mi opinión, con 'Porque hoy nací' (del primer disco de nuestra banda) y fusiona elementos de existencialismo, psicodelia y ciencia ficción”. Em que pese à pouca compatibilidade entre os termos da "fusão" proposta por Gabis, a menção do existencialismo indica algo da percepção que foi sendo estabelecida em torno do campo do rock argentino nos seus inícios, e não nos parece casual que surja para qualificar uma música que registra muito do tipo de mudança crítica que fomos caracterizando no Capítulo IV. No entanto, o que mais interessa para nosso trabalho é a vinculação que o músico estabelece com "Porque hoy nací", logo o ponto pelo qual decidimos começar nosso percurso naquele outro capítulo. 
As duas canções têm semelhanças no plano musical e na dimensão verbal. Também se trata de um ritmo de blues, com outros instrumentos ${ }^{96}$ mas com o mesmo tipo de canto arrastado (sobretudo no início, quando canta somente Javier Martínez), e incluso a melodia é próxima em algumas partes. O canto começa com uma interrogação retórica que retoma o título desdobrando a voz em apresentador e apresentado: "Si no hablo de mí, ¿de quién voy a hablar?" O desdobramento é congruente com o estado de "ser outro homem" que imediatamente se anuncia com o acréscimo de uma marca de resultado presente, "ya". Um traço central da crise transformadora aparece na descrição do renascido: a reiteração gozosa de estar sozinho, com imagens de despojo de todo o anterior, na ordem da "pura solidão consigo" que vimos, por exemplo, na análise de "Pipo la serpiente", de Miguel Abuelo. O deserto e, depois, o universo são topografias congruentes com essa premissa. Há uma diferença que nos parece pertinente apontar em relação a "Porque hoy nací" e a boa parte das obras do período em que se tematiza a mudança no ser: o entorno aqui está explicitamente composto sem o sol e sem sequer sua espera. Não nos parece, no entanto, que esse traço aproxime esta composição ao processo de desregularização parcial que no Capítulo IX explicaremos como de "consternação", já que o sol ou sua ausência não aparecem relacionados aos sentidos de perda que caracterizam essa outra série.

Depois da localização no "desierto sin sol", seguem duas imagens mediante as quais se dá a passagem entre esse ambiente e o "universo". Essas imagens vão operando uma inversão da relação ser-entorno, subordinando este à perspectiva daquele: as naves eram "vírgenes de mí"; a galáxia "todavia no me toca”. Nessa galáxia a mulher amada espera pelo homem em deslocamento, e dela, Paula, é dito que imortal, o que a coloca num plano diferente em relação a como aparecia na música que leva seu nome. É fortemente intensificada a representação do amor como mediado por um episódio introspectivo, já que o renascimento-viagem-nova solidão do locutor e personagem foi o que trouxe a nova condição de Paula. Ela fica num ponto intermediário entre duas figurações femininas que se reiteram no rock argentino dos primeiros tempos, e voltam recorrentemente ao longo de toda sua existência como campo. Por uma parte, a mulher amada como objeto da criatividade do homem encarnado na voz do locutor, lugar que vemos em "Natural”, de Tanguito ("Me gusta verte en las mañanas, ponerte de colores"), ou em "Muchacha, ojos de papel”, de Spinetta, que já discutimos no capítulo anterior.

\footnotetext{
${ }^{96}$ Em "Porque hoy nací" não há bateria nem baixo, só órgão Hammond e guitarra.
} 
Mas, nesta música, a imagem de Paula se aproxima também de outras fora da ordem do mundano ou do espaço das relações pessoais como universo de referência. Figuras femininas como as que aparecem em "Ella también", de Spinetta ${ }^{97}$ ou em "La princesa dorada", de Tanguito e Pipo Lernoud, quase místicas, mas que guardam algum tipo de vínculo pessoal com o ser ou até se deslocam na sua direção. O percurso de Paula é, nesse aspecto, oposto: do mundo urbano e cotidiano à galáxia atemporal, em ambos os casos trazida à cena como parte de um deslocamento do personagem em que o locutor se identifica.

Depois de um interregno instrumental, a letra focaliza um passado em que o amor parecia consistir em escrever ou falar dele. A imagem a respeito é imprecisa, mas a representação espacial dessa anterioridade como "pasillo del tempo" é congruente com a narrativa de deslocamento que domina a canção, na qual o presente é o lugar atingido da novidade. A imagem final é um dos casos mais peculiares neste tipo de prosopopeia que estamos analisando: o elemento do entorno que aguarda pelo ser é o mais abrangente possível, e determinado como próprio; "mi universo me está esperando". Essa determinação é a expressão mais nítida do efeito que, como explicamos antes, consideramos que esta figuração tende a imprimir no jogo de perspectivas e saberes: reforço reflexivo do ser na cenografia e do processo de encenação na voz. Assim, o canto se encerra anunciando que o corpo de interlocutores compartilha um saber sobre esse processo, no caso, sobre o que "custa" a saída e o despojo que pode conduzir ao encontro superador consigo.

\subsection{Do automático ao refúgio}

Outra composição na qual encontramos uma figuração de um objeto do entorno desta vez, gotas de chuva- percebendo o ser é "Detrás del vidrio", da banda Vox Dei, gravada em 1972 no LP Jeremías pies de plomo. Essa banda, alguns de cujos trabalhos abordaremos no Capítulo IX, mostrou de modo geral pouca originalidade no campo do rock argentino dos primeiros tempos. A observação da música que aqui trazemos é interessante por revelar já alguns traços de automatização na sua materialidade verbal.

\footnotetext{
${ }^{97}$ Música gravada só em 1982, no disco “Kamikaze”, mas executada ao vivo pelo menos desde o início dos 70 .
} 
Apesar de ser relativamente recente, já que de 1965 a 1972 há apenas sete anos, o campo já consolidou, nessa altura, fórmulas e lugares comuns.

A automatização de alguns tópicos tende, em primeiro lugar, a uma distribuição esquemática entre o eufórico e o disfórico que ocasiona simplificação e perda de densidade. A solidão, por exemplo, relacionada a sentidos de incomunicação, mas também, quando espeficidada como "interna" ou "verdadeira", aparece como parte de um despojo de todo engano para atingir a transformação procurada, como vimos já em vários exemplos de Moris, Miguel Abuelo, Manal e Almendra. Como esse, outros tópicos são aplainados em "Detrás del vidrio", abrindo caminho a dizeres relacionados, pela sua orientação argumentativa, à posição de sujeito tecnocrático que dava base ao disciplinamento juvenil pelo imperativo de dinamismo e competitividade. Com efeito, o aproveitamento do presente, o elogio do não perder tempo e seguir metas claras se percebe na imagem de jovem conformado e progressista, embora "naturalmente" inquieto e rebelde que a indústria cultural promove na época, como também a indústria da moda e o mercado de trabalho. Mesmo não sendo essa, evidentemente, a opção de músicos como os de Vox Dei, e mesmo estando eles e seu público longe desse modelo de jovem, em várias das suas músicas mais famosas, como "Total qué" ou "Presente (el momento en que estás)"98, a exaltação da conquista, do avanço permanente e da realização da própria vontade apontam nessa direção.

"Detrás del vidrio" foi gravada como duas músicas em sequência, especificadas como I e II. Nas duas, uma voz em $1^{\text {a }}$ pessoa se insere como personagem em uma cenografia de isolamento. A separação do mundo está dada por encontrar-se precisamente "detrás del vidrio". Na parte I é descrito o isolamento, retomado na parte II, quando "Dos inviernos más ya han passado" e o ser anuncia sua disposição a sair. A melodia e o ritmo na primeira parte são lentos, e o canto parece quase um recitado, com alguns toques de blues. Na segunda parte, em compensação, todos os componentes sonoros adquirem velocidade, em um rock cujo canto lembra, por momentos, "Paint it black", dos Rolling Stones. Na letra se produz uma polaridade análoga, caracterizada pelo modo como o locutor fala de si mesmo. Na primeira parte sua perspectiva se desdobra, já que, como observando-se de um lugar de maior percepção, anuncia "creo ser feliz pero no me doy cuenta porque solo pienso que estoy hoy solo". Há uma certa lacuna acerca daquilo do

\footnotetext{
98 Talvez uma das mais claras evidências da volubilidade de "Presente..." seja o fato de ser, ainda hoje,
} música obrigada de formaturas. 
qual não se dá conta, mas as gotas da chuva no vidro, elemento que aqui participa da prosopopeia, coincidem com o lugar de mais saber, já que, além de vê-lo, informam sobre algo do que há para além do vidro. Na segunda parte, o desdobramento continua, mas de outra maneira, como um diálogo consigo mesmo, com interrogações e negações polêmicas. Se na retórica do rock no período há, como já vimos em vários casos, uma axiologização positiva do "verdadeiro", aqui o elogio é da "realidade" à qual o ser se furtaria por estar isolado. Cremos que essa diferença resulta precisamente do aplainamento por automatização ao qual nos referimos. Em um trabalho anterior (Fanjul, 2010), mostramos que essa celebração do "real" aparece, nos anos 90, nas formas mais repetitivas e menos elaboradas da vertente "metálica" do rock argentino. Neste caso, a voz chega a afirmar que "estar en el umbral no es estar en vida", e aparece inclusive, como objetivo, o aproveitamento de "el tiempo que el destino da".

A última música da qual trataremos neste percurso é "Pascual tal cual", da banda Color Humano, conduzida por Edelmiro Molinari depois da separação de Almendra em 1970. A composição apareceu no segundo disco da banda, em 1973. Cremos que esta música participa de uma série de acontecimentos discursivos na regularização discursiva do rock argentino que vão produzindo uma desregulação parcial em relação à condensação que temos descrito até agora. Referimo-nos ao que no Capítulo IX explicaremos amplamente como "consternação" e que, como veremos, mais do que um período é uma tendência que coexistirá contraditoriamente com o que já vinha sendo consolidado. O motivo principal pelo qual relacionamos este rock-canção de Color Humano a essa nova condensação é que o espaço de chegada, depois da mudança crítica, depois da ruptura, tem traços de refúgio, não de risco, nem de despojo ou desafio inexplorado. A voz que interpela Pascual propõe a ele uma ida para o "campo", onde "ya no hay por qué andar cubierto", e anuncia que uma tempestade o escudará.

A relação entre quem percebe e quem é percebido é, nesta canção, entre a chuva e Pascual, uma $2^{a}$ pessoa a quem canta a voz, que por sua vez se localiza na cenografia como alguém que mora no campo. Já influenciada pelo rock sinfônico, a composição tem momentos claramente diferenciados. Em um encarte que classifica as músicas entre "rock" e "blues", esta aparece como "rock", e efetivamente, os primeiros três minutos são de um rock compacto com articulada marcação de bateria e baixo. O mesmo ritmo volta com maior potência nos 30 segundos finais, mas no meio há um fragmento de cadência lenta e notas prolongadas, com protagonismo da guitarra elétrica y um ritmo mais calmo. 
Todo o início da música é uma série de invocações a Pascual para que vá a um espaço onde há "carretas", um "rancho" e o pôr do sol, objetos da paisagem rural, mas com toques bem alheios a essa tradição, já que o rancho é de "barro azul" e ali encontrará a "locura total" "99. A segunda estrofe se encerra com uma afirmação de tom proverbial, que contém de um modo particular a figuração da mudança como novo nascimento, aludindo também a atividade de cantar: "Vértigos de pinos y carretas pueden al nacer cambiar tu canto". É no fragmento intermediário, enquanto a guitarra soa doce e tênue, que a voz de Molinari, quase declamando, anuncia o encontro entre Pascual e a tempestade: "Una tormenta siempre te escudará. Sal a la lluvia que viene por ti." A prosopopeia abre caminho a um encerramento com imagens que coadunam o "eu" e o "tu" em um intercâmbio de espaços determinados a partir de si. "mis noches", "el humo de tu soledad".

\subsection{Si es que el sol te ve}

Há uma canção de Almendra que permaneceu como inédita até que, recentemente, começou a circular sua gravação ao vivo, resgatada de um show de $1969^{100}$, pouco anterior à publicação do LP que analisamos no capítulo anterior. "Chocolate", título que aludia ao nome de um cachorro, teve música de Spinetta e a letra foi composta entre ele e sua companheira daquele tempo, Cristina Bustamante. Encerraremos este capítulo com uma breve observação do funcionamento da prosopopeia nessa canção, para introduzir com ela uma primeira conclusão sobre o modo como esse tipo de figuração que nos ocupou se articula nas configurações de objetos, cenografia e instâncias de pessoa nessa primeira regularização que foi consolidando-se no rock argentino.

A voz canta a uma $2^{\mathrm{a}}$ pessoa, à qual direciona algumas sugestões e desejos, à vez que anuncia a passagem da noite para o dia. O sol aparece, no início e no final da canção, como condição ou causa de uma mudança no ser. Primeiro, que o sol "veja" a pessoa pode ocasionar que ela não se afaste de um lugar agradável, a casa com cheiro de chá.

\footnotetext{
${ }^{99} \mathrm{Na}$ prosódia do canto, esse grupo nominal é clivado, ficando a palavra "total" claramente separada como um grito autônomo, que lembra a interjeição empregada na gíria portenha da época para qualificar algo como superlativamente positivo: "Total!".

${ }^{100}$ É essa a gravação que aparece no CD dos Anexos, e foi com base nela que estabelecemos a transcrição da letra. Na nossa escuta, ela tem diferenças com a que foi publicada em Berti (2014, p 208).
} 
Finalmente, é o sol quem pode fazer feliz a pessoa e tirar a solidão que está "pendurada" dela. Assim, a pessoa recuperará as cores e contestará a voz da sua própria tristeza.

Postulamos em 1.4 que, no jogo enunciativo, a prosopopeia/reificação traz como efeitos o reforço ostensivo -como insistência da sua individualização- do ser "percebido", concomitante com a expansão da perspectiva de um enunciador universal. Cremos que os casos que mostramos na primeira fase do rock argentino nos permitem postular que, na regularização discursiva que tentamos fundamentar nesta tese, esse tipo de figuração foi, por um lado, harmônica com o duplo processo de distanciamento crítico e reaproximação sobre si que aparece como passagem necessária na transformação demandada. E, por outra parte, na grande maioria das suas aparições, fica integrada na cronografia do amanhecer ou da chegada do sol como momento de inflexão. No capítulo seguinte, a partir da análise de uma composição e do encarte de um LP, indagaremos com mais aprofundamento um outro aspecto que iniciamos aqui em torno de "Muchacho": como essa figuração se articula com os lugares de saber e com os percursos de vida representados. Esse capítulo será, também, a ocasião de indagar algumas filiações e distanciamentos entre o "progressivo" argentino e gêneros anteriores de tradição popular. 


\section{Capítulo VII \\ Tango flutuando e increpação em cena}

(Segundo caso)

A canção "Pato trabaja en una carnicería", de Moris, que segundo Pujol (2015, p 21) tem "ecos inocultables de Bob Dylan", mostra uma passagem com o tipo de prosopopeia que indagamos no capítulo anterior. Essa música, composta provavelmente entre 1967 e 1969, foi incluída na segunda edição do primeiro LP de Moris, Treinta minutos de vida (1970). O disco apresenta uma significativa unidade, já que quase todas as canções nele gravadas, salvo duas (a já abordada "De nada sirve" e "Esto va para atrás") são relatos de vida, em vários casos de aprendizagem, com a prática artística como assunto incluído em maior ou menor medida. Não casualmente o nome do LP sinaliza a reunião de fragmentos de vida nos seus aproximados 30 minutos de duração.

Antes de abordarmos a música que aqui nos ocupará, vale a pena nos determos sobre alguns componentes do encarte original do disco. A capa semelha um tipo de caderno escolar empregado na Argentina durante várias décadas, forrado no que se chamava "papel araña” azul, com uma etiqueta branca no canto superior direito, na qual se lê, com grafia de escrita escolar, o nome do cantor e do disco, e a nota "grabado en 1969”. No avesso, depois da lista de músicas, começa um texto que continua no interior do LP, que simula folhas pautadas de caderno. O texto completo é o que segue:

Son las once y media de la noche y escucho en el aire una canción del conjunto Creedence Clearwater Revival ${ }^{101}$ y suena con la naturalidad de un tango antiguo flotando sobre la ciudad..

Mañana tengo un recital y estoy un poco afónico y con gripe. Sin embargo el LP está listo y la voz está fijada para siempre en la cinta de grabación y han sido unos cuantos años de cantar, vagar, componer y dar la cara a lo que me ha tocado vivir.

Ahora que miro la lista de los temas, los veo como pedazos de un rompecabezas incompleto, que soy yo mismo. Y sin embargo no puedo detenerme en esta música. Ya estoy viajando con mi

${ }^{101}$ Banda estadunidense de country-rock, formada em 1967 a partir de músicos que já tocavam do início da década. 
mente hacia lugares que todavía no sé qué o cómo son. Pero voy a necesitar otros materiales, otros sonidos, otras palabras y hasta ganas.

Y aquí están, fieles al tiempo, separadas por algunos silencios de púa, las cosas maravillosas y malditas que he vivido y sentido en esta minúscula era de mi existir.

Depois do texto, também representado com caligrafia escolar, seguem comentários breves sobre cinco das composições. Essa apresentação do disco que acabamos de transcrever instala uma cenografia de intimidade solitária, como se a gravação que deixou o LP "listo" e com a voz "fijada para siempre en la cinta" tivesse acontecido no isolamento. A situação de escuta que inicia a digressão é particularmente interessante pelo ordenamento temporal das tradições invocadas nela. A música de Creedence é reterritorializada como um tango que flutua sobre a cidade. Mas ela está soando no exato presente, dado pela especificação da hora, enquanto a saudação ao tango não deixa de localizá-lo numa temporalidade passada, por sinal, com a mesma denominação que vimos em "Muchacho": "tango antiguo". A vinculação da obra com o percurso vital se anuncia em uma declaração que é mais um claro exemplo do direcionamento a si que, no Capítulo IV, começamos a localizar como ponto de passagem da mudança crítica do ser: "pedazos de um rompecabezas incompleto, que soy yo mismo". O mesmo tópico é retomado no final do excerto, com o fechamento "esta minúscula era de mi existir", antítese na qual a qualificação de "minúscula" apenas morigera a centralidade que a entidade pessoal ganha ao ser posta como medida de um recorte temporal, a "era".

Em algumas das canções do disco se representa um passado idílico identificado com a infância. "Pato trabaja en uma carniceira" inclui, na sua primeira estrofe, a que consideramos a mais nítida e condensada formulação dessa visão idílica, e o faz juntamente com a representação do sol percebendo, olhando o cenário e as personagens:

Eran los días, los días de oro.

Y el sol miraba sin preguntar.

No mesmo lugar (último verso) da segunda estrofe, referida à adolescência ("novias de flores, primeiros cigarrillos"), o sol é novamente trazido para a cenografia: 
"y las mañanas del sol aquel”. Vamos nos deter particularmente nesta música, mais demoradamente do que nas do capítulo anterior, por três motivos. Por uma parte, consideramos que, nela, várias das problemáticas que abordamos no Capítulo IV, tais como os modelos e anti-modelos que a regularização primeira do rock argentino tende a produzir, o lugar eufórico para a "verdade", ou a representação da atividade artística, aparecem juntamente com uma articulação das instâncias de pessoa na qual a prosopopeia cumpre, como veremos, um papel. Por outro lado, porque ela evidencia filiações temáticas e enunciativas com uma linha específica do tango que, aparentemente, fazem dela uma peça única no rock argentino daquela época. A respeito, tentaremos mostrar que se trata apenas do caso mais extremo, porém, que essa mesma filiação se percebe, mais diluída, em um leque mais amplo de composições. Por último, e também em relação ao tango, a análise de "Pato trabaja..." e as remissões a outras composições que iremos fazendo no seu desenvolvimento nos permitirão fundamentar que, para além da ressonância de determinadas figuras e modos de enunciar, a exploração dessas semelhanças acaba por mostrar que o tango-canção e o primeiro rock argentino se distanciam fortemente nas posições de sujeito que os atravessam em relação à conflitividade social.

\section{O palco do escárnio}

O modo como se representa a interlocução nesta canção é peculiar. O homem apelidado "Pato", referido no título e mencionado colateralmente na segunda estrofe, não é nem o locutor personagem, nem o "tu" interpelado ao longo da música toda. Apesar da expectativa que o título cria, Pato parece ser apenas alguém que fazia parte das amizades do passado evocado e que, no presente a partir do qual se fala, trabalha em um açougue. Nada mais é dito sobre ele na canção.

Os protagonistas da história narrada não têm nome, apenas “yo" e "vos". O locutor posto em cena na voz de Moris se identifica como alguém que provém de um bairro popular, e interpela duramente um igual que cresceu no mesmo espaço, que pertenceu ao seu círculo de amizades e que leva, como jovem adulto, uma vida egoísta. Antes de descrever a "idade de ouro" já antecipa aquilo que dará lugar ao conflito, sintetizado em um trocadilho "lo tuyo es mío y lo mío es mío", que na "não compreensão" atribuída à 
infância era visto como "piada". O único aspecto de "aprendizagem" que mostra o relato é essa reflexão inicial, já que, depois, o percurso de vida não indica qualquer resolução para a perspectiva empática do "eu”, ele apenas examina a degradação do anti-modelo.

No Capítulo IV, quando analisamos o direcionamento para $2^{\mathrm{a}}$ pessoa em "Requiem para um hombre feliz", antecipamos que esse modo específico, disfórico, de pôr em cena um "tu" era relativamente recorrente em alguns dos pioneiros. Comentamos, também, que ele se registrava em uma vertente do tango das décadas de 20 e 30. Ampliaremos essa referência aqui para tratar de "Pato trabaja..." e das marcas de algumas formas de dramatização que vemos nessa música.

Analisando os modos como o personagem do "compadrito" 102 foi sendo articulado enunciativamente no tango, Menezes (2012), encontra uma primeira série de tangos "cupleteros", concebidos para fazerem parte de representações em gêneros dramáticos de tradição popular, nos quais o "compadrito" se apresenta a si mesmo em um cantar elogioso e exultante, articulado na primeira pessoa; por exemplo, "El porteñito", de Angel Villoldo, ou "Matasano", de Pascual Contursi e Francisco Canaro. Na medida em que o “compadrito" começa a ser deslocado das valorizações eufóricas, como efeito, no gênero, do que Menezes interpreta como processos de disciplinamento, esse tipo social vai passando a ocupar o lugar da segunda pessoa, o de um ser interpelado em cena por um locutor cuja função se assemelha ao apresentador no espetáculo popular. Uma transição seria o tango "Patotero" (1922), de Manuel Jovés e Manuel Romero que foi, precisamente, parte de um sainete ${ }^{103}$. Nele se ouve, no início e no final, o canto do "apresentador", que fala ao "patotero" (o "tu”), sendo o resto da música o canto desse que começa sendo interpelado e passa a falar na $1^{\mathrm{a}}$ pessoa $^{104}$. Em outros tangos que

\footnotetext{
$102 \mathrm{Na}$ Argentina, o termo "compadrito" começou designando tipos sociais entre o rural e o urbano, marginalizados pelos diferentes caminhos que foi tomando a organização socioeconômica, e dedicados a atividades como o jogo de apostas, ser guarda-costas de caudilhos políticos, ou o proxenetismo. Embora tenham existidos todas essas ocupações, o "compadrito" tende mais a ser uma figura da poética do tango e de alguns gêneros literários. (CRUZ, 2011). Muitas vezes são atribuídas a ele, como ao "compadre" ou ao "orillero" -figuras mais ligadas à tradição pré-imigratória- qualiidades como honra, coragem e autenticidade, e habilidade na música e na dança. Também, contraditoriamente, a figura do compadrito é admoestada pelo seu pouco apego ao trabalho e à disciplina. Menezes (2012) analisa comparativamente a construção, como lugar de dizer e/ou como objeto de discurso, do "compadrito" no tango e do "malandro" no samba durante as décadas de 1920 e 1930.

$103 \mathrm{O}$ sainete, na Espanha, era uma peça teatral menor, de caráter humorístico, pelo geral representada durante os intervalos. Em Buenos Aires, nos finais do século XIX e começos do XX, o sainete denomina uma peça que pode se apresentar por separado, pelo geral em espaços de presença popular, como o "circo criollo", e que inclui quadros musicais. O sainete portenho evolui para algumas peças de autor, que chegam a ser representadas em teatros.

${ }^{104} \mathrm{O}$ que não impede, é claro, que na maioria das gravações o mesmo intérprete cante a totalidade.
} 
apresentam o "compadrito" de um modo mais disfórico ele não tem voz, é apenas o interpelado; exemplos são "Compadrón" (1928), de Luis Visca e Enrique Cadícamo, ou "Mala entraña", do mesmo ano, de Enrique Maciel e Celedonio Flores. Uma das principais "cobranças" direcionada à personagem é sua falta de autenticidade, caracterizada, dentre outros traços, por ter abandonado valores próprios da sua condição ou do bairro, que tinha, em relação a ele, determinadas expectativas. Um tipo análogo de interpelação aparece nos tangos que põem em cena o que Garramuño (2009, p 127) denomina "milonguitas", moças que, por ambição ou por frivolidade, deixam a vida pacata do bairro e caem em um tipo de "perdição" moral ("Flor de fango", de Pascual Contursi, "Milonguita", de Enrique Delfino e Samuel Linning, "Mano a mano", de Carlos Gardel e Celedonio Flores, dentre muitos exemplos). Também se registra, veiculando similar desprezo pelo fingimento, em tangos que trazem personagens masculinos simplesmente farsantes, como "Fanfarrón" (1928) de Luis Visca e Enrique Cadícamo, ou "Niño bien" (1928), de Juan Antonio Collazo, Víctor Soliño e Roberto Fontaina. Mesmo tendo o tango se distanciado, devido às formas de reprodução e circulação, da coexistência com as formas dramáticas de tradição popular, como o "cuplé" ou o sainete, essa forma de interpelação permaneceu nele.

Em "Pato trabaja en uma carniceira", os assuntos postos em jogo na desmoralização do personagem são, como logo retomaremos, diferentes daqueles do tango, mas a articulação enunciativa é semelhante à dos tangos de increpação: um locutorapresentador e um interpelado posto em cena para exposição exemplar de um anitimodelo, matizada pela ironia. O desenvolvimento musical que foi dando lugar ao rock argentino não experimentou a convivência direta que o tango teve com gêneros dramáticos populares, já que estes pouco subsistiam como tais na década de 1960, tendo sido absorvidos pela mídia ou pela indústria cultural (STEIMBERG, 1998). Porém, isso não impede considerar certas filiações indiretas. Em primeiro lugar, por meio da própria tradição tangueira. Em segundo lugar, porque a absorção desses gêneros pela mídia e pelo espetáculo industrializado não foi uma desaparição: suas configurações enunciativas, seus tópicos, a implantação social das vozes que eles punham em cena subsistiram, afetados pela inserção nos novos modos de reprodução e circulação. Como aponta Martin-Barbero (2008, p 238-241), o "radioteatro", tanto nas suas formas cômicas quanto nas melodramáticas, incorporou fortemente esses elementos, e algo semelhante aconteceu com o teatro de revistas. E, em terceiro lugar, porque como parte da mesma renovação 
cultural que dá lugar ao rock argentino na década de 1960, há, especialmente em Buenos Aires, novas práticas que reinstalam a combinação, no mesmo palco, de dramatização breve e canção. O movimento denominado "Nueva Canción Argentina" (COLOMBA, p 160), no qual podemos localizar artistas como Nacha Guevara, Alberto Favero, Jorge Schussheim ou Carlos Waxemberg, desenvolve uma linha de canções com apelo humorístico, apresentadas em bares e espaços de café-concert $^{105}$ incluindo diversos elementos de concepção cênica. Independentemente das idades diversas dos seus protagonistas, não foi uma corrente identificada com a música "jovem" ou "para jovens". Pujol (2002, p 274-275) aponta que esses artistas, de modo geral, encontravam inspiração no music-hall, mas vale ter presente que essa modalidade europeia de espetáculo tem raízes muito semelhantes às dos gêneros de tradição popular que acompanharam as primeiras décadas do tango, e que tanto as modulações do sainete quanto as das formas humorísticas do tango são reconhecíveis, por momentos, na performance desses cantores. Quase não há registros de compartilhamento de espaços de atuação entre intérpretes da "Nueva Canción" e o rock argentino inicial ${ }^{106}$, mas tudo parece indicar que ela não era em absoluto desconhecida para os jovens roqueiros, que podem ter sido parte do seu público, já que a entrada da "Nueva Canción" nas salas de espetáculo de um circuito amplo e inclusive na mídia foi relativamente rápida. O já mencionado Instituto Di Tella foi um âmbito em que alguns artistas de cada uma das duas linhas confluíram, como provavelmente também alguns bares que ofereciam espetáculos noturnos. De modo geral, pelo que é conhecido por registros visuais, a performance dos intérpretes e das bandas do rock argentino não incluiu esse grau de teatralidade nem procurava esse tipo de relação com o público, mas a dramaticidade não estava ausente nem limitada apenas à gestualidade ou às inflexões do canto. Em Grimberg (2008, p 50-51), por exemplo, Moris se refere várias vezes a "sketches" que eram incluídos nas primeiras apresentações. E, já no Capítulo IV, comentamos que é atribuído ao Miguel Abuelo da primeira etapa um modo de interpretação no canto emparentado com o music-hall.

\footnotetext{
${ }^{105}$ Chama-se café-concert a uma modalidade de espetáculo, de muito sucesso na Argentina dos 60 e 70 , na qual se consumia alguma bebida enquanto se assistia. As principais diferenças com o que atualmente acontece em uma casa de shows que serve bebidas são, por uma parte, a combinação de música com dramatização que estamos explicando, e, por outra, o tamanho da sala, menor do que as grandes casas de shows de hoje. Além disso, na especificidade da Argentina da época, o espetáculo de café-concert costumava ter um viés contestatário e humorístico. Não se denominava assim, por exemplo, um show de orquestra tradicional de tango, por mais que pudesse haver degustação de bebidas durante o espetáculo.

${ }^{106}$ Como veremos no Capítulo VIII, a dupla Pedro y Pablo, que se aproximaria do campo do rock argentino depois dos primeiros anos, atuou junto de alguns desses intérpretes.
} 
Enfim, o tipo de interpelação representada em músicas como "Pato trabaja en uma carniceira" é um dos motivos pelos quais pensamos que a regularização discursiva dessa primeira etapa do rock argentino é orientada não apenas pelas tendências dominantes nas transformações culturais e ideológicas da época, mas também por tendências que se observam, ao longo do século XX, na discursividade dos gêneros de tradição popular na Argentina. Por sua vez, as realizações específicas desse tipo de cena no rock argentino nos permitem também indagar o que é que há em comum e o que de profundamente diferente em relação a como ela se articulava em gêneros anteriores, evitando assim diluir a determinação sócio-histórica no essencialismo do que poderia parecer um "modo argentino" ou portenho de enunciar no canto.

\section{Os motivos da condena}

Se observarmos outras composições do período em que um ser representado na segunda pessoa do singular é posto em cena em uma perspectiva total ou parcialmente disfórica, vemos que "Pato trabaja..." é um nítido extremo. É a única em que realmente há uma absoluta condena moral do interpelado. Em "Qué pena me das", de Manal e em "Requiem para um hombre feliz", de Los Gatos, já analisados no Capítulo IV, o ser é mostrado em um profundo engano, e até se vaticina que nunca poderá mudar, mas não se afirma que ele faça mal a outras pessoas. As outras músicas da época em que se produz essa interpelação crítica se realizam em uma enunciação de ensinamento ou conselho, de modo geral prescritivo, mas não de censura: "No, pibe" e "Jugo de tomate frío" (Manal), "Oye niño" (Miguel Abuelo), "Porque bajamos a la ciudad" (Los Gatos), "Alza la voz" (Pajarito Zaguri) e "Verdes prados", de Billy Bond. Em algumas músicas de Almendra, de autoria de Luis Alberto Spinetta, há também um direcionamento didático-prescritivo para um “tu”, mas nesses casos não há sequer descrição avaliativa ("Figuración”, “A estos hombres tristes", "Toma el tren hacia el sur", "Para ir").

Nesse panorama, a composição de Moris que nos ocupa é a única em que o engano, o erro, que também está presente, tem menor peso do que a vileza na descrição do antimodelo. Essa característica a aproxima dos tangos sobre "compadritos" desvalorizados, "milonguitas" e farsantes. Porém, quando observamos em torno de que objetos e de que antecipações imaginárias sobre a vida social e sobre o percurso de vida 
se produz a oposição de valores, tanto "Pato trabaja..." quanto as outras composições que acabamos de referir se distanciam fortemente do universo do tango, em que pese a sua filiação no tipo de interpelação e no tom prescritivo.

A princípio, parece haver uma contraposição que surge do próprio título, "Pato" é um trabalhador e "vos" é um "mantenido". Mas é esse mesmo o princípio traído? Não cremos que, nesta canção, a orientação argumentativa nem as relações interdiscursivas evidenciem um preconstruído sobre o trabalho como condição moral de vida em sociedade, como parece surgir dos tangos afetados pelo processos de disciplinamento que os aparelhos de Estado desenvolveram, na Argentina, concomitantemente com a época de entrada desse gênero na indústria fonográfica e no rádio (MENEZES, 2012). As duas primeiras estrofes, precisamente as dos "dias de ouro" da infância e da adolescência parecem concentrar o que justifica o desapontamento e o "asco". A passagem para essa degradação, resultado do "crescimento" descrito na $3^{a}$ estrofe, é a "indiferença". Em uma composição de Litto Nebbia que mencionamos dois parágrafos atrás, "Porque bajamos a la ciudad", gravada por Los Gatos em $1969^{107}$, também se enuncia uma amizade do passado, que, no presente, virou um desconhecimento mútuo, motivado por uma mudança, no caso, o fato de terem ido "a la ciudad". Embora não haja uma condena moral explícita, e sim engano, trata-se também da perda de um espaço de comunidade. A letra inclui uma parêmia que parece dialogar com a que se repete em "Pato trabaja...", apresentando uma axiologia oposta: "Mi copa es tuya y tu copa es mía".

Tendo a "indiferença" como ponto conclusivo da deterioração moral, a oposição entre "comunismo" e "capitalismo", trazida à música a partir de ter visto "el mundo en los diários", é deslocada fortemente do discurso político da época, e levada ao plano da sociabilidade mais imediata, expressada na recusa de compartilhar. É essa recusa que faz dele "el peor capitalista". Assim, "los otros tienen" parece ser a justificativa do antigo amigo para viver "de arriba", "Cuando tenés te hacés el burro" é a cobrança do decepcionado.

A retórica do locutor, nas estrofes sobre o presente, é principalmente de rejeição. Não se proclama, nela, o programa de ruptura que se esboça em outras músicas do mesmo disco, como "De nada sirve" -com a sua reivindicação de despojo, reconhecimento da

${ }^{107} \mathrm{O}$ encarte da edição original em vinilo registra essa grafia para o título. Uma edição posterior, em CD, dá a forma interrogativa "Por qué bajamos a la ciudad". A primeira nos parece mais acorde com o que é desenvolvido no canto. 
"soledad interna" e saída-, "El oso" ou "Escúchame entre el ruído". O locutor tem em comum com os dessas outras músicas apenas ser detentor de saberes sobre a vida e a "verdade", mas não há, na letra, lugares que o registrem como personagem de um modo de vida, nem que explicitem como poderia ser esse modo. Os dois focos da cena são, no passado idílico, o grupo de pares, representado pelo "nós", e, no presente, o interpelado. Para este não há sequer conselhos: aparece como incurável porque nunca estaria em condições de assumir um programa que passa pela autopercepção sem estímulos ou modelos exteriores. A imprecação "mirate un poco" não deixa de ecoar o "direcionamento para si" representado em tantas outras músicas do rock argentino, mas ela é gritada, na performance, prefigurando muito mais uma humilhação do que um conselho. A perdição do "inútil" interpelado não é tanto sua ambição, já que apenas procura sobreviver "de arriba" e com pequenos enganos, mas o fato de ele ser "de mentira". Sua relação com a arte, além de não incluir a menção de alguma prática específica, também é apresentada como falsa, mediante construções que, no espanhol, se relacionam a sentidos de fingimento, tais como "estás en artista", "te hacés el gênio", "hacerte el raro".

\section{Apenas um aceno}

Voltando ao locutor, cremos que sua escassa representação como personagem na cenografia do presente e sua permanência exclusiva nas inflexões da voz indignada é complementar com outra lacuna, a mais interessante da música, e que tem a ver com Pato. Tanto o Pato personagem de uma única ação, trabalhar num açougue, quanto o Pato etiqueta de um enunciado que se repete, como título e na música, sem que sua articulação com a cena seja nítida. Qual é, então, o lugar de "Pato" na contraposição que se desenvolve entre, por um lado, o egoísmo indiferente, fingidor e frívolo, e, por outro, o saber sobre a vida que dá base à indignação da voz? O que mais se destaca é a introdução assindética, quase como uma incidental entre parênteses, da fórmula "Pato trabaja en uma carniceira". O canto também não lhe acrescenta qualquer distinção no tom, no timbre ou no volume, que pudesse direcionar a relação semântica estabelecida, ou ainda sugerir a atribuição a outro enunciador. O enunciado aparece na segunda estrofe, quando se diz que "nos fuimos del barrio" mas ainda é o tempo da adolescência. Pato trabalhava enquanto eles andavam pelos roseirais procurando namoradas? Um passado está sendo narrado, 
mas "trabaja" está no presente. Da falta de fechamento mediante qualquer conectivo deriva uma relação de contraste, sendo a mera simultaneidade a primeira que surge a falta de outra. E a atribuição de alguma valoração positiva a Pato e seu trabalho, em contraste com a vileza do outro, vem a partir da relação com praticamente qualquer uma das mais divergentes visões de mundo consolidadas na dimensão ideológica da época, ou inclusive de hoje. O problema é que, precisamente, essa positividade pode relacionar-se a posicionamentos muito diferentes, como o mostram estas duas expansões :

(1) Pato, porque trabalha em um açougue, é melhor que você

(2) Pato, embora trabalhe em um açougue, é melhor que você.

Cremos que o particular modo de presença da formulação "Pato trabaja en uma carnicería", primeiro como título, depois como parentética e, por último, como final repetido no canto, aponta para vários lugares de contradição. Na enunciação musical, o título antecipa ao ouvinte um tópico que permanecerá sem desenvolvimento. Na interlocução representada entre o "eu" e o "tu", "Pato" é identificável para ambos, dado que é introduzido com um nome próprio, mais do que isso, um apelido coloquial. Ele não está para servir de modelo oposto à ética e ao comportamento do ser interpelado: na música se trata muito mais, e mais diversamente, deste do que de Pato. O espaço do locutor-personagem e o do seu interlocutor desprezado é o mesmo, é nele que se disputa a legitimidade, inclusive no que diz respeito ao ser artista ou "estar en artista".

Diferentemente, o âmbito do trabalho braçal, o de Pato, é claramente apresentado como outro. Esse âmbito é invocado contra a "indiferença" condenada, mas é outro. Pato poderia ser parte "del mundo y de las personas" das quais o interpelado ri, e, mais importante, das quais o locutor mostra saber (devolvendo como registro do olhar) que o outro ri. Para ambos os níveis de interlocução, o nível representado na cenografia e o nível operado pela voz, no canto, em relação ao ouvinte, Pato é trazido como um convidado. Se há uma "homenagem" ao mundo do trabalho, ou à condição de proletário, prefigurada pela emergência de um léxico das esquerdas políticas ("burguês", "comunismo", "capitalista"), essa condição é trazida para um conflito de tipo ético da sociabilidade entre indivíduos, como uma virtual perspectiva extraposta. Dificilmente pudesse ser de outro modo quando, como veremos extensamente no Capítulo VIII, a encenação da luta política fica relativamente fora nessa primeira época do rock argentino, funcionando como um dos exteriores que marcam sua fronteira, e esta composição parece 
ser um dos lugares onde ela se marca. Pato é um olhar em potência a partir do qual a voz acena olhar seu corpo de interlocutores, mas é só potência. $\mathrm{O}$ olhar em ato é o do sol.

Incorporando a epígrafe a nossa leitura, a condição outra do lugar de Pato é mais nítida ainda:

\section{PATO TRABAJA EN UNA CARNICERÍA}

Falsos hippies, burgueses frustrados y toda mi rabia contra algunos de ellos, y entre medio Pato, Pato de Palermo, que allá estará bajando medias reses, sin saber nada de todo este circo. Todo el amor que sentí alguna vez por él y por mis amigos del Zoológico, poetas del reaje único y auténtico de los quince años.

O breve texto começa pelo rejeitado, "falsos hippies", "burgueses". Pato, que irrompe "entre medio", é logo reformulado pelo aposto "Pato de Palermo" e afastado pelo demonstrativo adverbial mais longínquo e por uma forma verbal hipotética: "allá estará bajando medias reses, sin saber nada de todo este circo". A menção do bairro (Palermo) para construir um epíteto, por remeter à discursividade do tango e por não ser uma fórmula que se encontre no rock argentino da época, nem sequer nas letras do próprio Moris, reforça o efeito de distância ${ }^{108}$. Pato está longe e, sobretudo, ele está "sin saber nada de todo este circo". Não é posto, na perspectiva desse terceiro, o saber que há, sim, no "eu" e no "tu".

A epígrafe se encerra com uma evocação dos quinze anos com o termo "reaje", trazendo novamente o discurso tangueiro, em relação ao qual se opera um interessante deslocamento. "Reo", funcionando como adjetivo, no repertório léxico do tango, é um dos termos com que se exalta a implantação no subúrbio (FLORES, 1987) autêntica, sem refinamentos. Pode ser referido à fala ou a qualidades de quem é boêmio. A confluência, no mesmo termo, de sentidos relacionados ao desleixo na aparência, bem como seu valor no discurso jurídico (equivalendo a "réu" em português), fazem dele um dos itens lexicais que, na tradição discursiva tangueira, apontam para uma relação ambivalente e crítica

\footnotetext{
108 Não encontramos, com efeito, no corpus do primeiro período, nem também no que conhecemos do desenvolvimento do campo pelo menos até sua forte diversificação a partir dos 80 , qualquer registro desse tipo de aposto que se encontra, sim, no tango, por exemplo "Soledad, la de Barracas", "El Pibe Palermo", "Flor de Montserrat".
} 
com o disciplinamento social. Na epígrafe de Moris, "reaje" vem também para um efeito de sentido de autenticidade, porém, não determinado principalmente pelo bairro, mas pelo grupo de amigos da adolescência, contraponto dos "falsos hippies" e "burgueses frustrados".

Tanto a música quanto esta epígrafe nos põem diante de duas diferenças cruciais entre a regularização discursiva inicial do que seria o rock argentino e o tango canção, diferenças que abordamos porque se relacionam aos nossos objetivos, embora não seja nossa intenção uma comparação abrangente entre esses dois campos. Por uma parte, o bairro, embora seja ocasionalmente mencionado, não tem a centralidade com que conta nas topografias do tango. Não há, por exemplo, prosopopeia do bairro nessa etapa do rock argentino. Se, como afirma Campra (1996, p 58), para o tango o subúrbio é o único espaço verdadeiro e por isso castiga os que o abandonam, no rock argentino dos primeiros tempos, a autenticidade não radica em nenhum lugar em especial de "este mundo que está podrido". O "autêntico" está relacionado à "saída" do engano, que, embora possa invocar, como nesta música, o cenário de uma comunidade de iguais, ou, como em outras, a natureza, é recorrentemente relacionado à (re)descoberta de si. Por outra parte, vem à tona aqui um dos traços que, como vimos no Capítulo III a partir de Colomba (2010), afastam do melodrama a discursividade do rock argentino: não há trunfo da virtude, vitória que aparece de diversas maneiras nos tangos em que se interpelam personagens escarnecidos. Nem o tempo, nem a doença, nem o bairro ou a vergonha familiar são, como eram no tango, carmas compensatórios contra os "canalhas" no primeiro rock argentino, e nem sequer no conjunto do período prévio à sua massificação na década de $1980^{109}$.

Relacionamos essa diferença com o tango ao fato de que o rock argentino da época não está sob os efeitos de um processo de disciplinamento social relacionado à construção de um imaginário de nação, como acontecia com o tango durante sua entrada na mídia nas décadas de 1920 e 1930 (LINCUIZ, 2010), processo com o qual os tangos de “interpelados" dialogam contraditoriamente, como explicam Menezes (2012) e, de outra maneira, Garramuño (2009, p 121-138). O rock argentino é, na época, uma expressão claramente contracultural, para a qual, como aponta Pujol (2007b, p 16), "la búsqueda de una identidad local nunca estuvo por encima del deseo de consolidar una cultura joven disidente". E, como propomos neste trabalho, sua discursividade vai se constituindo na

\footnotetext{
${ }^{109}$ E mesmo depois, conhecemos poucos exemplos. Um deles é "Yo no me sentaria en tu mesa" de Los
} Fabulosos Cadillacs, gravado em 1987. 
interseção de uma impronta cética com discursos relacionados às práticas culturais transformadoras que já referimos no Capítulo II, incluindo o conjunto do campo do rock no mundo, que realizam um aberto questionamento da moral e das crenças que dão fundamento à ordem estabelecida.

\section{Heterogeneidade e estabilização}

Para completar nossa análise do funcionamento das perspectivas e olhares postos em jogo na música, iremos agora ao que motivou a inclusão das considerações sobre esta composição precisamente nesta parte do trabalho: a prosopopeia "y el sol miraba sin preguntar”. Diferentemente de Pato, que, como vimos, não é depositário de um saber e permaneceu na inocência de "não entender" o egoísmo, o sol sabe, porque tem olhar. Inclusive, aparece olhando (e sabendo) na mesma parte da música $-1^{\mathrm{a}}$ estrofe- em que o "nós" aparece na não compreensão do egoísmo. Esse olhar devolve a perspectiva do "nós", e portanto as do "eu" e do "tu”, de uma maneira que não poderia ser a de nenhum deles em tanto personagens da cenografia. Trata-se de uma das expressões mais nítidas da leitura que, no capítulo anterior, propusemos para a prosopopeia perceptual, como duplicação centralizadora e isolante do representado, que reforça a função locutora mais externa e o próprio processo de encenação, aproximando-o do enunciador universal.

O espaço dos "dias de ouro" é posto sob esse olhar, especificado pela negação "sin preguntar”. Essa negação se abre a dois pré-construídos. Por um lado, que aqueles que não têm essa visão-saber poderiam ter necessidade de perguntar. Por outro, que esse panorama da infância que ainda não conhece o egoísmo não suscita interrogação ou questionamento para o lugar de saber universal sob o qual é posta a interlocução, mas que as situações posteriores poderiam motivar esse questionamento. Desse modo, é antecipado o gesto interpelador que domina quase todas as estrofes seguintes. O locutor já está, nelas, desdobrado em personagem, precisamente porque fala diretamente ao outro, e não coincide, portanto, com o enunciador universal. Mas compartilha de seu saber, que a voz leva plenamente à relação intérprete-ouvinte.

A figuração do sol contribui para estabilizar esse lugar de saber em um canto que é mais atravessado pela heterogeneidade enunciativa do que os de outras composições do 
período. O discurso indireto livre, raro nas músicas do rock argentino em formação ${ }^{110}$, aparece trazendo a voz do interpelado precisamente quando começa a sequência de acusações, no final da terceira estrofe:

\section{Tenés excusas, los otros tienen.}

Que te mantengan, para eso están.

A segunda aparição da fórmula do egoísmo, "lo tuyo, mío, y lo mío es mío", irrompe nessa mesma $3^{\mathrm{a}}$ estrofe já não encaixada, como na $1^{\mathrm{a}}$, em caráter de citação de "aquel chiste que decía", mas em continuidade, como algo que a voz do locutor traz de um espaço verossímil de circulação de dizeres. Esse espaço também é lugar de um conhecimento, no caso, desapontador: o mundo que "hemos conocido" pelos diários. O "comunismo", palavra alheia por provir desse saber inautêntico, é deslegitimado pelos mesmos que o formulam, em outra afirmação -“el comunismo resultó complicado"- que pode ser atribuível a uma voz não coincidente com a do locutor personagem, ou a uma modulação irônica desse locutor.

Sobre o amigo Pato, propúnhamos alguns parágrafos atrás que ele aparece como um olhar em potência. Outros campos da música popular, como outras práticas na produção de bens culturais na época, punham em cena vozes atribuíveis a um locutortrabalhador explorado, ou levavam essa exploração para o centro do conflito. Elas fazem parte, portanto, do escopo desta canção, cujas possibilidades de sentido têm como condição de produção o recorte que a separa delas. É um dos casos em que a discursividade em consolidação no rock argentino mais se aproximou dessa fronteira. A presença persistente e assindética de Pato desde o título, bem como as formas de heterogeneidade que acabamos de comentar, parecem traços dessa aproximação desestabilizadora. E o sol olhando reforça o lugar de saber que dá estabilidade.

${ }^{110}$ Outra das poucas em que aparece é "Jugo de tomate frío", de Javier Martínez, com Manal: "Eligiendo inteligentemente, todo el mundo podrá ser feliz". 


\section{Capítulo VIII \\ A (não) encenação da luta política}

(Não indiferença)

Ao tratar sobre a localização do nascente rock argentino nos debates da época sobre a necessidade de transformação social, o compromisso e a práxis política, vimos, no Capítulo IV, que, de modo geral, não teve expressão nesse movimento o deslocamento da atividade artística para um laço mais ou menos orgânico com a participação política. Não houve praticamente nenhum artista do campo do rock argentino que se envolvesse em militância em partidos nem em movimentos sociais. Como observamos naquele capítulo a partir de Terán (1991 e 2008), Rozitchner ([1966] 1968), Jacoby (2011), Longoni (2004), Altamirano (1992) e outros estudiosos, essa opção, mais ou menos declarativa, mais ou menos ativa, caracterizou uma boa parte dos produtores de bens simbólicos entre o final dos 60 e começos dos 70.

Isso tem trazido como consequência que se considere o rock argentino daquela época como politicamente omisso, representação que, de alguma maneira, conjuga com a acusação da esquerda sessentista contra as vanguardas artísticas quando estas não assumiam uma prática enunciada como revolucionária, que referimos no Capítulo II. É diferente a visão dos que efetivamente estudaram esse campo da música popular e que, mesmo para suas primeiras épocas aparentemente "despolitizadas", percebem uma complexidade de fatores que integram “o político". Díaz (2005, p 143-189) desenvolve uma extensa e abrangente reflexão sobre o rock argentino em relação à formulação de utopias, ao protesto especificamente referido ao poder do Estado, à lei, e, depois, à sobrevivência já em tempos da ditadura (período que, como já estabelecemos, este trabalho nosso não inclui). Provéndola (2015), em um estudo cujo foco é o que o poder estatal fez com o rock ao longo de meio século, considera que, na Argentina, o rock começou sua construção à margem da política e que "a la mayoría de los primeros rockeros los dominaba una profunda abstracción sobre los avatares de la política doméstica" (p 70). Não por isso deixa de situar a emergência do denominado "rock nacional" no contexto de uma série de gestos de resistência. 
Pela nossa parte, cremos necessário, para abordar o problema a partir dos nossos objetivos neste trabalho, diferenciar dimensões do político. Por opção teórica, pensamos que o político está em toda prática social, e que é intrínseco à enunciação. Há politicidade em praticamente tudo que temos exposto até agora em torno do primeiro rock argentino: no fato de situar-se na divisão do linguístico como cantar em castelhano, na sua delimitação contraditória a respeito de determinados modos de patetismo, na sua representação da mudança e da crise no ser, na sua delimitação conflitante e dissidente a respeito de determinados comportamentos e valores, nas reconfigurações que faz de materialidades de outros gêneros da canção popular e da cultura de massa. Há política na formação das vozes e dos corpos -de escuta e de fruição- que a enunciação ocasiona nas canções. Enfïm, nosso estudo sobre a regularização discursiva nesse campo é um percurso sobre o político porque há ideologia e posições de sujeito. E houve, em outros aspectos das práticas desse campo em formação que não abordamos neste trabalho, incluindo seu público, uma política dos corpos que, como, bem lembra Manzano (2014), enfrentou não pouca repressão em relação a cabelos compridos, roupas coloridas e consumos reais ou supostos.

E ainda se consideramos uma dimensão mais restringida do político na canção ou em qualquer forma artística, por exemplo, que ela tenha como objeto aquilo que em determinada formação social aparece como diretamente ligado ao poder públicoou à desigualdade, também não há como dizer que o rock argentino, sequer nas suas primeiras épocas, não incluiu essa dimensão temática nas suas letras e nas vozes que fez ouvir. Pouco, se comparado com campos próximos da canção urbana de tradição popular, como o Nuevo Cancionero do folclore ou a Nueva Canción ligada ao café-concert e ao teatro realista, mas não esteve ausente. Os abusos policiais são um tópico reiterado, como a opressão no espaço escolar, e, em menor medida, a desigualdade social. E, como admitem todos os estudiosos referidos, são temáticas que começam a ocupar um espaço relativamente maior nas letras à medida que a situação argentina se radicaliza na passagem entre as décadas de 60 e 70. 


\section{Delimitando uma ausência}

O que é que parece ter faltado, então, no primeiro rock argentino em relação ao político? Daremos início a nossa tentativa de responder essa interrogação referindo uma afirmação de Colomba (2010), particularmente extrema, que nos permitirá situar acordos e desacordos. Ao localizar, nas canções dos pioneiros, um "carácter autoafirmativo" que motivaria uma frequente referência, nas letras, à própria atividade de músico, propõe que esse traço é solidário com:

esa suerte de autismo histórico-social que exhiben abiertamente las letras del primer período: en ellas casi no hay referencias, con poquísimas excepciones, a las huelgas y tomas de fábrica generalizadas, a las rebeliones populares, a las numerosas organizaciones armadas que ya están operando por ese entonces, a la militancia política de amplios sectores de la juventud, a la mujer como nuevo actor social que trasforma radicalmente la cultura argentina. (COLOMBA, 2010, p 42-43)

O primeiro a levar em conta é que as "letras del primer período" começam a ser compostas em torno de 1965, enquanto que a enumeração de fatos e de processos políticos e sociais que detalha Colomba é localizável, nessa profusão e dominando a percepção de setores amplos da sociedade, somente a partir do ponto de inflexão que é 1969. A série de insurreições populares urbanas desse ano, em Rosário primeiro e principalmente o “Cordobazo" de 29 e 30 de maio, mudam radicalmente a situação argentina, embora já houvesse um acúmulo prévio de resistência à ditadura de Ongania. Como explica Gordillo (2003, p 332):

Entre 1969 y 1970 se produjo un momento explosivo. En ese corto lapso emergió lo acumulado en los años previos, estallando la rebelión popular y conformándose movimientos sociales de oposición al régimen que ensayaron nuevos repertorios de confrontación.

Porém, concordamos com Colomba em que, inclusive depois de 69 e em plena radicalização, esse panorama não parece ser registrado entre os objetos de discurso e cenografias do rock argentino. As formas mais evidentes dos enfretamentos de classe na época, quase omnipresentes em outros campos da cultura de massa, inclusive na telenovela tradicional e na história em quadrinhos dos grandes jornais (Carassai, 2014; Levin, 2010), não aparecem como assunto nas letras do rock argentino. No entanto, como tentaremos expor nos capítulos seguintes, em aspectos que não se oferecem à evidência 
da declaração, esse real crescentemente violento de enfrentamento desigual afetou, sim, a regularização discursiva na "música progressiva" do país.

Cremos que aquilo que quase não houve nas composições do rock argentino praticamente até finais dos anos 70 foram cenografias da luta social e política, e, portanto, também não houve vozes e/ou personagens, singulares ou coletivos, mais ou menos ficcionalizados, relacionados a uma representação imaginária dessa luta. E não houve mesmo quando a censura não teria conseguido agir especificamente nesse plano, como não conseguia sobre outras expressões culturais que não ocupavam espaços centrais da mídia. Parafraseando uma canção de León Gieco composta em 1972, o rock argentino registrava os "hombres de hierro", a repressão, mas não a "gente que avanza"111.

Poderíamos dizer que essa não encenação da luta política constitui uma "borda" no rock argentino dessa época, mas não do tipo de exterioridade que analisamos no Capítulo III para determinadas formas de narrativização da morte e do amor. Não se trata aqui de uma lacuna "indiferente", que só possa ser percebida em uma pesquisa que interrogue a série por fora das expectativas ou da metalinguagem sobre o campo na cultura de massa. As relações do rock argentino com o político, não necessariamente conceitualizadas como tentamos aqui, são, como foram na época, um assunto tratado e discutido, de maneira nenhuma indiferente.

\section{Alguns limites}

Também para essa exclusão em relação à luta política houve casos limítrofes, cuja observação deixa ver o campo como relacionado a um "agrupamento do discurso" diferenciado nas práticas sociais, conforme tratamos essa categoria no Capítulo I. Essas "bordas" se produzem em um período em que o campo já está consolidado e conta com um público relativamente estendido, revistas específicas e shows crescentemente periódicos.

A mais notável é a da banda Alma y Vida. A que talvez seja sua composição mais lembrada, "Hoy te queremos cantar", deu lugar a uma situação especialmente interessante para o que estamos explicando. Trata-se da uma das pouquíssimas músicas ${ }^{112}$, nas

\footnotetext{
${ }^{111}$ No refrão de "Hombres de hierro", esse compositor do rock argentino canta "gente que avanza se puede matar, pero los pensamientos quedarán."

${ }^{112}$ A única se não se considerar Roque Narvaja como parte do rock argentino. Como explicaremos seguidamente, parece-nos muito distante.
} 
primeiras etapas do rock argentino, em que aparece algo que, no Capítulo III, indagamos como parte de uma carência, o assassinato de alguém específico, no caso, um assassinato de um lutador político. Quando a música foi gravada, em 1972, foi entendida por muitas pessoas como homenagem ao Che Guevara. Na letra não apenas não havia nomes, como também não se percebia uma tentativa de referir a alguém em especial, e havia inclusive imagens que se afastavam das circunstâncias da morte do Che: "Como a um río, te dejaron sangrando en la ciudad / todos te vimos caer / caer sin poder llorar". A banda esclareceu que não tinham pensado em Guevara, mas que gostavam de que as pessoas tivessem feito essa relação ${ }^{113}$. Até hoje a canção é apresentada em blogs e canais de Youtube como dedicada ao Che.

Alma y Vida chega ao "progressivo" argentino depois de ter sido acompanhamento do baladista romântico Leonardo Favio ${ }^{114}$, e por isso arrancou com um apoio da indústria cultural que não tinha sido da mesma maneira para nenhum dos precedentes, o que de início colocou a banda com "um pé fora" do "progressivo". A orquestração das gravações lembrava a sonoridade dos "convencionais" ou até dos chamados "melódicos" da produção seriada transhispânica, como Julio Iglesias, Sergio Denis ou o próprio Favio, nas antípodas das identificações roqueiras. Em abril de 1974, quando já tinham 3 discos publicados e eram vistos como "outra coisa", a revista GENTE, meio de massa de informação geral que nunca tinha feito uma entrevista integral com uma banda de rock argentino, publicou uma extensa reportagem sobre o grupo, incluindo um quadro de dados pessoais dos músicos com o seguinte cabeçalho:

Leyendo este recuadro, usted tal vez se sorprenda. En él descubrirá que todos los integrantes de "Alma y Vida" son casados, tienen uno o varios hijos. Es una manera de desvirtuar muchas cosas que se dicen respecto de los jóvenes que hacen música moderna ${ }^{115}$.

\footnotetext{
${ }^{113}$ Em uma entrevista dada anos depois, publicada pelo jornal La Capital de 13/10/2002, o ex baixista da banda, Bernardo Baraj, explica: "en realidad el tema estaba pensado para un personaje paradigmático de la época en el sentido del paradigma de lo revolucionario, de la lucha, y el Che calzaba muy bien en el espíritu de lo que se decía desde la letra, pero en realidad no había estado pensado para él. Por supuesto que cuando la gente se adueñó del tema y dijo que estaba dedicado al Che, a nosotros nos pareció muy grata esa decisión del público". Fonte: http://www.rock.com.ar/notas/0/409.shtml

${ }^{114}$ Figura singularíssima da cultura de massa argentina na segunda metade do século XX, Leonardo Favio começou no cinema como ator e logo como diretor, em filmes considerados de vanguarda, com inspiração da nouvelle vague. No final dos anos 60, surpreendeu iniciando uma carreira na música romântica e melódica, que lhe trouxe sucesso de vendas imediato no pais e no mercado discográfico em espanhol. Em 1973 voltou a filmar como diretor, alternando, a partir de então, as duas modalidades.

115 “Como su nombre lo indica: tocan con alma y vida”. GENTE n 454, 22/4/74, p 40-43.
} 
Alma y Vida é pouco lembrado como banda de rock, sendo até hoje uma figura de difícil definição, localizada, por vezes, em uma memória histórica do progressivo argentino, devido mais ao trabalho posterior de alguns de seus integrantes do que à sua própria produção como banda. O tecladista e trompetista Gustavo Moretto, ao separar-se do conjunto, foi para um grupo plenamente identificado com o mais elaborado do rock argentino na sua segunda época, "Alas", principalmente instrumental e com propostas de fusão com tango e jazz. Mas a voz principal e líder da banda, Carlos Mellino, foi para a música romântico-melódica, afastando-se nitidamente do campo do rock.

O outro caso para considerar nestas "bordas" é a dupla Pedro y Pablo, a uma de cujas músicas, "Catalina Bahía”, nos referimos brevemente no Capítulo III. Integrada por Miguel Cantilo e Jorge Durietz, Colomba (2010) dá como exemplo de exceção em relação ao "autismo histórico-social" que, como já citamos, vê nas letras do primeiro rock argentino. No que diz respeito ao traço que nós apontamos como característico, isto é, a não encenação da luta social e política e seus sujeitos coletivos, não seriam exceção. A percepção deles como músicos mais "politizados" tem a ver com outros fatores, que determinaram uma relação particularmente complexa -"não ortodoxa", para Provendola (2015, p 81)- com o rock argentino. A dupla de Cantilo e Durietz tem uma implantação histórica nesse campo muito mais reconhecida do que a de Alma y Vida. Porém, eles chegam ao rock depois de compor parte de seu repertório e de se darem a conhecer em outros espaços e em relação a outras tradições, gêneros e agrupamentos.

Começaram como dupla de cancionistas, só com violão acústico, e tocando em espaços de café-concert. Relacionaram-se assim à corrente da "Nueva Canción Argentina", que referimos no Capítulo VII, principalmente a Jorge Schussheim e a Nacha Guevara. Isso significava uma ponte com as vanguardas artísticas do Di Tella, mas também, sobretudo no período de radicalização política que se vivia, com as preferências "realistas" da Nueva Izquierda e seus aparelhos no campo cultural. E, por outra parte, como explicamos também ao tratar sobre a Nueva Canción, o próprio âmbito do caféconcert recolhe linhagens do music hall, o que, na cultura portenha, significava vínculos com o espetáculo popular em gêneros nos quais a paródia ou o humor eram, de modo geral, muito mais presentes do que no primeiro rock. Por exemplo, sua música “Asociación Modelos Argentinas" podia ter sido perfeitamente de cantores de caféconcert.

No entanto, o repertório de Pedro y Pablo não deixa de mostrar, em boa parte das suas canções, traços caros à discursividade do rock no mundo e inclusive da 
especificidade da regularização discursiva do rock argentino. Sua música "Los caminos que no sigue nadie", por exemplo, reúne muitos dos tópicos que mostramos no percurso do Capítulo IV acerca do deslocamento do ser na "mudança crítica", e poderia ter sido incluída nas análises daquela seção se não fosse um pouco posterior. Porém, algo que os caracteriza e lhes dá certa singularidade é uma expectativa diferente de referencialidade nas cenografias. No Capítulo VII propusemos, a partir da nossa análise do disco de Moris e de considerações de Sergio Pujol, que o primeiro rock argentino não se ancora numa identidade "local", nem nacional nem portenha, embora ocasionalmente haja menção de lugares específicos. Nas músicas de Pedro y Pablo, em compensação, o país e a cidade como representações específicas são objetos incontornáveis.

Essas especificidades explicam, do nosso ponto de vista, a leitura sempre “diferenciada" que se faz dessa dupla clássica de Cantilo e Durietz e não, por exemplo, de formações posteriores protagonizadas por Cantilo dentro do rock. Nesse contexto, há uma superestimação da "temática política" das suas letras. São poucas, embora muito famosas, as músicas do repertório de Pedro y Pablo com essa característica. Elas não se distinguem das outras poucas composições "politizadas" que encontramos no rock argentino por encenarem os processos de luta e seus sujeitos pragmáticos. Pelo contrário, como as das bandas mais "nucleares", focalizam fundamentalmente a repressão. Músicas de Pedro y Pablo como "La marcha de la bronca" ou "Yo vivo en una ciudad", ou incluso a fortíssima "Apremios ilegales", que descreve a tortura, se diferenciam de "Blues de la amenaza nocturna", de Javier Martínez, ou de "Hombres de hierro", de León Gieco, apenas pelo modo de tratamento do verossímil. E em nenhuma delas se percebe uma orientação argumentativa análoga à da esquerda revolucionária da época, mas o pacifismo que caracterizou, de modo geral, a aproximação dos roqueiros do discurso político. $\mathrm{O}$ final de "La marcha de la bronca" é um claro exemplo. Uma música que poderia ter feito parte de um repertório de protesto para eventos da militância concluía com "Bronca sin fusiles y sin bombas / Bronca con los dos dedos en V." O signo de "V" com os dedos, que para boa parte da esquerda representava a vitória, ou "Perón Vuelve", ou o "venceremos" da bandeira montonera ${ }^{116}$, entrava claramente, na música, nas relações de sentido do discurso dos movimentos pacifistas e dos hippies. De fato, quando fragmentos

\footnotetext{
${ }^{116}$ Montoneros foi a principal organização armada da esquerda peronista, criada nos últimos anos da
} década de 60. 
editados da música foram parte da trilha sonora do filme Los traidores, de Raimundo Gleyzer, esse segmento final não aparecia ${ }^{117}$.

Por último, vale a pena fazer uma referência ao cantor e compositor Roque Narvaja. Começou, nos anos 60, no grupo convencional e "nuevaolero" La Joven Guardia. A partir dos 80 continuaria sua carreira na balada romântica, mas, previamente, teve, entre 72 e 74, uma breve passagem pela canção de protesto. Narvaja compôs uma canção sobre o militante Luis Pujals, sequestrado e assassinado em 1971, um dos primeiros desaparecidos da Argentina ("Balada para Luis") e outra sobre os guerrilheiros Ernesto Guevara e Camilo Cienfuegos ("Ernesto y Camilo"), ambas gravadas no seu primeiro LP solista. Nesse disco adquire, por momentos, uma sonoridade próxima de algumas linhas do rock local, mas não chegou a ser identificado como um músico de rock, e nos discos seguintes, ainda na sua etapa contestatária, se relaciona mais a ritmos foloclóricos ou ao melódico-romântico.

Enfim, um interrogante que poderia surgir é se o fato de essas bandas e músicos que acabamos de referir (Alma y Vida, Pedro y Pablo, Roque Narvaja) mostrarem, de diferentes maneiras, uma relação com o político distinta da que predominou no rock argentino contribuiu para que permanecessem nas suas bordas ou fora dele. Optamos por uma leitura inversa: o fato de terem frequentado outros espaços e de terem participado de outras modalidades da música popular pode relacionar-se à percepção dessa diferença pelos aficionados. No caso de Pedro y Pablo, os mais localizáveis "dentro" do campo, cremos que seu modo de tratamento do verossímil faz com que a representação da repressão estatal, presente também nos outros roqueiros como objeto de discurso, ganhe uma forma mais próxima da música de protesto da época.

\section{Uma nova alteridade em relação à militância}

Provendola (2015, p 54-55), ao tratar sobre a relação aparentemente distante entre o primeiro rock e a vida política, dá três explicações. Uma seria o fato de a política ser vista pelos roqueiros como parte do mundo adulto, e, portanto, como inautêntica. A segunda, que "el concepto de militância pública y colectiva no armonizaba con el ideal

\footnotetext{
${ }^{117}$ Filmado em 1973 pelo grupo "Cine de la Base”, ligado ao Partido Revolucionário de los Trabajadores e ao seu braço armado, o Ejército Revolucionario del Pueblo, o longa-metragem combinava documentário com ficcionalização para contar a história de um dirigente sindical. Os fragmentos da música de Pedro y Pablo acompanhavam imagens do Cordobazo.
} 
rockero de cambio interno e introspección privada", e a terceira, um auge nacionalista na política argentina da época que desfavoreceria o rock por ser visto como de origem anglosaxã. Tendemos a não concordar com essa análise, em primeiro lugar porque ela se refere já aos inícios dos 70 quando, como veremos, a generalização e popularização da atividade política vai levando a uma interseção de jovens roqueiros e militantes. Por outra parte, as fontes nas quais o autor se apoia sobre o "ideal” de introspeção são respostas dos próprios músicos, na época, quando eram questionados, na mídia e/ou pelas próprias organizações militantes, sobre por que não tinham uma "definição" política. Portanto, eram respostas formuladas sob uma predeterminação sobre o que era "político" e sobre sua condição de "não definidos" politicamente, como um de vários rótulos cristalizados que circulavam na discursividade. Trazemos à tona aqui a noção de "formações imaginárias", formulada em um dos textos que deram início à corrente francesa de análise do discurso (PÊCHEUX, [1969] 1997, p 79-87). As formações imaginárias, nos processos discursivos, são o conjunto de imagens que os interlocutores fazem uns dos outros, bem como dos objetos dos quais falam, em função dos lugares que esses interlocutores ocupam na formação social, e, portanto, também no confronto político e cultural. Nesse jogo de imagens há antecipações sobre as representações do interlocutor, que pensamos que explicam as respostas "polarizadas" dos músicos do tipo "minha revolução é primeiramente interior", que abundam no material relevado por Provéndola.

O que nos parece questionável é que a argumentação de Provéndola parece capturada, quarenta anos depois, pelas mesmas formações imaginárias, sem tentar observar, como pretendemos nesta tese, a "introspeção" e as de larações de "mudança interior" na sua contradição necessariamente política. E, por último, não concordamos com a avaliação porque, se isso era perguntado aos músicos a partir dos próprios espaços da esquerda militante, é porque as condições tinham mudado muito em relação aos 60 . Nos primeiros anos do "progressivo", isto é, 65 a 69, o movimento era simplesmente ignorado pela esquerda, ou desprezado, como o próprio autor também mostra no seu livro. Mas se considerarmos 1971 e os anos subsequentes, a esquerda militante já não é a mesma.

A partir da explosão social que se inicia com o Cordobazo, em poucos anos novos setores juvenis se incorporam às lutas, como os estudantes secundaristas, que ocupam ou fazem greves em numerosos colégios (CARASSAI, 2014, p 84-107). Esses novos jovens já chegavam às organizações tendo passado a puberdade e parte da adolescência escutando rock estrangeiro e, uma parte deles, rock nacional, que já era um campo 
relativamente consolidado e com algumas bandas conhecidas. $\mathrm{O}$ excelente trabalho de pesquisa documental que expõe Manzano (2014), incluindo publicações das organizações de esquerda revolucionária, mostra que esses partidos começaram a ter uma política em relação ao rock, que já não era a do desdém. Os roqueiros e seu público são vistos pela esquerda como positivamente rebeldes, mas "sem ideologia", com necessidade de "definição". A mesma autora, em uma pertinente comparação com outros países da América Latina, permite ver que, na Argentina dos primeiros 70, o rock não carregou o estigma de estrangeirismo ou de arma cultural do imperialismo. Prova disso foram as diversas tentativas, pelo geral mal sucedidas, por parte das juventudes dos partidos, de aproximar as bandas dos seus eventos.

\subsection{As formas da revolta e do terrorismo de Estado}

Todos esses setores começavam a ser objeto da mesma violência de Estado e paraestatal, cada vez mais intensa. Do outro lado, também crescia a ação das organizações armadas de esquerda e, por outra parte, um novo sindicalismo combativo dava lugar a formas de luta mais radicais (GORDILLO, 2003). Em agosto de 1972, ainda sob o governo ditatorial de Lanusse, presos políticos, a maioria deles de organizações armadas, realizam uma fuga da prisão de Rawson, na Patagônia. Alguns conseguem fugir ao Chile em um avião que ocupam, outros se rendem e se entregam diante de jornalistas e juízes. Os rendidos foram levados à base aeronaval de Trelew, onde foram fuzilados no dia 22 de agosto. Os militares da base e o governo tentaram criar a versão de uma segunda tentativa de fuga e de um enfretamento, mas os depoimentos dos sobreviventes e o fato de que todos tinham sido fotografados pela imprensa entregando as armas deixaram em evidência o fuzilamento (GODOY SEPÚLVEDA, 2012). O episódio, conhecido como "Massacre de Trelew", deixou clara a disposição das forças armadas a empregarem os métodos de guerra civil e repressão ilegal que desenvolveriam amplamente nos anos seguintes, e que anteciparam a generalização do terrorismo de Estado praticado pela ditadura de 1976 a 1983, a mais sangrenta da história da América do Sul no século XX. Faltavam anos para o início da ditadura, mas o terror estatal coexistia com as expectativas revolucionárias desde pelo menos 1971, e se manifestava em prisões arbitrárias e grupos paramilitares. Trelew foi apenas seu anúncio mais evidente.

Seria descabido pretender resumir, no curto espaço que isso pode ocupar em um trabalho que tem como objeto o discurso em materialidades muito específicas, o peculiar 
ambiente de tensão em uma sociedade que via crescer conjuntamente, como duas realidades que pareciam não conjugar-se, ações radicalizadas de luta e uma repressão feroz. Apenas apontaremos brevemente alguns traços que nos parecem necessários para tentar situar uma atmosfera de urgência e de pavor que fez parte das condições de desenvolvimento do que abordaremos no que resta deste capítulo e, sobretudo, nos dois seguintes.

O curto intervalo não repressivo que significou a assunção ao poder de Héctor Cámpora, vencedor nas eleições de 11 de março de 1973, encerrou-se em 20 de junho do mesmo ano com outro massacre, o acontecido nas redondezas do Aeroporto Internacional de Ezeiza, quando do retorno definitivo de Juan Domingo Perón ao país. A expectativa pela volta do velho líder, exilado durante 18 anos, levou em torno de um milhão de pessoas ao ato montado na rodovia de acesso ao aeroporto. A segurança do evento esteve completamente a cargo da extrema direita peronista. Quando a coluna da Juventud Peronista, formação de esquerda que incluía o movimento Montoneros, se aproximou do palco, grupos armados do peronismo e do sindicalismo de direita, secundados por militares e policiais à paisana, abriram fogo contra os militantes. O enfrentamento deixou 13 mortos e 365 feridos (MERELES, 2016, p 106). O avião que trazia Perón aterrissou em outro lugar.

Já de volta no país, Perón deixou claro seu alinhamento com a direita do movimento. Cámpora renunciou, sendo sucedido por Raúl Lastiri como presidente provisório, que chamou a eleições imediatas, nas quais venceria amplamente, em setembro, a chapa integrada por Perón e sua terceira esposa, María Estela Martínez (Isabel). Lastiri era politicamente relacionado a José López Rega, secretário de Perón e principal referente da extrema direita, que ocuparia o cargo de Ministro de Bienestar Social. A partir do ministério, López Rega organiza a denominada Alianza Anticomunista Argentina (Triple A), formação paramilitar que atuará com completa impunidade atacando ativistas estudantis e do movimento operário, bem como dirigentes de diversos partidos políticos. A Triple A integrava capangas do sindicalismo de direita, militares reformados e na ativa, e dirigentes peronistas que governavam algumas cidades e províncias. Segundo Novaro e Palermo (2011, p 81), entre os últimos meses de 1973 e o golpe de Estado de março de 1976 a Triple A cometeu em torno de 900 assassinatos.

A repressão golpeava tanto a guerrilha quanto a esquerda não armada. Alguns dos massacres em grupo mais lembrados, como o de Pacheco em junho de 1974 ou o de La Plata em setembro de 1975 foram contra ativistas de partidos tradicionais da esquerda não 
guerrilheira que apoiavam ocupações de fábricas. E havia, constantemente, ações capilarizadas que, como explica Mereles (2016, p 107), eram "llevadas a cabo de manera cotidiana en lugares de trabajo, ámbitos de militancia o barriales (intimidaciones, amenazas, atentados, delaciones, etc.), situaciones más difíciles de aprehender desde una mirada macro del problema". E também no âmbito "macro" a ofensiva era intensa: entre outubro de 1973 e o mesmo mês de 1974, o poder executivo nacional interveio em 5 províncias, afastando seus governadores, em um caso (Córdoba) substituindo-o pelo próprio chefe de polícia que o derrocou. Nos últimos meses de 1974, foi decretado o estado de sítio no país todo, que se prolongaria até 1982, já que seria continuado pela ditadura militar.

\subsection{A cidade era uma blitz}

Muitos dos que escreveram sobre aqueles anos observam que a juventude, pelo menos a das classes médias e baixas, passou a ocupar um lugar permanente de "suspeito" quando se encontrava fora de alguma das atividades para ela normatizadas, e foi objeto de vigilância em quase todos os espaços. Em setembro de 1974, López Rega e Isabel, já presidenta depois da morte de Perón ${ }^{118}$, enviam ao Congresso a lei 20.771 sobre narcóticos, que, como aponta Manzano (2014, p 422), serviu para estabelecer um "problema de drogas" e intensificar a vigilância sobre a juventude e a repressão sobre suas atividades coletivas de qualquer índole. A lei era completamente desproporcionada para um país no qual a expansão de uso de drogas era irrisória, como era exótica sua fundamentação, que chegava a sustentar que as guerrilhas agiam sob efeito de entorpecentes $^{119}$. O assédio aos lugares de encontro juvenil começou a ser tão grande que as empresas de lazer e espetáculos reclamavam formalmente ao governo. Durante essas batidas policiais, em apenas seis meses de 1975 foram detidos 1.425 jovens (ibidem, $\mathrm{p}$ 424), e o clima persecutório se instalava na sociedade como um todo:

The state-of-siege mentality along with the drug-related measures overlapped to generate a climate of "nation at war," which had young people as its targets. It was not coincidental

\footnotetext{
${ }^{118}$ Juan Domingo Perón faleceu em 1 de julho de 1974. Foi sucedido pela vice-presidenta, que governaria até ser deposta pelas forças armadas no dia 24 de março de 1976. José López Rega deixou o ministério em julho de 1975, quando abandonou o país como embaixador, mas as operações da Triple A continuaram. ${ }^{119}$ Paradoxalmente, as organizações de esquerda, sobretudo as guerrilheiras, condenavam fortemente o uso de drogas. Benedetti e Graziano (2016, p 17) lembram de uma palavra de ordem muito contundente a respeito, que entoavam setores da esquerda peronista em 1973: "No somos putos, no somos faloperos, somos soldados de FAR e Montoneros".
} 
that a group of "neighbors from Villa Crespo" in Buenos Aires and another from distant Comodoro Rivadavia wrote letters to the minister of the interior in 1975 to ask for "more safety" in their communities, which were "threatened," they both said, by young individuals identified as either "subversives or drug addicts." (MANZANO, 2014, p 424)

O relato da pesquisadora deixa perceber um outro fator, nada, desprezível, que motorizava a intensificação do autoritarismo: um setor da população começava a ver com bons olhos a repressão. Contribuía para isso a ação cada vez mais letal das organizações guerrilheiras, Montoneros e ERP, que quanto mais revezes sofriam na luta armada mais se isolavam dos movimentos sociais e se concentravam em um enfrentamento militar urbano de seus aparelhos contra os do Estado, vitimando conscritos, guardas civis e inclusive pessoas alheias ao combate (NOVARO e PALERMO, 2011, p 68-69). A resposta repressiva caia indistintamente contra tudo que fosse mobilização social.

Em um contexto como esse, o rock nacional e seus aficionados, que eram um setor minoritário, mas já considerável, da juventude de classe média urbana, e os jovens militantes e simpatizantes de esquerda, tendiam a confluir em um lugar comum de alvo da repressão. E, nessa altura, já eram setores com algumas interseções: parte do novo público do "progressivo" era também simpatizante ou militante político da nova geração pós Cordobazo, ou quanto menos colega de colégio ou de saídas. As memórias discursivas que nesse espaço se interceptavam contraditoriamente combinavam determinações ideológicas muito diferentes com um posicionamento transformador e anti-autoritário em comum.

\section{Uma elipse significativa}

Neste capítulo, em que tratamos acerca das diferentes dimensões do político no rock argentina, bem como das suas relações com as práticas socialmente identificadas como "políticas", retomamos estudos de pesquisadores parcialmente comentados em capítulos anteriores, e introduzimos outros que focalizam mais detalhadamente essa dimensão. Também apoiamos nossa reflexão na pesquisa histórica acerca da luta de classes em um período crucial da Argentina no século XX: a passagem entre as décadas de 1960 e 1970. Parece-nos adequada a ocasião para nos referirmos a um estudo recente, que atingiu repercussão considerável no meio acadêmico argentino, e cuja observação crítica pode integrar-se na nossa reflexão no plano das relações entre práticas culturais e a série de significações que, na sociedade argentina da época, circulavam em torno de 
termos como "compromisso", "definição política" ou "militância". Trata-se de um exercício antitético em dois sentidos. Por um lado, porque é um trabalho que apresenta uma visão muito diferente, quase oposta, da maior parte dos que aqui referimos. Por outra, porque há nele uma notória e curiosa lacuna precisamente em torno do "rock nacional", logo em um ponto em que a própria argumentação do autor pareceria requerê-lo. Esse último fator foi decisivo para que decidíssemos incluir, nesta tese, uma breve observação crítica sobre o livro.

Trata-se do estudo de Sebastián Carassai (2014), publicado com o título Los años setenta de la gente común. La naturalización de la violencia. $\mathrm{O}$ trabalho deste historiador e sociólogo, que foi parte da sua tese de doutorado defendida em 2012, tem o grande atrativo e originalidade de abordar os 70 argentinos focalizando algo que teria sido deixado de lado pelas práticas acadêmicas dominantes, que privilegiam a forte politização da vida naquele período. O pesquisador anuncia "Estudio aqui las clases medias no involucradas de manera directa en la lucha política de los años setenta" (CARASSAI, 2014, p 13). E o faz por três vias: entrevistas com pessoas selecionadas para rememorar a época, análise de produtos midiáticos (publicidades, humor e telenovela) e discussão de pesquisas sociológicas produzidas naquele tempo. A proposta nos interessou precisamente porque estudamos um campo da produção de bens simbólicos cujos membros raras vezes se involucraram nessa luta, e maioritariamente provinham das classes médias.

O material que o pesquisador expõe e organiza, sobretudo o que provém da mídia, se abre, realmente, a leituras de fenômenos da época aos quais tem sido dada pouca atenção. O levantamento de publicidades dos produtos cotidianos mais diversos que incluem trocadilhos com "disparos", "bombas", "matar" e outros termos e realmente surpreendente. Por ouro lado, sua hipótese de que a classe média não virou peronista nos anos 70, como sustentam outros autores, mas que já existia um setor que tinha abandonado o antiperonismo por um "não peronismo", mostra-se muito convincente, sobretudo na comparação com atitudes do auge antiperonista dos anos 50 que o livro também registra. No entanto, o estudo tem obtido avaliações muito dispares na sua própria área, visíveis nas resenhas em revistas especializadas, que vão do elogio (PALERMO, 2014) à dura crítica (CRENZEL, 2014).

Por uma parte, como aponta este último resenhista, os relatos onde se indagam o que teriam sido as opiniões dos entrevistados, e que servem de base para a conclusão de que a classe média "não militante" teria rejeitado a radicalização são relatos produzidos 
na atualidade. A esse respeito, concordamos com Sarlo (2007) sobre a dimensão anacrônica -inevitável, mas que metodologicamente deve ser levada em conta- que envolve observar o discurso de quem narra o passado a partir do presente. Verdadeiramente a reflexão de Carassai não parece tomar, por momentos, uma distância a respeito desses testemunhos de hoje que considere seu anacronismo na hora de produzir, como pesquisador, conhecimento sobre o passado. Por outra parte, na sua drástica divisão entre classe média "militante" e "não militante" localiza a primeira exclusivamente no âmbito universitário. Ao longo do livro todo, sustenta que somente os universitários, junto com setores militantes da classe operária industrial, teriam participado das intensas lutas sociais do período. Como Crenzel (op cit) destaca, deixa assim de lado profissionais liberais, docentes, religiosos, artistas, jornalistas, pequenos produtores e, acrescentamos nós, movimentos de bairros. Chamou nossa atenção que, dentre os grandes levantamentos urbanos da época (Cordobazo e Rosariazo de 1969, Tucumanazos de 1969 e 1970) esqueça precisamente o Mendozazo de abril de 1972, único cujos principais protagonistas não foram nem estudantes nem operários, mas as professoras primárias e o movimento de vizinhos pelo não pagamento das tarifas de eletricidade (RRODRÍGUEZ AGÜERO, 2014).

Porém, o que motiva, neste trabalho, nossa referência a essa obra, cujo valor em outros aspectos não negamos, são as páginas em que se realiza uma disquisição acerca de filmes e música "sobre jovens" e/ou "para jovens". Nessa parte, o discurso do pesquisador, diferentemente do resto do livro, perde notavelmente distância crítica em relação à indústria cultural:

Las representaciones de la juventud en algunos productos cinematográficos ayudan a completar el panorama del mundo juvenil de los años setenta. El cine comercial de consumo masivo, por ejemplo, reflejó la cuestión de la rebelión estudiantil, de su legitimidad y sus límites. (CARASSAI, 2014, p 100)

O fragmento citado, com o qual o autor inicia sua reflexão sobre produtos da cultura de massa, segue a uma explicação, apoiada em pesquisas de opinião feitas na época com jovens, sobre seu interesse e suas percepções na política. Já de início, então, não parece congruente que esse panorama possa ser "completado" com base na observação de produtos ficcionais, sobretudo se eles vão ser considerados como "refletindo" um real, como se a indústria não tivesse políticas culturais, e não construísse modelos conforme relações de forças. Na mesma linha, e desconhecendo tudo que a 
crítica sobre a cultura de massa na Argentina da época refletiu a respeito, refere-se aos filmes musicais que promoviam estrelas da indústria discográfica. $\mathrm{O}$ fato de eles terem atingido grande audiência (sobre o qual, aliás, não apresenta dados) seria suficiente para considera-los acriticamente como "retratos" (é o termo empregado) de realidade:

En estas películas, la juventud aparecía asociada con la alegría, la música y el baile, el anhelo de un mejor futuro o con sueños vinculados con el éxito, la fama o el amor; y en todos los casos encarnada en protagonistas que nunca aparecían asociados a la militancia política ni, por supuesto, a la violencia. En una película de 1972, incluso, la juventud aparecía retratada mientras pedía desesperadamente paz. (ibidem, p 100-101)

É interessante que o primeiro filme referido por Carassai nessa seção seja $E l$ profesor hippie, dirigido por Fernando Ayala em 1969. Tratava-se da primeira de uma série em que o veterano cômico Luis Sandrini interpretava um professor de ensino médio "compreensivo" com a rebeldia dos jovens que, como em todos os produtos da grande indústria a partir do "Club del Clan" que já referimos em capítulos anteriores, é uma rebeldia inócua, passível de ser contida pelo statu quo.

Chama a atenção, para não dizer que é insólito, que, tratando de juventude "não militante" e música nos anos 70, ainda mais com o substantivo "hippie" em presença, Carassai não se refira ao rock argentino, como, aliás, não faz ao longo do livro todo. Nas mesmas páginas menciona alguns "convencionais" ou "nuevaoleros" e inclusive passa a milímetros, pertíssimo do rock ao mencionar Sandro ${ }^{120}$, mas não parece vir à tona, sequer para ser rebatido, o que tantos dos seus colegas sociólogos e historiadores consideram como um dos fenômenos mais relevantes nas práticas culturais juvenis da Argentina daquela década. E se o autor considerava que o alcance de público do rock nacional ainda não era suficientemente significativo, poderia dizer-se o mesmo do consumo de rock do mundo, no país? A principal revista de rock, Pelo, que também divulgava rock argentino, em agosto de 1970 já vendia 45.000 exemplares por número ${ }^{121}$. Os que ocupavam as capas dessa revista, Mick Jagger, John Lennon, Jimi Hendrix, Janis Joplin, não deveriam ser vistos como um "consumo juvenil” que dissesse alguma coisa para o autor, diferente das antípodas de "pacatos" ou "violentos" que ele considera? Há como tratar de juventude pedindo “desesperadamente paz”, na década de 70, sem referir-se aos movimentos pacifistas e, com eles, ao rock? É necessário, para resgatar essa imagem, lembrar de um

\footnotetext{
120 Tratamos sobre esse cantor e suas relações de aproximação e distância com o rock no Capítulo III.

${ }^{121}$ Podestá (1970, p 36)
} 
filme praticamente esquecido, sobre automobilismo ${ }^{122}$, tendo acontecido o sucesso do musical Hair, que na sua versão argentina permaneceu três anos em um grande teatro portenho? E de fato, o próprio rock nacional, nos primeiros setenta já tinha quanto menos uma presença muito visível, embora minoritária. Passou de publicar 13 LPs em 1970 a $32 \mathrm{em} 1972^{123}$. Os recitais que começam em 1971 com o nome de Buenos Aires Rock reúnem em torno de 30.000 pessoas $^{124}$, e o segundo deles é levado ao cinema comercial, permanecendo anos em várias salas.

A incrível omissão do rock, e fundamentalmente do rock argentino no trabalho de Carassai parece ter explicação na dicotomia que o autor estabelece entre classe média envolvida ou não na luta política. Principalmente, na percepção do espaço social argentino que ele atribui aos "não envolvidos": a de uma "sociedad fundamentalmente pacífica acostumbrada a resolver sus conflitos de modo civilizado" (CARASSAI, 2014, 75). É muito visível que não há como extrair uma visão desse tipo das práticas discursivas do rock argentino, com sua forte rejeição por um funcionamento social que vê como hipócrita, alienante e repressor. Fica, então, um espaço que não se encaixa na oposição entre o "militante" e o "não militante". Um setor "não militante", mas partícipe de práticas anti-autortitarias e crescentemente "envolvido", mesmo a contragosto, na confliuosidade política, por causa da repressão que vai fazendo dele um dos seus alvos. A elipse é mais questionável ainda se considerarmos que o estudo de Carassai, diferentemente do nosso, chega até o final da ditadura militar, quando o rock nacional, já tendo adquirido caráter massivo, é palco privilegiado de manifestação contra o regime (VILA, 1985; PUJOL, 2013).

\section{Efeito de campo e anacronismo. Duas saturações da "lucha"}

No apartado anterior mencionamos os recitais "Buenos Aires Rock", que, de 1970 a 1972 foram o principal espaço de confluência das bandas do "progressivo", que já começava a alternar esse nome com o de "rock nacional". Em 2005, o departamento argentino do canal Live Music produziu um longo documental sobre a gravadora independente Mandioca, à qual já nos referimos no Capítulo II, e que foi fundamental

\footnotetext{
${ }^{122}$ Carassai se refere, no último trecho citado, a Piloto de pruebas, de Leo Fleider, filmada em 1972 e dedicada a promover a figura do automobilista Carlos Alberto Pairetti.

${ }^{123}$ Alabarces (1993, p 51).

${ }^{124}$ Díaz (2005, p 65).
} 
para que o rock argentino em gestação gravasse seus primeiros discos. Em um momento, é entrevistado Daniel Ripoll, que foi o diretor da revista Pelo, e fala sobre aquele ciclo de recitais da década de 70 . Destacamos este trecho:

(1) [los recitales de Buenos Aires Rock] Consolidaron la idea de que éramos, existíamos y que podíamos juntarnos. Y que podíamos hacer algo revelador, revolucionario, distinto y en contra de lo establecido en ese momento, que era lo peor, que eran los militares. Finalmente, el rock también luchaba por la democracia.

Parece-nos interessante o contraponto com declarações do mesmo Ripoll durante o terceiro desses recitais, o de 1972, gravadas no filme Rock hasta que se ponga el sol, de Aníbal Uset, que registrou momentos desse show:

(2) Mirá, yo creo que la síntesis de todo esto puede parecer como si fuera una lucha para tratar de imponer un tipo de música, pero más profundamente es la lucha de toda una generación para expresar cómo piensa y lo que quiere del país y de sí mismo; creo que eso es lo fundamental.

A contraposição "militares" / "democracia" que aparece no trecho (1), de 2005, é um claro exemplo do anacronismo que mencionávamos no item anterior como inerente à rememoração do passado. A dicotomia posta é própria dos processos de transição que, na década de 1980, encerram, na América do Sul, os regimes militares; uma polarização entre "ditadura" e "democracia" que regula fortemente o discurso político projetando-se até o presente. É por essa memória, que é discursiva e não documental, que é tomado o enunciador na fala, em 2005, desse ex protagonista do campo do rock. Na Argentina dos primeiros 70, embora boa parte do tempo se vivesse sob governos militares, "imperialismo", “opresión”, "explotación” encontravam suas antíteses em termos como "revolución", "liberación" ou "poder popular", como mostra todo o material que revisamos na nossa pesquisa. A fala de Ripoll em 72 (trecho2), diferentemente, encontra suas condições de produção nas práticas em torno das quais o campo se delimitava, no quadro mais geral de politização e de pré-construídos sobre necessidades de transformação social. Quando, na construção adversativa, Ripoll tenta situar essa "lucha" em algo exterior ao campo, faz essa passagem a partir de uma representação etária ("la lucha de toda una generación") que se abre a um objeto de interesse coletivo mas acaba fechando-se sobre a própria identidade ("lo que quiere del país y de sí mismo”). 
Como vimos no item 3 deste capítulo, a solicitação de "definição" política que se fazia mais intensa na Argentina dos primeiros setenta foi direcionada muitas vezes aos músicos e, na maioria dos casos, respondida com fórmulas que, palavras mais ou menos, realizavam um percurso argumentativo análogo ao que vemos no Ripoll jovem. Não é em vão que Provéndola, como já referimos naquele item, avalie que os roqueiros se inclinavam por um ideal "de cambio interno e instrospección privada". Ele cita, no seu livro, várias declarações desse tipo, de diversos músicos. Nelas, aparecem giros argumentativos que, como o que vemos em Ripoll, lembram o deslocamento "em direção a si" que observamos profusamente nas canções em capítulos anteriores.

Vemos essas argumentações de "introspeção privada" como indicadores da repetibilidade de um "modo de dizer" (SERRANI, 1994, p 83 ${ }^{125}$ ) na medida em que funcionam como resposta a um questionamento explícito e imediato, sob a representação do que se considerava uma "definição ideológica" premente. Mesmo no caso de que nosso corpus tivesse sido formado principalmente com depoimentos dos artistas sobre sua participação na vida pública, tentaríamos ler esses depoimentos para além da sua argumentatividade no intradiscurso, na tentativa de expor sua inevitável politicidade. Neste trabalho, nosso foco tem estado muito mais no discurso na própria canção e sobre ela, e é com essas práticas como objeto de estudo que apresentaremos, nos próximos dois capítulos, uma tentativa de interpretação sobre como o real social e político foi afetando, de modo não transparente nem cronológico, a regularização discursiva que temos tentado captar nos anteriores.

\section{Entrando na consternação}

Refletimos, no Capítulo IV, sobre diversas filiações discursivas que tinham se interceptado no "progressivo" argentino: os ecos do existencialismo desconfiado e cético, seu deslocamento parcial para um humanismo com um imperativo de compromisso e de mudança, traços de espirirtualismo, e até irrupções pontuais de perspectivas que parecem relacionadas aos discursos de sucesso para o jovem em um funcionamento capitalista modernizado. Postulamos e sustentamos ao longo das nossas análises que, dentro desse embate contraditório, houve um predomínio do humanocentrismo apoiado em préconstruídos sobre a necessidade de uma transformação geral do funcionamento social e

\footnotetext{
${ }^{125}$ Serrani denomina assim um tipo de ressonância discursiva, como efeito parafrástico dado pela repetição,
} em enunciados diferentes, de determinadas construções semântico-enunciativas. 
da cultura com necessária passagem pela transformação do indivíduo, que dá base às configurações do que temos denominado "mudança crítica". Porém, todos esses componentes contraditórios nunca estiveram "sozinhos" nas condições de produção, isolados no seu embate ideológico: a ordem sócio-econômica, política, educacional e cultural questionada de diferentes maneiras por todas essas filiações também sempre esteve e, conforme a relação de forças, produziu efeitos. Assim, das próprias figurações estabelecidas no primeiro rock argentino, das suas topografias para o deslocamento e "sair" libertador, do direcionamento a si próprio, das cronografias do amanhecer, algo começará a perturbar. Algo que vemos como uma nova condensação de acontecimentos discursivos, que aponta para uma desestabilização do já regulado.

Para Terán (2008, p 291), no inícío dos 70, o encarniçamento da confrontação política é congruente com uma “crispación” do discurso. Pujol (2007, p 320) emprega uma imagem especialmente adequada para o que veremos daqui em diante: "La aurora del 73 tenía un peligroso reverso, un fondo negro que, retrospectivamente, hoy se puede ver en términos dramáticos." Nossa observação do rock argentino nos leva a localizar, no seu discurso, um processo que denominaremos "consternação", por como esse termo articula o espanto da crispação com um pesar profundo. Nos capítulos que seguem ilustraremos uma busca, na voz e nas imagens de uma série de canções, desse modo como a crescente violência opressora foi ganhando forma no conflito discursivo. 


\title{
Capítulo IX \\ Canciones del cielo final
}

(Terceiro percurso)

\begin{abstract}
Señoras y señores, jóvenes de nuestra generación, estamos para crear la ilusión y aquí podrán ver a los miles de ciegos, aquí podrán sentir los detalles del dolor, aquí verán la ilusión de lo que nunca vieron.
\end{abstract}

Señoras y señores, jóvenes de nuestra generación, aquí podrán tocar la sangre de sus muertos.

Rubén Santillán ${ }^{126}$

Escutar "Soy del sol”, de Manal, pode dar a impressão de ter entrado na festa de uma comunidade hippie, e, sobretudo, causa um estranhamento para quem está acostumado com essa banda pioneira. Nem sinais de blues ou de rock duro. Percussões sem bateria, e a guitarra de Claudio Gabis com som indiano, na linha de "fusão" que esse músico praticou várias vezes naqueles anos. A própria voz de Alejandro Medina, autor da música, soa menos grave que em outras gravações e interrompe o canto com quase risos. O que a voz canta também não se assemelha às narrativas de mudança. O locutor que a voz põe em cena se descreve em um puro estado, não há movimento nem procura. Nada precisa mudar porque o estado é de graça "tengo paz y calidez; quiero amor y tengo fe". E é resultado de algo acontecido, mas de algo em que não houve agentividade, simplesmente o homem foi "atrapado" por delírios e enxames gozosos.

Porém, há algo nefando em um lugar aonde é possível ir. Deslocar-se leva junto dos que não querem luz. O canto começa com a declaração "soy del sol”, e imediatamente anuncia um "não querer saber", estranho nas perspectivas dos enunciadores do primeiro rock argentino em relação ao conhecer. A música foi gravada no último disco de Manal, “El León”, que apareceu em 1971 com a banda já separada. Não a trazemos aqui porque pensemos que seja uma peça representativa exatamente do que vamos expor neste percurso, ela é festiva demais para isso. Interessou-nos seu alvoroço como manifestação

\footnotetext{
${ }^{126}$ No panfleto de uma montagem dirigida por ele em 1981, baseada em Pompas Fúnebres, de Jean Genet. A apresentação seria no dia 25 de março, e o panfleto incluía as frases "Aniversario" e "Aquí cayó un joven". A peça foi cancelada por ameaças contra o teatro. Texto registrado em Cocco (2011)
} 
de entusiasmo, mas também de inquietação, que chama a permanecer ali onde se está, prazerosamente amarrado.

Neste capítulo apresentaremos o que consideramos uma desregulação parcial da regularização que nos ocupou nos capítulos anteriores. Consideramo-la como parcial porque, em termos de Pêcheux ([1983] 2007, p 82-83), o jogo de forças entre a regularização pré-existente e os novos acontecimentos discursivos não produz uma transformação integral, e porque vários dos elementos já dados na regularização que temos descrito reaparecem recursivamente no mesmo momento, e inclusive em etapas bem posteriores do rock argentino, que este trabalho não inclui. O que principalmente cremos que resulta perturbado são os implícitos ou pré-construidos relacionados à necessidade de mudança, que começam a conflitar com pré-construidos de preservação. Que a ordem de coisas dadas não satisfaz continua sendo um implícito, até reforçado, mas tudo que se relaciona ao deslocamento se vê afetado. Algumas regularidades relativas à topografia e ao movimento e perspectivas dos seres representados em cena, que iremos descrevendo, marcam uma diferença em relação ao "sair" e ao desfazer-se do que já está dado, traços que, como expusemos em capítulos anteriores, funcionavam como um imperativo. Permanece a centralidade do ser em relação ao entorno, bem como a euforia do direcionamento para si, mas, por uma parte, aparecem mais personagens coletivas e, por outra, o vínculo com o entorno é dito com diferentes graus de inquietação ou de angústia. $\mathrm{O}$ dizer proverbial míngua, embora não esteja ausente, e a fixação das perspectivas é mais instável, sobretudo no que diz respeito à oposição eufórico/disfórico.

Organizaremos este capítulo em quatro blocos. Os três primeiros correspondem a diferentes aspectos do que denominamos "consternação". O primeiro está centrado na topografia e nos deslocamentos, o segundo em diferentes modulações emocionais e o terceiro na figuração do homem armado. No quarto não trabalhamos com nenhuma composição, mas com o poema "Ezeiza", publicado em 2003 pelo escritor argentino Fabián Casas. A partir dessa poesia, que alude nitidamente à violência armada da década de setenta e instala uma perspectiva de quem era criança na época, enunciaremos nossa proposta de um "saber da retirada" como uma das posições de sujeito que atravessam os acontecimentos discursivos dessa fase da regularização do primeiro rock argentino. $\mathrm{O}$ saber sobre a privação que caracteriza essa posição, e que explicaremos a partir de determinadas imagens desse poema, dará a passagem para o capítulo seguinte, o último desta tese. 


\section{O quarto, o muro, bajo otros cielos}

Depois da separação definitiva de Los Gatos, dois de seus membros, o guitarrista Alfredo Toth e o tecladista Ciro Fogliatta, fundam a banda Sacramento, de breve existência. O seu único disco, publicado em 1972, dentre suas onze músicas inclui uma chamada "Reunidos en el cuarto". Com mais elaboração do que em Los Gatos, inclusive considerando sua última etapa, a composição lembra o tipo de hard rock que na época fazem bandas como Deep Purple.

O canto se inicia dando voz a um apresentador que, em uma $1^{\mathrm{a}}$ pessoa do plural, situa uma cenografia específica, que dominará a canção inteira: “Aquí estamos, reunidos en el cuarto". A representação dos deslocamentos e propósitos mostra uma tendência quase oposta à que temos visto a partir de "De nada sirve", "La balsa", "Hoy seremos campesinos", "Final" e outras que abordamos no Capítulo IV. Em primeiro lugar, a desorientação parece ter substituído o propósito, dado que estamos, mas "sin saber dónde estar". O estar no espaço fechado, sem sair, também não parece identificar-se com a situação disfórica de tédio que vemos em "De nada sirve". A casa é um espaço para dividir coletivamente, e para escapar, fuga que não parece ser "de uno mismo" nem da "soledad interna". O projeto de "naufragar" (“dejaste de vagar") parece ter sido mudado, "sem saber", pela tentativa de fugir de algo.

A topografia do quarto começa a ganhar força no "progressivo" argentino nos primeiros anos da década de 70. Na etapa que, neste trabalho, observamos com minuciosidade, até 1971, ela é praticamente inexistente, como a própria série lexical que pode materializá-la ${ }^{127}$. Só aparecem duas menções desse tipo de lugar. Uma em "Ayer nomás", de Moris e Pipo Lernoud, e apenas como um dos espaços de desapontamento com o acontecer de um locutor-dissidente, que não é retomado posteriormente na música:

Hoy desperté,

y vi mi cama y vi mi cuarto, ya todo es gris y sin sentido,

${ }^{127}$ No espanhol argentino, "cuarto" ou "pieza". 
la gente vive $\sin$ creer.

A outra é "Ana no duerme", de Almendra, uma das músicas que integram o disco que analisamos no Capítulo V. E trata-se de um "quarto" completamente fora do ordinário não na sua descrição, já que não é descrito, mas na sua integração espacial na cenografia, sobretudo por certa indistinção entre interior e exterior. Na música mais convidativa ao movimento corporal daquele disco, o quarto é o lugar onde Ana, que não dorme, vive seu deleite extático com a luz e a sombra, e de onde domina a visão da cidade e pode chegar a acordar "sobre el mar".

Porém, os quartos que aparecem com certa frequência neste segundo período começam a ser tratados como refúgios ou, conforme o caso, como clausuras, mesmo nas canções mais intimistas, sem aparente remissão a qualquer dimensão supra-individual. Em 1973, por exemplo, a dupla Vivencia publica seu segundo LP, denominado Mi cuarto, que reproduz, na capa, um dos quadros que Van Gogh pintou sobre sua habitação em Arles. A música mais famosa do disco, uma canção folk, tinha o mesmo nome, e alcançou, em uma audiência adolescente, um sucesso que a dupla não voltaria a experimentar. $\mathrm{O}$ quarto é também recorrente na banda mais renomada das que surgiram naquela época: Sui Generis, sobre a qual trataremos no capítulo seguinte, voltando inclusive sobre a figuração dessa parte da casa. Na "vida nas esquinas" que Moris exaltava em "Muchacho", como vimos nos capítulos IV e VI, a casa podia estar dormida e não saber. Não ter uma casa podia ser uma das descobertas do renascer, como em "Porque hoy nací". Nos 70, não apenas os quartos a as casas vêm limitar o gozo do espaço aberto. Também, como veremos, outras figurações, mais perturbadoras, cumprem esse papel.

Uma das composições mais originais e inquietantes nesse sentido é "Nos encontraremos en alguna parte", gravada em 1971 no único LP publicado por La Cofradía de la Flor Solar. Há poucos registros sonoros dessa banda, apesar de que vários dos seus músicos tiveram depois uma carreira muito expressiva. Kubero Díaz, Jorge Pinchevsky e Isa Portugheis tocaram com La Pesada del Rock'n Roll, e também foi a Cofradia o primeiro grupo de Skay Beilinson, Mono Cohen e Carmen Castro (La Negra Poli), futuros integrantes da banda argentina mais escutada das décadas de 80 e 90, Patricio Rey 
y Los Redonditos de Ricota, mais conhecida como Los Redondos ${ }^{128}$. La Cofradía era só parcialmente uma banda de música, antes que tudo era uma comunidade de tipo hippie, de pessoas que conviviam no mesmo espaço e tentavam produzir sua própria subsistência. Havia entre eles artistas plásticos, artesãos e, também, músicos (GOBELLO, 1999, p 2427). Eram da cidade de La Plata, capital da Provincia de Buenos Aires. A casa coletiva onde habitavam chegou a ser também lugar de visitação para músicos de Buenos Aires e jornalistas ligados ao campo do rock. O disco foi gravado quando ainda a vida na casa era relativamente tranquila, apesar de hostilizações ocasionais. Mas, no início de 1974, a situação de La Plata muda radicalmente. O governador é obrigado a renunciar e assume o vice-governador, Victorio Calabró, relacionado a López Rega e à Triple A. Assim, o processo de generalização do terrorismo de Estado que descrevemos no capítulo anterior teve particular intensidade em La Plata, e a existência de uma comunidade com essas características se torna inviável. La Cofradía de la Flor Solar, como comunidade, se dissolve naquele mesmo ano. Como formação musical já não tinha regularidade, embora os músicos que passaram por ela continuavam tocando em outros grupos.

A música "Nos encontraremos en alguna parte" foi composta por Kubero Díaz, quem é também a voz principal e o guitarrista na gravação. Boa parte dos três minutos e meio que dura a gravação são instrumentais, com grande protagonismo da guitarra elétrica. Díaz era considerado um Hendrix argentino, e realmente algumas partes da música lembram "solos" daquele músico estadunidense. No entanto, na parte cantada a voz passa a ser protagonista. O primeiro que nos chama a atenção é a passagem entre o segmento vocal e a continuidade do instrumental: o último verso cantado, "silenciosamente proseguí", pode ser visto como metadiscurso sobre a própria execução musical. $O$ fato de ser a única aparição da $1^{a}$ pessoa do singular reforça essa hipótese de deslocamento da perspectiva e da voz para a própria cena da performance, que nesse momento, como cantar, entra em um certo silêncio, já que dá lugar à guitarra para “prosseguir". Lemos, nesse deslocamento, o anúncio de uma necessidade de calar, ou, mais exatamente, de continuar sem verbalização, que nos parece adequado ao que vem sendo construído na letra e no canto.

\footnotetext{
${ }^{128}$ Poly e Cohen não foram, a rigor, músicos de Los Redondos. A primeira foi produtora e o segundo, com o pseudônimo de Rocambole, fez a arte dos encartes de todos os discos.
} 
Há dois momentos no que se canta, que podem corresponder a duas estrofes, com simetria na melodia e em quase toda a métrica:

\begin{tabular}{|l|l|}
\hline $\mathbf{1}^{\mathbf{a}}$ parte & $\mathbf{2}^{\mathbf{a}}$ parte \\
\hline $\begin{array}{l}\text { Como antiguas aves naciendo a la vida } \\
\text { bajo ciertos cielos muchas veces vamos }\end{array}$ & $\begin{array}{l}\text { Pero, sin embargo, como a hurtadillas, } \\
\text { a encontramos, a cantarnos. }\end{array}$ \\
$\begin{array}{l}\text { vamos a encontrarnos, tomarnos las manos. } \\
\text { Ahora la vida se esconde en sombras } \\
\text { por detrás de vieja construcción. }\end{array}$ & y vemos morir a muchos amigos \\
& Silenciosamente proseguí. \\
\hline
\end{tabular}

O canto põe em cena um "nós", mediante uma construção comparativa que tende a caracterizá-lo como coletivo de iguais. O deslocamento é também um novo nascer, como nas cenas de mudança crítica que vimos no Capítulo IV, mas relacionado com o encontro e o canto coletivo. Os céus são aqui um teto, o voo é por baixo deles. A cronografia não é a do amanhecer, nem o sol espera: agora -antes não- a vida se esconde em sombras, e alguma construção antiga pode servir de refúgio.

Na segunda parte o canto sobressai mais, já que a guitarra elétrica soa com menos volume do que na primeira, acompanhando, no início, apenas com um ponteio. Nesse bloco, há uma nova referência a encontrar-se, mas com uma comparação bem diferente, quase antitética. A locução adverbial "a hurtadillas" aponta para um deslocamento furtivo que pareceria incompatível com o voo de uma ave. E, além de um movimento oculto, insinua uma diminuição da própria percepção: "a hurtadillas" é também um modo de olhar com dissimulo. A ameaça prefigurada na primeira parte ganha aqui a forma de um acontecer desagentivizado, "se nos golpea", e imotivado, já que "sucede", como obedecendo a um princípio inevitável. Assim, amigos morrem e o cantar continua individual e silenciosamente.

"Vemos morir a muchos amigos" dificilmente poderia ser enquadrado, na Argentina de 1971, como uma modulação exatamente testemunhal. A violência repressiva tinha dado lugar já a algumas mortes, principalmente em manifestações e em ações armadas isoladas, mas, ainda, salvo raros casos, não tinha surgido do inesperado para prender e matar, como aconteceria pouco depois. Porém, não precisava estar acontecendo: o enfrentamento crescentemente encarniçado delineava isso como uma das 
suas possibilidades. Também as canções de protesto da época, é claro que com uma construção de objetos e uma orientação dialógica completamente diferente, cantavam mortes de combatentes ou de simples vítimas desarmadas. O que indagamos aqui é a ocorrência deste tipo de figurações em um campo da música popular relativamente distante da visão de mundo das organizações revolucionárias, distância perceptível em vários traços da música que estamos abordando: a despersonalização do agressor, a topografia socialmente desenraizada, o propósito da "bandada de aves" e da voz, que não é outro que "nascer" a uma nova vida. E indagamos, sobretudo, que uma figuração de seres "especiais", irmanados por um propósito desse tipo, comece a incluir a ameaça, a devastação. Que ela guarde continuidades com figurações semelhantes no mesmo campo da produção musical, e também descontinuidades -como a própria devastação e os refúgios, encerros, movimentos furtivos- que mostram algo sendo perturbado. Assim, vemos esta canção, e todas as que abordamos nesta seção, como figurações, com maior ou menor tentativa de verossimilhança, em torno de aspirações que se veem obstruídas por um real cada vez mais cruento.

Duas músicas de Aquelarre ${ }^{129}$ gravadas entre 1972 e 1973 mostram também descontinuidades com o que vinha sendo dominante no rock argentino, principalmente no que diz respeito ao deslocamento, às mudanças dos seres postos em cena e ao tratamento de objetos como o céu, o sol e a luz. A primeira a que nos referiremos é "Iluminen la tierra", publicada no LP Candiles. A composição tem claramente duas partes, sendo a segunda predominantemente instrumental. O início lembra uma zamba, gênero folclórico da Argentina e do Chile, para passar logo a um ritmo mais próximo do blues.

No começo do canto, a voz dá corpo a dicções calmas, separadas entre si por um golpe da bateria. Primeiro uma sílaba, depois três, depois dois grupos de quatro : "Sol / ese sol / ¿dónde está? ¿dónde va?”. A pergunta que segue, com o mesmo ritmo, sobre se o sol "se perde", vai construindo uma figuração que parece uma antítese de músicas que vimos nos capítulos anteriores, uma verdadeira "despedida" do sol onipresente nas narrativas de mudança crítica. Não é o sol que espera o náufrago livre, mas o homem que

\footnotetext{
${ }^{129}$ Banda formada em 1972 por dois ex Almendra, o baixista Emilio del Guercio e o baterista Rodolfo García, junto com o guitarrista Hector Starc e o tecladista Hugo González Neira. Duró até 1977 e publicou 4 LPs e um compacto. São considerados como um grupo de música muito elaborada, e na escuta se percebe uma aproximação do jazz, campo no qual Del Guercio entraria de cheio posteriormente. Na informação de encarte dos discos da banda, a autoria das composições é explicitamente atribuída a todos os membros.
} 
espera trás um muro. Crê que o sol virá, mas desiste da espera. Na continuidade do canto, ancorado em um presente que se descreve sem luz, o vento domina a topografia. A presunção de que a desolação dure muito tempo é congruente, do nosso ponto de vista, com a presença da zamba na materialidade musical da parte vocal da música e nos últimos segundos do encerramento instrumental. A entrada, no progressivo argentino, de uma cronografia de espera desesperançada lança mão, assim, de uma tradição musical que a comporta amplamente. "Iluminen la tierra" é também uma das poucas composições das primeiras épocas do rock argentino em que se propõe como "saída" um retorno, começar de novo.

A outra música de Aquelarre, "Violencia en el parque", gravada em um compacto, é provavelmente a mais conhecida da banda. Segundo Provéndola (2015, p 80), depois do sucesso do compacto seria gravada em Candiles, mesmo LP da que acabamos de comentar, mas foi vedada pela censura ${ }^{130}$. Canção de letra algo críptica, não é de estranhar que seu título ou alguns fragmentos tenham colocado em alerta censores e repressores precisamente porque, se não é óbvia, também não é dissimulada. Cremos que se trata de uma música que põe em cena dimensões individuais e coletivas que não correspondiam à expectativa de "canção politizada" da esquerda revolucionária nem, portanto, à daqueles dispostos a reprimi-la. Longe de ser uma música com uma chave para elucidar -prática que também não era comum na Argentina da época, em que o político tendia a saturar sua determinação- ela envolveu imagens facilmente relacionáveis à luta política, mas para um tipo de conflito articulado indistintamente no singular e no coletivo, e não especificado mais que em torno da liberdade como força.

"Violencia en el parque" instala um locutor com traços de enunciador proverbial, que interpela um "tu" cuja especificidade varia ao longo da música. Na descrição do início, "violencia" e "terror" se situam em espaços heterogêneos, dentro e fora da cidade: o parque e as estradas. Na sequência, o ser interpelado aparece em uma relação com o entorno que lhe permite corporizar a inquietação: a violência e o terror tornam suas mãos

\footnotetext{
${ }^{130}$ A informação nos produz algumas dúvidas sobre o alcance dessa censura. Na lista de proibições do Comité Federal de Radiodifusión (COMFER), "Violencia en el parque" aparece como censurada só anos depois, em 1979, plena ditadura de Videla (YACCAR, 2015). Por outra parte, Provéndola não dá informações institucionais específicas sobre o ato de censura, e há registros confiáveis de shows em 1974 e em 1975 em que a música era executada ao vivo. Tendemos a interpretar que, como aconteceu com outras produções naqueles anos, mais do que uma proibição explícita houve "recomendações" para pressionar a gravadora. De fato, Candiles não incluiu essa faixa, o que do ponto de vista comercial parece estranho, já que era o grande sucesso da banda.
} 
em fogo. A palavra "mañana" dá a passagem para uma prospecção futura, em que o "tu" aparece em um deslocamento relacionado ao despertar. Na figuração, é um grito ("natural") o propulsor desse deslocamento. Seguem imagens em que elementos do entorno, como o parque e os céus (de bruma) se vinculam a partes do corpo do ser representado em uma centralidade do ser harmônica com o que vimos no Capítulo VI sobre "prosopopeias": no parque os pés "se conocen", os céus vão sarar nos lábios. O grito, fogo, águas que podem arrastar, e a própria violência aparecem como fontes de vitalidade para o "tu", dando assim passagem para o segmento mais instigante da canção, o único com continuidade rítmica e que atua como um refrão:

Quién te puede, quién te puede parar

cuando el ave sopla luz de libertad.

Todos juntos están en el parque

cantando canciones del cielo final.

A segunda pessoa se torna genérica nesse refrão, deslocando também nessa direção o lugar do enunciador. A interrogação retórica "quién te puede parar", é especialmente desafiante se pensada em uma conjuntura em que há forças, e violência, tentando "parar", e outras tentando impulsionar. Ainda mais com a repetição inicial, no canto, "quién te puede", que no espanhol oral da Argentina é parafraseável como "quem vence tua resistência", "quem te curva". Mas, que violência é essa do parque? O que é esse coletivo de "todos" que ali estão?

Na Argentina, "el parque" não é "la plaza". Dificilmente o termo "parque" evoque um espaço de mobilizações populares. O modo como a música denomina o coletivo, "todos juntos", devido a sua pouca saturação, também não parece articular-se facilmente no discurso dos movimentos de luta dos setenta, propensos à explicitação da identidade que reproduziam. Ele pressupõe uma possibilidade prévia de representar um coletivo, o de quem pode ter uma relação com o entorno vital como a que enunciador propõe ao "tu", ou a voz propõe ao corpo da escuta. "El parque" denominava, sim, na época, um lugar semanal de reunião e encontro de roqueiros, e, na letra, "todos juntos" ali estão, precisamente, cantando. Desde 1972, vários parques de Buenos Aires, principalmente o Centenario, mas também o Lezica, começaram a ser ponto de encontro dominical de roqueiros, músicos e público, para intercambiar discos, tocar em pequenos grupos, 
oferecer revistas mais ou menos subterrâneas, conhecer-se. Com frequência cada vez maior, a polícia fazia blitz ou prendia alguns.

Enfim, "parque" podia estar mais perto dessas ressonâncias do que dos palcos de luta, como também podia remeter à violência no espaço público de modo geral. O que resulta interessante na música é que, apesar disso e da focalização de um acontecer individual em interação com objetos da natureza, a remissão ao confronto manifestamente político não se perde. É que a canção não deixa de relacionar a violência à procura de liberdade. A interrogação sobre se é possível “(nos) parar” já não apenas se abre a todo aquele que é reprimido -jovem, roqueiro, militante, furtivo-, como também traz a sombra do que podem chegar a fazer para nos parar. Assim, "terror en las rutas hay" é congruente com que, no parque, se cantem "canciones del cielo final", de um risco que se percebe como último.

A partir das músicas que observamos nesta seção começamos a expor o que nos parecem diferenças em relação às configurações de objetos, cenografia e perspectivas dominantes no primeiro rock nacional. O quarto, o encerro, a desorientação de propósitos, um certo abandono do "vagar" náufrago, a ausência do sol, os muros, as irmandades furtivas de novas entidades coletivas, a percepção de uma ameaça como parte dos supostos, de modo mais evidente, como em "sucede que se nos golpea", ou naturalizada pelo funcionamento da língua, como em "cielo final". Sobretudo isto último, a percepção de ameaça, por dizer respeito aos pré-construídos e saberes a partir dos quais se fala, parece-nos que vai dando lugar a uma posição de sujeito que atravessará desigualmente e em contradição com outras o dizer nesse rock argentino. De que regiões do interdiscurso fala esse sujeito? A princípio, cremos que do mesmo acervo "humanocêntrico", mas que ele precisa de uma representação sobre a luta e sobre o inimigo que se aproxima da que existia na dimensão ideológica das esquerdas. Algo disso se percebe, por exemplo, em "Violencia en el parque". No modo de semantizar a violência nessa música parece ativarse um componente do arsenal ideológico existencialista muito mais caro às esquerdas do que aos roqueiros, o compromisso como "exercício da liberdade a partir dos fatores que a ela resistem" (SILVA, 2013, p 38). É claro que isso não quer dizer que reproduza seus discursos, já que essa representação da antinomia entra em contradição produtiva com todo o resto da dimensão ideológica já assentada no campo. Do nosso ponto de vista, e como iremos expondo, a coincidência na visão da luta e do inimigo vai deixar ouvir um 
saber sobre a ameaça que dialogará em silêncio -isto é, mais pelo inferido do que pela repetição- com os setores juvenis que se envolvem na ação política e reivindicativa.

Nunca é suficiente insistir em que esse processo dentro do campo do rock argentino se apresenta de modo extremadamente contraditório. O saber sobre a ameaça também interage com o pessimismo desconfiado que interveio nas primeiras delimitações do campo, embora não impedisse o desenvolvimento de narrativas positivas sobre a mudança crítica. E essa confluência entre o mais cético e a percepção de ameaça dá lugar a figurações de um terror aleatório, e a modulações de um certo cinismo, como veremos no item seguinte.

\section{O acaso, o pânico, o riso}

Voltaremos aqui ao começo do canto em "Cementerio Club", de Luis Alberto Spinetta, sobre o qual tratamos no Capítulo III: “Justo que pensaba en vos, nena, caí muerto". Naquele ponto o caracterizamos como uma concomitância não isenta de desdém, dada fundamentalmente pela vocalização no canto e pelo marcador "justo que". Não por pensar em "vos" é que caí morto, apenas aconteceu logo enquanto pensava.

No contexto do que estamos tratando neste capítulo, abrimos a possibilidade da leitura de outra concomitância, localizando o foco dialógico do enunciado não no primeiro membro, mas no segundo; não na série dos pensamentos, mas na das mortes: "logo, ao acaso, sobrou para mim cair morto". Gente cai morta da maneira mais inesperada, desta vez fui eu, que pensava em você. Novamente, não estamos propondo uma leitura testemunhal, precisamente a relação com o acaso afasta a formulação de um lugar de dizer de testemunho. O que apontamos é que o morrer e ver morrer se torna cada vez mais dizível, mesmo em chave de absurdo. No mesmo disco de Spinetta, Artaud, lançado em 1973, na composição "Cantata de puentes amarillos" ouvia-se "Con esa sangre alrededor, qué es lo que puedo yo mirar. La sangre ríe, idiota, como esta canción”. Leituras posteriores dentro do jornalismo especializado do campo teimavam em ver nesses versos uma alusão à violência política, intenção que Spinetta insistentemente desmentiu (BERTI, 2014, p 93), inclusive quando, depois da ditadura, isso podia lhe render capital simbólico. 
Pouco antes, no final de 1972, Caludio Gabis, ex integrante de Manal, lança o disco Claudio Gabis y La Pesada del Rock'n Roll. La Pesada... era uma formação não permanente, conduzida pelo cantor e compositor Billy Bond, com propósito experimental e relacionada fortemente à gravadora Talent, continuidade de Mandioca, dirigida, como a anterior, pelo editor Jorge Álvarez. Muitos dos músicos mais reconhecidos da época gravaram com essa agrupação, No caso de Gabis, foram dois LPs. No primeiro deles, aparece a música "Blues del terror azul".

Trata-se de uma música que impressiona vivamente pelo pateticismo, muito mais intensa para a escuta do que as outras que abordamos neste capítulo. Dramaticidade quase pura nos primeiros minutos, a voz praticamente declama como se estivesse sozinha no palco, com os instrumentos dando um fundo que poderia ser o de uma peça que os incorpora como acompanhamento. Só depois de três minutos, quando toda a letra já foi cantada uma vez, os instrumentos (guitarra elétrica, baixo e bateria) ganham mais destaque, sobretudo a guitarra do autor da música, que realiza um extenso "solo". Do início, o canto quase em alarido do intérprete e baixista Alejandro Medina dá corpo a alguém que anuncia seu medo de sair, de ver amigos, de falar, de perder sua liberdade. Conta sua impossibilidade mesmo de dormir, temendo que "ellos" cheguem à sua porta. As frases são curtas e com um léxico corriqueiro, o que, combinado com o tom estarrecido da voz, contribui para a comoção na escuta.

A estruturação da letra é uma série de exclamações sobre o tempo que já dura o medo: "Cuánto hace que no salgo...”, "Cuánto hace que no duermo...”, "que no hablo", "que no escucho gritar". O ponto inicial parece ser a chegada das sombras e do "terror azul", o estado de pavor se estende desde que eles "reinam" sobre a cidade. O ser não declara apenas seu próprio medo, também que as pessoas já não riem nem se olham. Apesar de o terror pairar sobre todos, a organização do som, da declamação e do que nela é dito tendem a construir um drama individualizado. Há um status diferente para o que fala na $1^{\text {a }}$ pessoa, dado pela capacidade de se manter "verdadeiro":

Cuánto hace que no escucho gritar,

gritar con sinceridad

Lo que sienten de este miedo. 
E a voz está, precisamente, gritando o que os outros sentiriam, mas não gritam. $\mathrm{Na}$ gravação original, justamente o verso "lo que sienten de este miedo", cantado duas vezes em continuidade, está distorcido com ecos, como se o silêncio em torno requeresse sua multiplicação. O arranjo de voz que no encarte aparece como "coros" também contribui para essa focalização singular: a voz de Billy Bond acompanha a principal urrando, em vários momentos, um “uh” fantasmático que sugere um pesadelo ou um delírio.

Enfim, um cantar de pavor pela repressão nitidamente atribuída a um poder que "reina" sobre um todo social vai fechando-se em torno de um locutor que tem algo dos traços de visionário que, em capítulos anteriores, referimos como frequente no rock do mundo todo. A dificuldade de conceber um corpo coletivo se vê inclusive no modo sinedóquico como se representa as pessoas: olhos, bocas.

Quem observa a Argentina de 1972 mediante aquilo que o registro histórico destaca provavelmente fique desconcertado ao ver que uma canção como esta aparecia naquela conjuntura. Gente sofrendo um terror generalizado e paralisante não parece congruente com o momento, que foi justamente o ápice do crescimento e expansão do ativismo político e das grandes mobilizações e ocupações. E destoa das canções de incitação à luta que percorriam o país em outros gêneros. Porém, azul era a cor da polícia que patrulhava as ruas de Buenos Aires, e as mesmas fontes históricas, inclusive da história do rock, não deixam dúvidas de que os abusos policiais podem ter posto mais de uma pessoa em estado de pânico e desconfiança. O problema parece ser, então, o que focalizava cada olhar. Talvez dois ou três anos depois, "Blues del terror azul" teria harmonizado mais com as percepções generalizadas. Porém, não se trata de capacidade premonitória, mas do que determinado posicionamento e visão tendia a combinar artisticamente, em um gesto de verossimilhança e dramaticidade raro no gênero. A relação contraditória entre as diferentes posições de sujeito que atravessam o rock argentino na conjuntura dá lugar a uma síntese autocentrada do terror que estaria fora do dizível nos campos de produção de bens simbólicos em que a "definição" e a explicitação do compromisso político vai ganhando espaço, como os da música de protesto ou o cinema militante, em auge nesses anos.

Cremos que é interessante observar, não como "fonte autoral" mas como reformulações tomadas por condições de produção que vão mudando, depoimentos do autor, Claudio Gabis, em diferentes momentos históricos, sobre esse blues. Em 1974, em uma entrevista com o crítico Miguel Grinberg, o músico traz à tona essa composição 
quando está tratando sobre o que vê como uma necessidade humana, em um raciocínio de corte espiritualista:

El hombre precisa... la raza humana para dar ese paso que debe darlo de una vez por todas porque si no -como todo en el Universo lo enseña- se va a morir, va a desaparecer porque no consiguió pasar a otro nivel, a otro grado de la energía... el hombre precisa otro alimento, el hombre precisa espíritu... amor, conciencia, luz, precisa salir de la tinieblas. ¿Te acordás de ese tema que grabé en el disco, del terror azul? "El blues del terror azul" es el blues de la represión, pero fundamentalmente es el blues de las tinieblas, el blues de la oscuridad, es el canto al miedo de la oscuridad, a la noche de las mentes, a la Edad Media mental. (registrado em GRINBERG, 2008, p 128)

A fala de Gabis, à vez que identifica a música como "blues de la represión", em um período de tensão muito maior do que quando ela foi gravada, sublinha como “fundamental" uma dimensão autorreflexiva, em um tipo de argumentação semelhante às que mostra Provéndola (2015) nas ocasiões em que os músicos do rock nacional eram questionados sobre sua “definição" política.

Muitos anos depois, em 2007, Gabis toca "Blues del terror azul", cantado na ocasião por Claudia Puyó, em um concerto na Casa de Gobierno Nacional, com a presença do então presidente Néstor Kirchner. Apresenta o blues como "referido al eterno problema de los que nos persiguen de vez en cuando. El blues del miedo."131 No canto, naquela ocasião, há um verso acrescido, precisamente depois do verso que destacamos na nossa análise. "Lo que sienten de este miedo" vai seguido por "que ya no se aguanta más". Cremos que tanto o acréscimo quanto o metadiscurso da apresentação tendem a deslocar a música para uma perspectiva coletiva. O foco continua sendo o medo, mas a distância que implicava a cobrança de sinceridade, algo como "não disfarcem o medo que todos vocês sentem", diminui com a apreciação genérica de que já mais ninguém aguenta. $\mathrm{O}$ verso acrescido passa a ser, ainda, o único que apresenta um sentir não atribuído à $1^{\mathrm{a}}$ pessoa.

${ }^{131}$ Do canal de Claudio Gabis em Youtube, https://www.youtube.com/watch?v=QuoEbWcewUI 


\section{Morirás, Goliat}

Como mencionamos no capítulo anterior, o filme Rock hasta que se ponga el sol, de Aníbal Uset, registra o terceiro recital coletivo da série "Buenos Aires Rock", realizado em 1972. A aparição no filme da banda Pescado Rabioso, segunda que integrou Luis Alberto Spinetta depois da separação de Almedra, é introduzida por um curto sketch filmado em outro lugar ${ }^{132}$.

Por uma rua de um bairro rico caminham os quatro integrantes da banda. Perto deles estaciona um carro grande, com motorista. Do outro lado da rua, para um carro menor e com aspecto descuidado. Dentro dele, um jovem vestido com jaqueta de jeans prepara um rifle. Do carro "rico", quando o motorista abre a porta, desce um homem com uma capa. O jovem sai do carro menor e dispara contra o "burguês", logo no momento em que se cruzam os músicos. A bala vai dar em David Lebón, baixista e um dos cantores do grupo. O músico aparece com sangue e uma tripa saída para fora, dizendo:

¿Qué hacés, loco? ¿Te das cuenta? ¡Pero mirá lo que me hizo este tipo, loco! Pero yo esto no me lo merezco, vení para acá. Si yo fuera otro tipo, ¿sabés lo que te hago? ¿Sabés lo que te hago? En cana. En cana te meto. Taradito.

Lebón pega a tripa que sai do seu ventre e a passa pelo rosto do rapaz do rifle, que fica manchado de sangue. Os outros músicos olham para o jovem armado com gesto desaprovador. Lebón diz “chau, loco”. E Spinetta acrescenta “Tonto". Termina o sketch e, no palco do show, a banda entra para tocar. Spinetta carrega nas costas uma luz de viatura enquanto soa uma sirene policial e o músico repete "uuuhhhh", em tom de vaia, que é continuada por outras pessoas. Alguém diz "la cana, loco". Quando Spinetta tira a lâmpada das costas, começam a tocar o rock "Despiértate, nena", de temática amorosa.

Em um artigo em que discute, no campo da ciência política, relações e diferenças entre a militância os roqueiros, Flachsland (2007, p 24) comenta essa mesma cena considerando que "es una crítica directa a las organizaciones armadas”. Sem dúvida não

${ }^{132132}$ No DVD comercial do filme, publicado pela produtora Aries, a cena está no minuto 53:52. Em Youtube pode ver-se isolada neste endereço: https://www.youtube.com/watch?v=oAvzYKptPu4 
é uma celebração dessas organizações nem da figura do guerrilheiro, mas cremos necessário indagar o modo contraditório como é recortado esse objeto.

Em primeiro lugar, o modo como o músico "ferido", e depois os outros se direcionam verbalmente ao jovem armado é mediante um vocativo, "loco", que funcionava como tratamento de confiança e de identificação grupal entre setores da juventude, em especial os próximos do campo do rock. Quase como "compañero" entre as esquerdas militantes. Dizer “¿Qué hacés, loco?”, por mais que se diga com irritação que não é tanta na fala de Lebón-, é falar com alguém do "mesmo lado". Todo o tratamento verbal e gestual que dão ao rapaz do rifle, que observa atônito e sem reagir, é o que se dispensa a alguém a quem se considera equivocado e que fez algo que se avalia como ruim, mas não a um inimigo ou a alguém cruel. Não há desgarro trágico, as "tripas de fora" são quase um detalhe humorístico. O argumento "esto yo no me lo merezco", dito pelo ferido, abre a possibilidade de outros merecerem, ainda mais levando em conta o valor de contraste argumentativo que o pronome pessoal explícito pode adquirir no funcionamento do espanhol (MARCOS MARÍN, 1978; FANJUL, 2014b).

"Si yo fuera otro tipo..." é o espaço contrafactual em que fica a possibilidade de "meter en cana" o atirador. Mas como o músico é quem é, não vai denunciar, prefere chamar o jovem armado a "dar-se conta", inclusive mostrando as entranhas. "Taradito"133, "tonto" -e não adjetivos relacionados à vileza ou à crueldade- são os qualificativos com que se despedem do combatente, e sem dúvida há a possibilidade de interpretar que essa "estupidez" resida, do ponto de vista do enunciador, no fato de lutar com armas. O próprio grotesco da imagem das entranhas saindo enquanto o músico anda tranquilo e sem dor nenhuma pode sugerir a inutilidade da violência armada, ou inclusive sua inferioridade em relação à "revolução das mentes" que aparece em muitos depoimentos de roqueiros da época, como o que citamos antes de Claudio Gabis em 1974, e que faria dos entendedores seres invulneráveis. O pacifismo era uma constante no rock argentino, mas Pescado Rabioso era um nome de crispação, como a cena filmada e como boa parte do cantar do progressivo argentino na época. A rejeição pela violência armada e até pelo disciplinamento político não apagava a percepção de estar do mesmo lado em relação às sirenes de viaturas.

${ }^{133} \mathrm{O}$ adjetivo "tarado" funciona, nesse caso, como substituível por "idiota" ou mesmo pelo "tonto" que lhe segue. 
Em outra cena, desta vez não cinematográfica, mas musical, do rock argentino desses anos, encontramos uma nova declaração de inutilidade das armas, em uma configuração de perspectivas muito peculiar. A banda Vox Dei gravou, em 1971, o LP conceitual chamado La Biblia, que foi publicado novamente em 1974, com mais sucesso, reunindo uma grande quantidade de músicos do progressivo da época. Essa nova versão, que retirava longos fragmentos instrumentais do primeiro disco, contou inclusive com a participação de uma orquestra sinfônica. O disco de Vox Dei, como também a versão gravada depois pelos outros músicos, apresentava-se como diretamente baseado em determinadas partes da Bíblia judaico-cristã. Díaz (2005, p 105-142), no contexto de uma aprofundado estudo sobre a religiosidade no rock argentino, realiza uma detalhada descrição da articulação das partes da obra em relação com os textos bíblicos, vínculo que é pouco explicitado nos encartes. Para nosso trabalho trataremos apenas de uma das seções do disco, sem intenção de abordá-lo como obra geral. Sobre o deslocamento da tradição religiosa nessa produção, Díaz observa:

La Biblia consiste en una lectura de algunos aspectos del Libro Sagrado, que implica ciertos corrimientos, ciertos cambios de sentido, logrados a partir de una selección realizada entre los muchos textos que lo componen y su ubicación en contextos muy diferentes de los originales. En primer lugar, la música de Vox Dei constituye en sí misma un contexto no habitual para esos textos. Un sonido que desde el principio pone al oyente en contacto con un universo de sentido: el rock duro, el rythm \& blues primitivo, con todo lo que eso implica. Díaz (2005, p 125)

Uma das mais nítidas expressões desse "rock duro" é a seção denominada "Las Guerras". Nela, se reúnem em sequência dois episódios bíblicos que correspondem, nos livros judaico-cristãos, a partes relativamente separadas entre si. Díaz (idem, p 127) explica que o primeiro é o da conquista da Terra Prometida, e o segundo, a luta entre Davi e Golias. Tanto na versão de Vox Dei quanto na do coletivo de músicos dois anos depois, ambas se apresentam em uma continuidade tal que a luta entre Davi e Golias, muito mais reconhecível para o público em geral, parecia a consequência do que se cantava antes.

No primeiro bloco, com um ritmo quase de rock'n roll, os dois cantores da banda, Willie Quiroga e Ricardo Soulé, dão voz conjuntamente a alguém que anuncia vir de longe para ocupar uma terra que lhe pertence e assim cumprir uma promessa. Com veemência anuncia ações contundentes, como derrubar muros e queimar árvores que ele não tenha plantado. O cantar enérgico convida o corpo da escuta a um gesto desafiador, 
à vez que o ritmo dá lugar a uma das poucas passagens musicais do rock argentino dessa época que fizeram parte de repertórios dançáveis, ou que deflagrava situações de dança nos shows ao vivo.

A passagem para o segundo bloco é repentina, e com um ritmo martelado, como acompanhando o andar de um corpo pesado. Uma voz, agora única (Ricardo Soulé no original de Vox Dei, Alejandro Medina na versão coletiva), canta "Desde el campo se escuchó gritar. ¿Quién será capaz de vencerlo al gran Goliath?” A continuidade entre o canto do ocupante da nova terra, que vinha comovendo o corpo da escuta segundos antes, e esse novo relato leva à possibilidade de identificar ambos. Era Golias quem chegava de longe e derrubava muros? Um conhecimento bíblico que poucos tinham os diferenciava, mas para muitos isso podia não ser claro. E precisamente o enfrentamento entre Davi e Golias é, curiosamente, construído, na música, com foco no gigante filisteu, não no jovem herói.

A voz interpela Golias, que é o "tu” durante a música toda. Davi é apenas uma menção, "el gran David”, mesmo epíteto dado a Golias. É o gigante o protagonista do relato, e, na articulação enunciativa mostrada, é o objeto do questionamento da voz no canto. Algumas dessas perguntas se assemelham a increpações que o texto bíblico registra entre Golias e Davi, mas, na canção de Soulé e Quiroga, aparecem todas como palavra do locutor a Golias, e nada há sobre o favor divino que faria Davi triunfar ${ }^{134}$, fator fundamental no relato tradicional. Assim, ouvimos:

¿Cómo estar tan equivocado?

¿Para qué armas en la mano?

Mira, piensa, dime, ¿como estás? ¿Cómo vienes así?

Interrogações todas elas angustiosas, sobretudo na versão cantada por Medina. Nessa performance visceral do mesmo intérprete do "terror azul", o anúncio fatal "Morirás, Goliat" é dito várias vezes, em tom de lamento. E a conclusão posterior à morte do filisteu é repetida e intensificada quase num pranto: “Armas, fuerza, ¿de qué, de qué te sirvió? ¿De qué te sirvieron las armas, la fuerza?"

${ }^{134}$ Consultamos a seção correspondente do "Livro de Samuel" na Bíblia de Jerusalém (2002, p 412-413), edição a cargo de Gorgulho, Storniolo e Anderson, Ed. Paulus, São Paulo. 
Não há sequer ação em Davi, Golias é morto pelo seu próprio erro: "una piedra te hará caer, y tu espada te matará", adverte o locutor-profeta antes de dar passagem à lamentação. Assim, a construção tradicional é invertida na perspectiva, para dar preeminência a uma figura derrotada.

“Las guerras” foi considerada, como aponta Díaz (2005, p 127), uma alegação pacifista. Podemos imaginar que sua prédica contra as armas, em um período em que a viabilidade e/ou a conveniência da luta armada era tópico de discussão para milhares, alguns dos quais já ouviam rock nacional, deve ter irritado a mais de um e somado argumentos para o desprezo pela incurável "falta de ideologia" dos roqueiros. Porém, cremos que, a despeito do desdém dos militantes e do convencimento pacifista do dizer roqueiro, nessa música se materializava uma contradição relativamente indiferente a essas duas percepções. Nas continuidades do corpo violento e gozoso por voltear muros, e nas entranhas do canto pelo grande equivocado, "Las guerras" guardava a consternação e o luto de um sujeito pelo que "se sabia" a perder.

\section{Escada para a terraza}

O poema de Fabián Casas que apresentamos a seguir foi publicado pela primeira vez no seu livro $O d a^{135}$.

\section{Ezeiza}

Mi primo ya no es un gigante

en el crepúsculo de esta terraza

donde estamos sentados.

Dos casas más allá,

con broches en los labios

y pañuelo azul en la cabeza

una mujer cuelga la ropa.

${ }^{135}$ Casas (2003). 
Desde que se fue el libretista

el color whisky del pelo de mi primo

empezó a clarear

y en alguna feria americana

los jóvenes modernos

deben estar probándose

su vieja melena, sus pantalones oxford,

los suecos que yo a veces le robaba

para mirarme en el espejo...

Príncipes violentos de los setenta

¿Qué podemos hacer por ustedes?

No se convirtieron en políticos

ni se exiliaron, ni están

con dos enes en el pecho debajo de la tierra...

Ustedes,

que se colgaron de los árboles de Gaspar Campos

y fueron a esperar al Duce a Ezeiza,

tuvieron que soportar

que el viejo no les trajera la revolución

sino la peste.

"Pero no éramos -dice mi primo-

estetas de la muerte o fanáticos del dolor.

Simplemente buscábamos Tao..."

A la gente le gusta pensar

que la vida cambia. Y muchos viven pendientes

de cosas que no le van a suceder nunca.

Ahí está la vereda cubierta de arroz

del Registro Civil; el libro donde dice:

"Antes vine como el Cordero,

ahora he vuelto como el León". 
Relatos, fábulas para un pueblo construido

de agua y de fe.

La silla de mi primo está vacía.

El viento agita los árboles en la calle.

Es cierto. Todo terminó más rápido

que un día de franco.

Después pasó el tiempo,

viajamos con las tribus del norte hacia el sur.

Algunos se reprodujeron.

Otros aprendimos que el miedo

es la distancia que existe

entre el dolor y la nada.

Yo crecí y me convertí en el líder.

En cuanto al Guerrero del camino,

nunca más lo volví a ver.

Ahora él vive

sólo

en mi memoria.

Pouco depois da publicação do livro, o escritor e crítico literário Martín Kohan deu uma conferência na Universidade de São Paulo, titulada "Dos ausentes en Ezeiza", na qual abordava comparativamente esse poema e outro de Ariel Schettini em torno da configuração da memória histórica e dos saberes na enunciação poética. Tanto o poema de Casas quanto algumas das reflexões de Kohan, registradas depois em uma publicação da USP, vieram à nossa memória durante o trabalho com o material analisado neste capítulo.

Essa lembrança não se deu, no caso, em função das diversas e efetivas vinculações de Fabián Casas com o rock argentino. O poeta e romancista fez letras para músicas da banda Pez, nos 90, em diversas ocasiões escreveu ensaios e matérias de crítica sobre compositores do rock argentino para diversas revistas, e pelo menos um dos seus contos, “Casa con diez pinos", publicado em Los Lemmnings y otros (CASAS, 2011), integra na narração cenas de escuta desse gênero, no caso, da canção homônima de Javier Martínez. 
Mas nada disso se vislumbra em "Ezeiza". O que nos trouxe para esse poema carregado de alusões à Argentina dos primeiros 70 foi o olhar memorioso que se instala nos seus versos, captando com suma precisão um ponto de estranhamento crucial entre percepções e saberes, ilustrativo para o que desenvolvemos neste capítulo e no que segue.

"Ezeiza" dá voz a uma primeira pessoa que evoca um primo alguns anos mais velho, que nos anos setenta parece ter sido um jovem militante. $\mathrm{O}$ título é um eficaz articulador das expectativas frustradas que constituem parte da matéria do poema: ele remete ao acontecimento que sinalizou o começo do fim daquela "aurora del 73", lembrando aqui a imagem de Sergio Pujol que citamos no capítulo anterior, onde também nos referimos ao saldo trágico daquele ato em que era aguardada a chegada de Perón. Nas estrofes $3^{\mathrm{a}}$ e $4^{\mathrm{a}}$ do poema, outras denominações de implantação precisa na memória histórica recente acompanham a daquele fato violento: os exilados; os túmulos de identificação "NN" que começam a ser achados no início de 1983, trazendo à luz a dimensão do genocídio; a rua Gaspar Campos, onde estava a casa que o sindicalismo doou a Perón; as duas denominações para o ex presidente, "el Duce" e "el viejo", cada uma delas evocando perspectivas opostas em torno da sua figura.

A terraza é o ponto de partida do poema e também o início da sua última estrofe. Uma terraza crepuscular, cronografia que Kohan (2007, p 10) relaciona sagazmente com a imagem do primo na perspectiva do "eu" rememorador. Pela nossa parte, cremos que, como todo crepúsculo, o de "esta terraza" supõe um "antes" diurno, como o esplendor do primo que já fora objeto de espelhamento -literalmente, experimentando os sapatos que permitiam aproximar-se da sua altura ${ }^{136}$. Um encontro na terraza não é qualquer lugar da casa nos bairros das classes médias argentinas. Se o divertimento entre primos no quintal, em visitas familiares, tem a ver com os hábitos da infância, "la terraza" é uma passagem para uma sociabilidade adolescente e juvenil. Espaço em altura -uma altura que também permite ver quem chega-, lugar para escutar música e até para fazer festas se o clima o permite, para o contato com o sol e a distância do olhar adulto. A terraza era o espaço por excelência para assaltar os céus quando o primo, quando os muitos "príncipes de los setenta" eram gigantes, e os menores olhavam para eles esperando ser, logo, seus pares.

\footnotetext{
${ }^{136}$ No poema, "suecos" alude a um tipo de sapatos com salto plataforma que eram moda nos 70 .
} 
O ocaso desses "príncipes violentos" é dito com desdém e, como observa Kohan (ibidem, p 10), a partir de construções negativas: pelo que eles não são e pelo que dizem não ter sido. A alusão a que não se contam entre os milhares de desaparecidos ("ni están com dos enes en el pecho debajo de la tierra") leva o desencanto a uma modulação sinistra: se fossem mártires, ao menos saberíamos o que fazer por vocês. A própria autonomia de projeto lhes é negada: sua decadência começou "desde que se fue el libretista", e, na atualidade explicam sua procura com uma definição abertamente contraditória com a da esquerda revolucionária: "buscábamos Tao". O taoísmo, como explica Watt (1999, p 7), é portador de uma visão de mundo que "tiene en muy elevada estima la pasividad, busca siempre adoptar la posición más neutra o inferior y concibe sus estrategias en función del principio de la entrega". Na quinta estrofe, única em que a $1^{\text {a }}$ pessoa se retrai e também o primo e os príncipes não são focalizados, a diferença temporal se apaga e a voz passa para uma consideração geral sobre as crenças e expectativas humanas. Aspirações banais e ingênuas, "fábulas para um pueblo construído de agua y fe", entre as quais parecem cair as mutáveis convicções do primo.

No entanto, cremos que, no poema, não fala unicamente esse desdém cético. O ser posto na $1^{a}$ pessoa é também uma entidade em cena, exposto a uma perspectiva que se distancia das suas modulações mais agressivas, submetendo-o a um olhar avaliativo e disfórico. Não em vão, no início da última estrofe, o "eu” parece admitir reflexivamente algo que lhe fosse questionado: "Es cierto". Abre-se, a partir dali, um rememorar não regido pela rejeição. A constatação "Todo terminó más rápido que un día de franco" estabelece uma percepção compartilhada não apenas de que aquilo que houve foi breve, mas de que foi grato como um descanso, excepcional como uma festa. É nesse ponto, também, que aparece um "nós" não contraposto a outros, com potencialidade de coletivo -quanto menos para o sofrer-, visualizado em êxodos e duras aprendizagens.

Coletivo tribal, bandada aprendendo sobre o medo, como os que emergem nas músicas que observamos neste capítulo. No estudo sobre os roqueiros e a juventude militante como alvo da repressão no início dos 70, que citamos várias vezes no capítulo anterior, Manzano (2014, p 398) conclui com uma metáfora espacial que nos parece extremadamente adequada: "Before the military imposed the most dramatic dictatorship in March of 1976, the youth culture of contestation had begun to back away." Precisamente, uma retirada é o que percebemos como a melhor denominação possível para o que tentamos caracterizar ao longo deste capítulo como essa nova posição de 
sujeito que se instala no rock argentino da época, afetando aspectos da sua regularização. Um saber e pré-construídos que não são os do imperativo de ação transformadora em direção a si, nem os do sujeito do compromisso revolucionário, nem os do ceticismo desconfiado, embora coexista contraditoriamente com todos eles. Esse saber, não desprendido de pré-construídos sobre a necessidade de mudança e de transformação social, focaliza, na sua percepção, a ameaça, o perigo.

Cremos que o "êxodo", com "las tribus del norte hacia el sur", traz, na sua matéria poética, a memória discursiva desse saber da retirada. Enunciar o medo como "distancia entre el dolor y la nada", percorrida, vislumbrada ou apreendida, é dar voz a algo diferente do olhar avaliativo e desdenhoso sobre o primo, "la gente" e o povo ávido de fábulas das estrofes anteriores. E a reaparição final do eu poético, também personagem da história familiar e tribal, traz ainda um novo matiz a esse saber: o "Guerrero del camino". A respeito, fazemos uma leitura diferente da que vemos em Kohan:

\begin{abstract}
¿Cuál es, sin embargo, habría que plantearse, el pasado de esa memoria? No parece que pueda ser el de la melena, los suecos y los pantalones oxford: ese que ahora se consigue en las ferias americanas de los jóvenes modernos. Tampoco el de Ezeiza y el de Gaspar Campos, toda vez que no hubo revolución sino peste, y Perón fue un Mussolini. Más bien parece tratarse de la memoria de un presente, o del pasado más inmediato: no el de los años setenta, sino el este atardecer en una terraza, el del encuentro final de los dos primos: la memoria de una última vez donde nada queda ya, excepto el descreimiento de lo que fue una ilusión política. (KOHAN, 2007, p 12-13)
\end{abstract}

Precisamente porque consideramos essa diferença de perspectiva na última estrofe e esse conflito de subjetividades no poema todo, é que essa figura do "guerreiro" nos parece relacionada a uma lembrança muito mais próxima do ponto de partida, e mais intimamente guardada. Cremos que esse "guerreiro" com maiúscula, que nunca mais foi visto, e somente vive "en mi memoria", habita a distância que era necessário preencher, diante do espelho, com salto plataforma; a que dá acesso para a terraza. A visão de quem está realizando essa passagem na vida já pode conceber para si heroicidades e caminhos abertos, não inseridos ainda no real dos "maiores" que admira. Não um guerrilheiro, um guerreiro. Kohan também aponta essa diferença linguística no seu ensaio, no entanto, nós não a relacionamos apenas ao registro orientalista, mas também, pela sua localização no poema, ao mais caro -e menos adulto- da memória. O guerreiro ficou no dia de franco. E ao saber da ameaça somou-se logo outro: o de que não teria seu principado. 
A geração, ou melhor, a faixa etária de quem em 73 se media nos sapatos do primo, como a de Casas, ficou em uma situação diferente daquela dos seus admirados. Uma relação com os diversos riscos, os da luta política, os de vestir determinadas roupas e ir a recitais, os de compartilhar esquinas e celebrações com amigos, mediada por dois fatores que não tinham se apresentado da mesma maneira para aqueles 5 ou 10 anos mais velhos. Por um lado, mediada pela expectativa em relação ao que seus pares levemente maiores transmitiam das suas atividades, ou ainda por serem parcialmente partícipes -nas terrazas, nas esquinas- dessas práticas mais ou menos próximas. Por outro, mediada pelo medo que vai se instalando em uma grande parte dos adultos da sociedade -e nisso cremos que Carassai, que referimos no capítulo anterior, acerta-, não entusiasmados pela adrenalina dos enfrentamentos nem pelas tentativas de renovação das formas de vida. Esses novos adolescentes chegam já com a percepção que de provavelmente as vivências não sejam iguais para eles. Na latência de um toque de recolher, vivem um duelo pelo que não farão.

Alguns começam a ouvir e a ter entre seus gostos a "música progressiva", logo no período em que esta deixava de ser uma experiência de vanguarda e ampliava paulatinamente seu território de alcance. As bandas e solistas dos quais tratamos neste capítulo, e outros que iam aparecendo sob a marca da consternação fizeram parte da escuta desses recém-chegados. Porém, uma banda em especial lhes pertenceu como nenhuma. Sui Generis, dupla que começa a gravar em 1972, foi a primeira formação do rock argentino que atraiu primeiramente adolescentes, para depois chegar ao resto do público jovem do campo. Foi, também, a primeira que atingiu, nos seus três anos de vida, algo timidamente próximo da massividade, embora incomparável com o que viria nos 80 . Concomitantemente com essa implantação específica no campo do rock, a atuação da dupla de Charly García e Nito Mestre ${ }^{137}$ coincidiu cronologicamente com o último período do imperativo de "definição política" que, como explicamos no capítulo anterior, trouxe pessoas mais jovens e em maior quantidade aos movimentos estudantis. E coincidiu também com o terror crescente das ações paramilitares, ameaças e atentados que precederam o golpe de 1976.

\footnotetext{
${ }^{137}$ Depois da separação de Sui Generis, acontecida em 1975, ambos fariam carreira em outras bandas e como solistas, em períodos que não correspondem aos que estudamos nesta tese. Charly García se consolidou nas décadas de 80 e 90 como a figura pública mais conhecida do campo do rock no país, único que fez parte, embora com uma imagem exótica, dos famosos da grande mídia.
} 
Nos seus três anos de existência, Sui Generis produziu, de modo geral, uma música menos "crispada" que as que vimos neste capítulo, ao ponto de ser considerada por alguns como uma variante musicalmente "branda" do rock argentino. Porém, como bem aponta Schanton $(2013, \mathrm{~s} / \mathrm{n})$ "El dúo transmitía ese sabor agridulce de aquellos años violentos, en los que parecía que no se podía hablar de vida sin hablar de muerte". Do nosso ponto de vista, nas suas músicas, a generalização do terror que se operava no espaço público, as ausências e a percepção de catástrofe ganharam uma forma peculiar, que podemos antecipar como uma certeza da privação e da falta. Não em vão seu principal corpo de escuta esteve entre aqueles para quem a década das grandes batalhas chegou a ser apenas a percepção de um breve día franco, em um espelho em que não chegaram a se ver completos. Sobre isso trata nosso próximo capítulo, o último desta tese. 


\title{
Capítulo X
}

\section{Escondeme en tu memoria}

\author{
(Terceiro caso)
}

Hemos intentado hacernos perdonar lo que no hicimos, las ofensas fantásticas, las culpas fantasmas. Por bruma, por nadie, por sombras, hemos expiado.

Alejandra Pizarnik ${ }^{138}$

O recital com que a dupla Sui Generis se despediu do público ao decidir sua separação foi o maior que uma banda sozinha tivesse feito até então no rock argentino. Naquele 5 de setembro de 1975, os dois shows consecutivos no estádio Luna Park totalizaram em torno de 30.000 espectadores (BERTI, 2000, p 62). O evento ficou conhecido como Adiós Sui Generis, e além de um LP duplo, rendeu um longa-metragem documental, dirigido por Bebe Kamin.

Assistir o longa permite ver, já nas tomadas iniciais feitas enquanto o público entra no Luna Park, o predomínio dos muito jovens. Vê-se, inclusive, alguns poucos acompanhados por pais ou avós. Segundo Berti (ibidem), a média de idade era de 14 ou 15 anos, e o fato de o show acontecer nesse espaço tradicional favoreceu que a muitos menores fosse permitido comparecer, o que não teria sido tão fácil sendo em um clube ou em teatros. O filme só foi estreia no ano seguinte, já sob o governo militar, e qualificado com censura 18 anos, o qual lhe restou boa parte do potencial público. E outra boa parte deve ter desistido pelas blitzen policiais nas proximidades do cinema. Porém, agora, décadas depois, ao assistir o DVD, contemplamos a multidão expectante, ocupando seus espaços no estádio coberto. E, logo nos créditos, sabemos que estamos vendo através da lente de um desaparecido. As câmeras estiveram a cargo de Raimundo Gleyzer, documentarista militante que mencionamos no Capítulo VIII, sequestrado pela ditadura em 26/5/76, antes de que o filme chegasse aos cinemas. Enquadrando com a habilidade de quem sempre buscou hipóteses nas multidões, Gleiyzer capta de perto a entrada

${ }^{138}$ De "Nombres y figuras”, em Antologia Poética, Buenos Aires, Cántaro, 1997. 
entusiasmada e apressada de meninos e meninas que parecem vir direto do colégio, a procura pelo melhor assento, a expressão resignada dos adultos que têm pela frente duas horas sentados nessa espécie de recreio gigante, a presença de policiais uniformados de azul.

González (2000) conta que horas antes de o show começar, chegou aos músicos e técnicos a notícia de que em La Plata, na madrugada desse mesmo dia, um comando paramilitar tinha sequestrado e assassinado um grupo de jovens militantes de esquerda. Era o primeiro episódio do "Massacre de La Plata", um dos que relacionamos no Capítulo VIII, e que no dia seguinte continuaria com mais três vítimas dentre os que saíram a repartir panfletos denunciando os assassinatos. Os mortos do dia 5 eram conhecidos do baterista da primeira formação do grupo, que tinha sido convidado para a sessão de despedida da banda, daí que o aviso chegasse logo nesse momento. Pensou-se na possibilidade de que os músicos pedissem um minuto de silêncio durante o show, mas isso não aconteceu. $\mathrm{O}$ cronista lembra, 25 anos depois, que "fue como uma explosión de tristeza en medio de la euforia que caracteriza lo que hoy se llama backstage" (ibidem, p $63)$.

A câmera do desaparecido e o backstage do silêncio são pontos invisíveis que observaram a cena toda. Evidenciam que para aproximar-se de Adiós Sui Generis não há como se contornar o terror, embora efetivamente estejamos assistindo um recital pleno de vitalidade. Ele aconteceu sitiado por essas ausências ou iminências de perdas, como tantas práticas culturais naqueles anos. Neste capítulo percorreremos algo da música que convocava esses milhares e outros tantos que não foram ao estádio. Nela, o "adiós" não foi só naquele dia. Do início, a perda e a privação foram se abrindo caminho mesmo entre as mais cálidas notas. Nas palavras de Gonzalo Aguilar (1998, p 28), rememorando ter sido parte dos ouvintes de Sui Generis, "Los sueños terminaban, pero las pesadillas las habían tenido quienes no habían soñado nunca".

\section{1. ¿Dale que nos morimos?}

O primeiro LP de Sui Generis, Vida, foi publicado em 1972 pela Talent que, como explicamos em capítulos anteriores, foi uma continuidade de Mandioca, a gravadora dirigida por Jorge Álvarez. Isso significava, em termos do mercado de bens simbólicos, 
um início no coração mesmo do que já estava delimitado como "progressivo" e, portanto, nas margens da grande indústria. No entanto, o LP surpreendeu vendendo 80.000 cópias (Conde, 2007, p 230), cifra que podia ser irrisória se comparada com o meio milhão com que era lançado um disco de baladistas famosos ou de sucessos de danceteria, mas com poucos antecedentes em LPs do rock local ${ }^{139}$. Predominava no disco um estilo de folk (idem, p 228), relativamente infrequente no progressivo da época, que alguns apontam como fator importante no seu sucesso entre adolescentes. Outro aspecto relacionado a esse sucesso entre os mais jovens, e que nos parece fundamental, é o que aponta Alabarces (1993) notando que García compunha nos gêneros mais propícios ao canto coletivo entre não profissionais:

Sui tendrá una importancia crucial en una práctica que se transforma, pero no se pierde: la guitarreada entre amigos. Que no la inventa el rock, la inventa el boom del folklore a comienzos de los sesenta, y se continua en el folklore politizado de finales de la década. (ALABARCES, 1993, p 66)

Cremos que a observação do sociólogo é importante, no contexto do nosso trabalho, em relação a algo que explicamos a partir do Capítulo VIII: uma maior confluência, nas novas juventudes urbanas dos 70, de aficionados à música rock com simpatizantes de esquerda. A "guitarreada" foi sem dúvida um tipo de prática que operou nesses espaços de encontro e que foi favorecendo uma interseção dos corpos de escuta.

No início do Capítulo III mencionamos uma situação em 2009, em um curso na Universidad de Buenos Aires, quando tentávamos lembrar de composições do rock nacional que contivessem narrativas de mortes individuais, e que a primeira que veio à memória foi "Mariel y el capitán”, precisamente desse primeiro disco de Sui Generis. Explicamos também que houve concordância em que "não contava" por tratar-se de uma evidente chacota, uma peça humorística. Com efeito, os próprios efeitos sonoros dessa canção a aproximavam ao universo do teatro infantil como brincadeira tardia ${ }^{140}$. Mas também em Vida havia “Canción para mi muerte”, primeiro grande sucesso da banda, que

\footnotetext{
${ }^{139}$ Compactos que surpreenderam, como "La balsa", de Los Gatos, chegaram a 200.000 cópias. Os LPs não superavam ainda os 50.000, como o primeiro de Almendra que analisamos no Capítulo V.

${ }^{140}$ Não casualmente Luis Alberto Spinetta empregou a qualificação "una onda María Elena Walsh" (Berti, 2000, p 64) a 'primeira vez que ouviu Sui Generis, dupla que depois admiraria. María Elena Walsh foi uma prolífica compositora argentina da segunda metade do século XX que, dentre outros gêneros, produziu canção infantil.
} 
personificava a morte como alguém a quem se esperava de modo desafiante. Quando uma canção tem um refrão nítido, como foi o caso dessa, o refrão tende a ser o que mais se guarda, o que mais circula, porque atravessa mais facilmente a tensão letra / música que tratamos no Capítulo I com base em Frith ([1998] 2014). O refrão de "Canción para mi muerte" permitia a um adolescente da época escutar e cantar um tipo de convite sexual que jamais ouviria na música "nuevaolera", e que mesmo no rock nacional era raro ${ }^{141}$ :

Te encontraré una mañana

dentro de mi habitación

y prepararás la cama para dos.

Não conhecendo o título, podia ouvir-se a música toda sem pensar na morte, e mesmo conhecendo-o, "la cama para dos" despertava sem dúvida maior curiosidade. Várias outras músicas do disco ("Estación", "Quizás porque”) descreviam situações amorosas com clara referência à vida sexual. Porém, já havia em Vida alguns tons melancólicos, e uma das canções, "Amigo mío, vuelve a casa pronto", mostrava traços do que no capítulo anterior chamamos "consternação": receio da perda, o retorno à casa como refúgio.

\section{Escarbo hasta abrazarte}

O segundo LP se chamou Confesiones de invierno. Para os fãs, simplesmente “Confesiones", e foi lançado em 1973. O encarte, sobre um fundo amarelo pálido, mostrava fotos da dupla, músicos e amigos em espaços naturais realçados com filtro de tal modo que semelhavam os pósters típicos de quarto juvenil da época. Beleza e luz, mas, como em muitos pósters, também algo de escuridão para o brilho. E começar a escutar o disco era encontrar-se com um som taciturno. O piano se ouve quase fúnebre, dando vez à voz de Cahrly García em um cantar lento: "Tendré los ojos muy lejos / y un cigarrillo en la boca / el pecho dentro de un hueco / y una gata medio loca".

${ }^{141}$ Até então, somente duas músicas continham um chamado tão direto: "Me gusta ese tajo", de Pescado Rabioso, e "Tren de la hora 16", de Pappo's Blues, ambas rock pesados. 
Era assim o início da canção "Cuando ya me empiece a quedar solo", primeira que se ouvia no LP e uma das mais melancólicas na carreira de García ${ }^{142}$. Depois, a música que dá nome ao LP, "Confesiones de invierno", tem a construção sequencial de uma crônica cantada, mas, do nosso ponto de vista, resiste as leituras de procura de verossimilhança que costumam se fazer em torno dela. Parece mais uma fantasia de desamparo total, em tom hiperbólico. Cada uma das situações passadas pelo personagem no qual o locutor se desdobra na narração guarda verossimilhança; ser expulso pela parceira, perambular sem abrigo, apanhar da polícia, internar-se. O peculiar é a confluência de todas elas e sua hierarquização como "consequências" do abandono amoroso. "Confesiones de invierno", como algumas outras músicas do primeiro período de Sui Generis, se aproxima de fronteiras melodramáticas do tipo das que indagamos no Capítulo III como pouco frequentadas pelo campo do rock argentino da época, embora se afaste do melodrama pela perspectiva contestatária e a não celebração da virtude. Para o que estamos tratando aqui, é interessante observar que a narração é um percurso entre dois quartos: "me echó de su cuarto" / "mi cuarto da al jardín”. A saída do primeiro, expulso, é o total desamparo. A rua não é a topografia do personagem, como em músicas do primeiro rock argentino. Não se trata de um "náufrago" procurando "el lugar que yo más quiera". Ele até diz não saber partir. O espaço da rua chega a ser metaforizado como inferno, com portas que podem enclaustrar, e do qual é necessário escapar. No percurso, a rua está no mesmo plano que a "cárcel" onde o personagem é levado por ebriedade. O quarto de chegada, embora remita a um hospício, é refúgio.

E a música desse disco que mais chama nossa atenção em função dos modos de representar a privação que observaremos neste capítulo é a que, junto com "Canción para mi muerte" provavelmente seja a mais lembrada da dupla: "Rasguña las piedras". Como registram Manzano e Pasqualini (2000, p 78), “uno de los temas más escuchados del LP”. Há muito de estranho e surpreendente em relação a "Rasguña las piedras". Musicalmente não era algo tão elaborado, considerando a época; para 1973 o rock argentino já tinha produzido composições bem mais complexas. Porém, não pode se dizer que fosse uma música facilmente "cantável” em "guitarreadas", já que continha várias mudanças de ritmo e de melodia. Mas era quase obrigada em reuniões de amigos com canto. Alabarces

\footnotetext{
${ }^{142}$ Em um ensaio que publicamos há poucos anos (FANJUL, 2014a), realizamos uma extensa análise comparativa entre essa música e outra muito posterior do rock argentino ("Sobre madera rosa", de Gabo Ferro, gravada em 2005), em torno da enunciação biográfica. Neste trabalho, em função do foco escolhido, não nos estenderemos sobre essa canção.
} 
(1993, p 68), por exemplo, menciona essa canção como protótipo desse tipo de prática, e era também uma das mais pedidas e cantadas a coro nos recitais ${ }^{143}$. Um fascínio nada ordinário e digno de indagar, diante de algo que combina momentos de um cantar delicado com um rock em alta voz e, sobretudo, imagens verbais gozosas com outras verdadeiramente sórdidas.

"Rasguña las piedras" é também um problema para os enfoques conteudistas e/ou alegóricos que predominam nos estudos sobre o rock. A letra está organizada como uma sequência narrativa relativamente nítida: alguém se esforça para encontrar-se com o ser amado tendo que vencer, para tanto, um impedimento que o obstaculiza, e finalmente consegue seu propósito. Porém, tudo que tem a ver com o espaço representado e com o contato físico entre os seres é confuso e perturbador. A inquietação que essa música provoca se percebe inclusive na argumentação polêmica que desenvolvem algumas leituras críticas:

A pesar de la leyenda, esta canción no habla de ninguna muerte, y su verso más transcendente - la pista más firme para un análisis- es "pero qué libres vamos a crecer". (CONDE, 2007, p 235)

Que pareça tão imperioso estabilizar "de qué habla" a canção e rejeitar "lendas" é coerente, por uma parte, com uma concepção do sentido como algo a ser capturado por "pistas", que não é, evidentemente, a que aqui nos move. E cremos que a necessidade de rebater expressa, por outra parte, o perturbador que há na mistura de imagens da composição. Também a procura de alegorias contextuais cronológicas fecha a canção sob conceitualizações que não harmonizam com a sua matéria significante. Manzano e Pasqualini (idem, p 78), tentando estabelecer uma relação com o "clima de confianza y consenso generalizado" que teria sucedido ao retorno do peronismo ao governo nesse ano, afirmam que essa canção arranca de "uma situación originaria de incomunicación y aislamiento". Como pode deduzir-se deste capítulo e dos anteriores, não concordamos com que essa visão esperançosa da conjuntura de 73 tenha sido generalizada, menos ainda no campo do rock. Mas não é isso o que mais nos distancia da leitura alegórica. Cremos que a observação da materialidade sonora e verbal nessa música não se deixa fechar sob

\footnotetext{
${ }^{143}$ Isso é muito nítido, por exemplo, no filme Adiós Sui Generis. É a música de encerramento do recital, antes dos bises. Também o recital coletivo de 11/11/1977, no estádio Luna Park, dois anos depois da separação da dupla, quando Charly García reuniu músicos com que tinha tocado em diversas formações, foi encerrado com "Rasguña las piedras".
} 
uma figuração estabilizada. Pelo contrário, mostra uma co-ocorrência de muito do que cada um desses críticos observa: há essa "frase" que Conde resgata, como há, também, imagens que remetem a um morrer de amor ou amar vencendo a morte. Há isolamento, sordidez e também libertação, e ainda, como bem observa Colomba (2010, p 195) em um comentário breve, sexualidade.

No início da música, as quatro primeiras notas do piano soam como sinos. García começa a cantar com voz calma "Detrás de las paredes / que ayer te han levantado / te ruego que respires todavia." Ouve-se um efeito sonoro de respiração. Esse efeito, por uma parte, acrescenta sensualidade, e por outra, se vincula, na letra cantada, a um limiar entre a vida e a morte: "apoyo mis espaldas / espero que me abraces / atravesando el muro de mis días". O imediato pedido de arranhar as pedras, refrão da canção, configura de uma maneira peculiar a cenografia da qual se canta o desejo de encontro. Imagens como a de escarvar até as mãos sangrarem são congruentes com essa figuração que, por mais discordante que possa resultar em relação ao tom passional e ao "final feliz" para os amantes, estão ali e evocam um universo de objetos relacionado ao fato de morrer.

O momento de "encontro" desloca essa atmosfera para a materialidade musical mediante um efeito sonoro: na metade da música, quando novamente as vozes e o piano ficam sozinhos, a prolongação do canto sobre a sílaba final em "despertarteeeee...." se mantém como um eco, e é sobre esse eco que se retoma o cantar. Os versos que seguem fazem confluir uma nova imagem relacionável ao sepulcral com outra fortemente sensual: "Y por fin veo tus ojos / que lloran desde el fondo / y empiezo a amarte com toda mi piel".

Com essas observações não queremos dizer que "Rasguña las piedras" tenha "inspiração" em algum caso de prisão ou sequestro dos muitos que aconteciam na Argentina da época, sequer visualizamos nela qualquer direcionamento para uma encenação da luta política. Consideramos, portanto, uma saturação artificiosa a que se fez incluindo essa música no filme La noche de los lápices, de Héctor Olivera ${ }^{144}$, em cenas de comunicação entre adolescentes presos em um campo de detenção clandestino. Mas

\footnotetext{
${ }^{144}$ O filme, realizado em 1986, é uma ficção com propósito testemunhal sobre o operativo de terrorismo de Estado conhecido como "Noche de los lápices". Em setembro de 1976, já com Videla na presidência, comandos militares à paisana sequestram das suas casas na cidade de La Plata dez adolescentes que tinham participado, como secundaristas, de mobilizações pelo bilhete estudantil um ano antes. Duas das moças estavam grávidas. Todos foram recluídos em vários centros de detenção clandestina, onde foram torturados e estuprados. Três deles sobreviveram, todos os outros continuam desaparecidos. Não se sabe se as que estavam grávidas chegaram a dar à luz.
} 
cremos que essa "forçação de barra" não deixa de apoiar-se em elementos da letra, embora afastados completamente das suas relações enunciativas. Também não pensamos que trate de "uma morte" no plano dos afetos íntimos. Há nessa canção uma abordagem do amor e da paixão em uma topografia de encerro que, por momentos, evoca o sepulcral e fantasias mortuórias. O que destacamos, então, é que essa topografia se entrelaça com as imagens de um reencontro gozoso.

A ausência e a privação impregnam o prazenteiro, o plácido, que requer, para realizar-se, de uma força que permita escapar. Se de impedimentos sociais para o amor se trata, como lemos em várias interpretações da música, cremos que não é a mesma coisa o conhecido tópico do "muro que se interpõe entre nós e nosso amor derrubará" que algio como "detrás de las paredes que ayer te han levantado te ruego que respires todavía" e as outras imagens sórdidas ou cruentas que povoam essa canção. E, sobretudo, encontramos muito significativo que uma peça assim tenha sido tão abundantemente escutada por pessoas verdadeiramente muito jovens e cantada em encontros e "guitarreadas", que são, também, situações de confluência emocional e de sedução. Algo havia, "no ar" da discursividade, que ganhou corpo e voz nessa música, na sua escuta e na sua reprodução.

Lemos em críticos e comentaristas que a lobreguidão seria uma característica recorrente na primeira época de Charly García (FAVORETTO, 2014, p 40-41). Embora nosso foco não sejam os estilos singulares, não negamos que isso possa ser assim. Porém, isso não explica a acolhida dessa canção específica. E, se García frequentava o lôbrego, a observação do campo na época mostra que ele foi acompanhado por muitos. A dupla Pastoral, por exemplo, formada em 1974 em um estilo folk muito semelhante a Sui Generis, teve como maior sucesso a música "En el hospício", com climas de angústia e encerro semelhantes aos que apareciam em algumas canções de Charly. O próprio Nito Mestre, companheiro de García em Sui Generis, depois da separação da dupla, se dedica a uma música predominantemente acústica. Em várias das suas canções, como "Mientras no tenga miedo de hablar" combina o âmbito emocional intimista com imagens de refúgio e de percepção de ameaça. Finalmente, em várias das músicas que abordamos no capítulo anterior, a maior parte de elas de compositores já em plena atuação quando da aparição de Sui Generis, a lobreguidão invade diversos tipos de cenografia. 


\section{Ausência e refúgios}

Algumas músicas que Charly García compôs na época de Sui Generis foram gravadas depois da separação, ou inclusive com outras bandas. "Eiti leda", por exemplo, apareceu no primeiro disco de Seru Giran, terceira formação integrada pelo músico, em 1978. Mas já é executada em 1975 no recital Adiós Sui Generis, como o registra o filme que mencionamos na introdução deste capítulo, em cujos créditos aparece com o nome "Nena"145.

"Eiti leda" está construído como uma sequência de interpelações de um locutor em $1^{a}$ pessoa a uma mulher denominada pelo vocativo "nena". Três das quatro estrofes seguem uma melodia semelhante entre si, próxima de uma balada leve. Encabeçadas todas pela forma "Quiero...", as longas estrofes formulam pretensões mínimas sobre cenários de desolação, com abundância de imagens de escuridão e frio. A canção é legível na dimensão intima, mas o tétrico do espaço representado se impõe invadindo o próprio corpo, sua vitalidade e sensualidade. Tanto imagens verbais referidas ao corpo -o coração que pode apodrecer, os ossos frios- quanto o próprio corpo da voz no canto são trêmulos e acanhados. A partir da segunda estrofe resulta difícil localizar o taciturno apenas nas peripécias de um ser singular, como em "Confesiones de invierno". É esperado um dia com uma nova paisagem, em que desfilem "los cuerpos que han sido salvados", o inverno foi ruim, há navios ancorados em um mar congelado. Kozak (2000) inclui esta música entre aquelas nas quais encontra um "desenho de significação" que denomina como "sobrevivente". Figuras que "sólo se nombran a sí mismas: cuerpos presentes, establecen una relación elíptica con los cuerpos ausentes". A autora considera "Eiti leda" anacronicamente como produzida nos últimos anos da ditadura, equívoco frequente devido a que a primeira gravação está apenas em um filme pouco conhecido, e com outro nome. Porém, cremos que a noção de sobrevivência se adequa, porque vemos, na soturnidade dessa música, um perceber-se sobrevivente, precisamente pelo seu

\footnotetext{
145 Pensamos que a mudança no nome da música para "Eiti leda", palavras que não se encontram em nenhuma língua, pode ser contextualizada no que foi o primeiro disco daquela banda em 1978. O nome "Seru Giran" e a letra da música que levou esse título era definida pelos músicos como de um "idioma inventado" (LERNOUD, 1978, p 27). Publicado em plena ditadura, Díaz (2005, p 162) relaciona essa opção do disco em relação ao linguístico com "una situación política en que la palavra disidente está excluída". A única mudança da letra entre as gravações de 1975 e 1978 é coerente com esse tratamento do linguístico: "infinitos carteles que nos den las gracias" cambia para "infinitos carteles que no digan nada".
} 
atravessamento por uma posição de sujeito cujo saber de duelo, como explicamos no capítulo anterior, vai formando as condições de enunciabilidade das ausências.

Um lado mais diáfano da "retirada" e da certeza de privação se vê nas canções que de diferentes maneiras se situam em cenografias de refúgio, como "Pascual tal cual", de Edelmiro Molinari, que analisamos no Capítulo VI, as de Nito Mestre que mencionamos no item anterior, ou "La colina de la vida", de León Gieco. De modo geral, compositores da vertente mais acústica do "progressivo" da época. Cremos que a música "Quiero ver, quiero ser, quiero entrar”, composta por Charly García aproximadamente em 1973, é um dos exemplos mais nítidos dessa combinação de calidez com melancolia. A gravação se fez só em 1976, no disco coletivo PorSuiGieco, que reuniu vários músicos de tendência acústica: os recém separados Sui Generis, Raul Porchetto, León Gieco e María Rosa Yorio, voz líder nessa canção.

A música se inicia com uma introdução com guitarra elétrica e piano, e termina com uma entrada de vários instrumentos, bateria inclusive, e vozes em coro. Entre esses início e final, toda a música é piano e voz feminina, por momentos replicada por algumas vozes masculinas. Ao longo da música toda, a voz se direciona a uma segunda pessoa, sobre a qual não há denominações nem vocativos, que, de início, é anunciada como ausente. Nas várias imagens que a voz vai tecendo, o ser evocado, apesar da sua ausência, aparece como um vector de todo deslocamento e percurso vital. Há uma clara assimetria em relação ao locutor que o evoca e a ele se direciona; o "eu" locutor assume um lugar de descoberta e aprendizagem, que pode ser possibilitada pelo outro. Embora a voz se mantenha no registro de uma mulher jovem, o dizer passa, em alguns pontos, por formulações relacionáveis ao universo infantil que reforçam essa assimetria, como "presentame al señor tiempo", "remontame en um barrilete" o "contame um cuento de hadas".

Cada uma das três partes começa com uma demanda da qual o "eu" seria beneficiário: "presentame”, “invitame”, "remontame”. Na primeira parte, algumas pinceladas sobre o percurso de vida instalam o tipo de temporalidade resultativoavaliativa que dominará a retrospecção na canção toda: "quién ha ocupado mis días" "qué ha pasado por mis manos" ${ }^{146}$. Na apreciação do acontecer, parece haver algo que

\footnotetext{
${ }^{146}$ Nos espaços de língua espanhola nos quais o "Pretérito Perfecto Simple" é a forma preferida na narração e para os valores perfectivos aorísticos, como é o caso da região de Buenos Aires (García Negroni, 1999), o "Pretérito Perfecto Compuesto" ganha diversos matizes aspectuais conforme as relações intradiscursivas
} 
se reconhece como vivido ou sentido menos que o esperado. Assim, na segunda parte, a história e o percurso do outro podem ser um modo de viver o que não se viveu. A palavra dessa pessoa, bem como o saber sobre ele poderiam operar um deslocamento necessário para aquele que se enuncia como "eu". A canção não tem a sordidez das paisagens desoladoras de "Eiti leda", mas, na sua calidez, também está feita de ausência. O tempo morreu em abril e há desejo de chorar.

Não há desespero no canto, o ausente pode produzir melancolia, mas remedia o que não se andou, nem se viveu, nem se tocou. A grande aspiração continua sendo o deslocamento, a descoberta: "ver”, “ser”, “entrar”, “andar”, "penetrar”, “estar” são precisamente os desejos cantados por diversas vozes da banda ou em coro, e não pela voz líder, na interpretação. Porém, não se trata da mudança crítica mediante o desprendimento total, que vemos na primeira regularização, do náufrago que se apropria do espaço e do tempo. Na canção que nos ocupa, esse antigo percurso de ruptura parece mais relacionável ao "tu", àquele com quem o "senhor tempo" se foi, àquele cuja história tem a capacidade de transformar e fazer andar. "Esconder-se na memória" desse ser garante as pretensões do refúgio, que, como em "Eiti leda", são mínimas. Uma promessa de placidez diante do que já não haverá.

\section{O humano entre túmulos}

O terceiro e último LP de Sui Generis, gravado na segunda metade de 1974, acabou recebendo o nome de Pequeñas anécdotas sobre las instituiciones. O nome originalmente pensado, Instituciones, ficou só para a primeira faixa. A mudança foi parte de um intenso processo de censura preventiva ${ }^{147}$, talvez o maior da história do rock argentino. Conforme explicamos no Capítulo VIII, a extrema-direita já concentrava o poder no governo peronista, a censura direta ou as ameaças "informais" eram cotidianas sobre os espaços de espetáculo. O produtor Jorge Álvarez advertiu que havia pressões

e/ou argumentativas em que ocorre. Na letra dessa música há uma variedade desses matizes: iterativo como pluralidade de eventos nas duas formulações que acabamos de apontar na primeira parte, de pertinência vigente como em "has llegado" na segunda parte, ou experiencial (DI TULIO e MALCOURI, 2012, p 273) como em "si alguna vez te he mirado", na parte final. Em todos os casos, esses valores aspectuais estendem a perspectiva do locutor -e, com ele, a da interlocução- sobre o processo e seu resultado presente.

${ }^{147}$ Preferimos essa denominação a "auto-censura", que concentra a responsabilidade no próprio produtor, e parece extremadamente inadequada para contextos políticos como o que estamos abordando. 
para que não se gravassem determinadas canções que já eram conhecidas pelos shows em clubes e teatros, ou que fossem mudadas as letras (CONDE, 2007, p 236-237). Duas músicas que já estavam gravadas foram eliminadas do projeto: "Botas locas”, sátira sobre a conscrição no exército, e "Juan Represión”. A letra de uma canção chamada "Música de fondo para una fiesta animada", que narrava uma orgia na casa de um juiz, foi completamente modificada, e outras três sofreram importantes alterações, realizadas às pressas no estúdio de gravação. As duas eliminadas foram resgatadas vinte anos depois e incluídas em uma edição em CD. Das que foram modificadas se conhecem os originais por gravações de shows ao vivo, com deficiências de sonido, como a da música "Instituciones" que disponibilizamos no Apêndice. A reconstrução das letras por jornalistas especializados como Fernández Bitar ([1987] 2006), que foi próximo da banda e dos produtores, contribuiu para que se conhecessem mais tarde.

O disco introduzia a passagem de Charly García para um rock menos acústico e influenciado pelo "sinfônico" de bandas inglesas como Genesis ou Yes: "empieza a experimentar con los sintetizadores y electrifica el sonido, dándole una base compacta de bajo y batería que no había en los primeros discos" (DÍAZ, 2005, p 154). Isso não impediu vários retornos do compositor ao acústico e ao folk (o próprio disco continha duas faixas completas, e variações dentro de outras, que apontavam para esse estilo), mas contrastava claramente com os dois discos anteriores da dupla. Não menos importante, mesmo com toda a censura praticada, o LP ficou como um trabalho conceitual fortemente contestatário. Fazendo jus ao nome, diferentes aspectos do funcionamento institucional eram objeto de questionamento e sarcasmo. Não chegava a ser o que, no tempo, era conhecido na Argentina como "música de protesta", mas era um material revulsivo em relação às representações conservadoras da família, do casamento, da censura estatal, das forças armadas, da justiça e do poder público, instituições questionadas com agressividade nas músicas. A canção que tratava sobre o censor oficial, por exemplo, incluía uma sequência com efeitos sonoros em que o censor se excita com uma cena do filme que está avaliando e fantasia que corta a mulher com as suas tesouras de trabalho.

Uma das músicas que não sofreu nenhuma modificação para ser gravada foi "El show de los muertos". Provavelmente não tenha sido alterada porque não aludia visivelmente a nenhuma instituição, tradição ou interesse que se pudesse perceber como ofendido. A escuta dessa música em retrospectiva surpreende, ao ponto de haver opiniões de que ela "preanunciaba sin querer el horror de los desaparecidos, los centenares de 
tumbas NN, los centros de detención clandestinos" (CONDE, 2007, p 238). Pela nossa parte, por mais interessante que possa nos parecer a ideia de "pré-anúncio" como metáfora recorrente na observação posterior de catástrofes sociais, preferimos não adotá-la. Por um lado, porque cremos que a atmosfera de terror que se instalava no pais impregnava essa música, mas de modo difuso, como tantas outras que abordamos nos dois últimos capítulos. Em meados de 1974, o horror não requeria premonições: já estava presente. Não havia ainda desaparecidos nem centros clandestinos de detenção, mas sim dezenas de assassinatos amplamente divulgados, um terrorismo de Estado abertamente atuante e uma perspectiva de agravamento da violência armada ostentada por todos os envolvidos ${ }^{148}$. Por outro lado, porque não percebemos "El show de los muertos" como testemunho, mas como um vigoroso exercício de dúvida. No quadro de filliações discursivas que abordamos nesta tese, vemos essa música como um particular terreno de embate entre perspectivas em torno da responsabilidade do indivíduo em relação ao coletivo. Em todo caso, que esse questionamento da responsabilidade, fortemente marcado pelo tipo de humanismo que localizamos no campo cultural da época, seja posto em cena em relação ao morrer, ao matar e aos mortos é o que lhe dá um vínculo não transparente com a consternação já instalada no discurso do rock argentino.

O termo "show" no título da música não é casual: trata-se de mais um caso, no progressivo, em que se lança mão nitidamente de elementos de teatralidade ${ }^{149}$, inclusive com "aplausos" de um público imaginário no final. Em particular, um modo de cantar e de interpelar o público que remete ao humor ácido do café-concert. A forma musical lembra esse gênero e o teatro de revistas. Zariello (2008, s/n) a caracteriza como "primera incursión de García en ritmos de jazz mientras canta tranquilamente -con la tranquilidad de los cínicos- sobre un clima opresivo y fúnebre”. Pode ser que seja adequada a vinculação com o campo do jazz, mas certamente nas suas realizações mais próximas do cabaré e do music hall.

\footnotetext{
${ }^{148}$ Algumas das maiores ações da Triple A que referimos no Capítulo VIII a partir de Mereles (2016) e Novaro e Palermo (2011) já tinham acontecido quando da gravação do LP, mostrando inclusive de modo descarado sua relação com o aparelho de Estado. Em 31 de julho de 1974, por exemplo, foi assassinado o deputado peronista de esquerda Rodolfo Ortega Peña. A Polícia Federal, cujo comandante, Villar, era ligado à Triple $\mathrm{A}$, prendeu todos que foram ao enterro, inclusive com perseguição entre os túmulos. Dias depois, a Triple A panfletou uma lista de todos que tinham sido levados na delegacia, ameaçando-os de morte e ostentando assim sua vinculação com a polícia.

${ }^{149}$ Em capítulos anteriores apontamos elementos nessa ordem em músicas que encenam a interpelação disfórica de um personagem (Capítulo VII ou que se assemelham ao solilóquio acompanhado por instrumentos (no Capítulo IX, o "Blues del terror azul").
} 
A música começa com o eco longínquo de uma sirene policial. No projeto original do disco, esse efeito encadearia o início de "El show de los muertos" com o final da anterior, "Juan Represión”, que foi retirada do LP. Aquela canção não tratava sobre um agente da repressão de Estado, mas sobre a repressão de comportamentos personificada em um indivíduo amargo e rancoroso, que acabava preso do seu próprio delírio. Na escuta do disco como ele apareceu, não estando essa outra música, a sirene era o início absoluto. Logo começa a cantar Charly García com o acompanhamento musical que já descrevemos. No âmbito de um "show", a voz assume um locutor-apresentador em uma apelação mordaz, tanto pelo que oferece -os mortos- quanto pela indagação coloquial "quién quiere que se los muestre"? Apelo que se torna mais agressivo ainda ao sugerir um gosto ou atração por parte do espectador "elija usted en cuál de todas ellas se puso a pensar" ${ }^{150}$. Na segunda estrofe, a oferta integra o espectador à teatralidade, pedindo que escolha uma "mueca" (careta), e o pedido formulado na anterior se retoma, mas como referido ao pranto.

Depois há uma passagem para outro ritmo e outra melodia, com violão acústico, em que a voz perde o tom sarcástico, e, acompanhada pela de Nito Mestre, dá lugar a um locutor que já não é possível especificar como o apresentador que oferece e desafia. $\mathrm{O}$ solilóquio inquietante da voz, depois de lembrar brevemente um passado idílico, passa por interrogações e figurações que podemos relacionar a diversas encruzilhadas postas no campo cultural argentino dos 60-70, e que abordamos nos capítulos II e IV. A pergunta desconfiada sobre a possibilidade de agir no mundo ("qué estoy haciendo acá en esta calle con hambre") que caracterizou os poetas beatniks e reverberou em vários roqueiros; os ecos sartrianos do "ser em ato" ou "para si", que no primeiro rock argentino se relacionaram ao sujeito da mudança crítica, morrer para poder ser "si mesmo" e não o indivíduo ordinário de vida submetida. Mas o preço da liberdade é, agora, maior, o compromisso é mais exigido porque a morte vai tocar nossos corpos. Não há como estar "limpio de muerte": ou se assassina sem saber, ou se morre várias vezes para não ser $\operatorname{assim}^{151}$

\footnotetext{
150 A ocorrência da forma de tratamento "usted", infrequente no rock argentina para a construção do interlocutor da performance, é outro elemento, além dos que já mencionamos, que nos remete a esses gêneros de espetáculo.

${ }^{151}$ Inevitável referir-se aqui a outra composição de García na época, "El fantasma de Canterville”, na qual aparece uma hipérbole similar: "He muerto muchas veces acribillado en la ciudad".
} 
$\mathrm{Na}$ estrofe final, quando se retoma a musicalidade e o tom de espetáculo, a voz retorna em um dizer que já não é mordaz, mas apocalíptico, invocando uma violência que revele o oculto, "caigan las balas sanas aqui / que las sombras se hagan gritos". O questionamento final ao espectador sobre algo vermelho na calça atualiza a violência fora do "show". Se o apresentador no palco era cáustico, o "señor" espectador pode ser assassino sem saber. Os aplausos e gritos nervosos do público no final são precedidos pela imitação de uma figura da televisão da época, apelidada Tía Valentina, que fazia coluna de fofoca e cumprimentava com o clichê que se ouve: “Hola, lindísima gente!” Assim, o sarcasmo e finalmente o deboche soam fortemente, mas não apagam o tom de gravidade que também atravessa a música. De um modo angustioso, e particularizados em torno da morte -a própria, a dos outros, a dos desconhecidos- são retomados os interrogantes da dissidência inicial do campo do rock, e a rejeição por um estado de coisas que pode aproximá-lo do "compromisso" e até dos pressupostos da esquerda militante. Porém, a desolação já ganhou terreno. Na espera de que as sombras virem gritos -ou que tenham ido embora, como em "Eiti leda"- só resta o riso tenso, ou a "mueca" dos espectros.

\section{Un hombre que debe andar}

O recital de Adiós Sui Generis começou com “Instituciones". No filme, a canção ocupa os créditos iniciais, e no disco foi a primeira faixa. Alguns momentos dessa música permitem vislumbrar configurações enunciativas que só tempo depois se consolidarão no rock argentino. E sua reformulação preventiva diante da censura deixa ver, como tentaremos mostrar, as marcas recorrentes de uma regularização. No Apêndice, tanto as duas gravações no CD quanto as duas letras estão identificadas como "Instituciones - sem censura" e "Instituciones - publicada". A gravação "sem censura" corresponde a um recital no Teatro Coliseo em setembro de 1974, meses antes do lançamento do disco. Foi selecionada dentre as várias que existem em canais de colecionistas no Youtube, todas com compreensíveis deficiências sonoras, já que foram registradas com gravadores da época, e foi checada com dados e transcrições de Fernández Bitar ([1987] 2006, p 99) e de Provéndola (2015, p 93-95). 
Tanto na versão que se tocava sem censura como na definitivamente gravada, o canto dá corpo a uma primeira pessoa que se apresenta a partir de uma cenografia relacionável às do amanhecer que vimos ocorrer profusamente nos capítulos dedicados aos primeiros períodos do progressivo. Sua perspectiva é panorâmica, e se anuncia de um lugar de saber, mas o que vai explicar desse lugar é sua própria situação e propósito. As modificações entre uma versão e outra fazem com que essa visão seja diferente em cada uma, mas algo se manteve com a mesma força nas duas: a irrupção de uma voz disfórica, de uma perspectiva outra e oposta, trazida sem qualquer marca de discurso reportado ou de modalização.

Com efeito, o que faz Sui Generis no conjunto de cominações que começa com “Oye, m'hijo, las cosas están de este modo" e se encerra com a ordem "¡No preguntes más!" não tem precedentes até aquele momento, como configuração enunciativa, no rock argentino. Havia, como vimos no Capítulo VII, algumas formulações irônicas (poucas) em músicas de Moris e de Javier Martínez, mas "Instituciones" é a primeira ocasião, no rock argentino, em que aparece, diretamente e na mesma linearidade da voz, sem marcas de diferenciação, a voz do "inimigo", uma voz atribuível à racionalidade contra a qual se confronta ou se denuncia. Em épocas posteriores do rock argentino, depois da grande diversificação do campo com o final da ditadura, nos anos 80, essa forma de heterogeneidade será mais frequente. Cremos que a forte prescritividade e a tendência a uma delimitação muito nítida das entidades pessoais e suas perspectivas que observamos na primeira regularização do rock argentino são fatores relacionados à falta desse tipo de contra-perspectiva. E que sua aparição na produção última de Sui Generis pode ser vista como um dos acontecimentos discursivos que mais avança no sentido da desregularização parcial que tentamos explicar nos últimos dois capítulos.

No caso de "Instituciones", sua irrupção acompanha uma mudança de ritmo para um rock mais duro, que se mantém durante toda a parte da composição que corresponde a essa voz, e se apaga depois. Para Zariello (2008), trata-se de "un canto casi diabólico". Figuração feliz, se levarmos em conta que, nos 80, serão as bandas que mais incorporam o infernal às suas topografias e vozes precisamente aquelas em cujas músicas mais se joga com esse tipo de sobreposição de perspectivas. O exemplo mais nítido é a já mencionada Los Redondos, que, como nenhuma outra na Argentina, pôs em música e em vozes diferentes formas de subjugação dos sujeitos singulares ao funcionamento do estado e da economia. Em dois trabalhos nossos anteriores, Fanjul (2013b e 2013c), tratamos sobre a 
produção dessa banda nos 80 e 90, que já não se dá sob a circulação das divulgações do existencialismo ou do marxismo humanista, mas das leituras -mais ou menos "lidas", conforme o caso- de reflexões foucaultianas em torno do poder. Em uma dessas publicações tratávamos precisamente sobre a desestabilização das instâncias de pessoa e sobre esse tipo de contra-perspectiva nas músicas dos Redondos:

Diferencias entre agente y paciente, gozador y gozado, instrumentador e instrumento de la violencia del poder, están sometidas a diversos juegos enunciativos. A veces, juegos mostrados, visibles en la figuración, como el disimulo del enemigo en "Nuestro amo juega al esclavo", o en la forma lingüística, como el papel alternado de ejecutor y víctima ("te esnifo" / "me esnifan") en "Rock para los dientes". Pero también el paso no marcado de la voz de un posicionamiento a otro en relación con el sojuzgado: compartiendo su lugar o asumiendo una sorna que la acerca al beneficiario-verdugo. (FANJUL, 2013b, p 25-26)

Monteleone (1992, p 30), tratando sobre o rock dos 80 e em especial sobre os Redondos, emprega metaforicamente a imagem de um círculo traçado em rituais satânicos, propondo que o rock "no está dentro del círculo pero tampoco fuera porque su sitio no es el pretendido cielo de la pureza". O primeiro rock argentino, como vimos nos capítulos III e VII, não apresentava o trunfo da virtude nas suas narrativas, fator que o distanciou, de início, de certas representações de pureza. Mas boa parte das figurações no seu discurso, que temos observado ao longo desta tese, mostram sim uma orientação a delimitações nítidas, congruentes com condições sócio-históricas de produção nas quais se confrontavam enunciados que proclamavam fortemente sua pretensa localização sob um imperativo de "definição". Mesmo com seu forte caráter auto-reflexivo e supostamente despolitizado, o rock argentino é parte desse modo de proclamação. A ocorrência que estamos observando em Sui Generis aponta, nesse aspecto, em um direção diferente, de fazer ouvir a voz cruel, que só uma década depois, e em condições completamente diferentes, ganhará certa repetibilidade no rock do país.

As reformulações na letra de "Instituciones", realizadas às pressas e sob pressão, deram lugar a uma versão gravada na qual se percebem redundâncias de imagens que aparecem em estrofes anteriores: "temor a la soledad", "esperar en vano que me dieras tu mano", etc,. ficando a impressão de uma letra repetitiva e muito aquém da elaboração musical. Por outra parte, a reformulação apagou um traço central do locutor posto em cena, o gesto de resistência que enuncia ao recusar a liberdade apadrinhada. Na voz 
admoestadora, a vinculação direta com o poder político saiu, para ser substituída por um elemento da mídia -a rádio- e pelo tópico do quarto. E o que nos parece mais relevante, no escopo das regularidades que temos estudado nesta tese, é o que muda, entre ambas as versões, em relação ao deslocamento do ser, à sua disposição de movimento na topografia.

A própria auto-denominação, na canção primeira, inclui o deslocamento "soy un hombre que vino a andar" / "que debe andar". O propósito desse andar, irrenunciável, sem pedido de permissão, é "ir a llorar", o mesmo com que culmina a série de desejos formulada em "quiero ver, quiero ser, quiero entrar". Liberdade do ser em ato, em uma retirada que não renuncia ao lamento, porque é no pranto que a liberdade pode ainda ser exercida em situação. Na reformulação crispada pela ameaça, a enunciação lança mão de um lugar comum ao progressivo argentino:

Cuando el sol me viene a buscar

para llevar mis sueños a justo lugar

O sol que "percebe" ou "espera” pelo ser, como nas canções de Spinetta, Javier Martínez, Moris, Nebbia, mas que aqui precisa vir por ele. No crepúsculo, já se sabe o que foram apenas sonhos de terraza. A prosopopeia do entorno vem resguardar o herói da mudança crítica, que não será. 


\section{Considerações finais}

Nosso objetivo principal, como determinamos na Introdução, foi descrever e explicar como o campo do denominado "rock argentino" foi atravessado, nas suas primeiras épocas, por um processo de regularização discursiva. Hipotetizamos, no Capítulo II, que esse processo se articula em torno dos modos de representar o percurso de vida, os deslocamentos e mudanças dos seres representados, os modelos e contramodelos e o próprio processo de produção estética, prevendo que a observação do corpus acrescentaria outros objetos a esses. Também antecipamos ali regularidades em diversos níveis da configuração enunciativa, que fomos expondo nas análises. A mesma construção de hipótese nos levou a postular que essa regularização começa a registrar os efeitos de uma condensação de acontecimentos discursivos, que conduz para uma desregularização parcial. Nas seções finais dos capítulos IV , VIII e IX, já produzimos sínteses sobre os diferentes componentes afetados por essa regularização / desregularização, e tentamos ampliar o trabalho interpretativo e de elaboração de hipóteses para posições de sujeito relacionáveis a ela.

Denominamos esse processo analítico e argumentativo como produção de hipóteses não porque o apreciemos como meramente aproximativo, mas devido às considerações que fizemos no Capítulo I sobre como vemos a relação entre, por um lado, o reconhecimento e descrição de regularidades, e, por outro, a postulação de filiações para elas. Um modo de determinar nossa prática de análise, apontando o lugar que assumimos como pesquisador que tenta compreender, a partir da linguagem, práticas em uma formação social e em uma conjuntura histórica.

Cremos que dois fatores contribuíram para dar substância a esse processo, fazendo dele uma base suficiente (bastante para ser aceita ou não) para uma abordagem do rock argentino como espaço de atravessamento de discursos que contribuem para sua diferenciação como agrupamento discursivo na cultura de massa, à vez que expõem a instabilidade do agrupamento. O primeiro foi a intensidade do trabalho sobre a materialidade das canções e de outros textos, voltando constantemente sobre os eixos determinados para a análise e acrescentando objetos e figurações que iam aparecendo. $\mathrm{O}$ segundo foi a opção por partir de diferentes níveis de ausência e de exterioridade, acrescentando, à proposta explicativa, a efetividade desse exterior na regularização. 
Como também antecipamos no Capítulo I, cremos que o cotejo com uma abordagem analítica de outros campos nas práticas discursivas da Argentina da época daria bases para indagar, em trabalhos futuros, uma possível formação discursiva, como espaço não fechado de relações parafrásticas e de estabilização de saberes em torno de objetos, indagação que poderia partir de outros espaços periféricos da cultura de massa e da produção artística. Avaliamos que este trabalho, centrado em um desses espaços de práticas, o da "música progresiva", consegue dar bases para esse cotejo, que certamente levaria à reconfiguração de algumas hipóteses.

Pensamos que esta tese realiza contribuições em duas ordens: para os estudos discursivos e para a abordagem da música argentina de tradição popular e da produção cultural nesse país na segunda metade do século XX, principalmente para o estado de estudos sobre o que se denominou "rock argentino".

Quanto aos estudos do discurso, cremos que a tese oferece, em primeiro lugar, tudo que pode ser mobilizado pelos resultados de uma pesquisa que articulou problemas como as configurações enunciativas, os agrupamentos do discurso, a regularização e as posições de sujeito em relação a um campo abrangente, e com a extensão que consideramos necessária para dar conta de um processo em diferentes fases. $\mathrm{O}$ modo integral e não fragmentado de abordagem e de apresentação enseja questionamentos mais prolíficos sobre cada um dos componentes do problema e sobre os procedimentos de análise. Além dessa possibilidade, que de modo geral oferece todo trabalho de fôlego desenvolvido com critério e rigor, pensamos que há aspectos pontuais nos quais nosso presente trabalho pode realizar um aporte mais específico.

O trabalho analítico em torno das configurações enunciativas foi orientado, ao longo do trabalho todo, de modo a não perder de vista a necessidade de uma reflexão sobre a regularização e sobre a dimensão ideológica. Nesse sentido, cremos que o trabalho conseguiu mostrar de modo nítido e em torno de um campo específico, algo que AuthierRevuz ([1982] 2011, p 48) propõe como relação entre a "heterogeneidade mostrada" e a "heterogeneidade constitutiva". A observação da heterogeneidade mostrada permite aceder à representação que o locutor faz da enunciação, representação que "traduce el modo de negociación con la heterogeneidad constitutiva propia de ese discurso". Pensamos que o estudo realizado em torno da repetibilidade das configurações enunciativas que fomos caracterizando a partir do jogo enunciativo, das cenografias e da recorrência de determinados objetos foi eficaz para traçar um perfil dessa "negociação". 
A repetição como efeito de interdiscurso, em uma ordem que não é legível a partir da forma que se repete, mas de hipóteses sobre o confronto ideológico que atravessa a série estudada, determinando posições de sujeito. Cremos, também, que nosso trabalho permite perceber que a tensão regularizadora não pode ser fechada em cronologias. Mostramos que as diferentes forças co-ocorrem em uma mesma série e em uma mesma composição, e que a repetibilidade das suas marcas vai além das condições em que elas se desenvolveram, dando lugar a certa automatização.

Ainda no escopo dos estudos do discurso, cremos que a visão enunciativa sobre a prosopopeia, que desenvolvemos nos capítulos VI e VII contribui como revisão da estilística pela análise da enunciação. E, por outro lado, nossa proposta sobre uma discussão dos agrupamentos do discurso na cultura de massa que procure relacionar seu papel na conflituosidade social a aspectos da regularização discursiva que neles acontece atinge, nesta tese, um desenvolvimento mais nítido do que em trabalhos recentes que publicamos.

Pensamos que as maiores contribuições deste trabalho se situam em torno dos estudos sobre o rock argentino. Como antecipamos na Introdução, existem dois trabalhos prévios que realizaram uma abordagem integral que, por momentos, atenta a aspectos da discursividade, a partir de referenciais teóricos diferentes do que nós adotamos: o de Claudio Díaz (2005), que o autor situa em uma perspectiva "sócio-semiótica" e o de Diego Colomba (2010), localizado nos estudos literários. Com ambos dialogamos prolificamente ao longo deste texto, como em trabalhos nossos anteriores. A imensa maioria dos outros trabalhos acadêmicos existentes sobre o rock argentino, muitos dos quais referimos nesta tese, foram produzidos a partir de interrogantes sociológicos e /ou do jornalismo e os estudos da comunicação, havendo também outros que abordam casos ou autores pontuais a partir da crítica musical ou da poética.

Com exceção dos trabalhos de Díaz e de Colomba, podemos afirmar que a linguagem, verbal e não verbal, é tratada com visão conteudística. Pensamos no modo como Orlandi (1990, p 243-246) caracteriza essa tendência nas ciências sociais: desconhecimento do funcionamento do discurso, visão da ideologia como um "querer dizer", relação automática entre algumas marcas enunciativas o suposto "sujeito" discursivo. Ao ser esta tese o primeiro estudo produzido integralmente a partir de uma abordagem materialista do discurso como espaço de encontro do linguístico com o 
histórico, na perspectiva em que nos situamos no primeiro capítulo, pudemos oferecer uma visão do campo marcadamente diferente.

Pusemos em categorias discursivas perceptíveis na materialidade traços que, no acúmulo crítico em torno do rock argentino, têm sido aplainados ou reduzidos a etiquetas e abstrações temáticas, tais como "solidão", "procura interior", "naufrágio". Conseguimos, ainda, mediante a observação articulada de configurações enunciativas e construção de objetos, tirar da dimensão conteudística discussões sobre se o rock argentino em tal ou qual época "tratou" sobre o amor, a morte ou a política. Também contribuímos para revisar dicotomias presentes nessa tradição crítica, tais como "letras existenciais" vs "letras costumbristas" ou " realistas" e, de modo geral, para apresentar uma proposta multiforme sobre a presença do político no rock argentino. No mesmo caminho, postulamos relações de proximidade e de distância com algumas variedades do tango, abordando esse contraponto a partir dos papéis no conflito social e político, e da diferenciação em trono do melodramático. Cremos que conseguimos, dessa maneira, mostrar uma alternativa diferente dos lugares rotineiros em que essa comparação costuma ser feita, a partir de estereótipos temáticos e/ou de cristalizações lexicais.

Nosso trabalho também recupera um traço que aparece como estranho para a representação libertária habitualmente associada ao rock no mundo: o tom prescritivo fortemente presente na primeira época do rock argentino, e com reverberações em etapas posteriores. De todos os trabalhos que conhecemos sobre o campo, somente Colomba reparou nesse aspecto. Nós o situamos como relacionado, no jogo enunciativo, a delimitações rígidas das perspectivas de pessoa e, na dimensão da regularização discursiva, ao imperativo de "definição" e aos pré-construidos sobre a responsabilidade individual e o compromisso que, como tentamos demonstrar, atravessam o primeiro rock argentino de um modo diferente de como atravessaram produções da época mais aceitas como "políticas".

A respeito, precisamente, dessas distinções cristalizadas na revisão da cultura argentina dos 60 e 70, cremos que nosso trabalho dá bases para situar o "progressivo", ou "rock nacional" que nela surge como um espaço de contradições entre os posicionamentos em pugna, e não como adscrito a um deles ou à negação deles. E, o que consideramos mais importante, a tese chega a formular uma construção explicativa sobre formas específicas para essa contradição, e sobre exterioridades reveladoras que lhe são constitutivas. Valemo-nos, para essa construção explicativa, como cremos que não podia 
ser de outra maneira, de figurações que tentam denominar. Algumas, que deslocamos de reflexões em outros campos, como "humanocentrismo" ou "diferença dissidente". Outras, que nós postulamos, tais como "mudança crítica", "consternação", "retirada", "solidão consigo", "estados de amor", ou os empregos de "amanhecer", "quarto" e "refúgio" para descrever a cenografia. Cremos que são parte do trabalho necessariamente criativo que envolve a abordagem discursiva de séries, e não é nosso propósito consolidá-las como etiquetas fora desta análise. A escolha dos "casos" para os capítulos V, VII e X nos permitiu expor essa regularização e as contradições que lhe dão base na materialidade de textos musicais e não musicais que ocupam lugares muito destacados na construção histórico-crítica sobre o rock argentino. Isso também contribui para deixar nossa pesquisa em uma posição favorável para o diálogo com os estudiosos do campo.

Por último, esperamos que este trabalho abrangente que desenvolvemos sobre um campo específico contribua para os estudos sobre a produção cultural argentina do século XX, especialmente sobre sua música de tradição popular, e sobre as relações entre linguagem e política nessa formação social. 


\section{Referências}

ÁBALOS, Ezequiel. Rock de acá. Los primeros años. Buenos Aires: Edição do autor, 2009.

ADORNO, Theodor. "Reacción y progreso". [1930] Em: Escritos musicales IV. Trad. de Alfredo Brotons Muñoz e Antonio Gómez Schneekloth. Madrid: Akal, 2008, p 147-154. "O ensaio como forma”. [1958] Em: Notas de literatura I. Trad. de Jorge de Almeida. São Paulo: Editora 34, 2003, p 7-45.

AGUILAR, Gonzalo. "Treinta años de música. Historia personal." Em: TRAVERSA, Oscar (coord..) Treinta años de música para jóvenes. Buenos Aires: Ediciones de la Flor, 1998, p 28-78.

ALABARCES, Pablo. Entre gatos y violadores. El rock nacional en la cultura argentina. Buenos Aires, Colihue, 1993.

ALTAMIRANO, Carlos. "Peronismo y cultura de izquierda (1955-1965)". Latin American Studies Center Series, n 6. University of Maryland at College Park. 1992.

ALTHUSSER, Louis. «Idéologie et appareils idéologiques d'État (notes pour une recherche). Publicado originalmente na revista La pensée, Paris, n 151, 1970, p 67-125. Disponível on line na biblioteca virtual Les classiques des sicences sociales, da Université de Québec à Chicoutimi, http://classiques.uqac.ca/ último acesso em 22/2/2017

ALVES, Wanderlan. "Estética melodramática e canção popular como lugares de encontros culturais em Bolero, de Lisandro Otero." Letras de hoje, n 50-4, p 483-492.

ARISTÓTELES. Retórica. [s IVac] Introducción, traducción y notas por Quintín RANCIONERO. Madrid: Gredos, 1990.

AROSKIND, Ricardo. "El país del desarrollo posible" Em: JAMES, Daniel. Violencia, proscripción y autoritarismo (1955-1976). Buenos Aires: Editorial Sudamericana, 2003, p 63-115. 
AUTHIER-REVUZ, Jacqueline. "Heterogeneidad mostrada y heterogeneidad constitutiva: Elementos para un abordaje del otro en el discurso." [1982] Em: Detenerse ante las palabras. Estudios sobre la enunciación. Trad. de Alma Pedrretti de Bolón. Montevidéu: Fundación de Cultura Universitaria, 2011.

BAKHTIN. Mikhail. "Os gêneros discursivos”. [1953] Em: Estética da criação verbal. Trad. Maria Ermantina Galvão Pereira. São Paulo: Martins Fontes, 1997, p 277-326.

BAREA, Federico (ed.) Argentina Beat. Derivas literarias de los grupos Opium y Sunda (1963-1969). Buenos Aires: Caja Negra, 2016.

BAREI, Silvia. "Con-versiones. De la metáfora al orden metafórico." Em: VITALE, María, e SCHAMUN, María (comp.) Tendencias actuales en estudios retóricos. La Plata: EDULP, 2012, p 213-227.

BEACCO, Jean-Claude. "Trois perspectives linguistiques sur la notion de genre discursif." Langages, n 153, 2004, p 109-119.

BELL, Daniel. Las contradicciones culturales del capitalismo. Trad. de Néstor Míguez. México: Alianza, 1989.

BENEDETTI, Sebastián, e Graziano, Martín. Estación imposible. Expreso imaginario y el periodismo contracultural. Buenos Aires: Gourmet Musical, 2016.

BENVENISTE, Émile. "De la subjetividad en el lenguaje". [1958] Em: Problemas de lingüística general. V 1. Trad. de Juan Almela. México: Siglo XXI, 2002, p 179-187.

"Semiología de la lengua". [1969] Em: Problemas de lingüística general. V. 2. Trad. de Juan Almela. México: Siglo XXI, 2002, p 47-69.

BERTI, Eduardo. "Hubo un tiempo que fue hermoso. El regreso de Sui Generis o la historia a través de las canciones." Em: Revista Tres Puntos, Buenos Aires, n 132, 2000, p 60-68.

Spinetta. Crónicas e iluminaciones. Buenos Aires: Planeta, 2014. 
BÍBLIA DE JERUSALÉM. Edição coordenada por Gorgulho, Gilberto; Storniolo, Ivo, e Anderson, Ana. São Paulo: Ed Paulus, 2002.

BLANCO, Alejandro. "Ideología, cultura y política: la 'Escuela de Frankfurt' en la obra de Gino Germani”. Em: Prismas. Revista de Historia Intelectual, n 3, 1999, p 95-116.

BLANCO, Oscar e SCARICACIOTTOLI, Emiliano. Las letras de rock en Argentina. De la caída de la dictadura a la crisis de la democracia. 1983-2001. Buenos Aires: Colihue, 2014.

BROOKS, Peter. "Une esthétique de 1'étonnement: le mélodrame." Em: Poétique. Revue de théorie et d'analyse littéraires. N 19, 1974, p 340-356.

BOURDIEU, Pierre. "El mercado de los bienes simbólicos" [1971]. Trad. de Alicia Gutiérrez. Em: El sentido social del gusto. Elementos para una sociología de la cultura. Buenos Aires: Siglo XXI, 2010, p 85-152.

“Algunas propiedades de los campos" [1976]. Trad. de Alberto Escurdia. Em:__Campo de poder, campo intelectual. Itinerario de un concepto. Buenos Aires: Editorial Quadrata, 2003, p 89-93.

CAMBIASSO, Norberto. "El trapecio del tiempo (se alejó de mí). Sobre Miguel Abuelo et Nada." Em: 10 discos del rock nacional presentados por 10 escritores. Buenos Aires: Paidós, 2013.

CAMPRA, Rosalba. Como con bronca y junando. La retórica del tango. Buenos Aires: Edicial, 1996.

CARASSAI, Sebastián. Los años setenta de la gente común. La naturalización de la violencia. Buenos Aires: Siglo XXI, 2014.

CARNICER, Lucio. "Los spirituals porteños de Manal”. EM: Atas do II Congresso Internacional de Estudos do Rock. Cascavel: UNIOESTE, 2015, p 1-11.

CARNICER, Lucio e DÍAZ, Claudio. "El Abuelo, ¿hijo de quién era? El papel de Miguel Abuelo en la fundación del rock argentino." Em: Actas del IV Congreso Latinoamericano de la Asociación Internacional para el Estudio de la Música Popular, 2002, p 1-11. 
CASAS, Fabián. Oda. Buenos Aires: Libros de Tierra Firme, 2003. Los Lemmings y otros. Barcelona: Alpha Decay, 2011.

COCCO, Marta. La resistencia cultural a la dictadura militar argentina de 1976. Clandestinidad y representación bajo el terror de Estado. Tese de Doutorado. King's College. London. 2011. 253f.

COLOMBA, Diego. Letras de rock nacional. Géneros, estilos y transposiciones. Tese de Doutorado. Universidad Nacional de Rosario, 2010, 244p.

CONDE, Oscar (org.). Poéticas del rock. Buenos Aires: Marcelo H Oliveri Editor, 2007.

COURTINE, Jean-Jacques. «Quelques problèmes théoriques et méthodologiques en analyse du discours, à propos du discours communiste adressé aux chrêtiens. » Langages, n. $62,1981, \mathrm{p} 9-126$.

CRENZEL, Emilio. "Sebastián Carassai, Los años setenta de la gente común. La naturalización de la violencia, Buenos Aires, Siglo XXI, 2013, 329 p.». Nuevo Mundo Mundos Nuevos [Online], Resenhas e ensaios historiográficos, 2014, http://nuevomundo.revues.org/66159

CRUZ, Claudio. "Contribuições para uma arqueloologia do compadrito borgeano". Em Variaciones Borges, n 31, 2011, p 57-70.

DACAL, Pablo. “Asesinato del rock”. [2006] Em: GRINBERG, M. Cómo vino la mano. Orígenes del rock argentino. Buenos Aires, Gourmet Musical, 2008, p 207-208.

DAPIEVE, Arthur. BRock. O rock brasileiro dos anos 80. São Paulo: Editora 34, 1995.

DEMETRIO. Sobre el estilo. [sec III ac?] Edição de Carlos García Gual. Madrid: Gredos, 1979.

DÍAZ, Claudio. Libro de viajes y extravios: un recorrido por el rock argentino 1965 1985. Córdoba: Narvaja Editor, 2005. 
DIEZ OLEA, Diego. "El rock de La Cueva. Un modo de composición oral en las canciones de Moris, Manal y Tanguito.” Em: CONDE, Oscar (org.). Poéticas del rock. Buenos Aires: Marcelo H Oliveri Editor, 2007.

DI TULIO, Ángela, e MALCOURI, Marisa. Gramática del español para maestros y profesores del Uruguay. Montevideu: ANEP / Pro LEE, 2012.

DUCROT, Oswald. [1972] Princípios de semântica linguística. Dizer e não dizer. Trad. de Carlos Vogt. São Paulo: Cultrix, 1977.

Énonciation. In: Encyclopaedia Universalis (edição on line para subscriptores). http://www.universalis.fr/encyclopedie/enonciation/, 1980.

Edicial, 2001.

El decir y lo dicho. [1984] Trad. de Sara Vasallo. Buenos Aires:

ELKAÏM-SARTRE, Arlette. [1996] "Situación de la conferencia". Em: SARTRE, JeanPaul. El existencialismo es un humanismo. Edição de Arlette Elkaïm-Sartre. Barcelona: Edhasa, 2009, p 6-18.

ESTÉBANEZ CALDERÓN, Demetrio. Diccionario de términos literarios. Madrid: Alianza, 2003.

FANJUL, Adrián. Português e espanhol: línguas próximas sob o olhar discursivo. São Carlos: Ed. Claraluz, 2002.

"Delimitación enunciativa de héroes en letras de música urbana de Brasil y Argentina". Em: Actas del XIV Congreso de ALFAL (Asociación de Lingüística e Filología de América Latina). Monterrey, México, 2005, s/n de página.

"Acúmulos e vazios da pesquisa sobre o rock da Argentina". Latin American Music Review. No 29-2, 2008, p. 121-143.

"Loucura, 'realidade' e deslocamento em cenografias pioneiras do rock". Anais do V Congresso Brasilerio de Hispanistas e I Congresso Internacional da Associação Brasileira de Hispanistas. ROJO, Sara et al (org.). Belo Horizonte: Faculdade de Letras da UFMG, 2009a, p 2239-47.

"Escenas enunciativas en la representación de la violencia de estado en el rock de Brasil y Argentina”. Actas completas del IV Coloquio de Investigadores en Estudios del Discurso y I Jornadas Internacionales de Discurso e Interdisciplina. Universidad Nacional de Córdoba. 2009b, p 194-205. 
"Enunciadores en el rock argentino. Elementos para una comparación con Brasil.”Letr@Viv@ ,10-1, 2010,p 143-157.

"Tallado y demarcación. Composiciones transpuestas entre el rock de Brasil y de Argentina." Lingua(gem) em discurso, n. 13-2, 2013a, p 359-381.

"Topografías del artista y desestabilización enunciativa en el rock de argentina”. Em: SANTOS, Margareth; MARTÍN, Ivan. e FANJUL Adrián. (org.): Atas do VII Congresso Brasileiro de Hispanistas, São Paulo: Associação Brasileira de Hispanistas, 2013b, p 15-22.

"Entre chacales y juguetes perdidos. Discursivização da resistência em uma etapa do campo do rock na Argentina." Anais do I Congresso Internacional de Estudos do Rock. Cascavel, 2013c, s/n, disponível em http://www.congressodorock.com.br/evento/anais/2013/artigos/2/artigo_simposio_1_60 _adrianpf@yahoo.com.pdf

"Life Trajectories and Dejuvenilization in Argentine Rock". VILA, Pablo. (ed.) Music and Youth Culture in Latin America. Identity Constructions Processes from New York to Buenos Aires. New York: Oxford University Press, 2014a, p 261-283.

"Conhecendo assimetrias. A ocorrência de pronomes pessoais." Em: FANJUL, Adrián, e GONZÁLEZ, Neide (orgs.). Espanhol e português brasileiro. Estudos comparados. São Paulo: Parábola, 2014b, p 29-50.

"Posse, domínio, apresentação, existência". Em: FANJUL, Adrián, e GONZÁLEZ, Neide (orgs.). Espanhol e português brasileiro. Estudos comparados. São Paulo: Parábola, 2014c, p 159-184.

"Unidades do discurso, indagação comparativa e proximidade linguística: perspectivas e limites da categoria de 'gênero'." Letras de hoje, v. 50, n. 4, p 508-517, 2015.

A pessoa no discurso. Português e espanhol: novo olhar sobre a proximidade. São Paulo: Parábola, 2017.

FAUSTO, Boris, e DEVOTO, Fernando. Brasil e Argentina. Um ensaio de história comparada (1850-2002). São Paulo: Editora 34, 2004.

FAVARETTO, C. Tropicália, alegoria, alegria. Cotia: Atelié Editorial, 1995.

FAVORETTO, Mara. Charly en el país de las alegorías. Buenos Aires: Gourmet Musical, 2014. 
FERNÁNDEZ BITAR, Marcelo. [1987] Historia del rock en Argentina. Edición digital para Rock.com.Ar. Buenos Aires: 2006, disponível em http://www.rock.com.ar/historia/index.shtml

FERNÁNDEZ L’HOESTE, Héctor, e VILA, Pablo. Cumbia! Scenes of a Migrant Latin American Music Genre. Duke University Press, 2013.

FERNÁNDEZ RAMÍREZ, Salvador. Gramática española. Vol. 4. El verbo y la oración. Edição completada e preparada por Ignacio Bosque. Madrid: Arco Libros, 1987.

FISCHERMAN, Diego. Efecto Beethoven. Complejidad y valor en la música de tradición popular. Buenos Aires: Paidós, 2013.

FLACHSLAND, Cecilia. "Banderas en mi corazón. Militantes y rockeros. Un ensayo sobre las subjetividades juveniles en los 60." Em Tram[p]as de la comunicación y la cultura, n 52, 2007, p 21-25.

FLORES, Rafael. "Los letristas del tango y su ambiente". Cuadernos Hispanoamericanos, n 445, 1987, p 99-105.

FRITH, Simon. Ritos de la interpretación. Sobre el valor de la música popular. [1998] Trad de Fermín Rodríguez. Buenos Aires: Paidós, 2014.

FOUCAULT, Michel. L’archéologie du savoir. Paris: Gallimard, 1969.

La arqueología del saber. [1969] Trad. de Aurelio Garzón del Camino. México: Siglo XXI, 1972.

El orden del discurso. [1970] Trad. de Alberto González Troyano.

Buenos Aires: Tusquets, 2008.

FUCHS, Catherine. La paraphrase. Paris: Presses Universitaires de France, 1982.

GARCÍA NEGRONI, María Marta. "La distinción Pretérito Perfecto Simple / Pretérito Perfecto Compuesto. Un enfoque discursivo." Em: Revista Iberoamericana de Discurso y Sociedad, n 2, 1999, p 45-60. 
GARRAMUÑO, Florencia. Modernidades primitivas. Tango, samba e nação. Trad. de Rómulo Monte Alto. Belo Horizonte: Ed. Da UFMG, 2009.

GOBELLO, Marcelo. Banderas en tu corazón. Apuntes sobre el mito de Los Redondos. Monte Grande: Prego, 1999.

GODOY SEPÚLVEDA, Eduardo. "Dictadura militar y lucha armada en Argentina. La fuga de Rawson y la masacre de Trelew (1972)." Em: Tiempo histórico, n 4, 2012, p 2341.

GONZÁLEZ, Daniel "Silencios de entonces". Em: Revista Tres Puntos, Buenos Aires, n $132,2000, \mathrm{p} 63$.

GORDILLO, Mónica. "Protesta, rebelión y movilización: de la resistencia a la lucha armada (1955-1973)." Em: JAMES, Daniel. Violencia, proscripción y autoritarismo (1955-1976). Buenos Aires: Editorial Sudamericana, 2003, p 329-380

GRAZIANO, Martín. Cancionistas del Río de la Plata. Después del rock: una música popular para el siglo XXI. Buenos Aires: Gourmet Musical, 2011.

GRINBERG, Miguel "Revolución versus revolución”. Em: Eco contemporáneo, n 1. Buenos Aires: Angel Press, 1961, p 62-65,

[1977] "El invierno del '65”. Em Cómo vino la mano. Orígenes del rock argentino. Buenos Aires: Gourmet musical, 2008, p 39-47.

Cómo vino la mano. Orígenes del rock argentino. Buenos Aires: Gourmet musical, 2008.

GUIMARÃES, Eduardo. Semântica do acontecimento. Campinas: Pontes, 2005.

HENRY, Paul. "Construções relativas e articulações discursivas." 1975] Trad. E João Wanderlei Geraldi e Celene Margarida Cruz. Em: Cadernos de Estudos Línguísticos, $\mathrm{n}$ 19, p 43-64. 
HIGA, Evandro. Polca paraguaia, guarânia e chamamé. Estudos sobre três gêneros musicais em Campo Grande-MS. Campo Grande: Editora da UFMS, 2010.

HORKHEIMER, Mark, e ADORNO, Theodor. "Industria cultural. Ilustración como engaño de masas." [1944] Em: Dialéctica de la ilustración. Fragmentos filosóficos. Trad. de Juan José Sánchez. Madrid: Trotta, 1994, p165-212.

JACOBY, Roberto. El deseo nace del derrumbe. Acciones, conceptos, escritos. Edição a cargo de Ana Longoni. Barcelona: Ediciones de la Central, 2011.

JAMES, Daniel (dir.). Violencia, proscripción y autoritarismo (1955-1976). Buenos Aires: Sudamericana, 2007.

JITRIK, Noé. [1966] "Poder e impotencia de la literatura". Em: SARTRE, Jean-Paul; BEAUVOIR, Simone de; SEMPRÚN, Jorge; BERGER, Yves; FAYE, Jean-Pierre, e RICARDOU, Jean. ¿Para qué sirve la literatura? Buenos Aires: Proteo, 1970.

KING, John. El Di Tella y el desarrollo cultural argentino en la década del sesenta. Buenos Aires: Ediciones Gaglianone, 1985.

KLEIBER, Georges. Problèmes de référence: descriptions définies et noms propres. Paris: Klincksiek, 1981.

KLEIMAN, Claudio. "100 mejores discos del rock nacional”. Rolling Stone Argentina, n $109,2007$.

KOHAN, Martín. "Dos ausentes en Ezeiza. Poesía y política en el nuevo siglo." Em: Cuadernos de recienvenido, n 20, 2007, p 5-17.

KOZAK, Claudia. Discursos mediados. Transformaciones de las prácticas artísticoverbales en el marco de la cultura mediática argentina contemporánea. Tese de Doutorado inédita. Universidad de Buenos Aires, 2000.

LACA, Brenda. "Presencia y ausencia de determinante". Em: BOSQUE, Ignacio, e DEMONTE, Violeta (dir.). Gramática descriptiva de la lengua española. 3v. Madrid: Espasa-Calpe, 1999, p 891-928. 
LAUSBERG, Heinrich. Manual de retórica literaria. Fundamentos de una ciencia de la literatura. Vol II. [1967] Trad. de José Pérez Risco. Madrid: Gredos, 1991.

LECHUGA, David. La prosopopeya en las Soledades de Luis de Góngora. Tesis de Maestría en Letras Españolas. Universidad Nacional Autónoma de México, 2015, 121p.

LERNOUD, Pipo. "El frenético mundo de los artistas". Em: Expreso Imaginario, n 25, Buenos Aires, agosto de 1978, p 36.

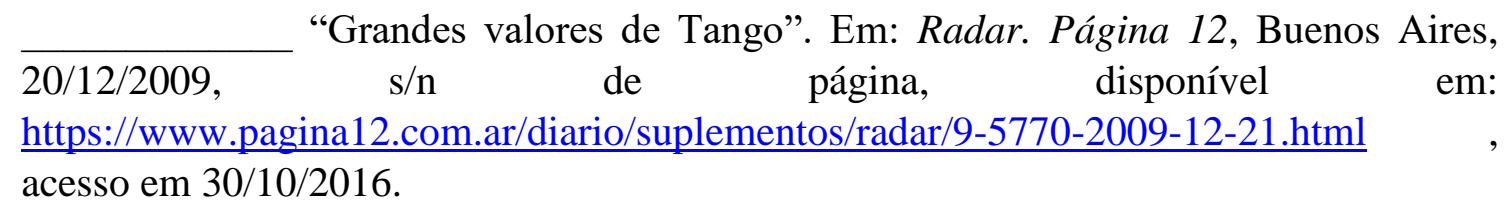

LERNOUD, Pipo (org.) Enciclopedia Rock Nacional 30 años. Buenos Aires: Ediciones Mordisco, 1996.

LEVIN, Florencia. "Representaciones sobre la violencia a través del humor gráfico en la Argentina de la década de 1970. El caso del diario Clarín.” Em: BOHOSLAVSKY, Ernesto; FRANCO, Marina; IGLESIAS, Mariana, e LVOVICH, Daniel (comp.). Problemas de historia reciente del Cono Sur. Volumen II. Buenos Aires: Prometeo, 2010, p 201-222.

LINCUIZ, Diego. "De la periferia al centro. Los letristas de tango en la sociedad modernizada." Em: FOFFANI, Enrique (ed.). Controversias de lo moderno. La secularización en la historia cultural latinoamericana. Buenos Aires: Katatay Ediciones, 2010, p 163-184.

LONGONI, Ana. "Oscar Masotta: vanguardia y revolución en los sesenta”. Em: Ramona. Revista de artes visuales, n 45, 2004, p. 4-29.

LOTMAN, Iuri. La semiosfera. 3 vol. Trad. de Desiderio Navarro. Madrid: Cátedra, 1996.

LUCAKS, Georg. [1947] Existencialismo ou marxismo. Trad. de Carlos Nelson Coutinho. Rio de Janeiro: Editora Senzala, 1967. 
MAC DONALD, Ian. The Beatles. Revolución en la mente. Madrid: Celeste Ediciones, 2000.

MAINGUENEAU, Dominique. O contexto da obra literária. Trad. de Sírio Possenti. São Paulo: Martins Fontes, 2001.

Cenas da Enunciação. Trad. de Maria Cecília Perez de Sousa e Silva. São Paulo: Parábola, 2008.

MALDIDIER, Denise. "Elementos para a história de uma análise do discurso na França". Trad. de Mónica Zoppi Fontana e Maria C. Leandro Ferreira. Em: ORLANDI, Eni. (org.). Gestos de leitura. Campinas: Ed. da UNICAMP, 1994, p 9-22.

MANZANO, Valeria. "Ha llegado la nueva ola. Música, consumo y juventud en la Argentina (1955-1966)." Em: COSSE, Isabella; FELITTI, Karina, e MANZANO, Valéria (eds.) Los 60 de otra manera: vida cotidiana, género y sexualidades en la Argentina. Buenos Aires: Prometeo, 2010, p 19-60.

"Rock National and Revolutionary Politics. The Making of a Youth Culture of Contestation in Argentina (1966-1976)." Em: The Americas, n 70-3, 2014, $\mathrm{p}$ 393-427.

MANZANO, Valeria, e PASQUALINI, Mauro. "Aportes a una historia del rock nacional”. Em: Rock \& Roll. Cultura de jóvenes. Buenos Aires: Ed. La Llave, p 68-93.

MARCHESE, Angelo, e FORRADELAS, Joaquín. Diccionario de retórica, crítica y terminología literaria. Barcelona: Ariel, 1994.

MARCOS MARIN, Francisco. Estudios sobre el pronombre. Madrid: Gredos, 1978.

MARTÍN-BARBERO, J. Dos meios às mediações. Comunicação, cultura e hegemonia. Trad de Ronald Polito e Sérgio Alcides. Rio de Janeiro: Editora UFRJ, 2008.

MATOS, Cláudia. (org.) Ao encontro da palavra cantada. Poesia, música e voz. Rio de Janeiro: 7 Letras, 2001.

MAYORAL, José Antonio. Figuras retóricas. Madrid: Síntesis, 1994. 
MAZALEYRAT, Jean, e MOLINIÉ, Georges. Vocabulaire de la stylistique. Paris: PUF, 1989.

MENDIKOETXEA, Amaya. "Construcciones inacusativas y pasivas". Em: Bosque, Ignacio, e Demonte, Violeta (dir.) Gramática descriptiva de la lengua española. 3 v. Madrid: Espasa-Calpe, 1999, p 1575-1629.

MENEZES, A. Entre pátrias, pandeiros e bandoneones. O embate entre vozes marginais e disciplinadoras em composições de samba e tango (1917-1945). Tese de Doutorado. Universidade de São Paulo, 2012. Disponível em: http://www.teses.usp.br/teses/disponiveis/8/8145/tde-13032013-111737/pt-br.php

MERELES, Hernán. "El proceso represivo en los años 70 constitucionales. De la 'depuración' interna del peronismo al accionar de las organizaciones paraestatales." Em: Águila, Gabriela; Garaño, Santiago, e Scatizza, Pablo (comp.) Represión estatal y violencia paraestatal en la historia reciente argentina. Nuevos abordajes a 40 años del golpe de Estado. La Plata: Editora da Universidad Nacional de La Plata, 2016, p 99-123.

MOISÉS, Massaud. Dicionário de termos literários. $12^{\mathrm{a}}$ edição revista e ampliada. São Paulo: Cultrix, 2004.

MONTELEONE, Jorge. "El infierno encantador. Violencia y poesía del rock." Em: Espacios de crítica y producción, n 11, 1992, p. 29-33.

“Cuerpo constelado. Sobre la poesía del rock argentino.". Cuadernos Hispanoamericanos, n 517-519, 1993, p 401-420.

NAPOLITANO, Marcos. A síncope das idéias, A questão da tradição na música popular brasileira. São Paulo: Ed. Fundação `Perseu Abramo, 2007.

"Political Activists, Playboys adn Hippies. Musical Movements and Symbolic Representations of Brazilian Youyh in the 1960s." Em: VILA, Pablo. (ed.) Music and Youth Culture in Latin America. Identity Constructions Processes from New York to Buenos Aires. New York: Oxford University Press, 2014, p 204-224.

NOVARO, Marcos, e PALERMO, Vicente. La dictadura militar (1976-1983). Del golpe de estado a la restauración democrática. Buenos Aires: Paidós, 2011.

OLIVEIRA, Paulo da Costa e Silva. "Canção de amor de menos. Sentimento e sensação na música de Tom Jobim.” Em: GIUMBELLI, Emerson; DINIZ, Júlio César, e NAVES, 
Santuza (org.) Leituras sobre música popular: reflexões sobre sonoridade e cultura. Rio de Janeiro: 7 Letras, 2008, p 235-250.

ORLANDI, Eni. Terra à vista. Discurso do confronto: velho e novo mundo. São Paulo: Cortez, 1990.

Petrópolis: Vozes, 1996.

Interpretação. Autoria, leitura e efeitos do trabalho simbólico.

«Ler Michel Pêcheux hoje ». Em: ORLANDI, Eni (org.) Análise de discurso. Michel Pêcheux. Campinas: Pontes, 2011, p 11-20.

PALERMO, Vicente. Reseña: "Los años setenta de la gente común. La naturalización de la violencia. Sebastián Carrasai.” Em: Prismas, n 18, 2014, p 342-344.

PAXSON, James; The poetic of personification. New York: Cambridge University Press, 1994

PÊCHEUX, Michel. "Análise automática do discurso" [1969]. Em: Gadet, Françoise, e Hak, Tony. Por uma análise automática do discurso: uma introdução à obra de Michel Pêcheux. Trad. Bethânia Mariani. Campinas: Ed. da UNICAMP, 1997, p 61-161.

Semântica e discurso. Uma crítica à afirmação do óbvio. [1975] Trad. de Eni Orlandi. Campinas: Ed. da UNICAMP, 1997.

"Leitura e memória: projeto de pesquisa". [1982] Trad de Tânia Clemente de Souza. Em: ORLANDI, Eni (org.). Análise de discurso. Michel Pêcheux. Campinas: Pontes, 2011, p. 141-150.

O discurso. Estrutura ou acontecimento. [1983] Trad. de Eni Orlandi. Campinas: Pontes, 2002.

"Papel da memória". [1983] Trad. de José Horta Nunes. Em:

ACHARD, Pierre. et. al. Papel da memória. Campinas: Pontes, 2007, p 49-56.

"Metáfora e interdiscurso" [1984]. Trad de Eni Orlandi. Em: ORLANDI, Eni (org.). Análise de discurso. Michel Pêcheux. Campinas: Pontes, 2011, p 151-161.

PÊCHEUX, Michel e FUCHS, Catherine. «Mises au point et perspectives à propos de l'analyse automatique du discours ». Em: Langages, n. 37, 1975, p. 7-80.

PÉREZ, Martín. "Los hijos de la lágrima". Em Radar, caderno de Página 12, edição e 12/2/2012. Buenos Aires, 2012, edição digital s/n de página. Disponível em: 
https://www.pagina12.com.ar/diario/suplementos/radar/subnotas/7690-1638-2012-02$\underline{12 . h t m l}$

PINTOS, Víctor. "El tesoro que estaba perdido". Rock.com.ar, 8/8/2005. Disponível em: http://web.archive.org/web/20140216114702/http://www.rock.com.ar/blog/el-tesoroque-estaba-perdido/

PIZARNIK, Alejandra. Antología poética. Seleção e organização de Adrián Pablo Fanjul. Buenos Aires: Cántaro, 1997.

PODESTÁ, Carlos. "Las mañas de Pelo". Em Revista Periscopio, Buenos Aires, n 48, 4 de agosto de 1970, p 36.

POLIMENI, C. Bailando sobre los escombros. Historia crítica del rock latinoamericano. Buenos Aires: Biblos, 2001.

PONZA, Pablo. "Existencialismo y marxismo humanista en los intelectuales argentinos de los sesenta". Em: Nuevo Mundo Mundos Nuevos [Online], Debates. On line desde 13/10/2006. http://nuevomundo.revues.org/2923 ; DOI : 10.4000/nuevomundo.2923

PROVÉNDOLA, Juan Ignacio. Rockpolitik. 50 años de rock nacional y sus vínculos con el poder político argentino. Buenos Aires: EUDEBA, 2015.

PUJOL, Sergio. "Rebeldes y modernos. Una cultura de los jóvenes.” Em: JAMES, Daniel (dir) Violencia, proscripción y autoritarismo (1955-1976). Buenos Aires: Sudamericana, 2007a, p 281-328

"La anunciación del rock. Identidad, divino tesoro." Tram[p]as de la comunicación y la cultura, n 52, 2007b, p 14-20.

La década rebelde. Los años 60 en la Argentina. Buenos Aires: Emecé, 2002.

Rock y dictadura. Crónica de una generación (1976-1983). $3^{\mathrm{a}}$ edição. Buenos Aires: Booket, 2013.

"Escúchame, alúmbrame. Apuntes sobre el canon de 'la música joven' argentina entre 1966 y 1973." Em: Apuntes de investigación del CECYP, n 25, 2015, p $11-25$. 
QUINTILIANUS [sec I] Institutionis Oratoriae. Trad. de Harold E. Butler. 1922. Em Lacus Curtius, Universidade de Chicago, http://penelope.uchicago.edu/Thayer/e/roman/texts/quintilian/institutio_oratoria/home.h $\underline{\mathrm{tml}}$

Radesmacher. Teubneri, 1965.

Institutionis Oratoriae. Edição em latim de Ludwig

RODRÍGUEZ AGÜERO, Laura. "Maestras y madres. Géneros y lucha docente en el post Mendozazo (1972-1973)". Em: Milcayac. Revista digital de ciencias sociales, n 1, 2014, p 75-98.

ROZITCHNER, León. [1966] "La izquierda sin sujeto”. Em: Pensamiento crítico, n 12. Habana. 1968, p 151-183.

RUIZ, Pablo. "Luis Alberto Spinetta. La forma de la canción.” Revista de crítica literaria latinoamericana, n 75, 2012, p 491-498.

SARLO, Beatriz. La batalla de las ideas (1943-1973). Biblioteca del pensamiento argentino VII. Buenos Aires: Emecé, 2001.

Tempo passado. Cultura da memória e guinada subjetiva. São Paulo: Companhia das Letras/ Belo Horizonte: Editora UFMG, 2007.

SARTRE, Jean-Paul. [1943] O ser e o nada. Ensaio de ontologia fenomenológica. Trad. de Paulo Perdigão. Rio de Janeiro: Vozes, 1997.

"Présentation des Temps Modernes". Em Les Temps Modernes, n 1, Paris: Gallimard, 1945. Extraído da página http://jpsartre.free.fr/page2.html

[1945] El existencialismo es un humanismo. Edição de Arlette ElkaïmSartre. Trad. de Vitoria Praci de Fernández. Barcelona: Edhasa, 2009.

Ática, 2004.

[1948] Que é a literatura? Trad. de Carlos Felipe Moisés. São Paulo:

[1965] "Los intelectuales". Em: Escritos políticos, vol 3. El intelectual y la revolución. Madrid: Alianza Universidad, 1987, p 91-141.

SCHANTON, Pablo. "El sabor agridulce de aquellos años violentos". Em: Clarín. Buenos Aires, 6/2/2013. Disponível em http://www.clarin.com/sociedad/sabor-agridulceanos-violentos_0_H16QK4iiPXx.amp.html , acesso em 20/2/2017 
SEMÁN, Pablo e VILA, Pablo. "Rock chabón e identidad juvenil en la Argentina neoliberal." Em: FILMUS, D. (org.) Los noventa. Política, sociedad y cultura en América Latina y Argentina de fin de siglo. Buenos Aires: Eudeba, 2001, 225-258.

SERRANI, Silvana. "Análise de ressonâncias discursivas para estudo da identidade linguístico-cultural” Trabalhos em Lingüística Aplicada, n. 24, 1994, p. 79-90.

SEVERIANO, Jairo. Uma história da música popular brasileira. Das origens à modernidade. São Paulo: Editora 34, 2008.

SIGAL, Silvia. Intelectuales y poder en Argentina. La década del sesenta. Buenos Aires: Siglo XXI, 2002.

SILVA, Franklin. Sartre e o humanismo. São Paulo: Barcarolla, 2013.

SOUZA, Pedro de. "A cidade nas canções. Sentidos de perda e pertencimento.” Em: Cadernos de Estudos Linguísticos, n 53, v 2, 2011, p 113-124.

STEIMBERG, Oscar. Semiótica de los medios masivos. El pasaje a los medios de los géneros populares. Buenos Aires: Atuel, 1998.

STEIMBERG, Oscar, e TRAVERSA, Oscar. Estilo de época y comunicación mediática. Buenos Aires: Atuel, 1997.

TEACH, César. "Golpes, proscripciones y partidos políticos". Em: JAMES, Daniel. Violencia, proscripción y autoritarismo (1955-1976). Buenos Aires: Editorial Sudamericana, 2003, p 17-62.

TERÁN, Oscar. Nuestros años sesentas. Buenos Aires: Ed. Puntosur, 1991. Historia de las ideas en la Argentina. Diez lecciones iniciales, 18101980. Buenos Aires: Siglo XXI, 2008.

THOMASSEAU, Jean-Marie. El melodrama. Trad. de Marcos Lara. México: Fondo de Cultura Económica, 1984. 
TODOROV, Tzvetan. Introdução à literatura fantástica. Trad. de Maria Clara Correa Castello. São Paulo: Perspectiva, 1975.

Litérature et signification. Paris: Larousse, 1967.

TOSCANO, Guillermo, e WARLEY, Jorge. El rock argentino en cien canciones. Buenos Aires: Colihue, 2003.

VILA, Pablo (1985): "Rock nacional. Crónicas de la resistencia juvenil." Em: JELIN, Elizabeth (org.): Los nuevos movimientos sociales. Buenos Aires: Centro Editor de América Latina, p 83-148.

(1987): “El rock. Música argentina contemporánea.” Em: Punto de Vista No 30, Buenos Aires, pág. 23-29.

VELOSO, Caetano. Verdade tropical. São Paulo: Companhia das Letras, 2008.

VOLÓSHINOV, Valentin. El marxismo y la filosofía del lenguaje. [1929] Trad. Tatiana Bubnova. Buenos Aires: Godot, 2009.

WALES, Katie. A Dictionary of Stylistics. Londres: Longman, 1989.

WATTS, Alan. Taoísmo. El camino más allá del esfuerzo. Barcelona: Kairós, 1999.

WILLIAMS, Raymond: La larga revolución. Trad. de Horacio Pons. Bs. As., Nueva Visión, 2003

YACCAR, María. "Las canciones que quisieron desaparecer". Página 12, Buenos Aires, 25/03/2015. https://www.pagina12.com.ar/diario/elpais/1-268920-2015-03-25.html

ZARIELLO, Martín. "Música de fondo para el año 1974”. No blog próprio El Corvino, post de 2008, disponível em http://ilcorvino.blogspot.com.br/2008/03/msica-de-fondopara-el-ao-1974.html

ZOPPI FONTANA, Mônica. "A arte de cair fora. O lugar do terceiro na enunciação." Ecos, n. 2, 2004, p 59-69. 
